

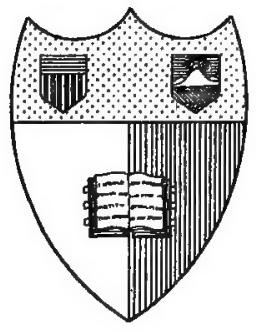

\section{A̛w Haxk \\ State Oallege of Agrinulture}

At Garnell Jlninersity

Jthara, N. 종.

\section{Iithrary}




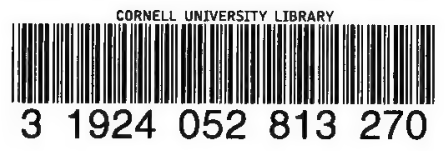




\section{Cornell University Library}

The original of this book is in the Cornell University Library.

There are no known copyright restrictions in the United States on the use of the text. 


\section{PROCEEDINGS}

OF THE

\section{American Forest Congress}

Held at Washington, D. C., January 2 to 6, 1905 , under the auspices of the

\section{AMERICAN FORESTRY ASSOCIATION}

Published for the Association

by the

H. M. SUTER PUBLISHING COMPANY

WASHINGTON, D. C. 



\section{PREFACE}

The American Forest Congress, the proceedings of which make up this volume, was held at Washington, D. C., January 2 to 6 , 1905, under the auspices of the

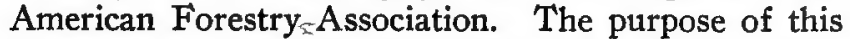
Congress, as stated in the official call, was "to establish a broader understanding of the forest in its relation to the great industries depending upon it; to advance the conservative use of forest resources for both the present and future need of these industries; to stimulate and unite all efforts to perpetuate the forest as a permanent resource of the nation."

That the time was ripe for such a meeting was proven by the splendid attendance, both in numbers and personnel, from every section of the country. From its inception the plan for the Congress had the approval of the President of the United States, as well as many of the most prominent persons in the official and industrial life of the country. As a result the American Forest Congress turned out to be not only the most important meeting ever devoted to forestry in the United States, but one of the most influential gatherings that has given its attention to an economic subject. It is not too much to say that from the date of this Congress forestry has come to have a new meaning to the American people.

It was the wish of the delegates that, in view of the very comprehensive treatment of the subject of forestry at the several sessions of the Congress, that the proceedings should be collected in permanent form, which explains the making of this volume. The plan fol- 
lowed in its compilation has not been to produce a verbatim report of the several sessions of the Congress, but to collect the full list of papers read and the more important impromptu addresses into convenient form for reading and ready reference. 


\title{
ORGANIZATION OF THE CONGRESS
}

\author{
gtonoraty presioent, \\ THE PRESIDENT OF THE UNITED STATES
}

Dresident of the Congress,

HON. JAMES WILSON

\section{Committee of Arrangements,}

JAMES WILSON,

Secretary of Agriculture.

A. J. CAgSATT,

President, Pennsylvania Railroad.

How ARD ELLIOTT,

President, Northern Pacific Ry.

JoHN HAYS HAMMOND,

Mining Engineer.

T. J. GRIER,

Supt. Homestake Mining Co., Lead, S. Dak.

FRED WEY ERHAEUSER,

St. Paul, Minn.

N. W. MaLEOD,

President, Nat'l Lumber Manufacturers Association.

V. H. BECKMAN,

Editor, Paeific Lumber Trade Journat.

R. A. LONG,

President, Southern Lumber Manufacturers Association.

GEORGE K. SMITH,

Secretary, Nat'1 Lumber Manufacturers Association.

GARRET SCHENCK,

President, Great Northern Paper Co.

ThoMAS F. WALSH,

President National Irrigation Association.

H. B. F. MACFARLAND,

President, Board of District Commissioners.

W. 8. HARVEY,

Vice - President, Pennsylvania Forestry Association.

JOHN JOY EDSON,

President, Washington Loan \& Trust Co.
ALBERT SHAW, Editor, Review of Reviews.

WHITRLAW REID, Publisher, New York Tribune.

REDFIELD PROCTOR,

United States Senator from Vermont.

HENRY C. HANSB ROUGH,

United States Senator from North Dakota.

Nathan B. ScotT,

United States Senator from West Virginia.

Thomas R, BARD,

United States Senator from California.

JaMES W. WADSWORTH,

Member of Congress from New York.

JOHN F. LACEY,

Member of Congress from Iowa.

FRANK W. MONDELL,

Member of Congress from Wyoming.

Charles D. WalcotT,

Director, U. S. Geological Survey. Gifford PINChot,

Forester, U, S. Department of Agriculture.

F. H. NEWELL,

Chief Engineer, U. S. Reclamation Service.

George H. Maxwell,

Executive Chairman, The National Irrigation Association.

B. L. WIGGINS,

Vice-Chancellor, University of the South.

GroRge P. WhITtLESEY,

Director, American Forestry Association. 
F. J. HAGENBARTH

President, National Live Stock Association.

\section{JESge SMITH,}

President, Utah Wool Growers' Association.

H. A. JAsTro,

General Supt., Kern CountyLand Co., Californin.

E. S. GosNEY,

Manager, Gosney \& Perkins Bank, Flagstaff, Ariz.

W. A. RICHARDS, Commissioner, General Land office.

B. T. GALLOWAY, Chief, Bureau of Plant Industry. Overton W. Prich,

Associate Forester, Bureau of Forestry.
H. S. GRAVEs,

Director, Yale Forest Bchool.

Filibert Roth,

Director, Forestry Department University of Michigan.

F. V. COVILLE,

Botanist, U. 8. Department of Agriculture.

WM. L. HaLL, Ass't Forester, Bureau of Forestry

JAMES B, ADAMS,

In charge of Records, Bureau of Forestry.

HERMANN VON SCHRENK, Expert, Bureau of Forestry.

H. M. SUTER, Editor, Forestry and Irrigation.

C. J. BLANGHARD,

Statistician, U. S. Reclamation Service. 


\section{CONTENTS.}

\section{PART I. \\ FORESTRY AS A NATIONAL, QUESTION}

The Forest in the Life of a Nation.............. 3 President Roosevelt.

The General Need of Forest Preservation........... I 3

James Wilson, Secretary of Agriculture.

The Forest PolitCY of France................... 22

J. J. Jusserand, Ambassador from France.

AtTITUDE, OF EDUCATtonal, Institutions Toward Forestru

B. L. Wiggins, Vice-Chancellor, University of the South.

IMPORTANCE OF THE FoRESTS to AgricUlTURE, ........ 42

John Lamb, Member of Congress from Virginia.

DEPENDENCE OF BUSINESS INTERESTS UPON THE FORESTS. 5 I

Howard Elliott, President, Northern Pacific Railroad.

PAR'T II.

IMPORTANCE OF THE PUBLIC FOREST LANDS TO IRRIGATION.

The Close Relation Betwein Forestro and Irrigation 53 Guy E. Mitchell.

FoRESTS AND RESERVOIRS....................... 60

F. H. Newell.

RELATTON OF FoREST COVER TO STREAMFLOW........... 67

J. B. Lippincott.

Rights of WAy IN Forest Restrits.............. 8i Morris Bien. 
viii

Irrigation Construction and Timber Supplites....... 87 Arthur P. Davis.

IMPROMPTU ADDRESSES :

H. M. Wilson.................. gr

J. W. Toumey....................... 93

PART III.

THE LUMBER INDUSTRY AND THE FORESTS.

THE LUMBERMAN'S INTEREST IN ForESTRY........... 99 N. W. McLeod.

Changed AtTitude of Lumbermen Toward Forestroy.... IO 3 J. E. Defebaugh.

Is Forestry Practicabie on Long Leaf Pine Lands?... I I24 John L. Kaul.

Is Forestry Practicable in the North west?........ 132

Victor H. Beckman.

INTEREST OF L,UMBERMEN IN CONSERVATIVE FORESTRY.... I I37 F. E. Weyerhaeuser.

IMPORTANCE, OF FORESTRY TO WOODWORKING INDUSTRIES... I42 M. C. Moore.

Is Forestry Practicable in the Northeast?....... I47 John A. Dix.

Our Pacific Coast Forists and Lumbiring as DifFikrING FROM OTHER FORESTS.............. I53 George P. Emerson.

Rise in Value of Stumpage............... I6 63

James T. Barber.

IMPORTANCE OF LUMBER STATISTICS.............. I66

George K. Smith.

OPPORTUNITIES For LuMBERING IN THE PHIL,IPPINES..... I73 George P. Ahern.

The Lumber Dealers' InTEREST IN Forest Preservation I89 George W. Hotchkiss.

Cooperage and Its Relation to Forestrky.......... I94 John A. McCann. 


\section{CONTENTS}

PART IV.

IMPORTANCE OF THE PUBLIC FOREST LANDS TO GRAZING.

Practical Results of the Régulation of Grazing in THE FOREST RESERVES.................. 210

A. F. Potter.

The Protection of Home Builders in The Regulation of

Grazing on Forest RESERVES............. 218 E. S. Gosney.

The Advantage of Coöperation Between the GovernoMENT AND THE LIVE STOCK AssociaTtons IN THE

Regulation and Control, of Grazing....... 228

Fred P. Johnson.

NECESSITY OF USING THE Forest RESERVES F'OR GRAZING

PuRPoseis............................ 232

Francis E. Warren.

Sheip Grazing in the Forest Reserves, From a LayMAN'S StANDPOINT..................... 242

L. H. Pammel.

IMPROMPTU ADDRESS.

R. H. Campbell.

\section{PART V.}

RAILROADS IN RELATION TO THE FOREST.

What Information is Most Urgently NeEded by RailROADS REGARDING TIMBER RESOURCES......... 253 Charles F. Manderson.

Work of the Peinnsyluanta Railroad in Planting TimbER For CROSS TIES.................... 260

Joseph T. Richards.

Is it Practicable for RaILROAds to Hold Forist LaNdS FOR FUTURE SUPPLIES OF TMMBER? ............ 265 I. E. Johnson. 
Results in the Preservative Treatment of RaIl Timbers to Prolong Durabilitit.......... 276 Herman von Schrenk.

LETTER EROM Mr. JAMES J. HILL. .............. 290

\section{PART VI.}

IMPORTANCE, OF PUBLIC FOREST LANDS TO MINING.

The DeVELOPMENT OF WATER POWER AS RELATED TO Forest Reserves................... 293 A. L. Fellows.

WILI, THE ADMINISTRATION OF THE ForEST RESERVES ON a Conservative Basis Retard the DeigelopMENT OF Mining?................ 302 Seth Bullock.

Importance OF THE PUblic Forest Lands to Mining. . . 307 T. J. Grier.

Mining in the Forest Reserves.............. 318 F. A. Fenn.

The Valui of Forestry to Commercial Interests. . . . 332 George H. Maxwell.

IMPROMPTU ADDRESS. 349

David T. Day.

PART VII.

NATIONAL, AND STATE, FOREST POLICY.

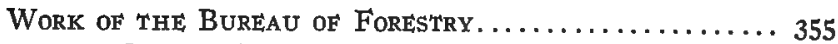

Overton W. Price.

Work OF THE Gelogical SURVEY IN Mappine THE

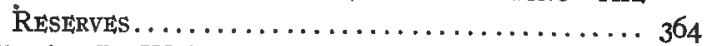

Charles D. Walcott.

Work of the General, Land OfFice in the AdministraTION OF THE RESERVES............... 38 I W. A. Richards. 


\section{CONTENTS}

A FEDERAL ForEST SERVICE.

Gifford Pinchot.

Progress in Forest Reservation in Pennsylvania..... 396

J. T. Rothrock.'

IMPROMPTU ADDRESSES :

John Lacy.......................... 403

W. A. Reeder........................ 409

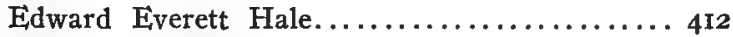

W. S. Harvey........................ 413

Aubrey White........................ 419

B, E. Fernow....................... 424

Mrs. L. P. Williams.................... 428

Filibert Roth...........................435

C. A. Schenck........................ 437

Rutherford P. Hayes..................... 439

Elihu Stewart........................ $44^{2}$

G. O. Shields........................ 444

Charles I. Pack........................ 446

RESOLUTIONS............................... 448

LIST OF DELEGATES......................... 454

AnNouncement of American Forestry Association.... 473 



\section{PART I.}

FORESTRY AS A NATIONAL QUESTION. 



\section{THE FOREST IN THE LIFE OF A NATION}

\section{BY \\ PRESIDENT ROOSEVELT}

IT IS a pleasure to greet all of you here this afternoon, but, of course, especially the members of the American Forest Congress. You have made, by your coming, a meeting which is without parallel in the history of forestry. And, Mr. Secretary, I must take this opportunity of saying to you what you so amply deserve, that no man in this country has done so much as you have done in the last eight years to make it possible to take a business view from the standpoint of all the country of just such questions as this. It is not many years since such a meeting as this would have been regarded as chimerical; the thought of it would have been regarded as absolutely chimerical. In the old pioneer days the American had but one thought about a tree, and that was to cut it down; and the mental attitude of the nation toward the forests was largely conditioned upon the fact that the life work of the earlier generations of our people had been of necessity to hew down the forests, for they had to make clearings on which to live; and it was not until half a century of our national life had passed that any considerable body of American citizens began to live under conditions where the tree ceased to be something to be cleared off the earth. 
It always takes time to get the mind of a people accustomed to any change in conditions, and it took a long time to get the mind of our people, as a whole, accustomed to the fact that they had to alter their attitude toward the forests. For the first time the great business and the forest interests of the nation have joined together, through delegates altogether worthy of the organizations they represent, to consider their individaul and their common interests in the forest. This Congress may well be called a meeting of forest users, for that the users of the forest come together to consider how best to combine use with preservation is the significant fact of the meeting, the fact full of powerful promise for the forests of the future.

The producers, the manufacturers, and the great common carriers of the nation had long failed to realize their true and vital relation to the great forests of the United States, and the forests and industries both suffered from that failure. The suffering of the industries in such case comes after the destruction of the forests, but it is just as inevitable as that destruction. If the forest is destroyed it is only a question of a relatively short time before the business interests suffer in consequence. All of you know that there is opportunity in any new country for the development of the type of temporary inhabitant whose idea is to skin the country and go somewhere else. You all know, and especially those of you from the West, the individual whose idea of developing the country is to cut every stick of timber off of it and then leave a barren desert for the homemaker who comes in after him. That man is a curse and not a blessing to the country. The prop of the country must be the business man who intends so to run his 
business that it will be profitable for his children after him. That is the type of business that it is worth while to develop. The time of indifference and misunderstanding has gone by.

Your coming is a very great step toward the solution of the forest problem-a problem which cannot be settled until it is settled right. And it cannot be settled right until the forces which bring that settlement about come, not from the Government, not even from the newspapers and from public sentiment in general, but from the active, intelligent, and effective interest of the men to whom the forest is important from the business point of view, because they use it and its product, and whose interest is therefore concrete instead of general and diffuse. I do not in the least underrate the power of an awakened public opinion; but in the final test it will be the attitude of the industries of the country which more than anything else will determine whether or not our forests are to be preserved. It is because of their recognition of that prime material fact that so much has been accomplished, Mr. Wilson, by those interested under you and in the other departments of the Government in the preservation of the forests. We want the active and zealous help of every man farsighted enough to realize the importance from the standpoint of the nation's welfare in the future of preserving the forests; but that help by itself will not avail. It will not even be the main factor in bringing about the result toward which we are striving; the main factor must come from the intelligence of the business interests concerned, so that the manufacturer, the railway man, the miner, the lumberman, the dealer in lumber, shall appreciate that it is of direct interest to them to preserve through use instead of waste the great resources upon which 
they depend for the successful development of their business. This is true because by far the greater part of all our forests must pass into the hands of forest users, whether directly or through the Government, which will continue to hold some of them but only as trustee. The forest is for use, and its users will decide its future. It was only a few years ago that the practical lumberman felt that the forest expert was a man who wished to see the forests preserved as bric-abrac, and the American business man was not prepared to do much from the bric-a-brac standpoint. Now I think we have got a working agreement between the forester and the business man whose business is the use of the forest. We have got them to come together with the understanding that they must work for a common end-work to see the forest preserved for use. The great significance of this Congress comes from the fact that henceforth the movement for the conservative use of the forest is to come mainly from within, not from without; from the men who are actively interested in the use of the forest in one way or another, even more than from those whose interest is philanthropic and general. The difference means, as the difference in such a case always does mean, to a large extent the difference between mere agitation and actual execution, between the hope of accomplishment and the thing done. We believe that at last forces have been set in motion which will convert the once distant prospect of the conservation of the forest by wise use into the practical accomplishment of that great end ; and of this most hopeful and significant fact the coming together of this Congress is the sufficient proof.

I shall not pretend this afternoon to even describe to you the place of the forest in the life of any nation, 
and especially of its place in the United States. The great industries of agriculture, transportation, mining, grazing, and, of course, lumbering, are each one of them vitally and immediately dependent upon wood, water, or grass from the forest. The manufacturing industries, whether or not wood enters directly into their finished product, are scarcely, if at all, less dependent upon the forest than those whose connection with it is obvious and direct. Wood is an indispensable part of the material structure upon which civilization rests; and it is to be remembered always that the immense increase of the use of iron and substitutes for wood in many structures, while it has meant a relative decrease in the amount of wood used, has been accompanied by an absolute increase in the amount of wood used. More wood is used than ever before in our history; Thus, the consumption of wood in shipbuilding is far larger than it was before the discovery of the art of building iron ships, because vastly more ships are built. Larger supplies of building lumber are required, directly or indirectly, for use in the construction of the brick and steel and stone structures of great modern cities than were consumed by the comparatively few and comparatively small wooden buildings in the earlier stages of these same cities. It is as sure as anything can be that we will see in the future a steadily increasing demand for wood in our manufacturing industries.

There is one point I want to speak about in addition to the uses of the forest to which I have already alluded. Those of us who have lived on the great plains, who are acquainted with the conditions in parts of Oklahoma, Nebraska, Kansas, and the Dakotas, know that wood forms an immensely portentous element in helping the farmer on these plains battle 
against his worst enemy - wind. The use of forests as windbreaks out on the plains, where the tree does not grow unless men help it, is of enormous importance, and, Mr. Wilson, among the many services performed by the public-spirited statesman who once occupied the position that you now hold, none was greater than what the late Secretary of Agriculture, Mr. Morton, did in teaching, by actual example as well as by precept, the people of the treeless regions the immense advantage of the cultivation of trees. When wood, dead or alive, is demanded in so many ways, and when this demand will undoubtedly increase, it is a fair question, then, whether the vast demands of the future upon our forests are likely to be met. You are mighty poor Americans if your care for the well-being of this country is limited to hoping that that well-being will last out your own generation. No man, here or elsewhere, is entitled to call himself a decent citizen if he does not try to do his part toward seeing that our national policies are shaped for the advantage of our children and our children's children. Our country, we have faith to believe, is only at the beginning of its growth. Unless the forests of the United States can be made ready to meet the vast demands which this growth will inevitably bring, commercial disaster, that means disaster to the whole country, is inevitable. The railroads must have ties, and the general opinion is that no efficient substitute for wood for this purpose has been devised. The miner must have timber or he cannot operate his mine, and in very many cases the profit which mining yields is directly proportionate to the cost of timber supply. The farmer, east and west, must have timber for numberless uses on his farm, and he must be protected, by forest cover upon the head- 
waters of the streams he uses, against floods in the East and the lack of water for irrigation in the West. The stockman must have fence posts, and very often he must have summer range for his stock in the national forest reserves. In a word, both the production of the great staples upon which our prosperity depends, and their movement in commerce throughout the United States, are inseparably dependent upon the existence of permanent and suitable supplies from the forest at a reasonable cost.

If the present rate of forest destruction is allowed to continue, with nothing to offset it, a timber famine in the future is inevitable. Fire, wasteful and destructive forms of lumbering, and the legitimate use, taken together, are destroying our forest resources far more rapidly than they are being replaced. It is difficult to imagine what such a timber famine would mean to our resources. And the period of recovery from the injuries which a timber famine would entail would be measured by the slow. growth of the trees themselves. Remember, that you can prevent such a timber famine occurring by wise action taken in time, but once the famine occurs there is no possible way of hurrying the growth of the trees necessary to relieve it. You have got to act in time or else the nation would have to submit to prolonged suffering after it had become too late for forethought to avail. Fortunately, the remedy is a simple one, and your presence here to-day is a most encouraging sign that there will be such forethought. It is the great merit of the Department of Agriculture in the forest work that its efforts have been directed to enlist the sympathy and coöperation. of the users of wood, water, and grass, and to show that forestry will and does pay, rather than to exhaust itself in the futile attempt to introduce conservative 
methods by any other means. I believe most emphatically in sentiment, but I want the sentiment to be put into coopperation with the business interests, and that is what is being done. The policy is one of helpfulness throughout, and never of hostility or coercion toward any legitimate interest whatever. In the very nature of things it can make little progress apart from you. Whatever it may be possible for the Government to accomplish, its work must ultimately fail unless your interest and support give it permanence and power. It is only as the producing and commercial interests of the country come to realize that they need to have trees growing up in the forest no less than they need the product of the trees cut down, that we may hope to see the permanent prosperity of both safely secured.

This statement is true not only as to forests in private ownership, but as to the national forests as well. Unless the men from the West believe in forest preservation the western forests cannot be preserved. We here at the headquarters of the National Government recognize that absolutely. We believe, we know, that it is essential for the well-being of the people of the states of the great plains, the states of the Rockies, the states of the Pacific slope, that the forests shall be preserved, and we know also that our belief will count for nothing unless the people of those states themselves wish to preserve the forests. If they do we can help materially; we can direct their efforts, but we cannot save the forests unless they wish them to be saved.

I ask, with all the intensity that I am capable, that the men of the West will remember the sharp distinction I have just drawn between the man who skins the land and the man who develops the country. I am going to work with; and only with, the man who develops the country. I am against the 
land skinner every time. Our policy is consistent to give to every portion of the public domain its highest possible amount of use, and, of course, that can be given only through the hearty coöperation of the western people.

I would like to add one word as to the creation of a national forest service which $I$ have recommended repeatedly in messages to Congress, and especially in my last. I wish to see all the forest work of the Government concentrated in the Department of Agriculture. It is folly to scatter such work, as I have said over and over again, and the policy which this administration is trying to carry out through the creation of such a service is that of making the national forests more actively and more permanently useful to the people of the West, and I am heartily glad to know that the western sentiment supports more and more vigorously the policy of setting aside national forests, the creation of a national forest service, and especially the policy of increasing the permanent usefulness of these forest lands to all who come in contact with them. With what is rapidly getting to be a practically unbroken sentiment in the West behind such a forest policy, with what is rapidly getting to be a practically unbroken support by the great staple interests behind the general policy of the conservative use of the forests, we have a right to feel that we have entered on an era of great and lasting progress. Only entered upon it; much, very much, remains to be done; and as in every other department of human activity our debt of gratitude will be due, not to the amiable but shortsighted optimist who thinks you have made a good beginning and the end may take care of itself; still less to the man who sits at one side and says how poorly the work is being done by those who are doing 
it; but to the men who try, each in his own place, practically to forward this great work. That is the type of man who is going to do the work, and it is because I believe that we have enlisted the active, practical sympathy of just that kind of man in this work that I believe the future of this policy to be bright and the permanence of our timber supplies more nearly assured than at any previous time in our history. To the men represented in this Congress this great result is primarily due.

In closing I wish to thank you who are here, not merely for what you are doing in this particular movement, but for the fact that you are illustrating what I hope I may call the typically American method of meeting questions of great and vital importance to the nation - the method of seeing whether the individuals particularly concerned cannot by getting together and coöperating with the Government do infinitely more for themselves than it would be possible for any government under the sun to do for them. I believe in the future of this movement, because I think you have the right combination of qualities - the quality of individual initiative, the quality of individual resourcefulness, combined with the quality that enables you to come together for mutual help, and having so come to work with the Government; and I pledge you in the fullest measure the support of the Government in what you are doing. 


\title{
THE GENERAL NEED OF FOREST PRESERVATION
}

\author{
BY \\ JAMES WILSON
}

Secretary of Agriculture and President of the American Forest Congress

I MAKE you welcome to the Federal seat of Government, to consider the state of our forests, and of our lands that cry aloud for want of trees and the peculiar forest conditions that cannot exist without their presence.

Forestry is not a local question. It is as wide as American jurisdiction. It is not a class question; it affects everybody. It is not limited by latitude or longitude, by State lines or thermal lines, by rivers or mountain ranges, by seas or lakes.

Steel has taken the place of wood for fencing to a large extent. It has taken the place of wood for ships to some extent, it is being introduced in house-building, and is replacing wood extensively in the making of machinery and for other purposes. Coal and gas are taking the place of wood as fuel, and cement is taking its place for building. The use of wood, notwithstanding these substitutes, increases every year and our forests steadily vanish before the axeman.

The extension of railroads, the settlement of the public domain, the building of cities, towns and villages, the use of wood in paper-making and the opening of mines, call for more wood every year, and the forests respond to the demand. There are but a few large reserves left from which to draw supplies. The extreme east, the extreme west, and the Gulf coast are now sources of commercial supply. The industries 
of our country will be carried on at greater expense as wood becomes scarcer and its substitutes become dearer. Agriculture, commerce and mining will greatly miss the cheap supply of wood to which they have been accustomed.

The nation is awakening to the necessity of planting trees and making the most of those that are mature. Our institutions of learning are taking up the study of forestry. State societies are inquiring. The experiment stations of the several States and Territories are making research. The Department of Agriculture is training a Bureau of forest experts in woodcraft to serve the nation, the States, companies and individuals along forestry lines.

There are hopeful forestry signs:

A disposition among lumber companies to hold cutover lands, protect them from fire, encourage a new growth, and harvest the young forest, requires the establishment of forestry schools in colleges and universities where the science of forestry is being taught in the light of experience.

The employment of foresters by large private owners, who find that educated supervision is a prime necessity.

Reforesting of large areas is being carried on by the Bureau of Forestry and by several States, for the purpose of giving object lessons to our people with regard to methods of planting and varieties of trees. The farmer is inquiring and planting for wind-breaks, fuel, and in many cases he is planting valuable varieties for coming generations.

Scientific study is preparing a reliable foundation for practical forestry, with regard to the principles that govern the life of trees in different conditions of soil and climate.

Coöperation between the Department of Agriculture 
and the States, and with companies and individuals, is progressing rapidly. Our trained foresters are getting into touch with the college and experiment station forces of the States, with companies that hold woodland for present and future use, and with individuals.

The Congress is giving liberally to forest research, enabling us to do systematic work with wood in all its uses.

The future requires planting in the uplands, at the sources of all our streams, that should never be denuded, to make the hills store water against times of drouth and to modify the flooding of the lowlands. We have to tell the people of the lower Mississippi every few years to raise their levees to hold the floods that exceed themselves as the forest ceases to hold waters that in previous years were directed into the hills and held back.

Every tree is beautiful, every grove is pleasant, and every forest is grand; the planting and care of trees is exhilarating and a pledge of faith in the future; but these rsthetic features, though elevating, are incidental; the people need wood. They have had it in abundance and have been prodigal in its use, as we are too often careless of blessings that seem to have no end. Our history, poetry and romance are intimately associated with the woods. Our industries have developed more rapidly because we have had plenty of cheap timber. Millions of acres of bare hillsides, that produce nothing profitably, should be growing trees.

We are beginning a meeting which is national in its significance. Never before in this country, nor so far I know in any other country, has a body of men representing such great and varied interests come together to discuss, temperately and foresightedly, the policy and the methods under which the highest per- 
manent usefulness of the forest can be maintained. That we, men as varied in our occupations as are the industries and interests we represent, are drawn together by this common cause, may well mark the beginning of a new era in our treatment of the forest. Your presence here is itself the best possible proof that forestry is rapidly taking its appropriate place as an active and indispensable factor in the national economy. The era of forest agitation alone has entirely passed. We are talking less and doing more. The forest problem, as President Roosevelt has described it, is recognized as the most vital internal problem in the United States, and we are at work upon it.

Free discussion here will aid greatly towards the best solution of this problem. Above all, this Congress affords us an opportunity to formulate a forest policy broad enough to cover all minor points of difference, but definite and clear cut enough to give force and direction to the great movement behind it. In the very nature of things, these minor points of difference will continue to exist; and this is necessary for the highest effectiveness of our forest work in the long run. But we are facing a problem which can be met squarely only by vigorous and united action.

I look for excellent results from the deliberations of this Congress, for more light upon vexed questions, and for the statement of new and useful points of view. But above all, I hope from our meeting here there will come a more complete awakening to the vastness of our common interest in the forest, a wider understanding of the great problem before us, and a still more active and more earnest spirit of coöperation.

Because of your individual achievement in your chosen fields this is a great gathering and a most 
effective one. It is upon you and others like you that the future of our forests mainly depends. Unless you, who represent the business interests of the country, take hold and help, forestry can be nothing but an exotic, a purely Government enterprise, outside our industrial life, and insignificant in its influence upon the life of the nation. With your help, it will become, and is becoming, one of the greater powers for good. Without forestry, the permanent prosperity of the industries you represent is impossible, because a permanent supply of wood and water can come only from the wise use of the forest, and in no other way, and that supply you must have.

I am glad to see the irrigation interests so strongly represented here, because forestry and irrigation go hand in hand in the agricultural development of the West. The West must have water, and that in a sure and permanent supply. Unless the forests at the headwaters of the streams used in irrigation are protected, that is impossible, and irrigation will fail. Unless we practice forestry in the mountain forests of the West, the expenditure under the national irrigation law will be fruitless, and the wise policy of the Government in the-agricultural development of the arid regions will utterly fail. Without forestry, national irrigation will be merely a national mistake. The relation in the arid regions between the area under forest and the area in farms will always be constant. We can maintain the present water supply of the West by the protection of existing forests. In exactly the same way, we can increase this supply by the foresting of denuded watersheds. The full development of the irrigation policy requires more than the protection of existing forests-it demands their extension also. 
In the value of its invested capital and its product, lumbering ranks fourth among our great industries. But in its relation to the forest it stands first. To bring the lumberman and the forester together has been the earnest and constant endeavor of the Department of Agriculture. Ten years ago, or even five years ago, we did not fully understand each other. To-day, in every great forest region in the United States, lumbermen and foresters are working together in active, hearty, and effective coöperation on the same ground.

It is true that the area under conservative forest management is still small, but the leaven is working and the inauguration of new, more conservative, and better paying methods has fully begun. What the general adoption of conservative lumbering will mean to the individual lumberman, to the lumber industry, and to the country as a whole, is beyond estimate. And it is coming, because it will pay.

The vast area of the timber lands of the United States is mainly in your hands. You have it in your power, by putting forestry into effect upon the lands you own and control, to make the lumber industry permanent, and you will lose nothing. by it. If you do not, then the lumber industry will go the way of the buffalo and the placer mines of the Sierra Nevada. But I anticipate no such result. For the fact is that practical forestry is being adopted by American lumbermen. In its results it will surpass the forestry practiced in any other country. The development of practical forestry for the private owner has been more rapid here than in any other country, and I look for a final achievement better than any that has been reached elsewhere.

The regulation of grazing upon the public forest 
lands is a forest question, and like all other national forest questions its settlement should always be for the best interests of the people most deeply interested. Forest reserves are essential to the permanent productiveness of that portion of the public range which they enclose. The question of grazing has from the beginning been the chief problem in the management of the forest reserves. The principles which control the conservative use of the public range are identical with those which control the conservative use of the public forests. The objects are a constant supply of wood and water on the one hand and of forage on the other. Just as the saw mills must eventually shut down unless forestry is applied to the forest from which the saw logs come, so the horses, the cattle, and the sheep of the West must decrease both in quality and number, unless the range lands of the arid region are wisely used. Over-grazing is just as fatal to the live stock industry as destructive logging is to the lumber industry. The highest returns from the forest can be had only through recognizing it as invested capital, capable, under wise management, of a steady and increasing yield, and the permanent carrying power of the range can be maintained or increased only by the wise regulation of grazing.

The relation of railroads to the forest is no less vital than that of the lumberman. The development of systems of transportation upon a secure basis depends directly upon the preservation and wise use of the forest. Without a permanent supply of wood and water, the business of the railroads will decline, because those industries upon whose production that business mainly depends cannot prosper. But the railroads are interested in a still more vital way. As great and increasing consumers of wood for ties, con- 
struction timbers, poles, and cars, they are in direct and urgent need of permanent sources of these supplies. The problem directly before the railroads is, therefore, the forest problem in all its parts. Much may be done by the preservative treatment of ties and railroad timbers, which not only prolongs their life, but also leads to the profitable use of wood of inferior kinds and a corresponding decrease in the drain upon the forest and the cost of its product. But, important as this is, it merely mitigates the danger instead of removing it. For their own protection the railroads must see to it that the supply of ties and timbers in the forest itself is renewed and not destroyed.

The importance of the public forest lands to mining is direct and intimate. Mines cannot be developed without wood any more than arid lands can become productive without water. The public forest lands are, and must continue to be, the chief source of timbers used in our western mines. The national forest reserves are thus vital in their relation to mining; and where mining is the chief industry, their resources should be jealously guarded against other and less productive use. Forest reserves impose no hampering restrictions upon the development of mineral wealth, either within their borders or their neighborhood, and they alone can give the western mining industry a permanent supply of wood, and so assure its safety now and its largest development in the future.

I am particularly glad that this Congress will include a full discussion of national and State forest policy. The forest movement in several States has already resulted in the adoption of definite State forest policies. In many others, the time is ripe for useful work because of the existence of a strong sentiment for the best use of the forest. The forest problems 


\section{AMERICAN FOREST CONGRESS}

in different States cannot all be solved in exactly the same way. The methods will in each case have to be worked out on the ground where they will be used. But we have before us here the same opportunity in State forest matters as in other phases of the forest problem, for full discussion of methods and results. Above all we must find the most effective means of working together towards the same great ends. 


\title{
THE FOREST POLICY OF FRANCE.
}

\author{
BY

\section{Mr. J. J. JUSSERAND}

Ambassador from France

I AM very happy to be enabled, by the flattering invitation of the Hon. Secretary of Agriculture, to add French congratulations to the American congratulations and American advice which this Congress has just received from the most popular and most eloquent voice in the United States.

The subject of your studies is one indeed which appeals most powerfully to man's mind, not to say man's heart. The forest is the great friennd which supplied the early wants of mankind, giving the first fuel, helping to the rearing of the first real house. And now, after the lapse of thousands of years, the forest continues the great friend, so adaptable it is to our wants. The more we invent, the greater become our new needs, and the more necessary is the forest for us. Railroads are called in French "chemins de fer," but for all the iron in them, where would we be without the forest? It supplies the dozen million cubic meters of wood spent every year in the world for railways.

The forest has one singular and providential advantage over most of the earth-produced elements of our industries. When we have exhausted an iron mine, a gold mine, an oil well, a supply of natural gas; when the oil has been carried in immense pipes from Chicago to New York and from thence to our private lamps, it is finished; we can consume the thing; we cannot make it. Not so with the forests. It is in our hands 
to improve or impair them, to kill them or to make them live. As to which of these fates is in store for American forests your presence here supplies a sufficient answer.

But is there need to do anything, or have we plenty of time to think of it? The country is immense, its resources prodigious. The nation is a young one; should not something be allowed to youth? Certainly, anything, except what might maim and cramp a splendid future.

That something is allowed, especially in the matter of forests, cannot be doubted. One of the first things which struck me, coming over to America, was how much was allowed. Going north, west or south, sights of the same sort met my eyes and my French eyes opened with surprise. Going to Saint Louis last year, I noticed large spaces where big trees had been cut, the stumps remaining as high as a man's shoulder. So much wood lost, I thought; so much land untillable because of those stumps remaining in place! Coming from Canada on another occasion the train was following a succession of what should have been beautiful valleys. But they were valleys of the shadow of death. The view was saddened by the corpses of innumerable trees which had been cut, for what cause I do not know; was it for their bark, or for something else? I could not surmise. But the fact was that they were there, crumbling to pieces, rotten and unavailable, spoiling the landscape, and making the soil useless by their thousands of dead bodies. Going to Louisiana, in another case, my heart bled truly at seeing the blue sky blackened by the smoke of forests in flames. This terrible mode of clearing the ground seems to be still in use; and I noticed places where the fire, being not violent enough, had not cleared the ground, but had 
ruined and killed the trees, so that it was havoc pure and simple.

All this, of course, are a foreigner's impressions, and perhaps they may be considered unreasonable. You are young and wealthy; you can afford to spend. You can afford to spend to-day, and to-day is certainly as bright as it can be. But, as you know, squandering habits, when once taken, are most difficult to check, at a moment's notice, just at the time wanted; and, as your eminent President remarked, the nation should think of to-morrow.

In France, we think much about to-morrows, because we have known so many yesterdays. Our case is very different. We have not your boundless resources; we must husband what we possess. Our land is limited, our mines of small importance; our fields have been furrowed by the plough for eighteen centuries more than yours; the accumulated public debts, left by past regimes or caused by present necessities, weigh on our shoulders; and yet with this weight, at this day, we stand, and, if I may believe what I hear reported, our friendship is still worth having, as well worth as it was ever in times past.

There is only one explanation: What we do, we try to do it with method; what we do, we do with care. We have no other secret.

There is nothing lost in France, nothing thrown away-not a rag, not a bit of bread, not a stick of wood. Many think we are a laughing, singing nation. If we were such, and nothing more, we should have long since disappeared. We are a living example that people may love to have their laugh and their song, and yet keep their forests in good order. Method and gloom do not go necessarily together.

That great philosopher, Bacon, who was no particu- 
lar friend of the French (he ended badly, you know), paid us, in one of his essays, this half-hearted compliment: "The French are wiser than they seem." Well, such as it is, I accept his saying; to have wisdom is the thing, and it little imports whether it is apparent or concealed. Roots are not visible, and you know, you foresters, that it is the root that feeds.

Our policy in the matter of forests is a time-honored one. Like the rest of the inhabitants of our land, they have their own code of laws, the "Code forestier," framed and issued in 1827 , itself, in its main lines, an adaptation of Colbert's famous ordinance of 1669 , which ordinance, in its turn, reproduced other laws, some dating back from the time of Charles-the-Wise, fourteenth century.

We were early struck by the necessity of preserving forests, and more and more so as we acquired a better knowledge of the use and wants of these friends of man. We have a National School of Forestry at Nancy, where the sound principles of forestry are taught. The practical importance of this teaching is testified to by so many foreign students whom we are happy to welcome there, some coming from America -one, an eminent one, whom I would name, if he was not so near me on this platform (Mr. Pinchot).

Our forests have not only a code, but an army of their own, an army of six thousand men, foresters, rangers and keepers - a real army, submitted to military discipline, so much so that in time of war this troop is transferred from the Ministry of Agriculture, where all the forestry services are centered, to the Department of War.

Several laws have been passed since the code was promulgated, not at all to relax its rules, but to make them more practical and efficient. In I860 a law was 
enacted making it obligatory for the owner of mountains or mountain slopes to reforest them if denuded. The application of this law is one of my earliest souvenirs. In 1860 , I was not very, very old, and I went often with my grandfather to see our Government-ordered plantation. The Government supplied the seed and we had to do all the rest. For years I went to see our trees, and I had difficulty in seeing them, they were so small. Now when I go, the trees can scarcely perceive me, they are so tall.

A new law was passed in I862, giving more liberty to the landowner. $\mathrm{He}$ is allowed to refuse to do the work. The Government has then the right to pay him a fair sum for his land and expel him and plant the trees, so important is it considered for the whole community. For the importance of such plantations is more and more apparent. We see destruction and poverty invade the parts where the rules have not been applied; wealth and comfort grow in those where the rules have been followed. Where there is a just proportion of forest ground the temperature is more equal, the yielding of water more regular, and, as President Rooseveit has so well shown a moment ago, forests have a most beneficent effect with regard to winds. Observations in the South of France have shown that, since the Esterel has been reforested, the destructions caused by that terrible wind called the mistral have diminished.

The seacoasts of France were being gradually invaded by the sand, and the wind carried this death powder further inland, as years passed on. In 1810, we tried forestry, and the forest showed itself, as usual, the friend of man. The sand country has entirely disappeared, as well on the Ocean as on the Channel, and the desolate regions of yore are now wealthy, 
pleasant ones, where people even flock for their recreation and their health.

The same careful and methodical policy is being introduced in our colonial dominions. There the difficulties are sometimes very great, because the havoc has been more complete. We try, for example, to reinduce trees to give back to Southern Tunis its pristine fertility. Most of it is now a sand desert. What it was in Roman times we know by the ruins and the inscriptions. The capital of the South, Suffetula, as it was called, consists now in scattered ruins in the midst of absolute desert. One of the inscriptions discovered contains a description given by an old Roman veteran of what his villa was. He had retired there after his campaigns, and describes the trees, the plots of grass, and the fluent waters which adorned his retreat-now buried under the shroud of the desert sand.

The Arab conquest destroyed all the trees there, and killed the forest. The punishment was not long to follow. No forest there. No men. Not long after the conquest, the mischief was already considerable, the land was desolate, and an Arab chronicler, seeing the havoc done, recalled in his book the former times of prosperity, adding: "But in those days, one could walk from Tripoli to Tunis in the shade."

I shall add only one word. There are, as you know full well, two great classes of forests, and no more. There is the wild forest and there is the civilized forest. People who know forests only through books-I mean through bad books, not the books written by members of this assembly-fancy that the wild forest is the thing. A time there was, too, when people thought that the wild man, the man in the state of nature, was a nest of virtues, and that, leading a kind of simple 
life, he led also, of necessity, a model life. The truth is quite different: Virtue, like all plants of price, needs cultivation; forests need the eye, the mind, and the heart of man. Instead of being full of the most beautiful and useful trees, the wild forest offers, by comparison, a prodigiously small quantity of good trees; many have outlived their period of use, and they prevent the growth of others; many have grown crooked; wicked ones have injured the righteous.

Now the question is, which sort of forest is to be favored here? It is a great thing for this country to know what your intentions are, and what you mean to do. In doing it, in fulfilling your duty as good foresters, it so happens that you will, at the same time, second what is uppermost in the mind of every good American-that is, to help, so far as is in you, to the spreading of civilization. 


\section{THE ATTITUDE OF EDUCATIONAL IN- STITUTIONS TOWARD FORESTRY}

\section{BY \\ B. LAWTON WIGGINS, LL. D.}

Vice-Chancellor, University of the South.

T HE attitude of at least one educational institution toward forestry will be best appreciated through the statement of the following few facts:

The University of the South has at Sewanee, Tennessee, what is perhaps the largest university campus in the world. It comprises 7,250 acres of land, of which 6,500 acres are wooded. In I898, Mr. Gifford Pinchot, Forester of the United States Department of Agriculture, inspected the university domain and made with the university one of the agreements which the Bureau of Forestry has for coöperating with timberland owners in the management of their tracts. To be acceptable to the university, the scheme of management had to provide for good net financial returns, for we are in the position of most small owners of timberland -unable to leave much merchantable timber in the woods or to reinvest much of our profit in forest improvements. To comply with the requirements of the Bureau of Forestry, the working plan had to provide for leaving the forest in better condition than before; in other words, the working plan had to cover the judicious selection of the trees to be cut, so as to favor the reproduction and growth of the desirable kinds, the avoidance of damage to small growth and of waste in cutting logs, and protection against fire, while at the same time assuring a profit to the university. 
And what has been the result? I recall quite distinctly that when a little while previously a lumberman offered $\$ 2,000$ for the major portion of our timber, there were those in authority who regarded that sum as a fair valuation. We began operations under the direction of foresters in 1900 , and have cut a little over two million board feet of logs, at a net profit of about $\$ 7,250$. Two years more of cutting-and profitremain. And the condition of the forest is satisfactory to the Bureau of Forestry, which finds that there are plenty of vigorous small trees over the logged area given a new lease of life owing to increased light and growing space, and that reproduction of the best kind has taken place, even little yellow poplars, white ashes, and white elms being found.

This has furnished an object lesson for our inmmediate neighbors and for representatives of the entire South, who visit our beautiful plateau in large numbers every summer. They can see and hear of results from the practice of conservative logging, and readily understand the attitude of the University of the South. It is a zealous missionary, preaching everywhere and at all times the gospel of forestry.

I speak to you this afternoon not as a trained professional forester, but as one whose interest in the proper management of timberland has been quickened and strengthened by the above-mentioned association with foresters. President Roosevelt has told us that the forest problem is in many ways the most vital internal problem in the United States; that "the United States is exhausting its forest supplies far more rapidly than they are being produced; that the situation is grave, and there is only one remedy; that that remedy is the introduction of practical forestry on a large scale, which is, of course, impossible without trained men, 
men trained in the closet and also by actual field work under practical conditions." The economic peril is coming to be realized everywhere- -less so in the South perhaps than in any other section, though even there the far-seeing men are now convinced that something should be done to prevent the diminution of water supplies, the occurrence of disastrous floods, and the almost inevitable and speedy exhaustion of the timber supply; and that for this purpose the trained hands and heads of several thousand men will be required to start and continue the work of improving our woods.

The calls for the assistance of the Bureau of Forestry indicate the demand for the services of trained men, and this constant and increasing need is bound to grow larger and more insistent each time a forester has a chance to create practical examples of his useful and necessary sphere in the welfare of the nation.

How are they to be supplied?

Europe has long since discovered the value and necessity of "forest schools," not only for turning out trained specialists in the art of forestry, but of diffusing among the people a general and genuine interest in forestry; for creating a healthful public sentiment, which constitutes the best possible protection for the woods; for leading men to regard forests as their friends and to understand their influence in staying spring torrents and preventing summer droughts, and their economic value in supplying lumber and fuel.

Recent federal and state legislation evidences a growing public sentiment in favor of forestry, but we must not fail to realize that all laws which are not supported by a general public sentiment are difficult of operation.

Ever since the founding of the American Forestry Association in 1882 the need of providing for educa- 
tion in forestry has been stressed more and more from year to year. Yet only six years ago Doctor Fernow spoke of the New York College of Forestry as "this novel institution." To the bounty of the State of New York the first professional college of forestry in the United States owed its existence, and to Cornell University belongs the credit of administering it. It began its first course, which covered four years of undergraduate work, in 1898 with five students. When it closed in I902, on account of the omission from the state appropriation bill of the clause providing funds for its maintenance owing to misguided and selfish opposition, it had forty-four students enrolled. All who completed their courses promptly secured good positions. In fact, the pressure for the services of educated foresters was so great that leaves of absence before graduation were allowed to some graduates, and one senior yielded to the temptation to accept a position before completing his course.

The Yale Forest School, opened in 1900, was the first graduate school of forestry organized in this country. To quote Professor Graves' own language: "The organization had in mind the needs of two classes of men required to carry on the work of forestry in the United States: First, thoroughly trained experts, who are competent to organize and administer the work in government, state, or private forests, or to pursue the necessary scientific study of our forests; and second, men with a general knowledge of forestry and special skill as woodsmen, qualified to act as rangers, inspectors, foremen, etc. The first class of men will be called upon to assist in the organization of the work of forestry on government, state, or private tracts; to direct legislation; to creat public sentiment in favor of forestry; to pursue the scientific 
study of our trees and forests; to solve the difficult problems of the influence of fire, grazing, and excessive lumbering on forests, as well as the problems connected with the protection of the head waters of rivers; and to carry on and direct the practical management of forests of every character and size. In order to do this work intelligently and successfully a thorough special training in forestry is required, in addition to a general education. The forest school has been made a graduate department, to which only college graduates are admitted without examination, in order to attract educated men to forestry and to produce men of the highest possible training for the work of developing the profession. The fact, however, was not overlooked that there is a class of work for which so thorough a training is required, and the summer school is especially designed to furnish instruction sufficiently comprehensive for this work."

Notwithstanding the high standing required for admission, the registration has increased from a beginning of five to sixty-three at present. The students have come from thirty-three of the United States and from the Philippines, Japan, South Africa, Canada, and Sweden. In one respect, says President Hadley, the Yale Forest School is a model to the other departments of the university, in that it is in active touch with the demands of practical life and the opportunities for employment therein. It gives the students of Yale an assurance that side by side with their training in general culture and public spirit, they are adapting themselves to speedy usefulness in the complex organization of modern commercial life.

The Biltmore Forest School opened in 1897, and is therefore the oldest in the United States. Although not connected with an established educational institu- 
tion, it has the great advantage of being located on Biltmore estate, where Mr. Pinchot introduced scientific forest management into the United States in I89I, which good work has been kept going by the able founder and director of the school, Doctor Schenck.

The two years of graduate forest work afforded by the University of Michigan began in 1903, and the department has grown in every way.

Harvard, Maine, Minnesota, and Nebraska universities, and Iowa State College of Agriculture and Mechanical Arts have departments of forestry. Most of the agricultural colleges offer some instruction in forestry in connection with the courses in botany, horticulture, or the like.

In several cases high schools are following the lead of the universities, and more would doubtless do so if the teachers were properly equipped. The Secretary of Agriculture declares that the rapid increase of interest in forestry throughout the country is nowhere more noticeable than in educational circles.

Such is the attitude of many of our educational institutions toward forestry, and yet only a short time ago I heard it argued that instruction in forestry should be given in isolated, independent schools; that it should constitute no part of a university course. Continental Europe settled that question more than a quarter of a century ago, when, says Mr. B. G. Northrup, "a congress of foresters, which was at Freiburg and attended by nearly four hundred members, representing all parts of Germany, Switzerland, Austria, and Russia, after a long and spirited discussion by prominent professors from both classes of forest schools, decided by an almost unanimous vote (only sixteen dissenting) in favor of combining instruction in forestry with other departments in the university; 
and this leads me to the question, "What should be the attitude of our universities toward forestry?"

Is not a university a place of universal search for universal truth? Let whoever is disposed to be impatient of the progress that is being made reflect upon the history of recent university development. We must look backward in order to look forward.

It was not until late in the last century that science received recognition, and provision was made for its teaching. When graduates of American colleges realized that they had failed to get what they needed for their life work and that there was a strong prejudice against the admission of applied sciences on a proper basis, they began to endow coördinate factulties, which continued for a long time as separate faculties, and are not even now completely assimiliated. It was some time also before pure science, which had been taught in a most elementary way, met with a suitable response -that chairs were established and equipments purchased. Who does not recall the crusade of science against philology and the conflict which was waged almost unremittingly for half a century or more between the advocates of classical and scientific study; the latter claiming that we must reconstruct our academic and university systems after the inspiration of modern ideas, and must substitute those studies which would be more efficient in their disciplinary value and more useful by reason of their.closer affinities with the practical tendencies of our modern scientific life; the former, while admitting freely the claims of science, maintaining that the classics were needed more than ever to resist the utilitarian and materialistic tendencies of the age, and that an education cannot be full-orbed and rounded off without the classics. Greek and Latin had been supreme for so many centuries that the physi- 
cal and natural sciences were not without a struggle admitted to equal rank.

This led to a readjustment of the long-established and closely articulated curriculum, which resulted finally in the adoption of the elective system. And this was the beginning of a recognition granted to what one might call the new learning-modern science, economics, political science, and the like, which proved, when properly taught, in no respect inferior to the subjects of the old curriculum, either in training the mind or preparing for future careers. The limitations of the traditional college education of the past, which was intended for only certain of the learned professions-law, medicine, and particularly theology-soon became apparent. The world was moving on. New constituences and new demands were arising, new problems were being projected on the economic and political horizons, new questions were pressing for answer. Must we not readjust our education forces to meet the needs of that large majority of men preparing to engage in banking, railways, insurance, trade and industry, forestry, diplomacy, journalism, and politics? Are not these several callings as important to the life of the nation as the traditional professions? State universities derive their support from the taxation of the whole people, representing in a large measure the fruits of the toil and self-denial-whether voluntary or enforced, whether direct or indirect-of the common people. Are they justified in spending so much money to furnish a certain kind of education for the benefit of a privileged class, where there is this growing demand for the diffusion of higher learning, for its much wider application to the daily life and institutions of the whole people?

Do not all professions and callings require, and will 
they not more and more require, thought and disciplinary training as well as technical training? Is it true, as Mr. Carnegie and Mr. Schwab have said, that the most efficient school of business is business? If so, ought it not be otherwise? We are told that President Thwing, who has been looking into the matter of salaries received by graduates of regular colleges and scientific schools, finds that in the long run the college graduates do the best; that scientific methods are supposed to fit men for immediate employment; that graduates of these schools seem to find employment somewhat more readily and at somewhat higher pay than the college graduate; but that the difference is not great even at first, and that after a few years the college graduate has the best of it. Only a few years ago a director of the Pennsylvania system of railroads remarked that in future promotions preference would be given college men-men who had been trained in the principles as well as in the practice of the profession, and who had acquired not only the technique, but also the capacity to think and to comprehend all the problems which might arise. For, as Mr. Laughlin expressed it, "While a school of mechanical engineering is required to fit a man for the practical parts of railroading, there exists in that profession a far more important career for the man who is competent to direct the traffic, classify goods, fix rates, watch the coming financial depression, know the signs of coming prosperity, have insight into as well as experience with the questions of labor and the relations of employers to employees, who can understand the duties as well as the privileges of corporations, and who has the masterly mind to direct and carry out great financial operations involved in the management of securities on a scale hitherto unprecedented." 
Purely technical or engineering training will not then suffice the man who aspires to leadership in railroading or in any like calling; he must be schooled in legal, political, and economic science as well.

There is no profession I know of that requires wider knowledge than does forestry. All the things which the best railroad man needs, the successful forester must have, with more besides. Since he deals scientifically with the soil and a product of it, he must be much of a geologist, botanist, zoologist, and chemist. The harvesting and manufacture of his crop calls for no mean engineering skill and knowledge. The managing of his property is likely to call for legal knowledge. And so on through many other essentials in his education, which only a real university can give him.

Another and most important reason why forestry should be a university course and not a separate school is that the forester is above all a man with practical problems to handle--a man who must come in contact with men. So he needs the democratizing influence of university life, the broadening of his point of view from association with men from everywhere and with different aims in life. Without this breadth of view how could foresters properly handle the many problems discussed before this Congress? It will take men far more catholic than those who academically settle affairs on the basis of knowledge acquired in their back yards to give a square deal to all the interests concerned in the creation of forest reserves and in the granting of timber and grazing permits on them; to devise schemes of fire prevention and extinction for all parts of our overburned country; to insure the growing of the right kind of trees in the right places; to improve our already expert logging and milling 
operations-no easy task, for the skill of our loggers and lumbermen is proverbial.

If I may as a Southerner use my section of the country as an example of the varied problems confronting the forester, I will say that we need him to point out our natural forest areas, and thus save us the time, effort, and substance which we otherwise might waste in clearing them only to find through bitter experience that they would grow nothing else than trees; to indicate the methods of logging which would insure the perpetuation of our standard trees, the yellow poplar, oaks, hickories, gums, cypress, and pines. One has already shown us a way to gather turpentine which has added millions to the revenues of the pine belt through improving the product, and which has greatly lengthened the period during which trees may be bled. We need him to solve our fire problem and devise means for prevention of and protection from this arch enemy of forest management. His scientifically established facts regarding tree growth, influences, and value present and future will strengthen our pleas to state legislatures for wisely conceived, far-sighted tax laws.

So we repeat this question: Why should not our universities offer courses which will fit men for all, instead of a few, professions? I know there are dangers to be apprehended, and that it will require the utmost care to avoid the Scylla and Charybdis of a narrow utilitarianism and the pursuit of art and science as ends in themselves; but of the many advantages, not the least will be the introduction of a vitalizing and democratizing element into the student community which will cause our universities to come forth from their cloistered seclusion into a closer touch with the activities of life. 
This is the great problem of the twentieth century. It overshadows all others. Signs are not wanting that we shall witness the full realization of all that President Hadley has so admirably expressed in the following words:

"Our brotherhood knows no bounds of occupation. The day when people thought of the learned professions as something set apart from all others, the exclusive property of a privileged few, is past. Opinions may differ as to the achievements of democracy; but none can fail to value that growing democracy of letters which makes of every calling a learned and noble profession, when it is pursued with the clearness of vision which is furnished by science or history and with the disinterested devotion to the public welfare which true learning inspires. We are proud to have with us not only the theologian, the jurist, or the physician; not merely the historical investigator or the scientific discoverer; but the men of every name, who, by arms or arts, in letters or in commerce, have contributed to bring all callings equally within the scope of university life."

We are about to see the proper university recognition given to the callings upon which so much of our national welfare depends-agriculture, the production and harvesting of field crops; silviculture, the production and harvesting of forest crops.

For the fulfilment of this prophecy, the recent utterances of our educational leaders and the munificent gifts of our men of wealth give us hope and encouragement. It is of the very spirit and life of our democracy, and it must come. Of all the great movements of the twentieth century, none will prove more characteristic of democracy and more vital and vivifying than the establishment of "an elementary school 
in every home, of a secondary school in every city, township or incorporated village, and of a university in every state"-a university which will be the inseparable adjunct as it is the apex of the whole educational system, where all branches of human learning are taught and all professions and callings-law and medicine, theology and teaching, commerce, trade, and industry, agriculture and silviculture-are made equal, a federation of them all being recognized as the only basis of educational solidarity. Then there will be coördination and coöperation instead of competition and rivalry. There will be gathered the representatives of every class and station, of every calling and profession, of every political and religious creed, constituting a body politic, a vertitable democracy, learning the lesson of citizenship as well as of scholarship; lighting at this central fire the Torch of Universal Truth and passing it from teacher to pupil, onward to the end of time. 


\title{
IMPORTANCE OF THE FORESTS TO AGRICULTURE
}

\author{
BY \\ HON. JOHN LAMB \\ Member of Congress from Virginia
}

$T^{H E}$ preservation of the forests of America is a subject of vast importance, and one that has been too long neglected.

Should the deliberations of this Congress result in calling the attention of our landowners, farmers and mechanics to this impending national danger, beyond the power of figures to compute, its members and delegates will richly deserve the gratitude of future generations.

Within the lives of many of us the question of the destruction of the forests did not arise. We have seen the log piles, and witnessed the destruction of millions of feet of the finest timber that ever grew, that the land might be cultivated in corn, cotton and tobacco. Some of us have seen this land turned out to grow up in scrub pines and oaks, while fresh forests were denuded of timber that would have enriched the next generation.

The unnecessary destruction of the forests in this way has brought untold loss to the Alantic States, from New England to the Gulf of Mexico. It has been estimated that in the State of New York alone between 1850 and 1860 , more than $1,500,000$ acres of timber land were cleared for purposes of lumber and agriculture. During that decade more than 50,000,000 acres in the whole country were brought under cultivation. 


\section{AMERICAN Forest CONGRESS}

The destruction of the forests during the Civil War has not and cannot be computed. This loss affected the agricultural interests in every State that was the scene of operations. The destruction of large forests, the gradual growth of hundreds of years, caused immense loss. Both armies contributed to this. Costly bridges, dwellings, and out-houses were consumed by fire. The relaying of railroads and rebuilding of bridges and dwellings demanded a new supply, and helped to drain the country of timber that was left. Native Virginians in some sections refused to remain where all the timber had been swept away. For the same reason emigrants declined to come to some of the finest parts of the State.

The menace to health is greatly augmented by the destruction of the forests, and the farmers of this country have suffered and are still suffering, to an alarming extent from this cause. We have no dry statistics on this point, but the experience of many, and the observation of all who travel, will confirm the statement.

The counties of Culpeper and Fauquier, in Virginia, were singularly free from malaria while their forests stood comparatively undisturbed. After the destruction of these, through war and other causes, fevers, before unknown, became prevalent.

The elderly physicians of Eastern Virginia might furnish an interesting chapter to history on this point; for it is one that deeply concerns the welfare of the farmers of the whole country, who are suffering in many ways from the wasteful destruction of the forests. It is to be hoped that our Department of Agriculture will investigate the health conditions that prevail after the removal of the forests from certain localities, and request the medical fraternity to furnish their valuable experiences along this line. 
It is well known that a house surrounded by forest trees is nearly always healthy. A gentleman who occupied such a home for ten or twelve years in one of the eastern counties of Virginia had no sickness of consequence in his family and did not pay a physician fifty dollars during that time. He afterwards purchased a large farm, surrounded by large tracts of cleared land with few trees, and lost in a few years several members of his family, and contributed to the doctors a goodly part of his profits.

The ceaseless reproduction of the pine forests of the South Atlantic States is all that has saved the farms and farmers of that section from destruction. For over two hundred years there has been a ceaseless war upon the forest. The early settlers cut it down and burned it up, and their children, with few exceptions, followed their example. Then came the general consumption for rails and wood; the demand for mechanical industry; the destruction for liquidation of farm debts; the sale of cordwood and sawed lumber to northern markets, till every tree of the original growth in most of the States have been removed. The second growth of old field pine is now receiving the same treatment, with smaller profit to the seller and poorer results to the consumer. Could the farmers of these States be persuaded to adopt the intensive system of farming, and have their poorer lands grow up in timber, they would improve their own condition, and hand down to their children valuable possessions. A gentleman of my acquaintance informed me that where he planted corn when a boy, he had cut from the land, a few years ago, cordwood, which he sold for eight dollars a cord in New York city.

Many thoughtful persons have claimed that the wood 
and timber interests of some sections of the South have militated against agriculture in various waysnot to mention the effect on the waterfall-and the injury resulting from overflows and freshets.

The disastrous results of the latter, caused by the removal of the forests along the banks of the rivers, cannot be learned from any statistics. The report made to our Committee of Agriculture shows a distressing condition, and one that appeals strongly for Federal and State legislation. Many valuable farms have been impaired in value, and some utterly destroyed, by the sand and debris washed down by the overflows. Cities and villages that were not affected years ago are now often flooded with water, eight to fifteen feet deep. All this shows the importance of forests to agriculture, and appeals to the American people to spare the trees, and will in time-not far off-compel the State legislatures, as well as the Federal Government, to take action in the premises.

We learn from the experiences of other nations the consequences of the continued destruction of the forests. Palestine, Egypt, Italy and France have seen some of their populous regions turned into a wilderness, and their fertile lands into deserts. The danger here is greater than many suppose. Immediate action, both for prevention and restoration, is needed.

"Bernard Pallissy," the famous "Potter of the Tuilleries," one of the most profound men ever produced in Europe, plead for the wood in France as follows:

Having expressed his indignation at the folly of men in destroying the woods, his interlocutor defends the policy of felling them by citing the examples of divers bishops, cardinals, priors, abbotts, monkeries and chapters, which by cutting their woods have made three profits; the sale of the timber, the rent of the 
ground, and the good portion of the grain grown by the peasants upon it. To this argument Pallissy replies: "I cannot enough detest this thing, and I call it not an error but a curse and calamity to all France; for when the forests shall be cut all arts shall cease, and they who practice them shall be driven out to eat grass with Nebuchadnezzar and the beasts of the field. I have divers times thought to set down in writing the arts that shall perish when there shall be no more wood, but when I had written down a great number, I did perceive that there could be no end of my writing, and having diligently considered, I found there was not any which could be followed without wood. $* * *$ And truly I could well allege to thee a thousand reasons, but 'tis so cheap a philosophy that the very chamber wenches, if they do but think, may see that without wood it is not possible to exercise any manner of human art or cunning."

G.P.Marsh, in his valuable work "Man and Nature," page 232, says: "There are parts of Asia Minor, of Northern Africa, of Greece, and even of Alpine Europe, where the operations of causes set in action by man has brought the face of earth to a desolation almost as complete as that of the moon; and though, within that brief space of time men call the 'historical period' they are known to have been covered with luxuriant woods, verdant pastures and fertile meadows, they are now too far deteriorated to be reclaimable by man; nor can they become again fitted for human use except through great geological changes, or other mysterious influences or agencies of which we have no present knowledge, or over which we have no prospective control.

"The destructive changes occasioned by the agency of man upon the flanks of the Alps, the Appennines, 
the Pyrennes, and other mountain ranges in central and southern Europe, and the progress of physical deterioration, have become so rapid that, in some localities, a single generation has witnessed the beginning and the end of the melancholy revolution.

"It is certain that a desolation like that which has overwhelmed many once beautiful and fertile regions of Europe awaits an important part of the territory of the United States, unless prompt measures are taken to check the action of destructive causes already in operation. $* * *$

"The only legal provisions from which anything can be hoped are such as shall make it a matter of private advantage to the landholder to spare the trees upon his ground, and promote the growth of young wood. Something may be done by exempting standing forests from taxation, and by imposing taxes on wood felled for fuel or timber; something by premiums or honorary distinctions for judicious management of the woods. It would be difficult to induce governments, general or local, to make the necessary appropriations for such purposes. But there can be no doubt that it would be sound economy in the end."

It is claimed that about two hundred square miles of fertile soil are washed into the rivers annually in the United States, while the loss in crops and other property destroyed by floods will run up into the millions.

The most of this loss can be traced to the destruction of the forests along the river banks.

Forest-covered areas retain a large percentage of the rainfall, while regions where there are no forests allow a much greater proportion of the rainfall to at once find its way into the streams. It is well known that many of our streams are subject to more disastrous 
floods and to lower water stages in dry seasons than was the case before the forests were cut off.

Whether forests increase the amount of precipitation or not-on this authorities are not agreed-it is very certain from the observation and experience of those who live in the country that local showers are rsore frequent in the neighborhood of dense forests. We may well contend that the forest helps to water the farm; that it protects from disastrous wind storms, both in winter and summer; prevents the spread of disease, besides furnishing an inexhaustible and selfrenewing supply of a material indispensable to the successful exercise of every art of peace, as well as much of the destructive energy of war.

So important is this subject that the farmers of this country should hail with delight the work of this Congress, and join hands with you in the earnest effort you are now and will hereafter make to save America from the disaster that has overtaken many countries in Europe.

Experience has shown that no legislation can secure the permanence of the forests in private hands. The farmers must be educated along this line. The earnest efforts of the Department of Agriculture must be encouraged, and the means necessary for the sending out of literature must be furnished by the Congress. Such Bulletins as Nos. 67 and I73, by B. E. Fernow, of the Division of Forestry, will accomplish a great deal. The farmers' institutes in the states must take up the subject and help to create a public sentiment that will change present conditions and lead to tree planting on many other than Arbor days.

Every word written, printed or spoken on this subject will bring a blessing and the author will deserve public thanks. As a subject of political economy no 
more important one can be brought to the attention of the citizens of this republic.

As a people we have solved some vexing problems. Many others confront us to-day, and will tax our patience, courage, and endurance. Profiting by the experience of other countries, impelled by the imminent dangers of the present time, and encouraged by the prospect of laying up for future generations a supply of material necessary to their comfort and safety, we should devote our energies to the work of restoring the American forests. We know that growth is slow, and restoration tedious. We also know that the perseverance and energy of the American is equal to any task he assumes.

'We have $5,674,875$ farmers in this country. Could one-third of these be induced to plant half an acre each in forest trees a year, we would have nearly a million acres a year added to the forests. In a decade at this rate we would have gone very far in solving a problem of great moment, and feel that we had done much towards offsetting the destruction and preventing the coming desolation.

The preservation and restoration of the American forests will greatly add to the comfort and beauty of our homes, and tend to keep the youths of the land in the rural districts, free from the temptations and vices of city life. The migration from country to city is an alarming feature of our social life. There are already indications of the returning tide. The preservation of the forests and the beautifying of country homes will strengthen the patriotic sentiment in the country and intensify reverence for home.

A lack of reverence is a growing evil in our land. We observe it everywhere, North, South, East, and West. Students, philosophers, and divines inveigh 
against it, offering various remedies for the evil.

We suggest the preservation of home and home ties, the cultivation of reverence for Mother Earth, and the preservation of the noble forests.

It is the earth alone of all the elements around us that is never found an enemy to man. The great body of waters oppress him with rain and devour him with inundations. The air rushes on in storms and prepares the tempest or lights up the volcano; but the earth, gentle and indulgent, ever subservient to the wants of man, spreads his walk with flowers and his table with plenty; returns with interest every good intrusted to her care; and though she produces the poison, still supplies the antidote; though teased more to supply his luxuries than his necessities, yet even to the last she continues her kind indulgence, and when life is over piously hides his remains in her bosom. 


\section{DEPENDENCE OF BUSINESS INTERESTS UPON THE FORESTS}

BY

\section{HOWARD ELLIOTT}

President, Northern Pacific Railway

MN may, and do, differ widely in their views as 1 to the extent to which Federal control and supervision should be applied to various forms of business in the United States, but there can be less difference of opinion over the idea that the preservation and reproduction of the forests must, at present, be undertaken by the Federal or State Governments, or both, if the work is to be done at all. Possibly as the subject becomes better understood private capital can undertake this work in some sections where the conditions are favorable, but, at the present time, it is probably true that forest reproduction by individuals will not stand the test of yielding an adequate return on the investment. Recognition of these conditions, and the importance of forest preservation to the reclamation of the arid lands have resulted in the adoption of a public Forest Reserve policy which should receive support, suggestion, and approval. Business enterprises that are dependent upon the forests should recognize this condition and plan accordingly.

I feel that I owe some apology for venturing to say anything to this meeting, composed of men who have spent more time than I have, and who know more than I do on the general subject of forestry, and its relations to the welfare of the country, now and in the 
future. A very great personal and business interest in the subject is my excuse for being here.

The Northern Pacific Railway Company, of which I have the honor to be the president, traverses states in which there are forest reserves as follows:

\begin{tabular}{|c|c|c|c|}
\hline $\begin{array}{l}\text { State. } \\
\text { Minnesota ............. }\end{array}$ & $\begin{array}{c}\text { Existing } \\
\text { Acres. } \\
\text {......... }\end{array}$ & $\begin{array}{c}\text { Proposed } \\
\text { Acres. } \\
708,840\end{array}$ & $\begin{array}{l}\text { Total } \\
\text { Acres. } \\
798,840\end{array}$ \\
\hline Montana ............. & $7,882,400$ & $4,077,700$ & I $1,960,100$ \\
\hline Idaho $\ldots . \ldots \ldots \ldots \ldots$. & $3,955,220$ & $3,501,520$ & $7,456,740$ \\
\hline Washington .......... & $7,012,960$ & $2,603,480$ & $9,616,440$ \\
\hline Total & & 540 & 29,7 \\
\hline
\end{tabular}

a total in which the Northern Pacific Railway Company is interested, of nearly $30,000,000$ acres.

Included in this acreage are lands granted to the Northern Pacific Railway Company, amounting to:

Montana ......................, 1,507, $\mathbf{1 3 0 . 5 3}$ Idaho ......................... $228,208.36$

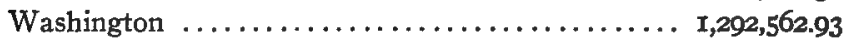

Total $\ldots \ldots \ldots \ldots \ldots \ldots \ldots \ldots \ldots \ldots, 3,027,901.82$

These lands were given by the Government in I864, to induce the building of the road at a time when even the wisest owners of capital hesitated about undertaking an enterprise so large, and so doubtful as to the outcome; and the discouragement and losses to those investing in this railroad, until within the last few years, are a matter of common knowledge.

During the last five years, of the freight handled by the Northern Pacific Railway, forest product shipments were: 
Tons.

For the year ending June $30,1900 . \ldots \ldots \ldots \ldots \ldots .2,207,526$

For the year ending June $30,1901 \ldots \ldots \ldots \ldots \ldots \ldots 2,741,708$

For the year ending June $30,1902 \ldots \ldots \ldots \ldots \ldots \ldots . \ldots .69,694,694$

For the year ending June $30,1903 \ldots \ldots \ldots \ldots \ldots \ldots, 5,090,387$

For the year ending June $30,1904 \ldots \ldots \ldots \ldots \ldots \ldots .5,285,077$

The prosperity and future growth of North Dakota, of Montana, of Idaho, and of Washington, are dependent very largely upon the successful irrigation of lands adjacent to the streams and rivers which find their source of supply in the mountains covered by the existing or proposed forest reserves.

And the Northern Pacific, in common with all other railroads, is vitally interested in the subject of ties and timber with which to maintain existing railroads, and to build new ones.

So the interest I represent is, and will be, affected very directly by the work of the Government in connection with the forests, and to-day an earnest effort is being made to arrive at some fair basis of adjustment between the Government and the Northern Pacific Railway Company so as to obtain the best results in the Forest Reserves controlled by the Government, and preserve to the railroad its acreage for its use in obtaining ties and timber in the future.

Hence, when your gifted Forester, Mr. Gifford Pinchot, and your worthy and energetic President, the Honorable Secretary of Agriculture, asked me to participate in this meeting, I hesitated, but finally accepted with some reluctance, feeling that I could bring little that was new to the discussion. I accepted because it seemed ungracious to decline the cordial invitation, and because I wished to express, so far as possible, by my presence here, the interest that the Northern Pacific Railway Company takes in the whole 
subject, and to encourage other railroads to do likewise; to express, further, the willingness and intention of our company to coöperate on reasonable lines with the Federal Government for better forest methods and wood treatment, and to emphasize the importance to many large interests and to railroad business particularly, of being less wasteful and prodigal with the wooden materials used in commercial enterprises in the United States.

The first great business directly dependent upon the forest is that of the lumberman; there is probably invested in logging camps, saw mills, planing mills and other enterprises incident to producing forest products in the rough, over $\$ 1,000,000,000$. Upon this great business, employing many men, and paying out millions annually in wages, depend in turn very many manufacturing enterprises scattered from one end of the United States to the other; depend the wood pulp and paper business of the country; depend in part the successful prosecution of many mining enterprises.

The transportation business is dependent upon the success of these commercial enterprises, and they in turn are dependent upon a safe, efficient, prompt, and economical system of transportation.

Many of the manufacturing interests will be slackened, depressed, and perhaps stopped entirely, unless steps are taken to use to the best advantage the forests we now have, and to arrange to reproduce them for use in the future.

The railroads represent in round figures an investment of about $\$ 13,000,000,000$. They collect and disbursement annually about $\$ 2,000,000,000$, of which $\$ 800,000,000$ goes directly to labor. They carry in a year 21,000,000,000 passengers one mile; they transport in a year $180,000,000,000$ tons of freight one mile 
at an average rate of three-fourths of a cent per ton per mile, far lower than the rates in any other country in the world; and they do this with wages far higher than in any other country in the world, and with a general service far better than that given by any other nation.

An absolutely essential part of a modern railroad is a safe, strong, and good track, and these figures about railroads are given simply to show the magnitude of that business in investment, in wages, in work done, and in the price paid therefor. Anything that tends to make the maintenance and operation of this great commercial tool more expensive must be offset either by a decrease in wages, by an increase in rates, by a decrease in efficiency, by a decrease in returns to owners, or by all combined.

To have good track the railroads must have some form of support under the rails, and the present practice is a wooden tie. In this item alone, based upon the actual requirements for a period of years by one large system, it is estimated that the total annual consumption of ties, for renewals only, in all of the railroads of the United States, is at least $100,000,000$, to which add $20,000,000$ for additional tracks and yards, and for the construction of new railroads, and the total is the equivalent in board measure of more than $4,000,-$ $\infty 00,000$ feet.

The significance of these figures is more apparent when it is remembered that about 200 ties is the average yield per acre of forest, varying very greatly in different localities; so that to supply this single item necessitates the denudation annually of over one-half million acres of forest. But the cross tie supply is only one of the forest products required by the railroads. There are bridge timbers, fence posts, tele- 
graph poles, building timber of all kinds, car materialall of which together, it is estimated, will equal in board measure the cross tie item, so that it is possible that the railroads of the United States, for all purposes, require, under present practices, the entire product of almost one million acres of the forest annually.

So the railroad business, as well as the manufacturing business, in a number of directions, is interested in, and very dependent upon, the preservation of the forests of this country, and in a wise handling of the subject by the Government, both National and State; in the continuance of the supply of timber for use now and in the future; in the revenue derived from the transportation of forest products; in conserving the water supply of the country so that the maximum amount of arid land may be irrigated and thus support a producíng and consuming population.

Until the time came when the increase in distance from the point of supply of timber, and the increase in the value of the stumpage, resulted in an increase in the cost of all items of forest products, not much attention was paid by business interests, excepting by a far-seeing few, to the necessity for a conservative policy about the forest supply. Happily, before too late, there has been an awakening, the credit for which is due to the persistent efforts of those present.

On the part of the railroads, this awakening has taken the practical form of preservation of cross ties and other timbers so as to lengthen the life of the wood; to a greater use of metal, stone and cement; to the wiser cutting, handling and seasoning of ties and timber, and to a utilization of different kinds of wood for ties, and what is true with the railroad is also true with other important business interests dependent upon wood for their successful operation. 
This is something in which, as you will all know, this country is somewhat behind Europe, but I am glad to say nearly all the railroads in the last few years are thinking, and thinking very hard, on the subject, because the problem of how to support their rails is. more perplexing each year.

If the American railroads are to continue to be the efficient commercial tool that they now are; to continue the very low average rates, and the high scale of wages now in effect, the question of the increased cost of ties and timber is of greater and greater importance to those who pay transportation charges; to wage-earners, and to railroad owners.

The fact that so many large interests are so dependent upon the wise handling of the forests remaining in the country, will insure a greater coopperation in the future than there has been in the past between those who cut down and use the forests for money-making purposes, and those who are studying the subject in order to safeguard the interests of those who come after us.

This coöperation is very necessary, and the work of the National Government, the various State Governments, the state agricultural colleges, and the forest schools should, so far as possible, be along the same lines.

With such oöperation I have faith that the ingenuity, perseverance and ability of the American man will solve this important question; and that, in spite of a somewhat lavish use of our forest resources in the past, we shall be able, by a greater care in the future, and by a more extended use of materials, other than wood, preserve for ourselves and for those that come after us, the forests of the country for business, health, and pleasure. 



\section{PART II.}

IMPORTANCE OF THE PUBLIC FOREST LANDS TO IRRIGATION 



\title{
THE CLOSE RELATION BETWEEN FOR- ESTRY AND IRRIGATION
}

\author{
BY \\ GUY ELLIOT MITCHELL \\ Secretary, the National Irrigation Association
}

THE connection between a comprehensive system though vital one, directly affecting as it does but onehalf of the territory of the United States-the arid region. Forestry itself, as affecting water supply, is a broad national question, as well as a local one in each state and drainage basin. The forest movement, therefore, has a country-wide interest, and whereas California is alarmed over the destruction of its mountain forests and the drying up of its streams which form the life-blood of its communities, Pennsylvania and New England are only to a less extent exercised over the threatened danger to their water sources, necessary for city and town supplies and for power development.

In the Western half of the United States the destruction of forests has an intimate, immediate bearing upon the capacity of the States to sustain population, for population results from irrigation; irrigation depends upon water supply and the water supply is the melting snows caught and held by the forests clothing the great mountain chains of the Sierras and the Rockies-nature's great storage reservoirs.

Three things are necessary to insure a maxinum water supply for irrigation:

First, prevent wholesale destruction of timbered watersheds. 
Second, substitute therefor a, rational system of timber cutting; and,

Third, reforest and afforest lands where the value of the increased water supply will warrant this most advanced and expensive feature of the American forest plan.

The first of these should receive immediate consideration; the present tremendous waste should be checked and the second part of the plan promptly adopted before it is too late, and the third and most expensive part becomes the only remedy.

So far as the Government timber lands are concerned, aggregating many millions of acres outside of the national forest reserves, for every thousand dollars now expended in carrying out the first two provisions of the plan-where all-that is required is to properly direct timber cutting to husband the resources of nature, new growth-it is probably a conservative estimate to make that a million dollars, and much time will be required to attain the same results through forest planting.

This latter creative plan while less pressing and vital than the need of conserving what we already have, holds out wonderful eventual possibilities. The statement of Mr. Gifford Pinchot, Forester, United States Department of Agriculture, at the Twelfth National Irrigation Congress, at E1 Paso, Texas, November, 1904, that experiments and the observations of years have proven that enormous areas of the West can, by systematic planting, be made into forests with the effect of restoring streams which have disappeared, possibly thousands of years ago, and of creating entirely new streams, holds out startling and almost unrealizable probabilities for future agricultural development to the forest and water student. 
What is needed to-day, immediately, is vastly more -strength to the arm of American forestry for the vigorous prosecution of its well matured plans to save what we now possess. The two greatest problems before this country to-day, well worthy the expenditure by the nation of millions and hundreds of millions of dollars instead of thousands and hundreds of thou1sands, are forestry and irrigation. They will return such expenditure, principal and interest, many times over, and the carrying out of such a policy will demonstrate its wisdom within the present generation. It is a question demanding our immediate consideration, and is not, as many patriotic citizens seem to believe, a remote problem which must be solved in the distant future. I make no careless, ill-considered statement when I assert that these two correlated subjects form the most important question before the United States to-day and through whose wise solution the country has more to gain than from any other resource, within her borders or over seas. For can anything be of greater import than the creation of an empire within our midst which will support a population as great as that of the entire country to-day?

The work of the Bureau of Forestry of the Department of Agriculture has come, within the past two years, to be recognized as a practical, hard-headed business proposition. When the present Forester, Mr. Gifford Pinchot, took up this work he gave lumbermen credit for shrewdness and ability; he did not claim to know more than they about lumbering; but he did contend that lumbering could be carried on profitably without forest destruction. Later, when criticised for his enthusiasm in the setting apart of forest reserves and his supposed substitution of practical lumbering for the æsthetic considerations, he made the notable response: 
"I am not a preserver of trees. I am a cutter-down of trees. It is the essence of forestry to have trees harvested when they are ripe, and followed by successive crops. The human race is not destroyed because the individual dies. Every individual must die, but the race lives on. So every tree must die, but the forest will be extended and multiplied. Yet it by no means follows that the face of the land shall be denuded, so that the character of the watersheds shall be altered, with the resulting injury to streams and to agricultural lands depending upon them."

The United States is quite fortunate in the possession of Gifford Pinchot as Government Forester; the President is fortunate in having a man to carry out this advanced forest policy, a man who is striving solely to conserve one of the greatest of America's natural resources, thus erecting to himself and his period a monument which will endure for all ages.

President Roosevelt has uttered some notable truths as to the relation of forest preservation to agriculture and home building. Speaking at Leland Stanford University last year, he said: "In many parts of California the whole future welfare of the State depends upon the way in which you are able to use your water supply; and the preservation of the forests and the preservation of the use of the water are inseparably connected. Whatever tends to destroy the water supply of the Sacramento, the San Gabriel, and the other valleys strikes vitally at the welfare of California. The forest cover upon the drainage basins of streams tused for irrigation purposes is of prime importance to the interests of the entire State." And, again: "Now keep in mind that the whole object of forest protection is, as I have said again and again, the making and maintaining of prosperous homes. Every phase 
of the land policy of the United States is, as it by right ought to be, directed to the upbuilding of the homemaker. The one sure test of all public land legislation should be: Does it help to make and keep prosperous homes? If it does, the legislation is good. If it does not, the legislation is bad.

"Certain of our land laws, however beneficent their purposes, have been twisted into an improper use, so that there have grown up abuses under them by which they tend to create a class of men who, under one color and another, obtain large tracts of soil for speculative purposes, or to rent out to others."

Two bills are pending in Congress to-day, the passage of which will prove a distinct gain to American forestry. They are little understood, probably, by the American people as a whole, yet it is doubtful if there are any pending before Congress fraught with greater import to the nation. One has passed the House and the other one has passed the Senate. The former bill consolidates the entire government forest work, now badly divided and cut tip among different bureaus and divisions, into one bureau under the Department of Agriculture.* It has the unanimous support and approval of various officials, the heads of departments and the Executive. It should promptly become a law and the country should then stand by its Bureau of Forestry with such support as is necessary to carry out its forestry plans in the broadest and most comprehensive manner, for by doing so it will conserve greatly its own wealth.

The other measure has likewise the unqualified support of the President, all forest officials and heads of departments. It passed the Senate without a dissent-

* This bill has since passed Congress and was signed by President Roosevelt, February I, Ig05. 
ing vote. It provides for the substitution of the timber and stone law with a plan to allow the general government to retain title to all its timber lands, but to sell the timber thereon under such regulations as will insure the perpetual reforestation of these lands, their timber cropping, and the preservation of their water supplies.

Under the present law timber land of great value is disposed of by the Government at $\$ 2.50$ an acre, is carelessly and wastefully lumbered so that entire watersheds are denuded of their forest cover, destructive fires are allowed to sweep over them leaving them bare and unable to retain the moisture upon which irrigated communities depend. This law was passed to enable settlers to purchase small tracts of timber land, presumably adjacent to their homsteads. Its provisions have been evaded, as the President intimates, to such an extent that enormous tracts of land have passed into speculative ownership without resulting good to the communities; in fact, with the utmost danger to their prosperity and well being. This measure should likewise receive the prompt consideration of that branch of Congress before which it is pending.

There is yet another law which stands as a great menace to forest preservation. It is the forest reserve lieu land law, known as lieu land or scrip law. It allows the owner of land within the forest reserves to exchange that land for other unreserved public land of the reserves. Under it vast areas of almost worthless land, in many cases previously denuded of its timber by its owners, have been exchanged for the finest timber lands in the Northwest. This law should be repealed, and where private individuals or corporations own land within the forest reserves which they do not desire, it should be appraised by the Government and 


\section{AMERICAN Forest CONGRESS}

the cash value paid to the owner of one or two dollars an acre, or whatever it may be worth, rather than that he should be allowed to exchange it for equal areas of our finest timber lands worth $\$ 20, \$ 50$, and possibly $\$ \mathrm{IoO}$ an acre. The particularly evil feature of this law is that lieu land right is a floating, purchasable commodity, and has resulted in the acquirement of immense tracts under single ownership.*

With these three measures acted upon by Congress the nation will emerge from the present area of lumber waste and timber land speculation into one of forest conservation, husbandry, and thrift which will result in both timber supplies and water resources for the coming generations, where the present outlook indicates timber famine and vast loss to irrigation.

*The lieu land law was repealed by Congress in March of this year. 


\title{
FORESTS AND RESERVOIRS
}

\author{
BY \\ F. H. NEWELL
}

Chief Engineer, United States Reclamation Service

$A^{L L}$ are aware that the Government, through the operation of the Reclamation Act of June 17, I902, is building large irrigation works throughout the West. The fund for that purpose now amounts to about $\$ 25,000,000$. These works, national in character, are being constructed as rapidly as possible. The protection of these works, their future use, their stability through all time, is largely dependent upon the proper treatment of the forests upon the mountains above the reservoirs. In fact there is hardly a project now under consideration whose future success is not closely joined with the questions of the best use and preservation of the forests and to a less degree of the grazing land immediately adjacent. These works are being built to last for all time, and if they are to be preserved in their best condition, it must be after we have solved this question of the best protection and use of the forest.

A number of the delegates present have come from the far West. Many others are deeply interested in Western development, not only from general considerations, but because the creation of a home in the West means the creation of a home in the manufacturing districts of the East, and possibly the creation of a home for a man who is employed by the transporting interests. The transportation men, so well represented at this Congress, have an immediate and vital concern in this whole subject of conservation of 
water and, growing out of that, the conservation of the forests.

It is desirable to review briefly something of what is going on in the Western States and Territories. Take Arizona, for instance: Here the Reclamation Service is building a storage dam at Roosevelt, costing probably $\$ 3,000,000$. When built it will enable the creation of homes for many thousands of people, and render productive a large area now desert. In California is the Yuma project, which it is expected will be begun soon; and also another project in the northern part of the State, around the Klamath lakes. For the protection of an Arizona reservoir a forest reserve must be had above the reservoir in order to prevent, as far as possible, the washing of soil which follows upon the destruction of tree growth. In Colorado is the Gunnison tunnel, the contract for which is being let now-a tunnel 30,000 feet in length, to take water from the Gunnison River into the Uncompahgre Valley, a broad, fertile, but arid plain. The head waters of that river must be protected in part by the forests as well as by reservoirs.

In Idaho, the same is true; there on the Snake River a dam is being built across the stream. Its utility for all time depends largely upon the good treatment accorded to the head waters of that stream. This matter of the development of the West is not a State question, but is interstate. We must build reservoirs in Wyoming; we must conserve forests in Wyoming to benefit the arid plains of Idaho. For Western Kansas, Mr. Reeder has already spoken briefly of the great interest in irrigation, and although having no forests, yet the rivers that come into Kansas, as the Arkansas, depend partly for their continuity of flow on proper treatment of the woodlands on the mountains in the central part of Colorado. 
In Montana are similar conditions. The Yellowstone River, rising in Wyoming, derives a large water supply from wooded areas which must be protected in order that the flow of that stream may be properly safeguarded. In Nebraska, the conditions are similar to those in Western Kansas. The North and South Platte Rivers coming into that State, are dependent for their waters, in part at least, upon the flow from the high mountains of Central Colorado and Southern Wyoming. In Nevada is under construction one of the largest irrigation works in the world, taking water from Truckee River over into the Carson. The integrity of that great system, which will cost at least $\$ 3,000,000$ and possibly $\$ 5,000,000$ when it is completed, will depend largely on the conservation of the forest growth in the State of California; there again is the same question of protection of forests in one State to secure the prosperity of the homes in another. In New Mexico is being built on Hondo River, a tributary of Pecos River, a reservoir which receives its waters from forest reserves in central New Mexico. There is in contemplation a great work on the Rio Grande, interstate and international in character; that river in turn must be reservoired and every drop of water held. Here again comes the question, how are the head waters of that river in Colorado to be best protected for the waters which are to be used in Colorado, New Mexico, Texas, and Old Mexico?

North Dakota is far out on the plains and there are few forests in the State. The great river of the State is the Missouri, rising in Montana. This stream depends largely for its flow on the waters from forests at its head. South Dakota has a mountain region of its own and a forest reserve in the, Black Hills. ' 'Coming from the Black Hills are streams, not very 
large but of very great importance in the development of that State. On the Belle Fourche River there is being planned a large irrigation system irrigating vast tracts of land north of the Black Hills, lands which will form homes for thousands of families. Again we have the same old story that we must go back to the forest reserves to see that the head waters are protected.

In Oregon we know of the wonderful extent of the forest reserves and of the value of the timber, but even in that State we are asking for better and larger attention to the forest reserves, especially in the Blue Mountain region and particularly on the head waters of the Malheur, Umatilla, and other streams where development to a high degree will be possible. Oklahoma, out on the plains, has, it is true, but little forested area, but even there, are questions of water storage and of the best protection of a little reserve in the Wichita Mountains. In Utah the same is true. There we are studying Utah Lake and the best use of waters which flow through it and out into the Jordan; also the best use of Bear Lake. Here we come back again to the question, What is Mr. Pinchot going to do with the forest reserves? Mr. Pinchot and the engineers of the Reclamation Service are working hand in hand on all the large projects which look to home-making and upbuilding of the country.

In Washington the same condition exists. The Palouse project, in that State, is for storage of water at the head of the Palouse River and for taking it out to reclaim a sandy desert above Pasco. This will be made one of the most productive sections in the United States. Last, but not least, we come to Wyoming, the central, the pivotal State of the arid region; a State of great elevation. There we must have forest reserves to 
protect the head waters of the Missouri and Yellowstone, the head waters of the Platte and all of the innumerable streams which flow, not only to the East, but also into the Snake and into the Green Rivers to the South.

In each of these States is a great irrigation project under construction or under consideration. In Wyoming is a large reservoir on the North Platte Riverthe Pathfinder. The contract for the outlet tunnel will be let in a few days. And in the northern part of Wyoming is a project on the Shoshone River with the object of reclaiming vast tracts of arid land.

I have cited these cases to illustrate the fact that forest protection has an important practical and definite value, not only to the people of the West, but to the people of the whole country in the upbuilding and making of homes and the creation of a large population which will support itself from the soil. And which will be drawing upon the East for its manufactures and drawing upon all the transportation interests to carry these manufactures backward and forward.

Those of you who are interested in the details of this great work of reclamation are cordially invited to go into the details with the engineers of the Reclamation Service who represent the different States and who are now holding a conference to consider some of the larger problems of construction and of management. These works are not built as are those constructed under such appropriations as that provided for in the River and Harbor Bill. They must be built, on the contrary, with the idea of repaying to the government the cost of construction. This involves a financial problem-that of getting back into the reclamation fund the amount which each project has cost. If it has cost $\$ 3,000,000$ dollars and will reclaim I00,000 
acres of land, then each acre of land must be assessed thirty dollars, and that thirty dollars must be paid back in ten annual installments of three dollars each. Meanwhile the fund is increasing, but every dollar of it must be guarded and the engineers in charge of the work must be business men and financial men as well, and see that the expenditures they make are such that the money will get back without undue hardship to the people who will obtain that land and cultivate it.

These great works belong to the National Government, but when the distribution system is paid for in the ten annual installments, it will be turned over to the people who own the land and cultivate it and will be operated by them very much as a school district is operated, or any other public corporation or municipality. During the time of construction and operation of these works up to the period when they are paid for, the engineers who have built them will see that they are operated properly and will gradually pass the control over to the communities until ultimately the community will assume full control. By that time the future owners will be educated to a true appreciation of the great works and to a realization of what it means to them to conserve the forests of the head waters.

The organization which is carrying on that work known as the Reclamation Service, has been created under the Geological Survey in order to take advantage of the good precedents and business-like ability of that organization. All of us appreciate the enormous benefit it is to have, the protection of the older organization which has been in existence a quarter of a century and which has been conducted without favoritism and without reference to politics.

Building up on that foundation and having the protection of good precedents and good methods, we are 
endeavoring to develop a strong organization. We ask you who are interested in forestry and in all its practical developments and ramifications, to stand with us and give us your assistance to keep and protect this young organization along the lines of good, hard business sense. Not only for the sake of the development of the country, not only for the sake of the reclamation of the West, but for the good example and encouragement it affords to other organizations of the Government, such as the Forest Service, to pursue the same lines in carrying on the work on a thoroughly sound financial basis, of getting back what the service costs and not making it a burden upon the country.

It is of the highest importance to demonstrate to the public and to Congress, the fact that public business can be transacted on business lines. There are many good men who scoff at the idea that the public service can be conducted on a sound basis of that kind, but I believe it is possible for the Forestry and for the Reclamation Services to be carried on as a business proposition and pay for themselves and not call upon the Federal Treasury for a cent. And to upbuild and utilize all the resources, if you business men, who are citizens who are interested in good government, will stand with us and insist that these sound principles be carried out. 


\section{RELATION OF FOREST COVER TO STREAM FLOW}

\section{BY}

\section{J. B. LIPPINCOTT}

Supervising Engineer, United States Reclamation Service

$T^{H E}$ relation of rainfall to run-off is very uncertain, depending upon the nature of the storms, whether gentle showers or violent rains; the steepness of the drainage basin and its covering, and whether the precipitation is snow or rain. It has been found that in the districts where the forest cover is small the output of the basin occurs in violent floods of short duration. Because these floods are violent, and of large volume, and owing to the fact that the soil of the drainage basins is not hold together by a network of roots, extensive erosions occur in these barren basins and the stream carries much silt in suspension. Where the basin is covered by forest, the mat of twigs and leaves which covers the ground is an absorbent sponge, retaining in itself large quantities of water and preventing evaporation from the underlying soil. This permits of a holding back of the floods and the gradual draining off of the water, thus largely accomplishing the purpose of regulating reservoirs.

A striking example of the output of a barren, treeless, drainage basin is shown in the case of Queen Creek, Arizona, for the year I896. This stream discharges only in violent freshets, recurring usually as great flood-waves, subsiding almost as rapidly as they arise. By making from two to three current-meter measurements of each of these freshets, and keeping 
an hourly record of the gauge-height, the discharge was approximated. The floods are usually not to exceed twelve hours in duration. During a larger portion of the year the channel is nearly dry. Queen Creek rises in the mountains to the southeast of Phœnix, and flows in a generally southwesterly direction, losing itself in the desert north of the Gila River Reservation. The area of the drainage basin is $\mathbf{I} 43$ square miles, of which 6I per cent. is above an elevation of 3,000 feet, and 39 per cent below that elevation. The annual discharge is approximately I0,000 acre feet. The basin is almost entirely bare, there being a few pinion trees and very little brush or grass. The following table of discharge for the year 1896 for Queen Creek is taken from the Eighteenth Annual Report of the Geological Survey, Part IV, Hydrography. It represents a typical year's output:

Estrmated Monthly Discharge of Quien Crét at Whitlow's, Arizona. Drainage Areia, i43 Square Miliss.

\begin{tabular}{|c|c|c|c|}
\hline & & Se & \\
\hline Month, I896. & Max. & Min. & Mean. \\
\hline antuary......... & 2 & 2.0 & 2.0 \\
\hline February.............. & 2 & 2.0 & 2.0 \\
\hline Iarch................ & 2 & 2.0 & 2.0 \\
\hline April............... & 2 & 1.0 & I.5 \\
\hline .... & I & I.0 & I.O \\
\hline une... & I & 1.0 & I.O \\
\hline uly $\ldots \ldots \ldots \ldots \ldots \ldots$ & 9,000 & 0.0 & 121.6 \\
\hline Atugust $\ldots \ldots \ldots \ldots \ldots$ & 1,433 & 0.6 & I3.I \\
\hline September.. & 3,428 & 0.5 & I7.I \\
\hline October................ & $\mathrm{I}, \mathrm{I} 88$ & 0.5 & i3.3 \\
\hline November.............. & 80 & 0.6 & I.3 \\
\hline December.............. & 207 & 0.6 & 2.0 \\
\hline & 9,000 & . 0 & I5. \\
\hline
\end{tabular}


In contrast with the Gila River and Queen Creek in Arizona, is the discharge of Cedar Creek Washington, for the year 1897. The point of measurement of this stream is at Clifford's Bridge, in Section I9, Township 22 North, Range 7 East, Willamette Meridian. The drainage area is estimated to be I43 square miles, and it, therefore, is the same as the area of the basin of Queen Creek. The basin of Cedar Creek lies on the western slope of the Cascade Mountains. It is heavily timbered and, in addition, the ground is covered with a very heavy growth of ferns and moss. The precipitation for the year 1897 was about 93 inches in the lower portion of the basin, and is estimated to have been as great as 150 inches on the mountain summits. The rainfall of the Queen Creek basin is estimated to be about 15 inches. The maximum flood discharge in 1896 on Queen Creek was 9,000 cubic feet per second, and the maximum flood discharge on Cedar Creek in 1897 was 3,60I cubic feet per second. The mean discharge for Queen Creek was I 5 cubic feet per second, and for Cedar Creek I,089 cubic feet per second. While Queen Creek is frequently dry, the minimum discharge of Cedar Creek during the period in question was never less than 27 per cent of the mean for the year. These two streams represent extreme types. The radical difference in their character is believed to be largely due to the difference in forest cover. The discharge of Cedar Creek for the year I897 is believed to be fairly representative. The following table of discharge is taken from the Nineteenth Annual Report of the Geological Survey, Part IV, Hydrography.

It will be noted that the vertical scale showing the discharge is twice as large on the Cedar Creek diagram as on that of Queen Creek. If they were on the same scale the contrast would be greater: 
Estimated Monthly Discharget of Ceddar River Near Seatthle, Washington. Drainage Area, I43 Square Miles.

\begin{tabular}{|c|c|c|c|}
\hline & \multicolumn{3}{|c|}{ Discharge in Second feet. } \\
\hline Month, I897. & $\operatorname{Max}$. & Min. & Mean. \\
\hline January............ & $2,8 \mathrm{I} 2$ & $8 \mathrm{I}_{5}$ & $I, 430$ \\
\hline February............ & $2,4 I 5$ & 823 & $I, 303$ \\
\hline March............. & 1,366 & 723 & $90 \mathrm{I}$ \\
\hline April............... & 2,752 & 790 & $I, 599$ \\
\hline May................ & 2,143 & 939 & $I, 562$ \\
\hline June.............. & $\mathrm{I}, 4 \mathrm{IO}$ & 780 & 1,060 \\
\hline July............... & 2,284 & 572 & I,I35 \\
\hline August............ & $56 \mathrm{I}$ & 342 & 427 \\
\hline September.......... & 418 & $3 \mathrm{II}$ & 350 \\
\hline October............ & 433 & 294 & 339 \\
\hline November.......... & $3, I 55$ & 323 & $I, 3 I 8$ \\
\hline December.......... & $3,60 I$ & 674 & I,639 \\
\hline Total............ & 3,601 & 294 & 1,089 \\
\hline
\end{tabular}

The amount of solid matter carried by a stream is a very serious problem in connection with the construction of storage reservoirs thereon. The most astonishing stories are told of volumes of sediment carried by the rivers of southern Arizona from their barren drainage basins. It is said that when these floods first appear, discharged off of ranges that have been travelled by the large herds of cattle in quest of grass, the soil which has been exposed to the direct action of the sun, being exceedingly light and dry, is washed off in quantities that are enormous. In order to determine the amount of silt in the Gila River at The Buttes, which stream has a similar basin and regimen to that of Queen Creek, the Geological Survey has made observations by taking samples of the water daily, and permitting the mud to settle in graduated tubes. The amount of mud is then determined by 
reading its height upon the graduations. The mud which is deposited has then been treated in the case of numerous samples to a temperature of 212 degrees Fah., and the final amount of solid matter determined by weight. Observations were continued from July 29, I895, to December 3I, of the same year. Beginning on January I, I899, and continuing until July $3 \mathrm{r}, 1899$, similar observations were made at the same station, the amount of mud and solid matter being determined as previously. During the first period the volume of water discharged at The Buttes was 360,523 acre feet, and it was found that this contained 37,984 acre feet of silt by volume wet. This reduced to 7,704 acre feet of solids. The average amount of light sediment during this first period was $101 / 2$ per cent by volume wet, and the amount of solids a little over 2 per cent. The total amount of water discharged during the second period in 1899 was 118,981 acre feet, which contained I. 6 per cent of solids, or 8 per cent of mud by volume wet. Frequent observations were made, showing 20 per cent of silt by volume wet during the high stages of the stream, and in one instance 27 per cent was observed. The average amount of silt for the twelve months' observation was Io per cent by volume wet, and the amount of solids 2 per cent. No other stream in the United States is known to carry such a high per cent of sediment. This is in striking contrast with the clear streams of our northern forested basins. The water supply used for clomestic purposes from Cedar Creek, Washington, does not require filtering or settlement.

The serious nature of this silt problem can readily be appreciated by those who have studied the storage of water for irrigation. It is probably the gravest of all the engineering problems related thereto. Forestry 
should assist greatly in removing difficulties of this nature.

Mr. Marsten Manston made certain stream measurements on the Yuba River, California, for the Geological Survey. In an article, entitled "Features and Water Rights of Yuba River, California," Bulletin No. IOO, United States Department of Agriculture, in discussing the stream flow from certain portions of this basin, he makes the following interesting comparison between a forested and denuded basin. Both of these catchment areas are situated on the western slope of the Sierra Nevada, adjoin each other, and have exposures of marked similarity.

"On the south fork of the north fork we have a watershed area of I39 square miles, which was gaged on September 19, I90o, after three successive seasons of deficient rainfall, and gave a minimum run-off of I 3 cubic feet per second or 0.8 cubic foot per second per square mile. This area is well covered with timber and brush, and in one hundred and twenty days gives a minimum run-off of $1,44 I, 152,000$ cubic feet. The drainage basin of the north fork is more heavily timbered than the basin of the other forks, and consequently has a deeper soil, and although only one-tenth the total drainage area, it furnishes 75 per cent of the low-water flow of the entire drainage basin above Parks Bar.

"On the south fork, above Lake Spaulding, there is a watershed of I20 square miles, which has heretofore been described as comparatively bare of timber, and the timbered areas which once existed have been cut off. The run-off of this area is practically nothing for one hundred and twenty days each year, due to this absence of forests and brush. If this area were afforested and gave a minimum run-off of 0.8 cubic 
foot per second per square mile, the discharge would be roo cubic feet per second, or equivalent to $x, 036$,800,000 cubic feet effective storage capacity, a discharge more than equivalent to one-half the storage capacity of all the reservoirs above Lake Spaulding dam. These aggregate $1,375,000,000$ cubic feet, and the low-water discharge of Ioo cubic feet per second for one hundred and twenty days is equivalent to a storage capacity of $1,036,000,000$ cubic feet. As the basis of the above estimate is the extreme low-water discharge, it is safe to assume that by afforesting the watershed, this costly and extensive system of reservoirs might be safely drawn upon for double their present capacity. When this reasoning is applied to the entire I,357 square miles, instead of to small fractions thereof, the force of the argument becomes more apparent.

"It would appear from the foregoing that the solution of the problem of storage of flood waters is not in the retention of a small percentage of the storm waters behind dams, but in applying storage over the entire watershed by the systematic protection and extension of forest and brush-covered areas."

Professor James W. Toumey, a collaborator of the Bureau of Forestry, has selected certain small and adjoining drainage basins in the San Bernardino Mountains in a portion of the catchment area proposed to be utilized by the Arrowhead Reservoir Company. Throughout this area this corporation for a term of years has been making exhaustive hydrographic studies of the available water supply. A large number of rain gauges have been established and stream measurements are carefully made over weirs by skilled engineers. Automatic clock registering devices have been installed to give a continuous record of the flow at these various 
stream gauging stations. It is proposed to divert the water flowing from a number of these small mountain basins which are situated on the northerly slope of the San Bernardino Range by means of gravity canals and tunnels to the southern side of the range and into the San Bernardino Valley. This Arrowhead Reservoir Company has placed its hydrographic data at the disposal of the Bureau of Forestry, which organization made a forest study in connection therewith. The data that is presented by Professor Toumey is perhaps the most precise and definite information on the subject of related stream flow to forest cover that we have so far been favored with in the West. His conclusions, while they were to be expected, are gratifying in their definiteness. We can do no better than to quote from Professor Toumey in extenso:

"Because rainfall is most abundant where forests grow, many believe that forests exert an important influence on the amount of precipitation. A more reasonable inference, however, is that rainfall is the great factor in controlling the distribution and density of forests.

"Precipitation occurs whenever the air is suddenly cooled below the dew-point. The most effective cause of this is the expansion of air on ascending. This upward movement is caused very largely by cyclonic storms. Whether forests have any appreciable effect in cooling the air to below the dew-point is uncertain. From the known effect of forests on the temperature and relative humidity of the air, it is reasonable to infer that they may have some effect, at least to a small degree, and consequently that they have some influence in increasing precipitation. The present evidence, however, derived from many series of observations conducted in Europe and elsewhere, is so con- 
flicting that a definite answer to this question, having the stamp of scientific accuracy, is not possible.

"In a careful study of the behavior of the stream flow on several small catchment areas in the San Bernardino Mountains, it has been found that the effect of the forest in decreasing surface flow on small catchment basins is enormous, as shown in the following tables, where three well timbered areas are compared with a non-timbered one:

\section{Precipitation and Run-off During December, i899.}

$\begin{array}{ccccc}\begin{array}{c}\text { Area of } \\ \text { catchment }\end{array} & \begin{array}{c}\text { Condition } \\ \text { as to }\end{array} & \begin{array}{c}\text { Pre- } \\ \text { cipita- }\end{array} & \begin{array}{c}\text { Run-off } \\ \text { per square }\end{array} & \begin{array}{c}\text { Run-off in } \\ \text { percentage of }\end{array} \\ \text { cosin. } & \text { cover. } & \text { tion. } & \text { mile. } & \text { precipitation. }\end{array}$

Sq. miles.

0.70

Forested.

Inches. Acre feet. Percent.

1.05 Forested.

Igt

I9t

I. 47

Forested.

I9+

$36-$

$73^{+}$

3

.53 Non-forested.

I3-

$70-$

6

$312+$

6

40

"This is the stream discharge daring a month of unusually heavy precipitation.

"At the beginning of the rainy season, in early December, the soil on all four of these basins was very dry as a result of the long dry season. The accumulation of litter, duff, humus, and soil on the forest-covered catchment areas absorbed 95 per cent. of the unusually large precipitation. On the nonforested area only 60 per cent. of the precipitation was absorbed, although the rainfall was much less. 
Rainfali and Run-oFf During January, FEbruary, and MARCH, I900.

\begin{tabular}{|c|c|c|c|c|}
\hline $\begin{array}{l}\text { Area of } \\
\text { catchment } \\
\text { basin. } \\
\text { Sq. miles. }\end{array}$ & $\begin{array}{l}\text { Condition } \\
\text { as to } \\
\text { cover. }\end{array}$ & $\begin{array}{l}\text { Pre- } \\
\text { cipita- } \\
\text { tion. } \\
\text { Inches. }\end{array}$ & $\begin{array}{l}\text { Run-off } \\
\text { per square } \\
\text { mile. } \\
\text { Acre feet. }\end{array}$ & $\begin{array}{l}\text { Run-off in } \\
\text { percentage of } \\
\text { precipitation. } \\
\text { Per cent. }\end{array}$ \\
\hline 0.70 & Forested. & 24 & $452-$ & 35 \\
\hline I.05 & Forested. & 24 & $428-$ & 33 \\
\hline I. 47 & Forested. & 24 & $557-$ & 43 \\
\hline .53 & Non-forested. & I6 & $828-$ & 95 \\
\hline
\end{tabular}

"The most striking feature of this table as compared with the previous one is the uniformly large run-off as compared with the rainfall. This clearly shows the enormous amount of water taken up by a dry soil, either forested or non-forested, as compared with one already nearly filled to saturation. During the three months here noted, on the forested basins about three-eighths of the rainfall appeared in the run-off.

Rapidity of Dérease in Run-OFf After the Close, of THe RaINy Seison.

Area of Condition Pre- April May June catchment as to cipita- run-off run-off run-off basin. cover. tion. per sq. m. per sq. m. per sq. m. Sq. miles. Inches. Acrefeet. Acrefeet. Acrefeet.

$\begin{array}{rllrrc}0.70 & \text { Forested. } & \text { I.6 } & \text { I53- } & 66- & 25- \\ \text { I.05 } & \text { Forested. } & \text { I.6 } & \text { I46- } & 70- & 30- \\ \text { I.47 } & \text { Forested. } & \text { I.6 } & \text { I66- } & 74- & 30- \\ .53 & \text { Non-forested. } & \text { I } & 56- & 2- & 0\end{array}$

"The above table clearly shows the importance of forests in sustaining the flow of mountain streams. The three forested catchment areas, which, during December, experienced a run-off of but 5 per cent. of the heavy precipitation for that month and which 
during January, February, and March of the following year had a run-off of approximately 37 per cent. of the total precipitation, experienced a well-sustained stream flow three months after the close of the rainy season. The non-forested catchment area, which, during December, experienced a run-off of 40 per cent. of the rainfall, and which during the three following months had a run-off of 95 per cent. of the precipitation, experienced a run-off in April (per square mile) of less than one-third of that from the forested catchment areas, and in June the flow from the non-forested area had ceased altogether.

Annual Rainfall and Run-off on Forested and NonFORESTED CATChMENT AREAS IN THE SAN BER-

nardino Mountains, Caimfornia.

$\begin{array}{ccccc}\begin{array}{c}\text { Area of } \\ \text { catchment } \\ \text { basin. }\end{array} & \begin{array}{c}\text { Condition } \\ \text { as to } \\ \text { cover. }\end{array} & \begin{array}{c}\text { Pre- } \\ \text { cipita- } \\ \text { tion. } \\ \text { Inches. }\end{array} & \begin{array}{c}\text { Run-off } \\ \text { per square } \\ \text { mile. } \\ \text { Acre feet. }\end{array} & \begin{array}{c}\text { Run-off in } \\ \text { percentage of } \\ \text { precipitation. }\end{array} \\ \begin{array}{cccc}\text { Per cent. } \\ \text { 0.70 }\end{array} & \text { Forested. } & 46 & 73 \text { I } & 28 \\ \text { I.05 } & \text { Forested. } & 46 & 756 & 30 \\ \text { I.47 } & \text { Forested. } & 46 & 904 & 36 \\ .53 & \text { Non-forested. } & 33 & \text { I,I92 } & 69\end{array}$

"In conclusion, it may be said that although the forest may have, on the whole, but little appreciable effect in increasing the rainfall and the annual run-off, its economic importance in regulating the flow of streams is beyond computation. The great indirect value of the forest is the effect which it has in preventing wind and water erosion, thus allowing the soil on hills and mountains to remain where it is formed, and in other ways providing an adequate absorbing medium at the sources of the water courses of the 
country. It is the amount of water that passes into the soil, not the amount of rainfall, that makes a region garden or desert."

The drainage basin of the Sacramento River includes the greater part of northern California. It has been occupied by Anglo-Saxon settlers for the last fifty years. During the first portion of the American occupation of this State, sea-going vessels are reported to have proceeded up stream as far as the present city of Sacramento. The tidal range of the river was observed also at this point. Placer mining was the first industry. This work consisted in washing the oriferous gravels found along the western foothills of the Sierra Nevadas. The resulting debris was discharged into the streams and has to a very material extent filled their channels, so that to-day the head of tidal water is many miles below Sacramento, near the upper end of Grand Island, and only flat bottom river steamboats are able to ascend the Sacramento River as far as the city of that name. This stream condition has been still further aggravated by the destruction of extensive areas of forest, both by fire, lumbering, and sheep grazing. Yet the lumber industry is but in its infancy in this section, and plans are being perfected to cut down great areas of virgin forest. Extensive forest reserves have been provisionally set aside, covering most of the remaining timbered portions of the basin. These contemplated reserves have been greeted with a storm of public protest from central and northern California that has been hard to allay. In February, I904, northern California was visited by heavy rain storms. While the precipitation was great, according to the statement of Professor McAdie, of the Weather Bureau, it was by no means the heaviest rain which has occurred in this 
section, and it was one that could reasonably be expected to be exceeded in violence in the future. However, with the combined conditions of reduced forest cover and filled river channels, a flood condition was produced in the Sacramento Valley last February which has no known equal in the previous history of the State. Fully 800,000 acres of valley lands were submerged and the damages are estimated to have reached into the millions. All this is in spite of the fact that over twenty million $(\$ 20,000,000)$ dollars had been expended in the construction of levees to prevent these overflow conditions. A great State convention was called in San Francisco to consider the disaster that threatened the commonwealth. Eminent engineers have been brought to California from the lower Mississippi basin and elsewhere in the East to study this great overflow problem. Organizations have been perfected to urge, if not demand, both from the State and from the nation, relief from impending disaster. It is contemplated that a comprehensive levee system must be constructed the entire length of the valley at enormous expense.

What a beautiful assemblage of contradictions this situation presents to the forester! A great intelligent State with popular sentiment, at least in the injured section, set against the creation of forest reserves in this basin! The assemblage of conventions and engineers to devise plans to prevent flood overflow at a contemplated expenditure of millions. Doubtless with the channels of the stream in the condition that they now present a levee system will be required, but the greatest and most lasting preventative for these conditions would be the adequate protection of the forest reserves.

It may be stated that while there is no definite scien- 
tific information that forests increase rainfall, yet we have certain striking instances presented where the rainfall is greater on adjacent forested areas than on those that are denuded. At least in the arid regions it may be stated that the total annual output from a deforested drainage basin is greater than from a timbered area, but that the regimen of the stream is distinctly to the disadvantage of all who are interested in the use of the watered resources of the country, whether he be navigator, irrigator, or water-power investor. From the denuded area the floods are greater and the drought is more intense. To remedy this condition, one naturally turns to the storage reservoir for relief, yet even in this extremity one is confronted with adverse conditions. The violent flood from the bare basin rushing through the mountains carries with it eroded sediment, which it deposits in the first pool of still water that it encounters. The result is the reduction of the storage capacity of the reservoirs along its course. Forests are the natural and greatest storage reservoirs and regulators of water supply. On few streams do we find reservoir capacities even approximating the total annual output of the drainage basins above them. Accepting the facts as outlined above, the great importance of preserving the forests, particularly in the semi-arid regions of our country, is most manifest. In southern California, Arizona, and New Mexico particularly, we are so closely bordering on a condition of desert that when the forest is once destroyed the difficulty of reproducing it renders the task well nigh hopeless. We should, therefore, all join with the Bureau of Forestry in its effort to "save the forests and store the floods." 


\section{RIGHTS OF WAY IN FOREST RESERVES}

\section{BY \\ MORRIS BIEN}

Consulting Engineer, United States Reclamation Service

THE Forest Reserve Act of June 4, 1897, contains two provisions which affect rights of way within the reserves; namely, that actual settlers residing within the boundaries of the reserves shall for purposes of egress and ingress, be permitted to construct wagonroads and other improvements necessary to reach their homes and utilize their property, under rules and regulations to be prescribed by the Secretary of the Interior, and also that all waters on the reserves may be used for beneficial purposes under the State laws or under laws of the United States and the rules and regulations thereunder.

In the administration of the first of these provisions, for wagon-roads and other improvements, the General Land Office regulations provide for the construction of private wagon-roads and county roads wherever they may be found necessary and useful; no right, however, can be acquired upon the public lands for such roads as against the United States. No public timber, stone, or other material can be taken for the construction of such roads, without permission from the Secretary of the Interior, the application giving necessary details concerning the extent, location, and estimated value of the material to be taken.

The second provision, concerning the use of the waters, merely confirms the application to forest re- 
serves of the laws then existing, but did not make applicable to such reserves any laws which did not then apply to reservations. These laws were of several kinds, and provided for rights of way and for irrigation, electric and other purposes.

A subsequent act, approved February I 5, I90I, provides for right of way over forest and other reservations in general and certain national parks in California, for electrical plants, telephone and telegraph lines, canals and other water conduits for any beneficial use of water. These acts provide that the allowance of such rights of way within the reservations shall be subject to the approval of the department having supervision over them.

At the time of the passage of the Forest Reserve Act, there was no provision for right of way for railroads through such reserves. Consequently, it became necessary for each railroad company desiring to cross a reserve to obtain a special act of Congress, and during the years I898 and I899 several such acts were passed. In each of them was incorporated a provision, which was first inserted at the instance of the General Land Office, that no timber shall be cut by the railroad company for any purposes outside the right of way actually granted.

By the act of March 3, I899 (30 Stat., 1233), authority is given to the Secretary of the Interior to approve rights of way in the form provided by existing law, for wagon-roads, railroads, or other highways across any forest reservation, when in his judgment the public interests would not be injuriously affected. From that time on, there was no need for a special right-of-way act across a forest reserve.

Nevertheless, during the session of Congress in IgOI-2, a bill was introduced providing for right of 
way for the Central Arizona Railway Company through the San Francisco Mountains Forest Reserve in Arizona. In reporting upon this bill, the General Land Office referred to the legislation of 1899 , and stated that there was no need of such law, and that it would be better for application to be made in the regular way, subject to the general regulations in force. The bill was, however, passed without change, and was presented the President. At this stage, those interested in the matter, fearing that it would be vetoed, secured the passage of a resolution (April r2, I902; 32 Stat., I767), asking for the return of the bill. This was not done, but the bill was vetoed by the President April 23, 1902. At the next session of Congress a bill of an entirely different character was introduced. This provided simply that the company would be granted right of way upon compliance with the general regulations of the department. Such a bill was of no practical use, but it was not objectionable. It became a law February 25, I903 (32 Stat., 907).

Every application for right of way over a forest reserve for any purpose is reported on by a forest superintendent or supervisor, who is required to make a statement in detail upon every point affecting the interests of the government in regard to the preservation of the reserves.

A bond is required from the applicant that he will pay to the United States, for any and all damage to the public lands, timber, natural curiosities, or other public property on such reservation, or upon the lands of the United States, by reason of such use and occupation of the reserve, regardless of the cause or circumstances under which such damage may occur. Such a bond is required in every case except those of small importance, a definite limit being fixed in the regulations. 
The applicant is required, also, to file a stipulation that the right of way is not so located as to interfere with the proper occupation of the reservation by the Government; that no timber will be cut from the reserve outside of the right of way; that the applicant will remove no timber within the right of way, except only such as is rendered necessary by the proper use and enjoyment of the privilege; that he will also remove from the reservation, or destroy under proper safeguards as determined by the General Land Office, all standing, fallen, dead timber, as well as all refuse cuttings, etc., for such distance on each side of the line as may be determined by the General Land Office to be esesential for the protection of the reserve from fire; also that the applicant will furnish free of charge such assistance in men and materials for fighting fires as may be-spared without serious injury to the applicant's business.

With a careful scrutiny of all applications by forest officers on the ground, and a thorough enforcement of rules, regulations, and stipulations such as those indicated, it is believed that the occupation of the reserves for these necessary rights of way can be permitted without detriment to the Government interests.

The present laws relating to rights of way upon the public lands, as well as upon forest reserves, are such as to facilitate the operations of speculators to obtain, secure, and retain controlling points for the use of water for railroad, irrigation, power, and other purposes. The railroad and irrigation acts provide for a forfeiture at the expiration of five years from the date of location, but such forfeiture cannot be declared except by Congress or through courts.

Inasmuch as there are many thousand miles of railroad and irrigation rights of way which are now 


\section{AMERICAN Forest Congress}

subject to forfeiture, the declaration thereof by procedure in the courts is practically out of the question, except in a few specific cases where the interests of the public or of bona fide enterprises demand action.

It is important, however, for the proper development of the entire West, that these abandoned rights of way should be cancelled at the earliest possible date, for the reason that as soon as any bona fide enterprise is started, these rights, which are practically dead, are at once revived, and make enormous claims for the rights which they hold and which cannot be set aside without such delay as to seriously jeopardize the proposed development.

Congress should declare the forfeiture of all rights of way now subject to forfeiture, and authorize the Secretary of the Interior to declare the forfeiture of other rights already granted and to be granted in the future, upon the expiration of the time allowed for construction by the law.

This, however, would remedy only one feature of the difficulty. It would be just as easy, as the laws now stand, to tie up these rights, for five years at least, in the future. In order to meet this phase of the situation, it is recommended that a reasonable charge be made for the use of these rights of way upon public lands and forest reserves. This charge should be sufficient to deter the application for these rights merely for speculative purposes, and yet not so great as to interfere with future development of railroad, irrigation, and electric enterprises.

The time has now come when the value of these lands to the public is so great that their further disposition should be most carefully scrutinized. The great increase in recent years in the number of these applications shows very impressively the need of such safe- 
guards to protect the interests of the public in the future.

These considerations apply with particular force to the forest reserves, because no claim should be allowed to attach to lands within them except for actual use for public benefit, and it is exceedingly urgent that this Congress make a special effort to impress upon the Congress of the United States the necessity for immediate action along the lines indicated. 


\section{IRRIGATION CONSTRUCTION AND TIM- BER SUPPLIES}

BY

\section{ARTHUR P. DAVIS}

Assistant Chief Engineer, United States Reclamation Service

THE relation of scientific forest protection and culture to irrigation may best be discussed and appreciated by considering its importance to the successful operation of the Reclamation Act, which has become by the logic of events, the main exponent of irrigation development.

The broad object of that law is the creation under irrigation, of the maximum number of prosperous homes. These homes will depend in a great degree upon the forests, which are secondary in importance only to the supply of water and land.

The main reasons for the economic importance of the scientific culture and preservation of the forests, are the protection and regulation of the water supply, the preservation of the lumber industry, and the continuation of the supply of wood for fuel and numerous other domestic requirements. In all these the irrigator is intensely interested, and all have an important bearing upon his future prosperity.

The utility of the forest cover in conserving the water supply is generally recognized, and its importance is becoming more and more appreciated. The protective effect of the mluch of leaves and twigs, and the dark coolness of the forest shade, appeal to all as beneficial regulators of run-off, and preventatives of evaporation. Nor does it require scientific demonstra- 
tion to convince the settler of the importance to his welfare of a continued lumber and fuel supply. The great value to the settler and the settler's live stock, of the shade and shelter afforded by the trees of the forest and woodland are fully appreciated. Even the aesthetic and sanitary value of forests are not overlooked.

Related to the above is the influence of forests on irrigation construction. This may not be obvious to the average person, but the tendency of modern construction is to the use of the more permanent materials, less subject than wood to destruction and decay. This is facilitated by the development of the useful properties of concrete, iron, and steel, and their combinations. The Reclamation Service in particular is endeavoring to build, "not for a day, but for all time," and the wooden gate, the wooden flume, and other structures so much in evidence in the past are to be entirely superseded by more permanent materials.

To this end, massive gates of cast iron and bronze, set in abutments of concrete, are being introduced. Experiments have been made on reinforced concrete for use in pressure pipes and flumes, and the wooden dam is being superseded by that of concrete, masonry, or earth. To the same end the proportion of tunnels is increased, underground conduits being the safest and most permanent yet devised.

The effect of such a policy upon the consumption of wood is not, however, so great as might be supposed, especially in the construction period. The requirements for timber are still very great for piling and subaqeous structures to which wood is well adapted, and for buildings and the large class of temporary structures required on great irrigation works. No satisfactory substitute has yet been found for timber in 
tunnels and every structure of concrete requires wooden forms. So numerous and so great are the indispensable uses of timber in such works, that the existence of a supply of timber near a projected work frequently has an important bearing upon its feasibility and cost. Nor is this fact often appreciated fully. We are accustomed to estimate the utility of a lumber supply on the basis of its selling price, rather than of the cost of obtaining the supply elsewhere. For example, the cost of sawing and hauling timber to the point of use on a certain large project in the west is about twentyfive (\$25.00) dollars per thousand. Were it not for the small forest from which this supply is obtained, it would be necessary to import lumber from a distance at a cost of over fifty ( $\$ 50.00)$ dollars per thousand, and this represents the real utility of the local supply as a factor in the construction. It is not too much to say that the feasibility of some important irrigation works depends upon the proximity of ample timber supplies.

The development of irrigation will in the future lead to the rapid opening and development of timbered areas. which are now merely in their natural state. This fact emphasizes the necessity of placing the forests at once under the rigid scientific supervision of trained government experts. If left to the manipulation of selfish interests as in the past, the result will be lavish and wasteful use, and probably destruction of the forest. Every tree that will make lumber will be cut, the best parts hauled away, the branches and part of the trunk left on the ground to feed the fires that will soon follow and destroy all that the axe has left. Temporary profits will be reaped by a few, and the community will be robbed of its natural heritage. Eventually, the forest must be replanted and restored at enormous 
expenses of time and money, which can all be saved by a wise supervision without diminishing the present utility of the forest, nor destroying its future value, by merely protecting and fostering the tendency of nature.

Such policies of protection would have popular support, but the local communities have not the means, authority, nor skill to insure proper stpervision, which much be provided by the Government under the policy already proposed, the efficacy and wisdom of which has been so thoroughly demonstrated both at home and abroad. The policy that provided for present needs without mortgaging the future. 


\title{
FOREST AREAS OF CATCHMENT BASINS
}

(Impromptu Address)

\author{
BY \\ H. M. WILSON \\ United States Geological Survey
}

I AM very much interested in one feature of the discussion that has been brought before you to-day, and that is the relation of run-off from catchment basins to the forested areas of those basins. There is nothing new on this subject, however, which it seems to me I can bring before you. I heartily concur in the general opinion expressed by two of the speakers, Messrs. Lippincott and Davis, upon the effect of forests in regulating the discharge of streams and thus adding to their usefulness as providers of water for irrigation and upon the effect of this regulation in preventing disastrous floods which, by eroding the surface of the soil, carry vast amounts of sediment to the streams below and destroy both them and the surfaces which they erode. There are other features, however, of the subject of forest influence on water supply which are frequently noted in connection with the preservation of forests, which it might be well for me to qualify. We are familiar with the old-time claim of the effect of forests in increasing the rainfall and all of the foresters present who have looked into the subject, I am sure, believe now that whereas it is possible that forests may have some effect upon the amount of precipitation, there is as yet no definite information available from any source, either of experiment or investigation, which goes to prove it. And that feature of the subject of the effect of forests on water supply is one which I think the Weather Burean, or possibly the 
Bureau of Forestry, should have an opportunity to investigate in a way in which it has never as yet been investigated, so that we may learn positively if there is any such effect; and it is not a form of investigation that is difficult to carry out. It has been attempted in haphazard ways over limited areas in Europe, but never by the wholesale method of detailed regional study.

There is another feature of the subject that occurs to me, and that is the claim not infrequently made that forests increase the discharge from streams, and that claim is also not infrequently put forward by overzealous friends of forestry. And that, too, may be correct, though from any investigation or any research yet made into the subject I fail to find that there is any clear evidence that forests do increase the amount of water available for discharge by streams, and for the uses of man. And that is another investigation which might readily be undertaken in this country by the proper Government officials or others and thrashed out to a definite conclusion, and which might react very favorably upon the subject of forest preservation. I can conceive now that the Reclamation Service or the Hydrographic Branch of the Geological Survey, over which $\mathrm{Mr}$. Newell presides, might undertake such experiments as those of Professor Toumey, of the Bureau of Forestry, which Mr. Lippincott illustrated here in the upper diagrams. I can conceive that $\mathrm{Mr}$. Newell's bureau, with the facilities that it has, might readily be encouraged to take up the question of the discharge of streams from forested and from nonforested areas of like conditions and show what Europeans, the people of India, and older countries interested in forestry, have not yet been able to show, whether or not forests have any actual effect in increasing the water supply. 


\title{
FORESTS AS A FACTOR IN SHAPING THE PHYSIOGRAPHIC FORM OF MOUNTAINS
}

\author{
BY \\ J. W. TOUMEY
}

Professor of Forestry, Yale Forest School

THE effect of forest cover upon the surface flow of water has been for many years an inviting field for speculation and research, both in this country and abroad. Since the extended researches of Ebermayer of Bavaria, more than a quarter of a century ago, most writers in this field have placed special emphasis upon the effect of forests in providing a larger and better absorbing medium. It has been argued that the chief influence of the forest upon the flow of streams, lies in the fact that it provides a looser and deeper soil, covered with a variable depth of humus and litter, into and through which the precipitation freely seeps. Therefore, a much larger part of the rainfall is taken up by forest soil than by soil in the open, and there is less to pass directly into the streams by flowing over the surface. As a result, the flow of streams in for ested regions are more sustained than similar strea" flowing from naked drainage basins.

There is at the present time no serious opposition to the view as here set forth. In recent years, however, special emphasis has been placed upon the following, viz., that the proportion of the rainfall that reaches the streams and the manner of its reaching them depends chiefly upon the physiographic features of the 
region. The contention is made that when other conditions are similar, it is the physiographic form which most largely determines the amount of run-off in proportion to the precipitation and the fluctuations in stream-flow as well.

I wish to emphasize the fact that the physiographic form of the drainage basin, more particularly those features which most largely influence stream-flow, have been brought about by forest growth acting through long periods of time.

In checking wind and water erosion at the sources of our mountain streams, the forest produces a much greater effect upon physiographic detail than generally recognized. On the summits of mountains and on ridges, where the forest has a density of .8 or greater, and where the forest floor has been undisturbed by fire and grazing, the wealth of litter, humus, and mineral soil takes up practically all of the precipitation; which, seeping through the soil, reappears on the surface at lower elevations without bringing silt and other eroded material with it. Erosion, therefore, in such regions is very slow as compared with non-forested regions.

Vertical corrasion in the channels of the intermittent and permanent streams is also a slower process, because there is but little grinding material carried by the moving water.

On the other hand, when summits and ridges have been without forest cover for long periods, there is not only an almost total absence of litter and humus, but a scant covering of mineral soil as well. The absence of an absorbing medium causes the larger part of the rainfall to flow over the surface from the place of falling. This surface flow causes rapid erosion.

The forest, in preventing the transportation of soil 
at the sources of mountain streams, ultimately brings about a very different physiographic configuration from that of non-forested areas under otherwise similar conditions. In well timbered mountain summits and ridges are usually broad and rounded. On the other hand, non-timbered summits and ridges are inclined to be sharp and jagged, with very precipitous slopes. The former have a convex physiographic form, while the latter have a concave. This condition can be observed in all the mountain ranges of the West. Even in the same range, these features above or below timber line have sharp ridges and concave lines, while in the dense timber the ridges are rounded and the form is convex.

I am well aware that convexity in physiographic form is indicative of youth, while concave physiographic form indicates age. Although in a broad way this is true, the concave or old type is reached at a comparatively early age on elevations that do not bear a forest cover, while it is almost indefinitely postponed on elevations that sustain an uninterrupted forest growth.

The convex configuration of forested summits and ridges is the ideal type for the retention of a maximum amount of the precipitation on the higher portions of the drainage basin to ultimately seep through the soil and give the streams a sustained flow.

The concave configuration, which is so characteristic of non-timbered mountains, permits the precipitation for the most part to escape over the surface, not only on account of the absence of an absorbing medium, but because of the more precipitous slopes.

The former condition causes a large percentage of the rainfall to be retained at high elevation from whence, through seepage, it gives perennial flow to mountain streams. The latter condition results in the 
greater part of the precipitation rushing over the surface to lower levels. Only a small percentage of the rainfall is retained at the higher elevations, hence there is but little seepage to feed the streams and they become dry soon after the flood waters subside.

I cannot here enter into the various observations and researches made under my direction during the past four years, which bear upon the relation of forest cover to stream flow. These investigations and the conclusions which they appear to warrant are soon to be published in bulletin form by the Bureau of Forestry, U. S. Department of Agriculture.

The single point that I here desire to emphasize is this: forest cover in mountain streams, through its influence upon erosion, has a very appreciable effect upon physiographic form, and this effect of the forest working through long periods of time, is of the utmost importance in its influences upon the flow of mountain streams. 


\section{PART III}

THE LUMBER INDUSTRY AND THE FORESTS 



\title{
THE LUMBERMAN'S INTEREST IN FORESTRY
}

\author{
BY \\ N. W. McLEOD
}

President, National Lumber Manufacturers' Association

$\mathrm{S} \mathrm{UCH}$ an assemblage as the one before me would have been quite impossible ten years ago. The lumberman and the forester were then far apart. So long as forestry was regarded as merely scientific, but little progress was made; but as it came largely through the influence of our Bureau of Forestry, to be more clearly understood as a musiness matter, the prospect has brightened rapidly. The very fact that this American Forest Congress has assigned one session of its meeting to the discussion of the lumber industry and the forests is excellent evidence that the development of forestry is in the right direction. And in developing an American system of forestry founded upon sound business principles and adapted to local conditions, the Bureau of Forestry is doing a very important work.

For a number of years at the annual meetings of the various lumber manifacturers' associations, the Bureau has been represented by some well equipped member of its staff, who delivered an address of interest and value to practical lumbermen. The Bureau has in a large measure succeeded in convincing the lumbermen that forestry is not antagonistic to the lumbermen's interest, but in line with it. At present while forestry is accepted tentatively, the individual is backward about inaugurating an innovation in his 
own operations, as any plan that requires years to prove profitable; the commercial mind is slow to embrace.

The facts that must deeply impress the individual are those which influence matters of personal interest. The lumberman centers his attention on that part of the forest which he can profitably convert into money. The young, immature trees are obstacles to him, which increase the cost of transporting timber to the mill.

$T H$ : forester, on the other hand, considers young trees as the basis of future returns.

In order that the best results may be obtained, the forester must understand the economic problems that confront the lumberman. The manufacturer of lumber faces the necessity of providing raw material (standing timber) for from five to twenty years, depending on the size of his plant, in order to justify his investment. He usually has maturing payments on his timber land, that have to be met from the returns of operation. This necessity has generally precluded in the earlier years of a lumberman's operation serious consideration of anything but the production of the lumber at the lowest possible cost. The practice of forestry would increase the cost of production per unit on account of the less amount of timber immediately available from a given area. The percentage of increase in cost of production would be very slight where there is a heavy stand of timber, but in a light stand the percentage of increased cost would be quite large. The individual operator has always had to consider-first, the necessity of employing a larger investment; second, competition of manufacturers, who are operating regardless of the principles of forestry. This competition during periods of general commercial depression might force the manufacturer 
who is practicing forestry to run his plant at a loss, or suspend operations until the conditions of supply and demand were favorable.

About two years ago a number of gentlemen who were large holders of timber lands made an effort to consolidate practically all of the larger yellow pine holdings of the South into a single timber company, contemplating the cutting and sale of timber to lumber manufacturers under the application of forestry. That is, that the amount of timber in one year should not exceed the amount produced, except where the land would produce greater returns as agriculture, when it would naturally be cut clear. If this plan could have been put into operation, the increased cost of transporting the mature timber over larger areas made necessary by the application of forestry, would have been more than equalized by the advance in the value of stumpage, on account of the smaller amount immediately available.

It was found, however, that the general public, as well as many timber owners, did not understand forestry sufficiently well to look favorably upon an investment of either capital or timber on the scale proposed.

A meeting such as this gives promise that the forester will increase his knowledge of economic problems before the manufacturer, and that investors and holders of timber learn that the forester does not desire to place obstacles in the way of profitably converting the forests into lumber, but by forestry to protect them from fire, disease, and useless waste, thus making forest investments safe and permanent.

That forestry is practicable upon large timber holdings, either in private or Government ownership, is unquestioned by all who have given the matter careful 
thought. Lumbermen who have studied the timber situation realize that in the future, as in the past, the largest returns will not be obtained through their manufacturing plants only. The great fortunes that have been made in the lumber business have been acquired by the owners of large bodies of timber lands, and this condition will continue. For the purpose of illustration, let us consider the supply of timber as represented by one circle, and the annual consumption by another circle. The circle representing consumption is annually increasing, as the result not only of increase in population but of a material increase in per capita consumption of wood.

On the other hand the circle representing supply is annually decreasing, and unless the forests are reserved for use, instead of being sacrificed for the sake of the cost of immediate production of lumber, the circle of supply, as far as it can be considered a commercial factor, must disappear. If this be true, all Government timber lands should be withdrawn from sale or entry and placed under conservative forest management, all mature timber being for sale, provided proper protection is given the young timber. In this way, at least, a partial supply of timber for future generations can be perpetuated. 


\title{
THE CHANGED ATTITUDE OF LUMBER- MEN TOWARD FORESTRY
}

\author{
BY \\ J. E. DEFEBAUGH
}

Editor American Lumberman $\mathrm{R}$ ECALLING the history of the lumber industry of
America and of forestry in this country, we are filled with mingled emotions of pleasure and surprise as we attend the sessions of this Congress and behold the character and diversity of this assembly. It reminds me of the story told by Dr. Henry Van Dyke of the little girl who asked her father:

"Papa, where were you born?"

"In Boston, my dear," he answered.

"And where was mamma born?"

"In San Francisco, my dear."

"And where was I born?"

"In Philadelphia, my dear."

"Well," said the little one, "isn't it funny how we three people ever got together!"

There are present, through the most altruistic motives, not only men to whom forestry is a science and an occupation, but men whose business is the cutting of the forest, and men who are neither lumbermen nor professional foresters, but who occupy high places in our national life and are interested in the forestry movement because it is for the national good.

There is to participate in the proceedings of this convention the most distinguished forester in the nation 
and consequently the most distinguished forester in the world-the President of the United States.

To him who in the love of nature holds

Communion with her visible forms, she speaks

A various language-

and Theodore Roosevelt has held communion with nature possibly more extensively and certainly more intensively than any of the rest of us here. He has learned to know nature, and consequently the forests, from their romantic and practical sides, and he has demonstrated his practical sympathy with the forestry movement as has no other in this country.

Another high forester, who has been an efficient stimulus to forestry and along effective lines, is the President of the American Forestry Association, the Secretary of Agriculture, James Wilson. Of him Senator Mark Hanna, the sincerely lamented statesman from the Buckeye State, said to a great audience of lumbermen assembled in this city two years ago:

"'Uncle Jimmy' knows his business and he has taught the people of this country on the farm, in the forests and in the mines - all of the great productive interests of the United States-more in the five or six years he has been at the head of that department than all the rest of the scores of the departments put together. $\mathrm{He}$ is the right man in the right place. And it makes no difference what changes may come in the political atmosphere here, we will keep him here if we have to run him on a separate ticket."

Another forester among us, of national reputation, and a fame peculiarly his own because his work has been and is largely altruistic, has given a large percentage of the present impetus to forest work-Gifford 
Pinchot, the chief forester of the Government. A man of culture, he has decided to make his life work one for which not only the present but future generations will "rise up to call him blessed."

All within sound of my voice, therefore, are foresters; and so I feel some confidence in a kindly reception of this effort. The subject has been a cause for comment, not only in the lumber trade but among all interested in forestry: "The Changed Attitude of Lumbermen Toward Forestry."

I think, however, it is hardly adequate to assume that only the lumberman's position has changed; the change has been as great, or greater, in the conditions surrounding us, and in the attitude and policies of specialists in forestry.

No reasonable man would be disposed to denounce the early settlers of the timbered portions of North America for cutting away the forests. Cleared land was necessary for the growing of food products which were essential to the sustenance of life. A man with a family, by a courageous enterprise or by the force of circumstances projected into the wilderness, would not hesitate to cut down and clear off the tree growth as rapidly as his strength permitted. Self-preservation is the first law of nature, and the pioneers in our forest areas had to clear the land or starve. Moreover, in the early period of settlement he was considered the greatest benefactor to the state and to the community in which he lived who slashed down the most forest and cleared the land most rapidly and thoroughly.

At first there was no thought of the future value of timber; at the moment it was a cumberer of the ground, like ledges of rock and the loose stones of the glacial drift. It was thought to be a fortunate possibility that a portion of the cumbersome forest growth, 
that must be cleared from the land anyway to make room for towns, villages, highways, and farms, could be utilized. In the process of clearing farms, if any of the timber could be sold and shipped to the European and seaboard markets or used for local improvements it was a clear gain, profit accruing from a gratuitous resource, like game from the woods or fish from the waters. There was no thought that the trees would in time acquire a distinct and appreciable value simply because they had become scarce.

Another reason why the early lumberman from his own viewpoint saw no particular value in standing timber was that he found it hard work to make a profit when he had an unlimited privilege to cut all the timber in sight. In the beginning of operations in the three northwestern white pine states-from 1830 to about 1845 -all the mill operators had to do to secure logs for sawing was to obtain from the Indians the privilege to cut timber, which permits were usually sanctioned by the Government. A few goods given to the Indians were sufficient to secure all the logs necessary to supply any of the mills of that day. Timber that would run 60 per cent uppers could be secured in exchange for whiskey that would run 90 per cent adulteration.

The early operators penetrated the deep woods far from settlement, going along the lake shore and up the rivers 100 or 200 miles from any considerable base of supplies, and after great hardship and excessive labor, and often loss by flood and fire, managed to saw a little lumber in the primitive saw mills of that day and raft it out to the market. It goes without saying that these early operators had no thought for the preservation of the forests. They took the nearest and best trees for their purpose, as they needs must if they were to make any profit in their enterprise. 
After the pine lands had been surveyed and settlement had developed a general demand for lumber, pine holdings began to have a specific value-but at first it was a acreage price at Government figures. It was cheap property and so esteemed. The main thing with the lumberman was the expense involved in building mills, in cleaning out streams for the floating logs, putting in camps, and all else that was involved in logging, milling, and marketing.

As to pine stumpage, the mill operators from $185^{\circ}$ to I880 thought there was no limit to it. Its possible exhaustion was considered so far in the future as to be a negligible quantity in the equation. The location of a mill at an advantageous site for floating logs down to it and for shipping lumber when produced was the prime consideration. The investment was in these things; the value of the raw material on the stump was the minor factor in the problem.

And yet with stumpage worth but $\$ \mathrm{I} .25$ an acre lumbermen found it difficult to make profit in their business from $\mathrm{I} 850$ to $\mathrm{I} 857$, and, in the latter disastrous year and the several years following, hundreds of them in Michigan, Wisconsin, and along the Mississippi River went to the financial wall. After the civil war there was a revival, with some few successes and some slight increase in timber values. In I873 came another financial revolution and more depression in the lumber business, accompanied by many bankruptcies.

Not until I879-80 did the northern pine business reach a plane of commercial activity where stumpage values began to be considered. At that time the pine owners who had hung on to their stumpage despite hard times, low prices, and meager profits in lumber production began to realize that they possessed wealth in their pine trees. Then standing pine began to be 
closely estimated and the value of an acre of land was determined by the number of thousands of feet of logs that could be cut from it. But, as in nearly all cases where their is an advance of stumpage values', there was not a commensurate rise in the value of sawed product. Operators with large holdings of standing timber were made rich by the advancement in the value of their stumpage, while they found it necessary to pursue the strictest business methods and use the most economical appliances in order to produce lumber at a profit on the basis of stumpage values. Consequently there followed the utmost utilization of the pine on a given area of land. As the years passed standing pine continued to advance in price in greater ratio than sawed product, and the effort to convert every possible tree into salable lumber increased. A great change was induced, a change from the old method of cutting all the larger trees and those nearest the water, as was done in the '4os and '50s, to the latter-day practice of scraping the land of every tree that would produce mechantable lumber, down to those that would turn out only a $4 \times 4$, with possibly bark on one or more corners of the piece. Sometimes have been cut in this way trees whose product would not pay the saw bill. Yet there was produced from them a product useful to the community at large which from the lumberman's point of view would have been wasted had they been left in the woods, and his natural desire for thrift and economy led him beyond the point where his operations would result in profit to himself.

The development of railroad logging has also had its notable influence in this direction. The expense of building logging railroads into the timber is so great that only comparatively solid bodies of timber will carry it. When the merchantable timber is taken out 
the road is also taken up and moved elsewhere; and it is desirable that before this is done the logging shall be thoroughly completed. Under such conditions it often is very unlikely that even if the smaller trees be left upon the tract there will ever again be a sufficient stand of timber to justify the rebuilding of the logging road.

The point aimed at in this cursory review of the evolution of the pine lumber industry is to show that the lumbermen all along pursued a strenuous course in their endeavor to make a profit in their business. In their enterprise they had to be pioneers in a vast wilderness; they had to cover wide extents of territory in carrying out their plans; they were forced to clear out streams, build dams, put in booms, erect mills, and latterly construct railroads, build and purchase vessels, equip lines of barges, and establish docks-all of which required capital and necessitated great economy, business acumen, and thoroughness in order to secure profit in operation. It was a business that required much money and credit and considerable time before any profitable results could accrue. Is it any wonder, then, that the lumbermen looked upon their stumpage, or any stumpage, as merely raw material from which, if conditions were favorable, they could extract a money profit?

Fifty years ago in this country a general application of forestry methods would have been absurd. There were some cases where forests in particular places should have been preserved, but up to that time and even later the forest as a whole was an encumbrance. -In the eastern part of the United States, which had the people, not only the lumberman but the settler also was engaged in removing the forest, with the difference, however, that the settler was making little or no use of it, but merely destroying it to get it out of his way. 
Modern civilization cannot exist in the shade nor live on mast. The forests had to be cleared away in order to give place for growing corn and wheat. So there was the peculiar combination of dependence upon the forests for fuel and building supplies and at the same time the obligation to remove them to make room for other crops. The lumberman, therefore, was not a devastator, but performed a useful function in the community at a profit to himself by removing that which had, as it stood, little or no value. The public cannot with justice condemn the lumberman for chopping down the trees when it recalls the conspicuous example set by the Father of his Country.

Furthermore, until recent years the Government, which owned the forests in the unused areas of the United States, placed no special value on them. It invited acquisition by any one, including the lumberman; consequently the lumbermen came into possession of much of the-timbered area and practically all the pine, hemlock, and similar woods which grow in solid forests. There was thus set up a property interest which had to be treated like any other private interest. Many had their fortunes invested in timber and the only way in which they could realize on the investment was by manufacture.

It is true that with recent years standing timber has come into greater prominence as an opportunity for investment, and there are now large holdings in the hands of capitalists who have never owned nor operated a saw mill and perhaps never expect to do so. Such owners hold their timber for an enhancement of values as would an investor in real estate, but they expect to hold only so long as it seems more profitable to hold than to sell. They are not holding their timber for posterity, but only for the best marketing oppor- 
tunity. The same question of present versus future markets confronts the timber owner who is also a manufacturer, modified somewhat by the inclination to keep the mill in operation. It determines somewhat the capacity of the mill to be built upon a given site with a known amount of tributary timber, and after it is built determines whether the output shall be restricted or pushed to the limit according to the current market demands. That is the point of view of any other owner of pine timber or of any other sort of timber that has tangible value. The tree represents a definite asset to be converted at the earliest favorable opportunity, and without reference to any possible interest that posterity might have in its being permitted to remain on the stump.

The increase in value of all timber holdings within recent years makes advocacy of forest preservation, as far as merchantable timber is concerned, properly a plea for so managing the forest as to get the greatest amount of commercial product from it at the present time without impairing any more than necessary its productive capacity for the future. The holder of a timber estate is actuated by exactly the same considerations as the holder of other property-he wishes it to produce more money than he has put in. If he can be convinced that the timber is such that its growth will give him greater earnings on his investment than its cutting at the present time he may be induced to hold it; but he is not likely to let his forest stand solely for the benefit of posterity, or unless it is practically shown that this procedure will lead to enhancement in the value of his estate. In so far, however, as the timber is already matured the time of its harvest is already at hand. The owner, of course, desires to harvest it in the most economical manner; and if 
timber owners and lumbermen can be instructed in this particular and induced to practice timber management in accordance with the plan advocated by trained foresters much will be accomplished in the direction of prolonging existing timber supplies. But it should be admitted by everybody that the money value of standing timber will inevitably determine the disposition of it, except where it has been reserved by the Government.

If there has been any tardiness in recognizing the necessity for forest regulation and reforestation it should be understood that the forestry idea has been slow in gaining ground even with a disinterested general public, a fact chargeable neither to the lumbermen nor to the forestry advocates.

We have heard much of the "wasteful methods" of the lumbermen, but in the early days of lumbering there was no waste that was not necessary, or, rather, no waste that was not more economical than to save. No property owner can afford to spend dollars when he will receive only cents in return. Under the conditions, the waste in tree tops, tall stumps, thick slabs, edgings, and trimmings and much sawdust was, from a financial standpoint, no waste at all. The lumbermen did with their property only what would yield the best returns.

To an industry established on such a basis there came the advocate of forest preservation. Originally -during the early agitation of the subject and up to within fifteen or twenty years - forestry advocates were manly of two classes, either sentimentalists or technicists; the latter being trained in the forest methods of the old European countries where conditions were entirely different from those that obtained in the United States. The former scolded or tearfully implored, while the latter proposed the impossible, 
Listening to the abuse that was showered upon them; to the seemingly impracticable theories; to the petitions which, if granted, would have wiped out their properties, is it any wonder that lumbermen were at first indifferent or even were aroused to hostility? Some of them were incensed, others threatening, and others were amused by unjust criticism.

Beware the wicked lumberman, That wasteful, hasteful artisan. But while the logger you discuss A glance take at the rest of usThe camper with his cheery blaze That blows around in many ways; The hunting man with pillar bright Of smoke by day and fire by night; The farmer with his log heap high, His stump-fire when the weather's dry, His fancy, solid walnut fence$\mathrm{He}$ worries not about expense. $\mathrm{Oh}$, when the logger you condemn Consider well the rest of them. Consider the farmer of the field Who loves the flaming torch to wield; The campers toil not, neither spin, Yet pretty blazes they beginNor Solomon, in all his ease, Burned money up like one of these!

However, a change in conditions was going on. Up to the point where the natural growth of the forest would more than take care of the needs of a community the surplus was valueless and would better be disposed of in some manner than preserved at any material cost. But when we reached the stage where the forests were 
reduced to the point where the natural annual increase would not more than take care of the present and prospective needs of the country, then values advanced and the lumbermen have come to see some practicality in the proposition that methods of forest preservation should be introduced.

Like all methods that effect great changes in society or economics, the forestry idea in the United States has been an evolution. It must be confessed that foresters of the present day discard some theories that were considered important by American forestry experts of thirty years ago.

There's that dear old rainfall theory once held in such esteem

By which a dampness was produced by such a simple scheme.

As Aaron smote the rock of old and found a water power

So might we plant a tamarack and start a summer shower.

Behold the forester of old, the optimistic fellahA planting trowel in one hand, in the other an umbrella.

Our duty is not particularly to refrain from chopping down trees ripe for the ax ,but to be active in replacing them. Coincident with this duty is that of cutting only mature timber, where that is possible, and of guarding timber tracts from fires and other destructive agencies that often are due to carelessness.

There is nothing truer than the old saying that you cannot eat your cake and have it, yet it never restrained very many people from eating the cake, for the cake must be eaten to be enjoyed. The thing to do is not 
to weep over the cake after it has disappeared, but to get out the recipe book and make another.

No one will question the soundness of the lumberman's belief that his method gets the greatest use out of the tree. Though the old theory is now seriously questioned if the standing tree encourages the summer shower, the sawed shingle is necessary to protect the head of the man from the thunder storm. Nothing in the world can suffer a better fate than utilization. When the tomato was the ruddy "love apple" of our youth it was a beautiful object, but who will deny the more potent attraction of the tomato stew? We are compelled to admit that the mature tree must come down. Once down, that particular tree is eliminated. I am reminded of the question asked of the Swiss guide by the tourist. He was gazing over the edge of the precipice and remarked to the guide: "I suppose people often fall from here?" "No," replied the guide, "only once." A tree is felled but once and the next and only thing is to replace it where that is practicable.

That there has been a change of heart within recent years on the part of American lumbermen toward the forestry idea there can be no doubt. If you should ask me to what $I$ ascribe this sentiment I would say that the most important step forward was made by the disciples of forestry when they ceased to preach the doctrine of indirect and deferred benefits and began to demonstrate that direct benefits could be made to result from forestry as a science and as a practice. Proper forestry regulations and successful reforestation can never be brought about except by a demonstration of direct results. All that has been said about the influence of forests on climatic conditions, on watersheds, bird life, etc., may be, much of it is, absolutely true, but the great and vital question that appeals to the 
American lumberman is: "How can I cut my timber now and at the same time grow a new timber crop for future supply?"

Inasmuch as my intereest in the forestry movement began contemporaneously with my identity with the lumber press, many reminiscences occur to me in connection with the subject which time does not permit me to indulge in; but I do not know that I could better illustrate the progress which has been made during the last decade than by giving a few brief excerpts from an address which I made upon this subject during the proceedings of a forestry congress at Chicago in the summer of 1893 , arranged by Hon. W. I. Buchanan, chief of the Forestry Department of the World's Columbian Exposition. Regarding the attitude of the lumberman at the time, I said:

" $\mathrm{He}$ is as heartily in accord with all movements looking toward the welfare of the coming generation as any one can be who *** has to make his living in this. *** Talk to him as a citizen or a philanthropist and you at once gain cordial attention and arouse his interest in a way, which as far as the exigencies of his business will permit, will be reflected by his actions, but as a lumberman he is face to face with the hard actualities of life. He sees the practical side perhaps all too plainly, but that practical side cannot be ignored. The present is an overpowering fact, while the future has but a shadowy influence."

In that address I referred to the then almost irresistible incentives to the employment of lumbering methods wasteful from the standpoint of the forester but inevitable in the stress of competition, and admitted our absolute dependence for forestry results upon governmental control. Upon this I said in part:

"The lumberman will have no objections to govern- 
mental regulations which shall require him to clear of the debris remaining therefrom the land on which he conducts his logging operations; but he would insist that such regulations shall be $* * *$ applied impartially to all sections, as otherwise an artificial inequality would be brought about. State regulations will hardly answer, for stringent enforcement of rules in Wisconsin may put the operator in that state out of competition with his competitor in Minnesota or Michigan. * * *

"This the Government can do: It can refuse to sell or give up control of timber standing on Government land. It can perhaps, even now, gain some small revenue from allowing timber to be cut under proper restrictions, for which a royalty shall be paid. *** It is possible that the Government might purchase standing timber so located that its preservation might have some marked effect on the watersheds and natural reservoirs of the country, but it is doubtful if even this rich nation could do much in this direction."

What the Federal Government has accomplished since that time in the establishment of forest reserves and in arranging for the lumbering of the mature timber from certain of them under forestry regulations is a matter of history. It is to be regretted that thus far no attempt has seemed feasible to compel the cleaning up of forest debris in lumbering operations upon private holdings. Such a law universally enforced would effect a decreased loss through forest fires which would more than pay the increased cost of operation.

Regarding the application of forestry methods to lumbering I said at that time:

"What is wanted is a commercial conservation of the forests, but this involves conditions so different from those now prevailing that it is difficult to see 
how any immediate headway can be made. But agitation for anything theoretically desirable is a good thing, for the dream of one generation is the reality of the next. Conditions are shifting fast in this new country of ours and the next fifty years are likely to show great changes in fundamental things.

"The time is comparatively near at hand when the virgin wealth will all be exhausted or closed to the pioneer, and when the conservator must take the place of the developer and promoter. It is therefore not too soon to begin the study of this important subject of forestry, as perhaps before we are aware of it the conditions may have so changed that what now has its existence only in theory may have been materialized into concrete form."

During the eleven years that have passed since that time the cause of forestry has made great headway under the intelligent direction of the Bureau of Forestry, although that bureau has been until very recently handicapped by a division of its natural duties between three branches of government lacking intelligent centralized control. It has, however, brought the practical and the theoretical into more harmonious relations with each other and has promoted a broader and deeper understanding of all the elements which enter into the problem and has prepared all of those who are interested in the subject for effective co-operation. What has been accomplished is much; it is hardly more than preliminary and preparatory for the actual work of the next decade.

I want to call your attention to the fact that the inhabitants of great timber states have not been unmindful of this question. They have viewed with concern the rapid disappearance of their woods, and have to a large degree come to a realization of the 
serious meaning of the annihilation of their forests. Neither are the men who are engaged in the lumber industry unmindful of the seriousness of the situation. Within a few years there has been a marked change among lumber operators in this respect. This has come about largely because of the increased wealth and intelligence of the mer who now control a large percentage of the merchantable timber of the country. Lumbermen in the old days struggled for a mere existence; in these modern times many of them have emerged from the status of the pioneer to that of the well-to-do business man; many are legislators, nearly all are men of affairs in other lines than lumber, and in point of intelligence and broadness of view they rank with any other class of people in the country. It is impossible that such men should not realize the importance and benefit expressed in the term "forestry." They are in favor of forest reserves, properly administered, in certain portions of the country where such reserves will do the most good. They indorse the wisest and most thorough economy in the management of their own forest holdings. They would be glad of any plan for economical cutting and marketing that would be an improvement on present methods. Indeed the tentative efforts that have been made in these directions by owners of yellow pine stumpage in the south prove this. These owners have seen how northern pine has been slaughtered to near exhaustion and wish to avoid such a precipitate, headlong rush toward the end.

The fact that there was in the past season almost unanimous coöperation among yellow pine manufacturers, and is now among Pacific coast producers, to curtail the mill output to coincide with the actual demand, shows that there has been an awakening to the evil of sacrificing timber by forcing the sawed 
product on the market to the extent of breaking down values and causing unprofitable prices. It is true a commercial motive enters here to prevent the slaughtering of the forests, but the result is the same. In one sense there are no purely unselfish motives touching economical questions. Even the disciples of forestry wish to preserve, propagate, and perpetuate the forests because the results would be of economic benefit to mankind. The underlying motive is the benefit that largely can be expressed in dollars and cents. So it is an encouraging sign to see the lumbermen awakening to the fact that it is to their individual interests and to the interests of their heirs to make the most of their timber by the prolongation of cutting and by the preservation and nurture of the young growth. In this awakening they are in direct accord with the most advanced forester. Moreover, it can be said that the present spirit of the lumbermen in respect to forestry is but a foretaste of what it will be as the years pass. Forestry is a cause that shall grow in earnestness and power until it shall have become the undisputed dictum as applied to the management of the woodlands. In saying this I believe that I voice the faith that is growing in the minds of intelligent lumbermen.

Let it not be supposed that the lumberman is any less public-spirited, any less a sentimentalist, than he who is engaged in any other line of business. He sees as much beauty in a noble oak or elm as does any one. He would preserve nature's landmarks if he did not have to pay all the cost himself. He sees the value of a forest cover on the mountain slopes and at the head of the waters of the streams. He sees all these things but he does not wish to pay, himself, the entire cost or more than his fair share of the cost. His attitude toward forestry has changed with the conditions, and, while there may be exceptions, the average operating 
lumber manufacturer is disposed to show the Government that he will be satisfied (if the Government will hold and care for the forests), with buying from the Government the surplus timber.

I could paint a glowing picture of the great interest that has been aroused in forestry, augmented by the individual work and advice of the Bureau of Forestry and its able and efficient head, Gifford Pinchot; but I surmise that you want a true picture of actual operations and to know to what extent they conform to accepted forestry practice. I wish I were able to report that 90 per cent of the lumbermen of the country cut their timber in accordance with rules supplied by Mr. Pinchot and his assistants. It would be gratifying to me to say that 75 per cent did this; that 50 per cent did! that 25 per cent did. Throughout the country from the Atlantic to the Pacific from the Lakes to the Gulf, I find but a few isolated cases, and most of these of comparatively recent origin. Why? Because heretofore it has not been practicable. While this is true to-day a far different story can and doubtless will be told five or ten years hence. It is not so important that two or three lumbermen have been induced to make a start as that all are being educated and prepared for a general movement in this direction in the fullness of time. During the last few years the Bureau of Forestry has received requests from several lumber concerns for plans for cutting their timber so as to insure a future supply. These plans, except as above stated, have not yet been put into operation, because conditions have not been such as to warrant it. But the opening has been made. Lumbermen realize that not only is it possible to carry on their work in this manner but circumstances are so adjusting themselves that it is imperative that it shall so be done.

The lumbermen of the country have keen interest 
in the work which has already been done by the Bureau of Forestry, and in other practical features of its work which have been hardly more than initiated. They appreciate the bureau's investigation of the results of grazing in forest reserves, the prevention and extinguishment of forest fires, etc. They are, and will be, quickly responsive to any practical appeals along forestry lines. They particularly appreciate practical work, as that, for instance, shown by the bureau at the Louisiana Purchase Exposition in determining the relative values and costs of different methods of the preservation of timber and ties; its exhaustive and reliable tests of the strengths of various commercial woods, and especially its eminently practical studies of timber diseases, and the causes of and remedies for blue stain, one of the most prolific sources of trouble to lumbermen during the past thirty years. The bulletin which has been issued upon this subject, entitled "The Blue Diseases of Western Yellow Pine," is therefore of eminently practical interest; and, indeed, all the bulletins of the Bureau of Forestry have reached a higher level of practical usefulness than ever before in its history. Full many a publication bearing the stamp of the Government Printing Office is sent out to gush unread and waste its wisdom on the musty air of attic or cellar, but the additional imprint of the Bureau of Forestry is a most infallible prophecy of a welcome from an interested reader.

Perhaps in this connection better than elsewhere can be illustrated a phase of the change in attitude of lumbermen and those in allied trades toward forestry methods. Twenty years, even a decade ago, lumbermen had a nebulous idea of governmental forestry work. Most of them regarded it with careless tolerance as the labor of impractical experimentalists. The reverse was the condition at the recent world's fair. 
The exhibits in the great Forestry building, and its outlying forest planting area, attracted widespread attention and proved instructive to the lay observer; but the lumbermen and their allies, the great lumber consumers-railroad lumber consumers, manufacturing consumers, and the builders of great structureswhile interested in these things, already more or less familiar to them, found their inspiration and instruction largely in the experimental station in the Mining Gulch conducted by the Bureau of Forestry. Here were congregated every day of the exposition the high officials of the railroad companies, the great lumber consumers, such as the proprietors of agricultural implement works, hardwood consumers seeking substitutes for woods constantly enhancing in price, manufacturers and users of the soft woods searching for enlightenment on methods of preservation and other economic questions. No more complete tribute could have been paid to the work of the bureau and possibly no better illustration can be cited of the change in attitude toward practical forestry:

I would not say to man: "Forbear To use the things God putteth here."

I would not say to man: "Restrain Thy wish for wealth, thy greed for gain." But rather would I say to man: "Use its fruition of a plan; Take then these gifts God giveth theeThe golden fruit, the mighty tree, All pleasant things the fields produceAnd render them to proper use; And, in return, one thing I ask, One simple, easy, proper task: That which from nature you efface With its own seedling life replace." 


\title{
IS FORESTRY PRACTICABLE ON LONG- LEAF PINE LANDS?
}

\author{
BY \\ JOHN L. KAUL \\ President Kaul Lumber Company of Alabama
}

THE subject assigned to me is "The Practicability of Forestry on Longleaf Pine Lands." My acquaintance with the Southern pine belt has extended over a period of seventeen years. During that time I have constantly observed the deplorable effect upon the forest of lumbering without regard to the future. My experience with the actual application of forestry to longleaf pine lands, however, has been limited to the tracts in which I am particularly interested. I have thought, therefore, that the Congress would be more interested to hear of the plans which have been made for the management of the forest on these lands and of the results which have thus far been attained.

I shall deal directly, therefore, with the timber lands of the Kaul Lumber Company, and what forestry offers for them.

These lands are located in central Alabama, and comprise mainly a forest of pure longleaf pine. Situated at a rather unusual elevation for the species, and on the extreme north of its range, the timber is, nevertheless, equal to the best in the more widely known pineries of the Atlantic Coast and nearer the Gulf. The fine quality of the timber and the character of the market which the product reaches has enabled the company to make a specialty of the choice grades of finishing and edge-grain flooring. 
The company has lumbered about 25,000 acres in a county adjoining that in which a portion of its present holdings are located, and where conditions are very similar. These cut-over lands had no general value for agriculture and were without satisfactory market value for other purposes. Their best use is for the growing of timber. A large amount of small timber was left standing on these lands after lumbering, because it did not pay to handle it. As a result, however, of ordinary methods of logging, the timber thus left was not sufficient in amount nor in a conditions to promise another cut of timber within a reasonable period and was an absolute waste. This prompted the company to give serious consideration to the practicability of introducing modifications in the method of lumbering which would insure the leaving, in good condition, of a sufficient basis for another crop of timber. It was at this time that the Kaul Lumber Company availed itself of the offer of the Bureau of Forestry to coöperate with private owners in the conservative management of their timber lands, and a working plan was prepared for the management of the forest in accordance with which the lumbering is now being done.

At the present rate of production, the company will lumber over its holdings in about twenty years' time. The kernel of the problem was, therefore, to so adjust matters that at the end of this period a second crop might be ready for cutting and lumbering might continue without interruption. What the company particularly wanted, then, were the measurements necessary to show with a fair degree of accuracy the rate of growth of the important tree-the longleaf pine-under the conditions obtaining on its cut-over lands, the rate of increase in material, and also in 
money per acre per annum, and the return on the capital invested in the land and that portion of the merchantable timber which it would be necessary to hold over until a second cutting.

Actual measurement of the forest on 5 per cent. of the lands developed the fact that by curtailing the present cut by less than 20 per cent. the company could, after twenty years, again obtain an amount equal to 45 per cent. of the present cut. This at the present value of stumpage, figuring at compound interest, is a 2 per cent. investment, but assuming a rise in stumpage value to $\$ 5$, it is a 6 per cent. investment. Should the value of stumpage reach \$Io per thousand, which we confidently believe will be the case, the value of the timber in twenty years' time will represent an investment of Io per cent: Included in the calculation is a liberal allowance for the value of the land and of the timber held over, and for taxes, and cost of protection.

This assumption of a rise in the value of yellow pine stumpage leads to certain general considerations which influence the practicability of forestry, and brings in a speculative feature of the lumber business in the South. It is only recently that economic conditions have justified the yellow pine lumberman in considering seriously the possibility of holding his cut-over lands to lumber a second time. Up to a comparatively recent date the value of pine stumpage in the South was exceedingly low; means of transportation to market were unsatisfactory; the market itself was restricted and uncertain; and competition with Northern pine was keen. Of late years, however, the development of Southern timberlands has been phenomenal. The growing scarcity of longleaf pine and the steadily increasing demand for it renders 
certain a further rise in its stumpage value. Many lumbermen who acquire stumpage at 50 cents per thousand now credit it in their operations with $\$ 2.50$ to $\$ 3.50$, and believe that in twenty years it will have a value of at least $\$$ Io per thousand. This probable rise in the value of longleaf pine stumpage is the obvious reason for the existence of companies which hold large timber tracts, but do not operate them.

Just here it will be well to emphasize a point which has an important bearing upon the calculations of the financial results of lumbering longleaf pine conservatively. The timber which the Kaul Lumber Company leaves standing after lumbering, consists entirely of small trees below I8 inches in diameter on the stump, the value of which is considerably below the average run of the forest. Every tree contains more or less material which produces lumber of so low a grade that it hardly pays the cost of manufacture, but the smaller trees saw out the grades of low value in far greater proportion than the larger trees.

In connection with the preparation of a detailed plan for the conservative management of the company's timber lands, an extensive investigation was made in our saw mill at Hollins, Ala., to determine the amounts and comparative values of the grades which trees of different sizes will produce. The result of this experiment proved conclusively the relatively low value of the lumber produced from small trees, and was an important factor in influencing the company to lumber conservatively-in other words, it went still farther to establish the bad business policy of putting small trees into the mill, rather than leaving them to reach a more profitable size.

I have found that in forestry, as well as in lumbering, close attention to details is the key to success, and 
often marks the difference between conservative and destructive lumbering. A general lack of appreciation among the woodsmen of the value of the raw material, coupled with an entire disregard of the potential value of immature trees, leads naturally to many forms of excessive waste. Stringent rules and constant supervision are necessary to enforce careful work in the woods.

On our lands we have developed a system of markings for cuttings which is cheap and effective. Instead of marking all to be left standing or all trees to be cut, we mark to be left standing only those trees slightly below the diameter limit; for example, if we are logging to 18 inches, we mark to be left standing trees from $I 2$ to $I 7$ inches which might otherwjse be cut. It is obvious that the marking of smaller trees is not necessary, since they would not be taken in any case. Under this system the markings cost us approximately 3 cents per acre.

Great care is taken in the fellings not to break or otherwise injure the small growing timber. Trees are thrown away from clumps of promising young growth, and slash is not allowed to accumulate around trees which are left standing-a precaution necessary to avoid damage in case of slash fires.

In our railroad construction we avoid as much as possible the use of longleaf pine; not only that which is merchantable at present, but those trees which will become merchantable within the next twenty years. On our main line longleaf pine ties are still used, but they are either sawn at the mill from rough and knotty top logs, or they are hewn from dead and down timber throughout the forest. Ties for the temporary spurs are hewn from valueless hardwoods. For corduroy and cribbing, defective pine is used, and 


\section{AMERICAN ForEST CONGRESS}

this only when hardwood of proper dimensions is not available. The logging engines burn either coal or pine knots, or wood cut from tops; no live timber is cut for fuel. The use of tops, both in logging operations and for fuel, is encouraged, for this not only saves much valuable timber, but cleans up the slash and reduces the danger from fire.

Except where extra length is required to fill special bills, it is a rule to cut short logs in 12 to 16 -foot lengths. This makes it possible to work the trees well up into the tops, and uses the timber much more closely than is commonly done in longleaf pine logging where $\log$ lengths of 25 to 36 feet are out and often a very large amount of merchantable material is left on the ground in tops.

Tapping for turpentine has been a fruitful cause of destruction in forests of longleaf pine. With the greatly. increased demand for naval stores, it has become customary all over the South to box the smallest trees for turpentine. After a few years an abandoned turpentine orchard is a scene of utter ruin. The loss entailed to the productive capacity of the forest is enormous. Improved methods of turpentining are suggested which greatly limit the boxing and chipping of the trees. Small credence will be placed in their effectiveness in avoiding deterioration of the forest, especially by the lumberman who has seen in thousands of cases the loss in lumber value through the after effects of fire and decay which has resulted from the mere notching of trees to test their grain. On our lands turpentining has been limited absolutely to the trees which will be cut for the saw mill, and we turpentine only two years in advance of lumbering. The same mark indicates the trees which are not to be turpentined nor cut for lumber. As long as tapping 
for turpentine is confined to those trees which will within the next two years be cut for sawlogs, damage to the timber is improbable, and the question of the advisability of boxing for turpentine is reduced to one of present profits. Whether the revenue derived from turpentine or from the lease of boxing rights exceeds the loss from the deterioration of the timber before it can be cut is a question which, in my judgment, depends very largely upon the promptness with which logging can be made to follow the orcharding.

In conclusion I want to say a word about the methods of the Bureau of Forestry as I know them on the ground, and regarding, from my own experience, the opportunity which coöperative work with that Bureau offers to lumbermen. The working plan for our lands, which, I am told, you will soon have an opportunity to see in the form of a bulletin of the Bureau of Forestry, has pleased me greatly. It has taken up in a direct and practical way the business considerations which the best management of the forest presents.

I am free to confess that I turned to forestry with some doubts. I was not entirely sure that its policy, admirable in the abstract, concerns itself sufficiently with business considerations to be of real use to the actual operator, but in taking up, on our own ground, the forest problems which confronted us, the Bureau of Forestry has demonstrated, on our tract at leaşt, the eminently practical character of its work.

I have been struck for a long time, and with increasing force, with the fact that the lumber industry deserves recognition in the scientific work of the Government just as much as the work of the farmer and the stockman. We lumberman represent as a whole the fourth greatest industry of the United States, and 


\section{AMERICAN FOREST CONGRESS}

it is upon our use of the forests, the experts tell us, that the national prosperity largely depends. In the Bureau of Forestry, I have found that recognition of the lumber interests which it was my opinion that the Government should offer. I wish, simply because we have profited by the work of this Bureau, to urge upon you your opportunity to take advantage of the same offer of coöperation which has benefited us. 


\title{
IS FORESTRY PRACTICABLE IN THE NORTHWEST?
}

\author{
BY \\ VICTOR H. BECKMAN
}

Editor Paciflc Lumber Trade Journal

THE Committee on Arrangements honored me Practicable in the Northwest?" This is a pretty difficult subject, from the purely commercial standpoint, but one that admits, nevertheless, of much thought and study by the constituency I represent.

Lumbering is the chief industry of the Pacific Northwest, comprising the States of Washington, Oregon, Idaho, and Montana, and the province of British Columbia. In this vast section, bounded on the north by Alaska, on the south by California, on the west by the boundless Pacific Ocean, and on the east by the Rocky Mountains, are upward of 165,000 men employed in the destruction of the "last and best stand of timber," for commercial uses, to whom are paid annually in wages approximately $\$ 75,000,000$, and upon whose labor depends the bread and butter of nearly 400,000 people. The annual output in this territory is about $5,000,000,000$ feet of lumber and 6,000,000,000 shingles.

The amount of accessible timber in the Pacific Northwest is about $400,000,000,000$ feet. Forest fires, owing to lax methods and laws, have destroyed as much timber as has been cut by the lumbermen, and the result of the depletion by man and the elements is apparent in the fact that the best timber contiguous to water and railroad has in many instances been cut 
off, and logging railroads are yearly being introduced for the purpose of going further into the heart of the forest. Much timber is annually destroyed by the ranchers, who burn off large areas for clearing purposes. The time, therefore, is not far off when the logging operations must be transferred to the mountains. Therefore the shrewd lumberman is giving some thought to preserving the existing forests and the propagation of new timber.

Reproduction of trees without assistance is a slow process and not entirely successful. The greatest commercial wood in the Pacific Northwest is Douglas - fir. This occurs in vast bodies and is intermingled with spruce, hemlock, and red cedar. The great belt of spruce lies on the west side of the coast range of mountains, the finest area of red cedar is found in the northwestern portion of the State of Washington, and British Columbia, and apparently ceases after it passes the Columbia River. Hemlock is found with fir, spruce, and cedar, and is more of a general character than the two latter woods. In Eastern Washington, Idaho, and Montana the principal commercial woods are white and yellow pine and tamarack-all reproducing readily. In Southern Oregon sugar pine appears and is a continuation of the belt having its origin in California.

Observation shows that in seven cases out of ten, when Douglas fir is cut, the reproduction is hemlock, an inferior wood, commercially speaking, although superior to the Pennsylvania variety. Where the ground has been burned over by forest fires many years elapse before the soil becomes sufficiently nutritious to reproduce its species. Where hemlock is found intermingled with fir it becomes necessary to cut the former at once, because when left without 
the sheltering shade of the fir it soon dies and decays.

There has been no systematic effort in the direction of tree planting in this section, the aim being rather to preserve the standing timber from forest fires and waste in cutting. Two years ago the writer took up the matter of an effective forest fire law, and the result was the passage of an act by the legislature of the State of Washington making it a penalty to set fires during the closed season, without permits from the county commissioners. The law has worked very well, but it is in need of enforcement, and to this end it is quite probable a State fire warden will be appointed at the coming session of the legislature. Oregon and Montana are also awake to the needs of ample forest fire protection and will probably enact proper laws before long.

The waste in the woods and mills amount annually to about 25 per cent.; or, in other words, about $\mathrm{I}, 000,000,000$ feet per annum is burned in the woods or the refuse burners, because there is no market available for the by-products. This is equivalent to I00,000 dwellings. Distance from market and prohibitive freights are responsible for this waste. For example, the Missouri River territory, composed of Nebraska, Kansas, and South Dakota, consume annually 162,000 car loads of lumber products, of which the Pacific coast contributes 9,I65 car loads annually, and although the difference in the haul from Portland to St. Paul and Omaha is only one mile, it costs \$I5 per I,O0O freight on lumber sold at the mill for $\$ 5$ to ship same to Omaha, as against \$I2 per I,000 feet to St. Paul. Consequently the side lumber is burned.

Forestry is practicable in the Pacific Northwest. The standing timber is its greatest crop-a crop that can be harvested at any time, and is not dependent on 
climatic changes. It should be propagated as well as preserved. Individuals will not do it, and the burden will fall on the State and Federal Government. It occurs to me that if it were possible to enact laws similar to those in force in Germany and Sweden, where the lumberman is compelled to plant a tree for every one cut down, the question of the future supply of timber would take care of itself. In some of the European countries, I am told, the State encourages the planting of trees on waste places by children, at certain times of the year, where each public school scholar plants a tree, and the idea of forest culture and preservation is one of the studies of the public school system. This idea would be worthy of emulation in the United States. Logged off lands should be looked after by a State forester, and should be re-seeded as soon as cut off. In the desert places effort should be made to plant suitable trees with the view not only to timber but other useful purposes. For example, there are large areas of treeless land in Washington, Idaho, Oregon, and Montana, where walnut, cherry and other valuable varieties of trees would grow to perfection. The road commissioners should make it their duty to plant trees along the roadways and a special fund provided for this purpose. This is as important as good roads.

Care should be taken by the State and Federal Government to protect the headwaters of streams. The source of water depends on the preservation of forests. In Spain, the reckless cutting of trees at the headwaters of streams many years ago has converted large sections of fertile lands into arid deserts, and the same is true elsewhere. Trees and vegetation hold moisture and prevent floods and thus create a steady and permanent flow of water to irrigate the parched soil and induce fertility in place of drouth. 
Scientific forestry will create permanent wealth for the Pacific Northwest. It means much to the entire commonwealth because it will not only solve the question of reproduction, but can make the desert bloom, thus adding to the welfare of the people and creating productive land for the new settlers in the semi-arid sections of our country. In this the burden must be shared by all. The railroads should plant trees along their right of way, the lumbermen should replant his logged-off area, the farmer should set aside a portion of his holdings for tree culture, the road commissioners should provide for shade and comfort along the country roads, the State should encourage arbor days and teach the rising generation the value of forestry, and the Government should endeavor to demonstrate in a practical way the necessity for preserving the forests.

There is no question so broad and so worthy of the attention of the people at large as the one of forestry, and it is indeed a good omen when so distinguished a man as our worthy President, Theodore Roosevelt, takes an interest in it. The lumbermen of the Pacific Northwest are his "kind of people." 


\section{INTEREST OF LUMBERMEN IN CON- SERVATIVE FORESTRY}

\section{BY \\ F. E. WEYERHAEUSER}

Weyerhaeuser Lumber Company

PRACTICAL, forestry ought to be of more interest and importance to lumbermen than to any other class of men. Unfortunately, they have not always appreciated this fact. There has been a firmly rooted idea that forestry was purely theoretical and incapable of application in a business way; a prejudice which, in large part through the influence of the Bureau of Forestry, is now beginning to disappear. At present lumbermen are ready to consider seriously any proposition which may be made by those who have the conservative use of the forests at heart.

Lumbermen have been averse also to uniting their interests with those of the government, because of a doubt of the business efficiency of some of the Government's work, and this in spite of the fact, which they recognize, that every possible step should be taken to protect the national land and timber from depredations.

The work of first importance in bringing about the adoption of practical forestry is the work of education. For this, every possible means of reaching the public mind must be employed, and above all the object lesson of practical forestry applied on the ground.

Everywhere throughout our timber regions Nature is struggling to renew her growth, and mere, casual observation forces upon us the fact that the forests will reproduce themselves, if given a fair chance. But 
there are three great obstacles which must be reckoned with in the profitable reproduction of timber, viz.: time, fire and taxes. Let us consider them briefly.

First, as to time. Few lumbermen have watched the growth of timber long enough to know what its increase is. Forestry is a new idea to us, and we have given little thought to the future. Furthermore, forest growth varies greatly in different climates, and in different varieties of trees in the same climate. Before he can consider forestry the lumberman must know the rate of annual growth and the cost of protecting the forests. This information the forester is able to give him. In other words, to tell how long it will take to produce a merchantable tree, and the average per acre. Knowing these facts, it is a comparatively simple matter to determine whether a given forest can be maintained, and yet made to yield satisfactory returns to the owner. Throughout the South particularly, conditions are very favorable and promising. The reports of the Bureau of Forestry lead us to believe confidently that there will be a profit in raising short leaf yellow pine timber, provided that the history of the increase in timber values in the North is repeated in the South, of which there seems to be no doubt. On the Pacific Coast also the climate is suited for the steady and rapid growth of excellent timber. At the present time values there are too low to insure any profit in conservative forestry, but a few years will undoubtedly bring about very different conditions.

The average manufacturer holds too little land to supply his mills indefinitely at the present annual cut. To secure a permanent supply from his present holdings, either they must be increased or his mill capacity must be cut down. Eventually the big mills must clisappear, and in their place we shall have smaller but 
permanent ones. The fact that cut-over lands are covered with young growth, which before many years will be of merchantable size, will add greatly to their value, which will increase more and more as our timber supply diminishes. Moreover, we understand that it is the policy of the Bureau of Forestry not to recommend the adoption of working plans where they cannot be carried out profitably. When business men fully appreciate this fact, it will go far toward securing their coöperation.

The next obstacle, more important because harder to overcome, is fire. I am frank enough to say that in this matter lumbermen themselves are largely responsible, sometimes even to the extent of fighting reform. For example: two years ago a bill was proposed in Minnesota providing for the burning of slashings. Because of the opposition of the lumbermen it was never reported out of the committee. Since then the Government has required the burning of slashings on the Leech Lake Indian Reservation. The wise and moderate regulations suggested by the Bureau of Forestry were introduced with complete success. It was a splendid object lesson. A wisely-drawn bill presented to the Legislature to-day would be supported by the best of lumbermen.

But the lumberman is not only culprit but sufferer also, and he must be protected against loss from fire by the rigid enforcement of proper laws. With a sufficient patrol during dry seasons, and reasonable care on the part of those who start fires, this source of awful destruction can certainly be checked, though it never can be entirely eliminated.

The final obstacle is taxes. If anywhere, it is here that the lumberman practicing forestry under present conditions will be checked, for the lumberman, more 
than any other manufacturer, is the subject of heavy taxation. The local assessor feels that the timber may soon be cut, and that he must "make hay while the sun shines." This policy of drastic taxation results inevitably in the slashing of the timber and the complete destruction of the forest. Here, as before, we meet with the urgent necessity of missionary work in the interest of the forest.

It has been suggested that land held for forestry purposes be taxed with special leniency, or perhaps that the bulk of the tax be transferred from the standing timber to the logs when cut. It certainly is not just that land which can produce but one crop in forty years should be taxed on the same scale as land which produces an annual crop. "Death by taxation" would be the coroner's verdict on many a magnificent forest now laid low. Assuming that the land held for forestry purposes is valuable only for timber, the State would far better collect a low annual tax over a long period of years than levy a heavy tax for a short period; and this is obvious when we consider that an important industry is thus maintained, and a considerable and constant pay-roll secured.

The conclusion we reach with reference to private effort is, that forestry is practical, and can be applied profitably, under favorable conditions; but that only by tremendous effort can the lumberman himself, the legislator and the voter be made to realize its importance and its possibilities. Much has already been done, and we congratulate the Agricultural Department and the Bureau of Forestry on the able and efficient manner in which information is being disseminated. It is safe to predict that their efforts will be followed by actual results.

All arguments in favor of the adoption of conserva- 
tive lumbering by the individual are still more forcible and conclusive when used concerning the adoption of them by the State or the National Government on forest reserves. The question of taxes is at once disposed of, the fire situation is in the hands of those who have ample authority to enforce laws, and the net results in profits can be figured on the lowest possible basis. Furthermore, the State has vital interests far beyond those of the individual-such as the regulation of the water supply in streams, the benefit of forest areas from the standpoint of health and recreation; the perpetual maintenance of a timber supply with its future effect on the price of forest products within the State; the making productive of otherwise useless land, and the maintenance of a valuable industry. For these and for many other reasons far-sighted lumbermen favor the rapid increase of State and $\mathrm{Na}$ tional Forest Reserves, provided they are established only on proper lands.

In conclusion let me say that it was the desire of the Honorable President of this Congress that Mr. F. Weyerhaeuser, of St. Paul, should address the convention. Mr. Weyerhaeuser wishes me to say that he sincerely regrets his inability to be here, and further to assure those present that he and his associates in the lumber business are thoroughly in sympathy with the work and plans of the Association and the Bureau of Forestry, and stand ready to do whatever is in their power to coöperate in them. 


\title{
IMPORTANCE OF FORESTRY TO WOOD- WORKING INDUSTRIES
}

\author{
BY \\ M. C. MOORE
}

Editor of Packages

I COME, before you as a delegate, representing the National Slack Cooperage Manufacturers' Association and the Beer Stock Manufacturers' Association of the United States, both of which organizations represent vast capital invested and an enormous consumption yearly of the best hardwood timber. I am also in close connection with the Tight Barrel Stave Manufacturers' Association, the National Box and Box Shook Manufacturers' Association, the Western Cigar Box Manufacturers' Association, the Eastern Cigar Box Manufacturers' Association, as well as other associations having to do with the manufacture of package material.

Curiously enough, statistics are not in existence showing the immensity of the manufacture of wood in the various lines named. This is a source of great regret to 'me. Only by these figures could I hope to convey to those here in attendance any idea of the great amount of work turned out in all the various lines of wooden package making and the tremendous consumption of timber which is entailed in producing this finished work.

White pine, yellow pine, poplar, basswood, gum, spruce, hemlock, and many other woods in lesser quantity, enter into the manufacture of boxes, and this industry, while not much heard from in a general way, is one of steadily increasing magnitude and importance. 
It has been estimated that the manufacture of wooden boxes alone consumes toward 40 per cent. of the entire lumber production of the United States. When we consider what the aggregate of this lumber production is, and, if we further consider the fact that a wooden box is about the most familiar and frequently seen object on the face of the civilized earth, we can begin to appreciate the figure cut by the wooden box industry alone, in lumber consumption.

The barrel, as we all know, takes no back seat as an industrial container, and it is more important commercially, and is made in greater numbers, with every year that passes, owing to the very rapid multiplication and growth of those industries which are extensive and, in many cases, exclusive, barrel users. The term "barrel," is a very elastic one, ranging from the cheaply constructed article made for truck, salt, and the like, through many stages of increase in value and quality, up to the expensive and substantial packages used for beer, whiskey, oil, meat packing, and numerous other purposes which require the utmost of tightness and quality in a package.

When we stop to think how much flour, apples, sugar, meat, fish, truck, salt, cement, lime, whiskey, beer, oil, molasses, etc., are produced in the United States, and how largely they are dependent upon the barrel as a package, we begin to see what the consumption of timber-hardwood mainly-mounts up for barrel packages alone. The butter tub trade is also an extensive one, and takes a large amount of a very high class of hardwood timber. A great annual production of woodenware in the shape of tubs, pails, firkins, etc., comes in to swell the aggregate in the use of timber by the package making trade. It will thus be seen, without further enumeration of the 
industries concerned, or enlargement upon their vast timber requirements, that the aggregate necessities of the wooden package manufacturers as to timber supply and use are truly enormous.

In thinking of this subject of timber supply for these great trades two questions have been chiefly prominent in my mind. They are wholly practical and, in conjunction with this serious question of forest preservation and supply, they must be adequately met and answered.

In the first place, it is evident that the industries to which I have referred must have timber in large supplies steadily; in even larger supplies than they are using now. Where are these supplies to come from in the future? Will the application of scientific principles of forestry and of reforestation, enable these industries to continue operation indefinitely upon the great scale on which they are operating now, and upon which timber is now being used by them?

Secondly, how will the application of the principles of scientific forestry effect the present manufacturers of lumber of cooperage stock, and, what amounts to the same thing, the manufacturers of wooden packages of all sorts? Should some certain system of forest preservation or reserve be put into obligatory operation, how would it effect the rights of present lumber and cooperage stock manufacturers, and what effect, if any, would it have upon their forest holdings or those which they may in the future acquire?

These, I think, are the most practical points which can be brought up at this meeting, and they are points which must be most carefully considered, from all points of view, before any substantial progress can be made along forestry lines.

I am sorry to say, because I believe that it ought 
not to be so, that American manufacturers of lumber and cooperage stock are, as a rule, looking no farther ahead than the length of their own lives, or their own active business careers, as far as the consumption of timber is concerned. The manufacturer of timber reasons in a truly American way, "Let me get the timber off and convert it into cash. That's my job. I reckon my descendants will be better off with the cash than with the timber, and I'm not looking out for the other fellow's descendants."

This is a natural, and, under conditions prevailing up to the present time in this country, an inevitable process of reasoning, and the result has been the astounding depletion of our forests which has taken place mainly in the last fifty years. How are we going to induce the manufacturer to look at this thing differently, as long as his timber holds out? This, as I see it, is the chief job which we have before us to-day. .

There is, I am pleased to say, one extensive cooperage stock manufacturing concern which is now lumbering a forest extending over about 15,000 acres, on scientific principles, cutting each year only those trees which may be considered to have attained their growth, commercially speaking. The concern alluded to calculates that it will be able to lumber this tract indefinitely, for an untold number of years to come, by the steady application of this principle. It is the fact, however, that few great tracts suitable for the manufacture of cooperage stock now remain to be handled in this way, except in the south and on the Pacific coast. Most manufacturers are working from comparatively small tracts, from which they feel obliged to cut all the timber they can use, whether the same has or has not attained full growth.

There is one fact which seems to me generally en- 
couraging to the principles of forestry as set forth at this convention. This is that many hardwood tracts which have been cut over by manufacturers a few years since, all timber of suitable size having then been cut away, have now, in the space of five or ten years in many cases, attained trees of sufficient size so that mills are again going into these sections, although they had been deserted, as exhausted, by other mills comparatively a few years ago.

The industries which I represent must have timber. They must have a very great amount of it. They must have it steadily available on a strictly commercial basis. Now what can the principles of scientific forestry do for these industries in a practical, businesslike way which will place no hardship upon the manufacturers, but which will still preserve the timber indefinitely for their use? All are greatly interested in this question and are looking to this Congress to furnish at least some advance toward a solution of it. What is the solution? 


\title{
IS FORESTRY PRACTICABLE IN THE NORTHEAST?
}

\author{
BY \\ JOHN A. DIX
}

President Moose Riyer Lumber Company, of New York

THE first Americans were not skilled in the art of husbandry; they considered the forest only as the means of providing food and raiment, and in their minds the value of the trees was measured by the protection to wild animals which provided food or the skins of which entered into the economy and necessities of existence. An occasional and convenient piece of wood gave warmth or served as a means of preparing food.

It is fair to presume that the advent of the Pilgrim Fathers and by them the immediate removal of the forests to enable them to till the soil and reap the results donated by years of timber growth, caused the natives to look upon the new order of things with disapproval. The forests readily yielded to the axe of the pioneer; trees only impeded the progress and advance of settlements. A small percentage of the timber was converted into structures for homes and into stockades for protection, but the greater portion of the forests yielded to fire and was consumed as waste. From this beginning the consumption of the forests has been unremitting without consideration of a future supply. We hear occasionally that timber is getting "farther back" and more expensive, but as soon as the demand is keen the means of penetrating to the supply do not deter the lumbermen from obtaining the trees.

Only recently the saw mills have deemed it import- 
ant to utilize thin saws instead of converting an unwarrantable amount of good material into saw-dust.

This tendency to economize in the manufacture of lumber is the suggestion that the end is in sight. Thoughtful people who are interested in forest lands, as well as those who derive an income from the products of the forests, are giving timely heed to advice and information now being given by the Bureau of Forestry as to the importance of reforesting lands which have contributed to the demands of civilization.

Wise assistance given to the meagre natural conditions of reproduction will yield profitable results, and the lumbermen are not alone in their anxiety about future supply. Railroads and telegraph companies are considering and experimenting with methods of preserving timber which enters into their needs. If an economical wood preservative will add 50 per cent. to the efficiency of timber, the demands on the forest will be correspondingly decreased, and those who use, as well as those who provide, are much interested in the progress of this feature in the Bureau of Forestry. France, Germany and England have practiced this economy and demonstrated the practicability of treating wood for railroad ties and telegraph poles, but their lesson has been one of necessity, not of foresight. We do not anticipate and practice these economies because timber has been abundant. We are, however, passing through a period of transition and the admirable work of the Bureau of Forestry in coöperating with the different States to achieve results which will mark a new epoch in forestry will be to the lasting benefit of future generations.

Along with the accomplishment of reforesting, we should not be unmindful of the tremendous waste and permanent destruction of the soil resulting from forest 
fires. Concerted action must be insured for the careful watching and successful preventing of fires in the forests. The successful method to accomplish this important work would be to employ at commensurate wages a competent and skillful fire warden to preside over a certain district and to employ under his direction the students from the several colleges of forestry. This experience for the students would be for a short period of time each year during the season of drought prior to the time when the shrubs and trees are budding. Military colleges require students to devote a certain amount of time to become experienced in the art of drilling. Is it not quite as important that the colleges of forestry require practical experience?

New York State has been active for a few years in planting seedlings of spruce, pine and hardwood on denuded lands. The work has been intelligently prosecuted by Col. William F. Fox, who is an ardent advocate of the importance and common sense practicability of this nethod of reproducing timber; of securing to the soil the properties Nature intended should exist. If proper encouragement is forthcoming, the systematic annual planting of seedlings will be carried out in the State parks, especially in the Adirondacks and the Catskills. There are important successful nurseries established for this purpose and the advocates of this method of reforesting believe and teach that the increased value of these denuded lands will be far in excess of the actual expense of planting. The beneficial results which will follow by the retention of moisture, by the improvement of the soil and the contribution to the economy of commerce and navigation, all these are in line with American progress. It is a well known fact that each tree thus planted will contribute its share to the humus which 
is the natural sponge or source of every mountain stream. If this source is protected or created we are at the very foundation of economy, assisting to create a condition of preventing torrents.

Private owners of timberland should be encouraged to plant annually as compensation for the removal of trees, for the reseeding of burned lands, and thus make a beginning to restore the natural conditions of the soil. It has required years of education to have this feature of forestry become attractive to the lumbermen, yet to-day it is with pride that New York State can announce to this Congress that denuded tracts are being planted. One lumber firm has successfully planted pine seed on a tract which had been burned, and the method employed was to sow the seed in rows of six feet and six feet apart, thus leaving a space between the rows which will be planted with seedlings as soon as they have attained sufficient growth, This same firm has established a nursery and is giving special care to the growing of spruce and pine seedlings for planting on its own preserve.

The system of timber cutting or lumbering is of tremendous importance bearing upon the future growth, especially for spruce trees which no doubt are the most valuable products of the Adirondack forest to-day. The natural tendency of the spruce tree is to rest unless the proper amount of light is admitted to its immediate surroundings. The plan, therefore, of timber cutting is to remove mature trees, using judgment to cause as little destruction as possible to the small trees. The use of defective hardwood trees for the building of roads and bridges and for the use as skids will benefit the conditions of growth for the remaining spruce trees.

The importance of leaving on high ground an occa- 
sional mature tree for seed purposes cannot be too strongly urged. This will continue Nature's method of reproduction and not destroy all of the possibilities of future growth. The small trees will take on new life and reveal a marvellous increase of diameter if their condition is benefited by the removal of defective hardwood, and as an evidence of this future growth, data have been tabulated which reveal the following careful estimate. Virgin forests of spruce, if cut to a twelve-inch basis; that is, all of the twelve-inch trees left standing, an equal product can be harvested from this same territory in a period of twenty years. Should the land be cut to a ten-inch basis, it will require forty years to reproduce, and should the cutting be made to an eight-inch basis, a century of growth will be required for a yield equal to the original cutting or harvest.

As an evidence of the resting qualities of spruce, a small tree of fifteen feet in height growing underneath a cover of large trees, was cut down and examined as to its annual rings. It revealed a growth of about one century, yet this tree, had the cover been removed, would have taken on new life, grown as rapidly as a vigorous young trees of a dozen years and been a competitor for an equally good yield of timber.

Our population is not great enough to enable us to sweep and garnish our forests as practiced in some countries where the natives are glad to get the waste or fallen branches for fuel. On the Island of Madeira, fuel is annually grown from seeding the mountainous lands with pine seed. As soon as the trees have attained fifteen feet in height, they are carefully removed, roots and all, bundled and sold in the city of Funchal as the principal product for fuel. This process has been in existence for years and evidently is on a paying 
basis. One can see the stages of growth from a few inches in height to the tree of sufficient size for market. We may be compelled to take a lesson from our Portuguese friends if we continue to demand from the forests without contributing to future growth.

Lumbermen, as a rule, do not spend time with theories which are not practical. The winning of bread by cutting wood is an old-time vocation, and the one is quite as difficult as the other; the application of energy or brawn will obtain an equivalent to purchase bread, and no thought is expended on a possible plan to make two trees grow where there was but one. Yet our minds are turning to the reproduction of that opportunity of winning bread, and this Congress is an evidence of that trend of thought.

Recently the beneficial results of having waste lands adjacent to cities covered with a growth of fir trees, have been discussed by professional men who believe that dusty cities can be improved from a sanitary point of view by having the outlying districts covered with pine trees. They realize that the trees will hold the sandy soil, bring back its fertility and give to the atmosphere the properties of the woods. Invalids seek the woods; why not bring the forests to the cities and benefit those people who cannot go thither?

Bulletins issued by the Bureau of Forestry under the wise, intelligent, and practical direction of $\mathrm{Mr}$. Gifford Pinchot, have created a desire to demonstrate on the part of progressive lumbermen, that the fact of reforesting lands is important. This Congress will broaden the sphere of practical forestry. It is the nucleus of a movement that will take root in the soil of every State, and, like the proverbial mustard seed, spring up and wax into a great tree. 


\section{OUR PACIFIC COAST FORESTS AND LOGGING AS DIFFERING FROM OTHER FORESTS}

\section{BY \\ COLONEL GEORGE H. EMERSON}

Vice-President The Northwestern Lumber Company, of Washington

THE summit of the Cascade Mountains is the line of division between the timber of eastern and western Washington, also of eastern and western Oregon. To the east lie open pine forests, similar to those of the Southern and Eastern States. To the west is a dense jungle of giant trees.

On the gravelly land of the western slope of the Cascades the timber is of moderate size and consists almost entirely of Douglas fir and red cedar, with moderate underbrush. The fir is from 24 to 40 inches in diameter, and from 100 to 150 feet tall and the cedars are of about the same diameter, but less height.

On the lower bench and bottom lands, east of Puget Sound, and on the clay lands wherever found, fir, cedar, and hemlock intermingle, and near the coast spruce is abundant, sometimes growing alone, but more often. with the fir and other woods. On these lands our large timber grows, fir and spruce from 40 to 80 inches in diameter and from $I 50$ to 250 feet in height. These dimensions are common, and Io feet for fir or spruce, and 20 feet for cedars, are not extreme diameters. The hemlock is of less size; 18 to 24 on the stump is most common, 40 inches not exceptional.

Beneath these trees often lie the fathers of the forest, still sound, pinned to the ground by the roots 
of trees themselves a hundred years old, and over and among all is a growth of salmon-berry, salal-berry, and other shrubs and tall ferns, making an almost impenetrable mass, so dense two miles is a good day's travel, on courses, for a woodsman.

These tracts, where the timber is large, have few young trees, and the old giants are over-ripe. It is doubtful if they produce seed, and doubtful if their growth equals their decay on many townships. They cannot be thinned, all must be cut; any left, as are the hemlock, and until recently the cedar, are broken by the falling of their neighbors, or blown down when their neighbors are gone.

The mountain sides have deep canyons and the foothills are steep, and jointly they are most of the timber area of western Washington and Oregon. Methods of forestry adapted to eastern timber areas are useless here, as are eastern methods of logging.

The first efforts to handle this timber were those of building "skid-roads" up the gulches, cutting the timber into eastern lengths, I2 to 24 feet, and then with six yoke of oxen the logs were hauled, one at a time, to the water. In those days there was no demand for cedar or hemlock, and both were left in the woods. Neither offered the per cent. of clear the fir and spruce offered, therefore why waste time on the low grades? The supply looked inexhaustible; standing timber had little value; butt cuts of the hemlock sometimes sunk; customers wanted only fir and spruce; redwood furnished shingles; why then use low grades or hemlock?

On these old choppings all hemlock, cedar, lowgrade fir and low-grade spruce trees, all broken cuts, all butts with center decay, all trees with "conchs"indicating rot-all stubs, or dead trees, with loose bark, 
all tops, from the clear trunk up, 50 to I 50 feet in length, 20 to 60 inches in diameter, all these were left in the woods.

As if fearful of taking too much of the forest to the mill the timber fallers vied with each other to place their chopping boards higher, and many a stump, I6 to 20 feet in height, marks the success of their efforts.

The aggregate of this waste reached over 60 per cent. of the forest and left the ground covered with tops, broken timber, and brush, many feet in thickness. To this, when dry, fire was set. The fire killed all timber left standing, burned any young trees and the hemlock seeded the ground. Later, the dead hemlock fell, and a few years after the first fire, a second, or even a third, went over the ground and the hemlocks were no more. Only tops and trunks and a desolate waste was left. Then the ferns and blackberry vines, as if to hide the shame, spread over all their mantle of verdure.

In this way, and by fire in green timber, townships of lands, valuable only for the timber crop, have become worthless wastes. Where young forests should be growing to keep good our timber acreas, charred trunks are piled on trunks, under a tangle of vines.

Times have changed somewhat. Steam skidders for yarding, and steam road engines for hauling, have replaced the bull team. The railroad is fast replacing the river.

Cedar has become the most valuable of our woods, and hemlock is found to be our most beautiful interior finish. Standing timber has a greater value and is cut closer, but enormous tops and most of the hemlock are still left in the woods. Logs with no clear cannot be handled at present prices of lumber without loss. The per cent. of the crop now saved is increased, but 
40 per cent. is still wasted, nor is it the worst. These choppings, with their continuous piles of tinder, are ready to flash into flame from the spark of a match, and when conditions are right they burn with a heat so intense it reaches to adjoining green trees, and they, burning like torches, create a whirlwind that, with the roar of an avalanche, twists the tops from the trunks.

As before stated, the application of any method of forest perpetuation adapted to eastern woods is impossible, yet most of the country where these forests grow, is valuable only for a timber crop, and could it be reseeded with fir and spruce when cut, and fire kept out, at the end of fifty years there could be harvested a second crop of 50,000 to 100,000 feet per acre. The things necessary to accomplish that end appear at present almost impossible. They are:

First, that all timber growing on the land be cut.

Second, that all timber be removed.

Third, that all left be burned.

Fourth, that the seed, of the timber wanted, be sowed in the ashes.

After this is done, the danger of fire is so small it need not be considered.

Our seasons are sometimes divided, by strangers, into two, the wet season and the month of August. Vegetation, therefore, is of very rapid growth, and before another August, the ground would be too well covered to become dry, therefore no fires would run.

To teach the people to utilize the product of our forest, so as to clear the land of all things of value, is one of the great duties of those who are anxious to see our forests perpetuated. The fir tops of our woods are sound, and sound knotted, and more durable for mining timber and railway ties than are the hearts 
of our logs, now furnished for these purposes, but they are worth in railroad ties, at this writing, less than $\$ 6.00$ per thousand feet of manufactured lumber, while the cost of hauling and sawing exceeds that figure. Then, too, while hauling one of these tops, a surface clear log could be hauled, worth $\$ 6.50$ or $\$ 7.00$ per thousand feet, against $\$ 3.50$ per thousand for the top in question. Again, while sawing this top into $\$ 6.00$ lumber the mill could have sawed a $\$ 7.00 \mathrm{log}$ into lumber, of which 40 per cent. would be clear, 40 per cent. good building grades, and only 20 per cent. \$6.00 lumber. Sawing the top the "saw" bill would be $\$ 2.50$; on the good log perhaps $\$ 5.00$ or $\$ 6.00$ per thousand feet, and the same is true of the hemlock, yet the hemlock is the best of box material, and the small per cent. of clear, different entirely from eastern woods of the same name, is a beautiful interior finish.

Were we a little nearer the great markets of the United States, or were our freight rates less, or were the demand a little larger, these tops and hemlock could be handled, and the greatest difficulty in perpetuating our forests thus removed.

The bark of this hemlock is superior in tanning qualities; tanning extract plants would help solve the problem; pulp mills could use to advantage our hemlock and waste spruce; fir tops, stumps, and roots are well supplied with pitch, and experiments indicate the values obtained from those sources in turpentine, tar, pitch, rosin, wood alcohol, creosote, lamp black and charcoal, and other chemicals, are greater than the balance of the tree affords in lumber. Short lengths of our cedar make shingles; short lengths of our spruce make staves; short lengths of our fir make porch flooring and car siding; fir bark and limbs 
should have a value; when our tímber is utilized as our cattle and hogs are utilized, and every part saved, the other things required to perpetuate our western Washington forest will follow as good investments.

To the perfecting and teaching of these methods, therefore, we should turn the attention of our Government, our chemists, and those who desire the perpetuation of our forests. By such methods our lands would be placed in the best condition for future timber crops, and those crops could be fir, spruce, cedar, black walnut, ash, or maple, and any of these would be ready to harvest before our present timber is exhausted.

Tardy forest reserves make possible wise provisions for the disposition and perpetuation of the small remnant of our timber still in the hands of the Government, but laws for the use and perpetuation of this timber must vary with location. No rule of selection can be applied to western Washington or western Oregon; no rule of clean cutting and reseeding can be applied to eastern Washington or eastern Oregon. Western Washington and western Oregon rainwall and water supply are excessive, and need not be considered; eastern Washington and eastern Oregon need first consideration be given to these questions; a general law, to apply to the cutting and perpetuating of the timber on all Government reserves, would prove as wrong as have our laws in their application to these areas.

To these pathless jungles, where no man could live except upon provisions packed upon his back, where to make a clearing of an acre costs labor worth $\$ 200$ and destroys timber worth $\$ 50$ more; where the sun sends but pencils of light, and the fallen timber, of centuries back, is as sound as if always submerged; where the surface is made up of gulches, canyons, and 


\section{AMERICAN FOREST CONGRESS}

mountain sides; where agriculture is impossible, and the only value is timber, our Government extended its Homestead and Pre-emption laws, framed for our prairies. To acquire title one was supposed to settle on the land, make it his home, make a clearing, plant a crop, build a house, and maintain a residence.

To acquire title, therefore, he must waste time which should go to the increasing of our national wealth, must destroy a portion of the timber, to which he is striving to obtain title, and thus destroy national wealth, must deprive his family of his support, must live in danger of falling trees, of accidents, with no one near, or he must perjure himself, and little wonder he did the latter, when by doing so he only chose between evils, and chose the one of least real harm. Not quite perjured himself, for he could cut some brush, set out a few fruit trees in the forest and a few cabbages, visit the "claim" every six months, pack in a half window for his "shake shack," leave an axe and a fry-pan there, and thus ease his conscience and those of his witnesses when the day of final proof arrived.

In this proof he had to swear the land was "chiefly valuable for agricultural purposes," but the decision of the General Land Office eased his conscience by declaring all land "not stony or gravelly was argricultural," yet during his lifetime he never expected to see anything grown on this land but timber. Public opinion approved such an evasion of a ridiculous law, and our Government, not the settlers, should be investigated when complaint has been made, by a less fortunate, and the clearing has been hard to find and the house does not look as if ever used for a home.

Our timber act was more just, but framed in the interest of land grabbers. These stood ready to loan 
money needed to pay for the land, perhaps without exacting a promise, so the claimant could swear "he took the land for his own exclusive use and profit" and "had not promised to mortgage or deed." Later he could change his mind.

Still more ridiculous and criminally wrong was the lieu land law, by which anyone claiming within a forest reserve, relinquished to the Government, and selected equal areas outside the reserve.

Floating on Puget Sound upon a summer's day, when gentle zephyrs fill the sail of the boat, one's languid gaze wanders back over vast areas of dense, dark green woodlands, on up the slopes of the mountains, until arrested by the towering snow-cap of Rainier, I4,000 feet above; to the south, not seen, stand St. Helen, Adams, Hood, and Jefferson, of nearly equal height, and to the west glisten the Olympic range with long reaches of snow-capped peaks. Part of these peaks are in the Rainier, part in the Olympic and part in the Cascade reserve, and part are also within railroad grants, and for these glaciers and rocks our Government has exchanged some of her best timbered townships. Along the lower side of some of these mountains, loggers have been busy with axe and fire, and for their denuded, fire-swept lands, our Government has given fresh timbered areas. Many men who have secured a quarter section, under the Homestead or Pre-emption or Timber Act, have been investigated for fraud. These larger selections are authorized by Act of Congress and have not been questioned.

In the home of the fir, the spruce, and the cedar, the song of the axe, the saw, and the hammer begins with the dawn and rests only with the close of the day. Go where you will the crop of the centuries is being 
harvested. With each breath a monarch of the forest falls; engines whistle to engines, as the huge trunks of these noble trees are dragged to the water or to the railroad; the locomotive whistles to the mill, as it comes with long trains of wealth of our forests, and the mill whistles back to the locomotive, as its saws sing while they work; steamers for coastwise and trains for eastern markets whistle back to the mill, as they hasten with its product; the deep loaded ship spreads its sail and the winds waft our lumber to the far corners of the earth; in all ways the harvest goes merrily on, and the song of the axe, the saw, and the hammer, are sweet to the ears of our people, for they sing of industry, prosperity, and happy homes.

But is there no other note in the song? Do these people ever think of the centuries their crop has been growing? Does it never occur to them they are the trustees of an heritage for future generations, to be guarded, cared for and watched, used from sparingly as necessity requires, or price justifies, but not to be wantonly wasted or destroyed, or disposed of without adequate returns? And how are they fulfilling their trust?

They are leaving nearly half of the crop in the woods to be burned, and burning, destroy more, and for the half they are marketing they are obtaining no proper equivalent. They are leaving the ground a fire-swept, desolate waste, where fire will follow fire, until all things valuable have been destroyed. They are taking to themselves the whole of the heritage entrusted to them, and in return are not even scattering a few seeds for the benefit of their children. They are vandals, but no law can reach them. They would be adjudged insane, except for the necessity which governs. The sacred right of property is theirs, and they can do as they will with their own. 
They can only be reached, and these grave errors corrected, by making other methods to their pecuniary interest; teach them, therefore, the value of their timber; show them ways of turning their waste to profit; send to them pulp mills, chemical works and tanning extract plants; help them to show the transcontinental railroads the short-sighted policy they are pursuing; build for them a double track road and give to them lower freight rates and from that, now wasted, they will furnish ties for the North, boxes for the Middle West, cheaper lumber for your homes, perpetuate their forests, operate their mills through the centuries, and the song of the axe, the saw, and the hammer will have no note of discord and continue in the land of the fir, the spruce, and the cedar. 


\title{
THE ADVANCE IN THE VALUE OF STUMPAGE
}

\author{
BY \\ JAMES T. BARBER
}

President Northwestern Lumber Company, Wisconsin

$\mathrm{THE}$ selection of the writer to furnish for your conconfines the question to the value of white pine stumpage in Wisconsin, as his experience and observation have been confined to this quality of timber and to this locality. Every one, at all familiar with timber values, knows that the advance in white pine stumpage in this State in the past thirty years, has been phenomenal, but few realize its full extent. This advance has been peculiar when compared to other property, in that, while the increase in values has not been regular and continual, the market price of pine stumpage has never taken a step backward. Every change' in prices, from year to year, has been upward.

Perhaps as good an illustration of the increase in values of this class of property, covering practically the entire period of development of extensive lumbering operations in Wisconsin, is the experience of Cornell University. In 1862 the Congress of the United States apportioned over $9,000,000$ acres of land to the different States, the proceeds of which were to be devoted, by the several States, to the establishing and maintenance of schools and colleges in which such branches of learning as are related to agriculture should be taught. Scrip, called Agricultural College Scrip, was issued to the several States and by them placed upon 
the market. In 1865 this scrip sold at fifty cents per acre, and in 1866 Honorable Ezra Cornell, who had previously founded and endowed Cornell University, at Ithaca, New York, bought something over 500,000 acres of this scrip from the State of New York, paying therefore 60 cents an acres for the account of the University. At this time the college was not in a financial condition to purchase and locate this large amount of property, and $\mathrm{Mr}$. Cornell assumed to pay for the scrip and also the expense of locating it on pine lands in Wisconsin. This action was taken, and so well was the work done that the scrip cost of the pine stumpage was from six to ten cents per thousand feet.

In I874, shortly before Mr. Cornell died, he turned over the property to the University, and at that time the cost, including all expenses, was over $\$ 500,000$, or possibly fifteen cents per thousand feet. Shortly after the University took charge, a systematic effort was made to dispose of the timber, and at the close of I882, the aggregate sales amounted to $\$ 3,700,000$, this including the first large sale of 100,000 acres at $\$ 4$ per acre, or, say, thirty to forty cents per thousand feet, made in 1873. At this time the cost of the property, including taxes and all other expenses, had risen to $\$ 2,200,000$.

The University has now practically closed out its timber holdings in Wisconsin, and the net result of the purchase of the 500,000 acres by Mr. Cornell, in I866, at sixty cents per acre, after deducting cost of the scrip and locating the same, taxes, and all other expenses, was within a very few dollars of $\$ 5,500,000$. The University property was wonderfully well handled, the top of the market being obtained in almost every sale. It has only been within the last few years that 
any other value than that of pine stumpage was placed upon their lands. Some of the more recent sales of pine have been on the basis of ten and twelve dollars per thousand and on estimates including much timber which would not have been considered at all ten years ago.

Representatives from the South can easily remember the twenty and thirty cent period, although it soon recedes into ancient history as they count their present three and four dollar values, and even our friends from the Coast, as they watch those beautiful fir trees go into logs and \$1.00 and \$1.50 stumpage, can smile as they recall the purchase at ten and fifteen cents.

Is it too much to ask you to believe that the history of Wisconsin will repeat itself in the South and West, and that the timbers owners of those regions may watch the continual advance of values until at least the ten dollar and twelve dollar epoch arrives? 


\title{
IMPORTANCE OF LUMBER STATISTICS
}

\author{
BY \\ GEORGE K. SMITH \\ Secretary National Lumber Manufacturers Association
}

I $\mathrm{N}$ the lumber industry, as in all others, the constantly recurring questions to be answered daily, monthly and annually, are "How much?" and "How many?" In order that the manager of a manufacturing plant may have the means of answering these questions, daily reports from each department are made, weekly statements are prepared, monthly summaries are compiled, and annual reports are evolved. Such collections of figures as these are known by the general term of "statistics." The original use of the word was confined to the enumeration of persons, but custom has made it apply to any systematic collection of figures.

In a most valuable and comprehensive paper entitled "Stumpage," read by R. A. Long, of Kansas City, at the thirteenth annual meeting of the Southern Lumber Manufacturers' Association, New Orleans, January, I903, this sentence was used, "Knowledge is an asset, the result of which is profit." For the purpose of this discussion, let us paraphrase this sentence and say, "Statistics are an asset, the result of which is profit, and the lack of them a liability, the result of which is loss."

In order that we may learn how this asset is acquired, let us ask the manager of a large plant, how much it costs to produce $I, 000$ feet of lumber, the unit of all 
lumber transaction, and follow him as he refers to various reports to prepare the answer.

First, the actual or arbitrary price of stumpage; then the log cutters, log haulers, the scalers, loading crew, and $\log$ train reports combined, give the figures of the raw material in the pond; the scale sheets on the logdeck, or the tally sheet at the tail of the mill, gives the daily output; then comes yard and dry-kilns, planing mill and loading dock, and the shipping ticket is ready for the invoice clerk.

With additions to cover the proper portions for superintendence, insurance, interest, taxes, and depreciation, the manager has a dozen or fifteen items whose sum is the desired answer. He has done so well in promptly supplying the desired information that we follow with another "how much?" This time it is: "How much lumber do you make each month?"

The saw-mill reports are consulted, and if steady time has been made, twenty-five or twenty-six items are added, and the result announced. Then comes the total cut and shipments for the year, with total cost, and gross and net receipts, and the systematic collection of figures called "statistics" is ready for the annual meeting, to be discussed and digested by the directors.

These figures are of the utmost importance to the stockholders for they reflect in concrete form the profit or loss for the year. Every effort is made to have them correct, and they are carefully preserved to be compared with the next series, month by month.

In the operation of a single plant statistics can be easily obtained, because the manager has power to control all departments in his own immediate circle. In speaking of the "circle" of the single operation, a diagram is suggested which represents the lumber producing field in its entirety. This diagram consists 
of three circles; the first containing the single saw mill; a larger circle including hundreds of small onesthe mills producing one kind of lumber; and the third, one which includes both the others, and its area embraces all the other lumber mills in the United States.

In studying the annual report, one of the directors notices that the amount of lumber on hand is much larger than in former years, and because the profits are still in lumber and not in cash, he asks the reason for the increase. To answer this, and if possible justify the condition, the manager must get figures outside the circle of his plant, and show how much other mills have.

Foreseeing such a question, and realizing that it would be difficult for each mill to gather information systematically from all the other mills cutting a similar kind of lumber, the manager has already called his neighbors together and formed an association to gather statistics regarding stocks on hand. By consulting the figures furnished him from the headquarters of this association, he finds the mills in the "second" circle have more lumber than a year ago, and a summary of their stocks on hand shows a total increase of $200,000,000$ feet. The sales agent for the company is present, and is asked what effect this increase of stock on hand will have on values. He has not only studied the situation in the second circle, but has looked beyond into the third circle, and has discovered that the statistics of competitive woods, so far as he can learn, show a similar situation existing, and reports values in general, weak and declining.

When the information resulting from statistics is revealed to the directors, its importance and value is recognized, a basis for intelligent action is secured, and instead of increasing their output, as originally 
planned, they arrange to produce even less than their average, until their visible supply is reduced to normal proportions.

After deciding on a course of action for the coming year, they fall into general conversation for a few minutes, when a new line of thought is opened by the questions "How many acres of timber did we cut this year?" and "How much timber have we standing?" Here is need of more statistics and the manager consults maps and records, and soon reports the exact conditions. As the amount is large, some one asks how much timber is there in the State, and what per cent. of it do they own? They call for statistics on this particular feature, but as the manager has not promoted an association for this purpose, he cannot answer. One of the directors has anticipated such a question, and produces Volume IX of the twelfth census, containing special reports on selected industries, lumber and timber, covering pages 805 to 897 . In this he finds, on page 840, the estimated total amount of timber in the State, and the percentage of their holdings is determined.

Having discussed the operation in the first circle, and noted the answers given, and the stock conditions at the mills in the second, we naturally advance into the third circle and put the question "How much?" as applied to the entire industry.

Before answering this, let us notice how the elaborate statements of the individual operation, in the first circle, are condensed for use in the second circle. All of the figures and reports used in producing the first exhibit of total cut, total shipments, and stock on hand, are discarded, and these three items from every plant in the second circle, form the basis of the answer we are now seeking. 
Large figures are needed to describe the lumber manufacturing plants, the amount produced annually, and the amount of standing timber. Thirty-three thousand and thirty-five establishments were in operation in 1900, and produced $35,084,160,000$ feet, board measure, in that year.

Ten kinds of timber, counting all hardwoods as one, show a total of $1,240,000,000,000$ feet available for lumbering. These figures are interesting and important, but nowhere do we find the amount of lumber consumed annually, and the amount on hand at the beginning of each year; or, in other words, what proportion of the thirty-five billions was used during the calendar year, and what per cent. remained on hand.

Attempts are made by the twelve lumber manufacturers' associations composing the "National Lumber Manufacturers' Association," to procure these figures, but of the thirty-five billions shown to be produced, less than one-half is accounted for by these twelve associations. The need for, and the importance of exact information as to the total amount of lumber in the hands of the manufacturers at the beginning of each year will eventually draw all lumber producers together, and instead of depending almost entirely on a census report published once in five years, they will have figures of their own annually, on which to base their calculations.

Already steps have been taken to secure the names of 33,000 manufacturers of lumber, and obtain annual reports from them, covering the three essential points, viz., the amount produced, the amount sent forward to the consumer, and the amount of stock on hand when annual inventories are taken.

The importance and value of such statistics can be 
illustrated by relating the experience of manufacturers of one kind of lumber, who for several years have made a systematic collection of figures. During a period of nine months stocks among 200 mills increased I 50,000,000 feet.

These figures were obtained in two ways-by a record of the excess of cut over shipments, showing a steady increase each month, and a semi-annual inventory compared with the inventory of January Ist. These statistics revealed a serious situation, and were the cause of an early meeting, at which it was decided that less lumber should be produced until the visible supply was reduced to normal amount.

The argument is used by some that such conditions, as were revealed by the figures just quoted, should be allowed to correct themselves-let the disease run its course-but in these days of growing scarcity of stumpage, with only one crop in sight, the majority believe that reliable statistics, showing a heavy accumulation of stock, should serve as a danger flag, and the speed of production be reduced until the rough part of the road has been passed.

To continue production up to full capacity, when undisputed evidence is produced that a large surplus already exists, is unwise and unprofitable, and an unnecessary sacrifice of stumpage, which on account of our steady increase in population and consuming territory, is becoming more valuable every year.

The importance attached to statistics in other commodities is well illustrated by the annual report of the statistician for the Department of Agriculture, for the fiscal year 1903-1904, published in the December issue of the Crop Reporter. The fact that our Government has made the Census Bureau continuous in its organization, and reduced the period of census returns from 
one in ten to one in five years, is another evidence of the importance of up-to-date statistics.

The steady growth of all lumber associations, having for their object systematic gathering and compiling of figures in the three circles, is the best proof of the importance of statistics, and when all manufacturers realize their bearing on the individual operation, and on the group of mills, and on the combined whole, some broad association now organized, or yet to be born, covering the entire industry, will be able to give what every producer is waiting for, correct statistics relative to production, consumption, and visible supply, which are the three factors governing values.

These facts are of sufficient importance to warrant united and persistent effort to secure them.

Such gatherings as this Congress, tend to hasten the day when the manufacturers of lumber, and owners of stumpage, will work closer together, and determine annually how rapidly our forest resources are diminishing, and thus realize more and more the "Importance of Statistics in the Lumber Industry." 


\section{OPPORTUNITIES FOR LUMBERING IN THE PHILIPPINE ISLANDS}

\section{BY \\ CAPTAIN GEORGE P. AHERN}

Chief Philippine Bureau of Forestry

I $\mathrm{N}$ I876 the Spanish officials estimated the forest area of the Philippines at 5I,537,243 acres. In I89o Fernando Castro estimated it at 48, I 12,920 acres.

The forests of these islands are unlike those usually found in temperate climes, in that no one species, except the genus pinus, is found in pure different stands. A stand containing forty species or more to the acre is not uncommon. Such forests are naturally cut by the so-called "selection" system. The trees removed in selection cuttings are those from 24 to 40 inches, thus leaving in the forest only young trees too small to cut, and over-mature trees, which are generally defective and which should have been the first ones removed, as the timber of the same becomes less valuable each year. The seeds of these old treesthe source of reproduction-generally do not reproduce as vigorous seedlings as do seeds from trees in the prime of life.

Under the native methods of lumbering, after the felling of the medium-sized trees of desirable classes, we generally find left on each acre a great number of trees which have very little present merchantable value. These present a serious difficulty in that these trees frequently bear a greater amount of seed, and at an earlier age than do trees of the better species. In marking and selecting trees for felling, the forester attempts 
to avoid the above bad defects of cutting by insisting upon the removal of as much of the poorer grades as possible, and attempts to aid the reproduction of better species in every possible way.

No complete survey of standing timber in the islands has ever been made. No record can be found of any such work having been attempted during the Spanish administration. Since the organization of the present Bureau, this work has been commenced in six provinces, in virgin forests as well as in regions that have been severely cut. At the same time, vigorous work is being done towards acquiring a knowledge of the forests everywhere in the islands. A large herbarium is being formed through the efforts of between $I_{5}$ and 20 botanists, collectors, and foresters. We find upwards of 400 different tree species within a limited area; and it is estimated that from $I, 200$ to $I, 500$ different tree species will be found in the islands. Between 500 and 700 different tree species are brought into the market each year, of which about 40 are well known. A detailed study of these 40 species is being made, both by the botanists and foresters.

An effort is being made to study many of the native woods that are not well known in the market, but which occur frequently, and which the foresters report are not popular with the native lumbermen. To study these woods, a factory has been started at Manila as part of the work of the Bureau of Forestry, where some 40 or more Filipino cabinet-makers and carpenters work under the supervision of three American expert cabinet-makers. In this way a number of woods have been worked up in various ways so as to show their utility and beauty. The work of this factory is to be transferred to Bilibid prison, where I5O or 200 men will be employed. Foresters and lumber- 
men of each district are asked to send in samples of native woods which are found in large quantities, and which are not popular in the market, so that investigation may bring out some further utility or beauty which would make them more popular. The articles made from these woods are sold, thus helping to defray the expense of this investigation; at the same time a large number of Filipinos are being trained in the art of cabinet making.

Of the $48,000,000$ acres of woodland in the islands, there are at least 20,000,000 acres of virgin public forest. Valuation surveys by our foresters bring out the fact that in this virgin forest there is an average stand of 3,500 cubic feet of merchantable timber on each acre. It is safe to assume that there is at least I,500 cubic feet of timber on each acre which could be marketed at once, and probably much of the remainder, it will be found, can be used, after the investigation in our workshops is concluded.

We find no merchantable timber, and but very little woodland, close to the centers of population. Thickly populated islands, like Cebu and Panay, are almost completely stripped of their timber; and in many of the other islands the good timber has been cut away for about five miles from the coast line. In other islands we find the virgin forest extending down to the water's edge.

During the fiscal year 1904, about 50,000,000 feet B. M. of native timber were brought to market, while about $30,000,000$ feet of timber were imported from the United States, Australia, and Borneo. Much more timber would be used in the islands if the price were a little lower. The lowest grade of lumber is now worth $\$ 35$ to $\$ 40$ per $M$.

The forest wealth of the islands, especially in those 
parts where no operations have been carried on, is enormous. Large quantities of timber valuable for house and ship construction, cabinet woods, dyewoods, rubber, high grade of gutta percha, resins, and oils are found.

The display of Philippine forest products at the Louisiana Purchase Exposition, at St. Louis, Mo., was a revelation to the many visitors. None had realized the enormous quantities, size, and beauty of the native timber, and the great variety of other valuable forest products which the islands produce.

Up to the present, logging has been carried on in the same locality for a great many years, no effort being made to operate a virgin forest even a day's journey from the settlements. This has been due largely to the fact that in former times there was very little protection to life and property. The Filipinos prefer to live in settlements and work within a few miles of them.

Only one company in the islands has made preparations to $\log$ with modern equipment, and is now operating in nothern Negros. The first 20-year exclusive timber license to operate over a large area was granted to this company in August, I904.

The question is often asked, How much of the forests of the islands are held by private owners? Of the $48,000,000$ acres of woodland, much less than $I, 000,000$ acres are now in private hands. The forest law requires that all owners of private woodlands shall register their titles in the Bureau of Forestry before marketing the standing timber. If this timber is cut without registration of title, it is considered as taken from public land. Up to date, I32 estates, aggregating in area 270,000 acres, are registered in the Bureau. All owners of private woodlands throughout the is- 


\section{AMERICAN Forest CONGRESS}

lands have shown a desire to register their titles with the Bureau. The officials at our sixty forest stations throughout the islands keep a sharp supervision over the logging operations on private estates. The fear of confiscation of the land on account of non-payment of taxes, brings to the public notice the holders of all land in the islands. On account of the high prices of native timber during the past five years, all persons who claim any woodland have presented their titles for registration in the Bureau. But one large tract (50,000 acres), owned by the religious order known as the Recoletos, in the Island of Mindoro, has not been registered.

The private woodlands throughout the islands have been pretty thoroughly cut over during the past five years, and are not nearly so well timbered as the public forests.

The Bureau of Forestry has an office in Manila, which controls all operations in the forests, assisted by officials situated at the sixty forest stations scattered throughout the islands. These stations are so selected that the officials in charge of the district can readily supervise the operations of all persons gathering forest products.

The forest laws and regulations of the islands are based on provisions of the act of Congress of July I, I902, entitled "An Act temporarily to provide for the administration of the affairs of civil government in the Philippine Islands, and for other purposes." Sections $I 7$ and $I 8$ of said act provide as follows :

"Sec. I7. That timber, trees, forests, and forest products on lands leased or demised by the government of the Philippine Islands under the provisions of this act shall not be cut, destroyed, removed, or appropriated except by special permission of said government and under such regulations as it may prescribe. 
"All moneys obtained from lease or sale of any portion of the public domain or from licenses to cut timber by the government of the Philippine Islands shall be coverted into the insular treasury and be subject only to appropriation for insular purposes according to law.

"Sec. I8. That the forest laws and regulations now in force in the Philippine Islands, with such modifications and amendments as may be made by the government of said islands, are hereby continued in force, and no timber lands forming part of the public domain shall be sold, leased, or entered until the government of said islands, upon the certification of the forestry bureau that said lands are more valuable for agriculture than for forest uses, shall declare such lands so certified to be agricultural in character: Provided, That the said government shall have the right and is hereby empowered to issue licenses to cut, harvest, or collect timber or other forest products on reserved or unreserved public lands in said islands in accordance with the forest laws and regulations hereinbefore mentioned and under the provisions of this act, and the said government may lease land to any person or persons holding such licenses, sufficient for a mill site, not to exceed four hectares in extent, and may grant rights of way to enable such person or persons to get access to the lands to which such licenses apply."

A forest act was promulgated by the Insular Civil Commission May 7, 1904; and by means of its wise provisions, a rational system of forest management can be inaugurated and the future welfare of the forests secured. It received careful scrutiny from legal minds connected with the law-enacting branch of the Civil Government with a view to protecting and 
conserving the rights of the humblest licensee, while granting to lumber companies and heavy individual investors considerable latitude in timber operations.

The visit of Mr. Gifford Pinchot, Chief of the U. S. Bureau of Forestry, to the Philippines, resulted in much benefit to the forest service, due to his assistance in preparing the present forest act.

The forest regulations were amended to carry out the requirements in a forest act, and a forest manual containing both the forest act and forest regulations, indexed and annotated, with extracts from other laws bearing upon forest revenue or service, and some additional notes, were compiled and gratuitously distributed to all forest officials and licensees.

In the forest act, several important changes may be noted, which it is confidently hoped will give an impetus to forest development. Not the least of these is the reduction of tariff on forest products from about 60 to 35 per cent.; the reclassification of native woods into four groups; the adoption of the metric system of weights and measures in conformity with the revised U. S. statutes and similar action on the part of most advanced countries; the division of the provinces into two classes, $\mathrm{A}$ and $\mathrm{B}$, and granting of licenses for a period, within the discretion of the Secretary of the Interior and the Chief of the Bureau, not to exceed 20 years.

The liberality of these provisions may be seen at a glance, especially the first and last. In dividing the provinces, encouragement to licensees has governed action. The provinces in Class B are those in which it is desirable that the larger timber operations be carried on, and provision is also made for exclusive licenses, where the party at interest will have sole privilege of gathering a certain forest product on the area of public forest designated. 
It is cause for congratulation that at every step the Civil Commission has been in thorough sympathy with a rational forest policy. This is further shown by the public land act (926), which provides that public woodlands shall not be entered, sold, or leased until a certificate is received from the Bureau of Forestry that the land is more valuable for agricultural than for forest purposes. The removal of valuable timber from leased land is also subject to the regulations of this Bureau.

In order to take forest products from public lands, a person should make application to the nearest forest station for a license. If the license is for a small amount, the same may be granted by the local forest officer; if for a large amount, the application is forwarded to the Manila office, with remarks by the local forest officer. These licenses are usually granted in July of each year, and are usually for a period of one year. In cases where a company may desire to operate on a large area, a license agreement may be entered into for a period not to exceed 20 years, whereby the company secures an exclusive privilege to operate over the territory desired for the period stated. Before entering into this agreement, the officials of the Bureau make a careful examination of the territory desired, noting the character of the forest, facilities for logging, proximity of settlements, and also report just what logging operations are being conducted in this vicinity by the local residents. The officials of the Bureau will coöperate with representatives of any company desiring to secure data concerning the amount and value of forest products in any particular region where operations are contemplated. No charge is made by the Bureau for the examination, nor for the license granted.

The charges are made on the timber after felling. 


\section{AMERICAN FOREST CONGRESS}

The charges vary with the class of the wood and with the locality. In certain provinces, where the Government wishes to encourage logging operations, the stumpage charges vary from 75 cents to $\$ 3.75$, gold, per M feet, B. M., and in other provinces the charges vary from $\$ 1.50$ to $\$ 7.50$ per $M$ feet, $B$. $M$. In any locality of the islands, where a forester selects timber for felling, the lower prices will be charged.

During the fiscal year 1903-4, the following number of licenses were granted by the Bureau of Forestry:

Timber, 1,327; gratuitous, 905 ; firewood, 723 ; byproducts, 355. The timber licenses mentioned included I9 licenses granted companies. The total amount cut by these companies during the year was 640,327 cubic feet, an average of 24,228 cubic feet. The largest amount cut by one company was 95,016 cubic feet. The small amount cut may be accounted for when one realizes the primitive logging methods followed.

Much has been said for and against the Filipino as a laborer. When one is well acquainted with the native it is not difficult to learn the true inwardness of the difficulties of the labor problem.

In the first place the Filipino is apt, will do good work when supervised, and as a rule will continue to work if he is treated with some consideration.

The personal relations between the white supervisor and the native have much to do with the case. The native is accustomed to certain things that are simple and inexpensive but very necessary to him. He likes to have his family and fighting cock near him-he is fond of music, of his church, and of his people; in fact, he is fond of social pleasures and will work hard if he sees pleasure ahead. In the islands there have been a number of instances where we have employed 
several thousand natives under one management and where every consideration was shown them, and the results have been most gratifying. At the rock quarries near Mariveles, the workmen have their families with them; they are provided with horses, good food, and are treated justly and given their wages when due. The Depot Quartermaster of the Army in Manila employs between one and two thousand natives and reports very favorably on the work done. The engineers building the electric tramway in Manila report that the cost of laying each hundred feet of track in Manila averages less in cost than elsewhere; that the work is done well and that the labor is very satisfactory; and that there is not the slightest difficulty encountered in keeping the men to their work. The record made for coaling ships in Manila Bay made by the native Filipino was better than that of the Chinese or others employed in a similar capacity in the Bay.

The native Filipino will learn modern logging methods very quickly and well; he is keen at handling machinery, but needs some one to look over his work occasionally. The wage paid is of little consideration with the native. He may work for one man at 25 cents a day and refuse to work for another at $\$ \mathrm{I}$ a day. His employer may owe him several weeks' wages, but if the native is treated unjustly and his feelings are injured, he may disappear and say nothing about the wages due. If a company contemplates operations on-a large scale, the difficulty of securing a sufficient number of laborers will be minimized by starting in well. Give each family a small native house; bamboo is cheap. They should have their church, assembly hall, cockpit, and music, all of which can be secured at small expense.

The market for Philippine timber at present is 
Manila - a few cargoes are shipped to Hong Kong and Singapore. The war in the islands caused great destruction to property-the country people have lost their money and stock, their homes have been destroyed, the roads and bridges ruined, and now that an effort is being made to rebuild, there is but little money to pay for it; the people, the municipal and provincial governments are poor. Steady progress towards reconstruction is being made, however, and native timber is much used.

The Philippine timber is popular in the China market. All of lowland China is without timber and much is imported. Manila is nearer to China than any other country furnishing timber, and should in time furnish all of the construction and finer wood needed. A good market for cabinet wood should be found also in Australia, Japan, and the United States. The cost at the mill of native manufactured lumber should average less than $\$ 15$ per thousand, board measure.

The lower grade woods should then be sold at a fair profit and the higher grade woods at a much larger profit.

The legislation now requested of Congress looking towards railroad development in the islands, allowing municipalities to incur a certain amount of bonded indebtedness and reduction of the tariff will, if enacted, be followed by an era of railroad construction, municipal and provincial improvements, which means an increased demand for native woods. China is building railroads and yearly increasing its demand for timber. The Philippine market should take at least Ioo million feet of timber per year. Hong Kong, Shanghai, and Singapore should each take at least as much.

The average prices of timber per cubic foot and M., B. M., are, in Manila, as follows: 


\begin{tabular}{|c|c|c|}
\hline Class. & $\begin{array}{l}\text { In the log, } \\
\text { per cu. ft. } \\
\text { U. S. Cur. }\end{array}$ & $\begin{array}{c}\text { Sawed lumber, } \\
\text { per M. B. M. } \\
\text { U. S. Cur. }\end{array}$ \\
\hline$\ldots \ldots \ldots \ldots$ & $\$ 0.50$ & $\$ 141.25$ \\
\hline Molave ................ & .48 & 162.50 \\
\hline Narra............... & .47 & I28.15 \\
\hline Tindalo................. & .50 & I 43.75 \\
\hline Yacal................ & .40 & III.I5 \\
\hline Calantas...$\ldots \ldots \ldots \ldots$ & $.3 I$ & r56.50 \\
\hline Dungon................ & .40 & 100.00 \\
\hline Acle.................. & .37 & 85.00 \\
\hline Guijo................ & $.3 I$ & 80.00 \\
\hline Palo Maria............ & $.3 \mathrm{I}$ & 80.00 \\
\hline Apitong...$\ldots \ldots \ldots \ldots$ & $.3 \mathrm{I}$ & 60.00 \\
\hline Latuan............ & .20 & 48.50 \\
\hline Supa............... & .28 & $8 \pi .50$ \\
\hline Pasac $\ldots \ldots \ldots \ldots \ldots \ldots$ & $.3 \mathrm{I}$ & 81.50 \\
\hline Betis. . . . $\ldots \ldots \ldots \ldots$. & .56 & 94.00 \\
\hline Toog $\ldots \ldots \ldots \ldots \ldots \ldots$ & .18 & 62.50 \\
\hline Batino.................. & .16 & 75.00 \\
\hline
\end{tabular}

Prices Quoted IN MANILA NEWSPAPERS:

Class. Per M.B.M.,U.S.Cur.

Molave .............................\$160.00

Narra, R....................... $\quad \mathbf{1 5 0 . 0 0}$

Narra, Wh...................... 120.00

Yacal............................ 125.00

Ipil............................ I25.00

Guijo........................... 70.00

Supa........................... 90.00

Lauan.......................... 37.50

Apitong........................... 45.00

Oregon pine.................. $\$ 40.00$ to $\$ 51.00$

Redwood.................... \$47.50 to $\$ 71.00$

Hemlock................. \$40.00 and $\$ 41.00$

There are 3 good steam saw mills in Manila and one in northern Negros; a few smaller mills are in the 


\section{American Forest Congress}

provinces. The mills can saw all of the logs brought to market. The great difficulty is to get the logs. The system of logging must change, modern methods must be used, the donkey engine, wire cable, portable railways, and modern methods of rafting, loading, and unloading lumber vessels, all must be employed. Americans familiar with such work must be employed, and under their instruction a competent force of capable Filipinos may be trained who will learn quickly and will do a large part of the work required.

The Philippine Government is provided with just and efficient courts. A new judicial system has been inaugurated which gives satisfaction to all. Business men in the islands have a feeling of confidence in the courts which must be very gratifying to the Philippine Government. The Supreme Court is composed of seven judges, four Americans and three Filipinos, and all have been carefully selected for fitness and integrity. In cases involving $\$ 25,000$ or more, appeal may be made to the Supreme Court of the United States. All cases before the courts are tried promptly and the record of these courts would be a credit to any of our States. A system of registration of land titles has been adopted similar to that known as the Torrens system. The land court upon sufficient proof gives a title which is guaranteed by the Government. Purchases of land may now be made with the proviso that the seller secures a title from the land court.

The gold standard has been adopted for the islands so that the fluctuations in the currency so common in the Orient is done away with in the Philippines. There is and always has been since the American occupation, a surplus in the Philippine treasury.

The income to be derived from the new system of internal revenue is expected to more than meet any 
change in revenue from customs duties should the present tariff rate between the islands on the United States be reduced.

Ever since the American occupation of the islands attempts have been made by private capital to develop the lumber industry. Immediate success has not followed these efforts. In many cases sufficient capital was not invested; in other cases men failed through lack of experience in the business.

There is a vast natural forest wealth awaiting development, but its development requires wise management, money and time. This archipelago is the one undeveloped fertile spot in the Orient. The market for our products is strong and close at hand. Labor is not very difficult to secure, and ample protection is secured to life and property. The virgin forests have not been developed for this very lack of protection. Any company desiring to investigate the forest resources of the islands will find the officials of the Bureau of Forestry ready to coopperate in furnishing information, both in the office and in the field. There are a number of very inviting fields of forest development in the islands which should prove attractive to those who believe in the future of our possessions in the Orient. The following regions offer special attractions:

The Island of Mindoro, the east coast of Luzon, the Cagayan Valley, the Islands of Negros and Leyte. The greater the distance from Manila, the base of supplies, the less the chances for success. A company entering the Philippine field should go prepared to carry on some agricultural work in addition to logging; it should also be equipped with a modern saw mill, a complete system of water transportation so as to supply the island and China markets; it should have a lumber yard in Manila as well as in each China port. A well 
laid out town should be started for the employees. This scheme of exploitation can be started with a capital of half a million dollars. A tract of between Ioo and 200 square miles of virgin public forest may be secured for 20 years, and when secured a selection of the best sites for agricultural development should be marked out. Land may be purchased by the company and also by the employees, or may be taken up by them as homesteads. Philippine hemp and copra command a high price all over the world, are easily raised, and on virgin soil should produce good results within a few years.

The Philippines are centrally located and close to markets with a trade of more than Ioo million dollars per month; a trade that is constantly growing and that should be of great value to the islands. We have valuable and vast quantities of hardwoods; we have hemp, copra, sugar, and tobacco that 450 million people want. Manila will have next year the best harbor and docks in the Orient, and the facilities for loading and unloading large ocean steamers will make this port a great depot of supply for this part of the world. It seems strange that so many people should be unconscious of the great future of the trade in the Orient. China is awakening and will not cease its stride in commercial development. Japan will in the near future be a powerful factor in this development and will look to the United States for coöperation.

The Pacific is indeed an American ocean; we have the choice islands in the great sea, we have the most fertile spot at the gates of China. This spot is peopled by a bright, ambitious, and happy race, a race that is susceptible of great development. The Philippines need Americans with a keen sense of right and justice, with brains and money, the American coming to the 
188

Proceedings OF THE

islands should realize that it is the country of the Filipinos, he should treat the native with consideration and the ready response of the native will be more than gratifying. Business will succeed in the islands if the native is with you. 


\section{THE LUMBER DEALERS' INTEREST IN FOREST PRESERVATION}

\section{BY \\ GEORGE W. HOTCHKISS}

Lumber Becretary's Bureau of Information

THE very interesting papers to which we have listened this morning may well give me some excuse, in the lateness of the hour, for cutting my remarks short, and I request the chairman to call me down in ten minutes at the outside. Representing the retail lumbermen of twenty-four States which were gathered in the early part of December, and about 40,000 retail lumbermen, I come to you to bring their greetings and to say something about the interests of the retail lumber trade in connection with the preservation of the forest. In order to arrive at an adequate realization of the interests of the retail lumberman, which means the interests of the nation at large, it is necessary to take a hasty glance at the progress of the lumber business.

The first saw mill in this country was built in 1643 in the forests of Vermont. In 1763 we began to import lumber from Canada, and we have custom house figures to show that 623 feet were brought to Oswego in that year. The center of the lumber trade progressed west to the straits of Mackinac, and the island of Mackinac was for a time the center of the industry; from that point to the St. Clair River and to the Saginaw River and to Lake Michigan points in Michigan and in Wisconsin, with several different points of production. In the early settlement of Mich- 
igan we begin to find mills on the St. Clair. They throve in the '3os, increased and with the settlement of the country the lumber industry of the State spread until it covered the entire State. At about the same time there were a few mills on the shore of Lake Michigan in Wisconsin and on the Wisconsin River. In 1830 the city of Chicago received its lumber by ox team from the Alleghany Mountains. The consumption of lumber in 1883 was $2,225,000,000$ feet-a contrast with the load brought by the ox team in 1830 . In 1852 I went to Canada, returning from California, and began the manufacture of lumber on the north shore of Lake Erie. Here a strip from Port Hope on the east to Port Stanley on the west represented the area of lumber operations. In I862 I went to Saginaw, remaining there seventeen years. In those year, speakof values, I bought lumber which ran 75 per cent. upper for $\$ \mathrm{I}_{4}$ a thousand feet. Those uppers to-day, were they still to be had, would be worth $\$ 85$ to $\$$ Ioo in Chicago. This is the increase in value. In I870 in connection with Henry S. Dow I became the original lumber journalist of the country, and from that time I have been greatly interested in statistics of production. I have often found great difficulty in obtaining reports of statistics of manufacture, but we have so perfected the system of statistics as to have arrived at a fair knowledge of the production of the country. In 1870 and thereabouts, after many experiments confined wholly to pine-for in those days the lumberman knew nothing about any lumber except pine-it was determined that the consumption averaged 500 feet per capita. Some put it at 494 feet, some at $5 \mathrm{IO}$, in the several years during which these figures were compiled. The per capita consumption to-day is not less than 750 feet, including all varieties of tim- 
ber. We are using trees that we used to think worthless. We are sawing everything that will make a board and some that will not, and as Mr. Defebaugh has said, you will find $4 \times 45$ with bark on all four corners. As was a common expression in the days of the war, we are "robbing the cradle as well as the grave." We are paying no respect to age or value of timber, but are cutting it down and getting rid of it.

The consumption to-day may fairly be estimated at from $46,000,000,000$ to $50,000,000,000$ feet of timber annually. I remember a young man with grand prospects for lumber manufacture who told me he had secured an option on 360 acres and wanted to build a mill on it and asked me for my advice as to how to make \$25,000 profit. I told him that that amount of timber would be just a good week's bite for some of the modern saw mills and that the mill would never be paid for by the profits. A great many people have the same inability to understand big figures and the immensity of the lumber business, but when I tell you that the consumption of lumber during a single day is something like $13,000,000$ to I $5,000,000$ feet you will perhaps get some appreciation of the vastness of the lumber trade. It is claimed by Government authorities that the lumber industry is the fourth in extent. I claim it to be the first. I claim the value of the vast industry has given us one-fourth to one-third of the financial value of the country. Our financial interests are computed at $\$ 96,000,000,000$. I believe the forests have given us from $\$ 25,000,000,000$ to $\$ 30,000,000,000$ of that amount, and where is one other industry that exceeds it? So little is understood of the value of the lumber trade that I must give you one little illustration: The product of the California gold field I have watched with interest, having been a forty-niner. Our produc- 
tion of gold in California from 1848 to 1890 was $\$ 1,348,000,000$. The lumber trade of the nation for I890 was $\$ \mathrm{r}, \mathrm{I} 35,000,000$, lacking but $\$ 200,000,000$ of the entire volume of gold produced in California, which has been the gold mine of the world during all these fifty years. Let me give another illustration. All the products of the soil, including oil, gold and ironeverything of that kind-in 1895 was $\$ 540,000,000$, with a wheat crop of $\$ 400,000,000$. There you have a total of $\$ 940,000,000$ for the products of the soil against $\$ 1,135,000,000$ for the products of the forests. I claim that lumber is the productive factor in the wealth of the nation.

$U_{p}$ to about 1870 the lumber business was transacted by the manufacturer and the wholesaler at leading deep water centers, and by but few retail yards. When I took my first clerkship in New Haven, Conn., in 1874, our lumber supplies came from Maine and afterwards from Albany and the Susquehanna at Fort Deposit. Then a part of the manufacturers drifted west, and in $185^{2}$ purchased timber and manufactured it in the southern part of Canada. Gradually the production has extended westward. We had originally in Michigan not fewer than $300,000,000,000$ feet of white pine, of which we had cut $165,000,000,000$ feet up to 1897 , with less than two billion feet left in that year by reason of forest fires and other destructive influences. The total production in the northwest to 1897 , in Michigan Wisconsin and Minnesota, was 333,000,000,000 feet. These are figures that are representative of the immensity of the lumber business. This is a billion dollar country as far as its finances are concerned. It is much more than a billion foot country to the lumbermen. This lumber has been utilized by the railroads and we have built the nation from the forests of the 
North. My time has expired and I have no time to exploit the forests of Pennsylvania and the West, but could I do so, I think I could fully demonstrate that we are a lumber consuming people and strengthen any impression you may have formed of the importance of the trade. 


\title{
COOPERAGE AND ITS RELATION TO FORESTY
}

\author{
BY \\ JOHN A. McCANN
}

Editor National Coopers' Journal

$\mathrm{A}^{\mathrm{S}}$ a preliminary measure of enlightenment and to they relate to the subject of improved forest conditions, I may say without fear of contradiction that the writer of that beautiful poem, "Woodman, spare that tree," has never been a very popular personage in cooperage circles. Indeed, I think it will be very generally conceded, even by manufacturers of cooperage stock themselves, that no class of timber workers have been more indefatigable and painstaking in their efforts to make the work of the American Forestry Association and the Bureau of Forestry a prime and pressing necessity than have those amongst whom it has been my pleasant and, more or less, profitable privilege to labor for many years.

This being the case, it would seen to require a rare and rather robust quality of courage for one who has for twenty years conducted a cooperage paper to come here for the purpose of offering congratulations on the fact that in future we are likely to have intelligent and scientific efforts to prevent the enthusiastic labors of those who seem bent on leaving nothing of our American forests but a memory. That I am here for that very purpose, however, would seem to indicate that I have that able-bodied quality of courage with me, but as a plea in extenuation or avoidance, which- 
ever is preferred, I will say that I come primed and fortified with the belief that

\section{"Long as the light holds out to burn, The vilest sinner may return."}

And in this particular direction we cooperage people have sinned atrociously.

Now, ladies and gentlemen, I shall not follow my journalistic associate of the American Lumberman, Mr.' Defebaugh, in the erection of any pedestals on which to place cooperage people. I shall not follow him in picturing my cooperage friends as natural and patriotic conservators of our forest areas. I shall not deny that we have been wasteful, nor shall I seek to defend that wastefulness, nor shall I discuss the question of man's right to do with his own just what he sees fit. I come simply to lay our symptoms, as I see them, before Dr. Wilson, Chief Surgeon Pinchot, and their assistants, with the hope that they can successfully prescribe for our ailments. It is only the sick that require a physician, and on that hypothesis I fail to see why Editor Defebaugh, as the representative of those well-behaved and immaculate lumbermen, came here at all.

We cooperage people make no claims of that kind. We have been wasteful, and as though in pursuit of the most lofty ambition, we have for years gone at the destruction of at least two of the noblest specimens of the American forest, the white oak and the American elm, and followed them so relentlessly, that the ends of both are well in sight, unless the American Forestry Association or Bureau of Forestry will stay the hand of the stave man, do something to repair his wastefulness, or satisfy his rapacity with other woods of which a greater abundance is obtainable. 
It may be news to many of those within the sound of my voice that grades of white oak, which are welcomed by the furniture factories of Grand Rapids and elsewhere for furniture making, would be rejected by the maker of the whiskey barrel, and that elm, suitable for the interior finish of a luxurious home, would not always do for a Minneapolis flour barrel. We of the cooperage fraternity are both finicky and fastidious; but it is earnestly to be hoped that under the operation and influence of this Association the Bureau of Forestry, or the legislation which will follow their joint recommendations, some of this fastidiousness may be taken out of us.

As far back as I have any knowledge, white oak has been, and it is to-day, the chief dependence of the tight barrel cooper. I mean those who manufacture barrels for whiskey, wine, oil, alcohol, turpentine, and other liquids. All of these seem to demand and require white oak of the finest grade, and the part of the tree which they deem fit for their purpose is its least part.

The greater part, up to recent years, has been thrown aside to rot and breed a very destructive species of worm, or else has been thrown into heaps and burned. I feel that I am well within the bounds of truth and reason when $I$ say that if all the white oak which has been wasted during the past fifty years could have been saved and sold at its present value, it would have been enough to pay for the Panama Canal, or possibly pay off the national debt.

There are other woods used by the tight-barrel maker for such semi-liquid products as syrup, glucose, lard, pork, etc., and these woods include cypress, red oak, and latterly, red gum. Chestnut has never been made much use of in this country, although it is used extensively for olive oils in Italy, as well as in the wine 
districts of France and Germany. The American family of chestnuts is a large one, and if it could be demonstrated that some of the varieties are available for tight-barrel work, it would have an excellent effect in restricting the demand for oak, the supply of which -in any considerable bodies-is now confined to Kentucky, Tennessee, Arkansas, and Texas. The availability of tupelo or red gum for tight-barrel purposes, is another work which the Bureau of Forestry could undertake advantageously, as from a recent bulletin issued by the department, it is learned that in the district south of the Ohio River and east of the Texas line, red gum stumpage alone equals that of all other hardwoods combined.

In seeking to prepare myself to point out for this Association and the Bureau of Forestry where either or both can possibly be of use to the industry which constitutes my field of labor, I have called upon some of the manufacturers of cooperage stock for their views on this subject, and one of these, who is a close student of forest conditions, and particularly well fitted by nature and education to speak intelligently of cooperage needs from the standpoint of forestry, says that the cooperage people who own timber, and timber owners generally, should be educated to their necessities in three ways:

First. The need of an intelligent appreciation of the value of timber.

Second. The need of caring for the timber from a physical standpoint.

Third. The manner in which to accomplish these ends.

To begin with, the first subject means to teach the public an intelligent appreciation of the value of timber. It is an old maxim that "Wilful waste makes woeful 
want." Timber owners should know the value of their holdings, and in the event that they do not want to make use of them themselves, and do not want them to come into the hands of their neighbors, then the obligation which rests on every good citizen should not be overlooked, and that is, the sacred duty of caring for material things which are to pass on down to posterity.

Taking the physical view of the matter with reference to the cooperage business, it has come under my observation, says my correspondent, that each year white oak for cooperage stock is becoming scarcer, and the quality of the oak is deteriorating. Worms in the timber are becoming more destructive and working in new localities, and in this connection I would add that worms do more serious damage to white oak, so far as cooperage is concerned, than they do to any other kind of timber.

It seems that the great quantity of waste timber allowed to lie in the woods and decay accounts, to a great extent, for the increase of worms in recent years, as this decaying timber not only feeds the worms, but breeds them as well.

Another destructive force that I want to speak of, which has destroyed many million feet of fine forest, is the annual fires that we have in the different timber belts. These fires not only kill the small timber outright, but the larger trees are blasted, and as soon as they begin to decay the worms entirely destroy the tree. The need of protection against both of these destructive forces can easily be seen; indeed, the way was well pointed out yesterday by an Ontario delegate; and this brings us to the third subject: "How to Accomplish These Ends."

In this connection I am greatly interested in the matter of forest reservations to be purchased and 
owned by the Government. I would like to see our Government own large boundaries of timber lands in different sections of our country, and to give these forests such care and attention as would demonstrate that to give care and attention to standing timber will prove as great a source of revenue as any other line of endeavor of which demonstration can be made. Let the Association and the Bureau of Forestry acquaint the public with the fact that each year timber is becoming. more valuable, and should have their attention in the way of protection against the two destructive forces, viz., forest fires and worms. Let the Government make practical tests and demonstrations in their own forests by piling up the great quantity of waste timber and by cutting down and burning decaying timber, thus destroying the germs of the worms as well as the worms themselves; and the other object in cleaning the forest of this waste matter is to put safeguards around to prevent forest fires.

Another large exporter of cooperage stock and lumber suggests that laws similar to those which now exist in France and Germany, where replanting would be practically compulsory, should be put on our statute books. He believes that it is only a question of time when it will be rendered necessary, by conditions, for the United States Government to insist on replanting, where owners cut over timber, and practically to adopt the French and German law, or practically the same forest laws that exist all over Continental Europe and which are, undoubtedly, well known to the Bureau of Forestry.

Another believes that it would be a great advantage to the country at large if forests of elm (elmus Americana) and cottonwood (populus monilifera or populus balsamfero or balm of Gilead) were planted under 
governmental auspices. These species grow very rapidly, provided they are planted in low, wet land; and there is an abundance of such land that would grow forests of this class of timber, if properly planted and protected from fire, thereby utilizing, to the best advantage, land that is practically worthless for other purposes. All other classes of deciduous woods (excepting the white or burr oak species) which are now used to considerable extent for cooperage, can be grown on hillsides and other lands which are not valuable for agricultural purposes.

Some of my cooperage friends are of the opinion that the time has passed when this Association, the Government or its Bureau of Forestry, can render any practical service in this direction. A very large operator in Michigan writes as follows: "I know of nothing that the Government can do, except to encourage reforestation as much as possible, as I believe the Government owns practically no timber lands on which cooperage material is now growing, and as the timbers used for cooperage material are now in the hands of private holders, the question of handling this class of forest products in a more economical way, with less waste, is entirely beyond the jurisdiction or dictation, in any way, of the general Government.

"There is a great deal of wasteful extravagane, especially in the South at the present time, in the way of not taking out of the timber tracts all of the timber that might be used, which wastefulness is, in a large degree, practiced on account of the low stumpage cost at which most of these properties were acquired.

"The question of reforestation of the kinds of timber used for cooperage material is a large one, and it is going to take a great deal of time. These kinds of timber grow much less rapidly than pine, and many 
of the other timbers that are used so largely for general building and manufacturing purposes.

"It occurs to me that really one of the chief things in connection with this question is to discourage the useless waste of the kind of material used for cooperage. Any subject of this kind naturally concerns almost entirely the private holder of stumpage, and is therefore beyond anything the general Government could do, except to make suggetsions. The principal manufacturers, possibly, would not be interested in even any such suggestion as this to the general Government, from the fact that for some time past it has been apparent to them that the time was speedily coming when material suitable for cooperage is going to become quite scarce, consequently more valuable. Hence they are willing to let those who are so disposed be as wasteful of such timber as they please. Of course this is a very selfish view, but selfishness travels hand-inhand with the commercialism which seems to have possession of us at present, to an extent not believed possible in the days of our forefathers and the blessed era of "The Simple Life."

Another correspondent, who is a large manufacturer of staves in Arkansas and Louisiana, and who is also a close student of all matters pertaining to his craft, writes as follows:

"In my opinion, little can be done by the Bureau of Forestry that will benefit the cooperage manufacturers in business to-day. The subject of reforestation is, and has always been, an interesting one, and I am glad to note that it is being taken in hand, and that the people have at last awakened to the necessity of taking some steps toward insuring the supply of timber for use in future years. Experts claim that it takes an oak from 80 to IoO years to arrive at its maturity, or its 
prime, rather; and from this age up to 400 and 500 years is about the ages of trees that are usually consumed in cooperage. You will readily see from this that unless the present timber supply is very much greater than most of us admit it to be, that the supply in sight at the present time will be exhausted long before any new supply could possibly come in. To advocate trying to curtail the cutting, to my mind, would be altogether futile, as there is hardly an acre of virgin oak timber to be found in the county anywhere to-day. True there are some considerable tracts which are usually called virgin timber, but the fact of the matter is that nearly every acre has been cut over to some extent, and in some cases so long ago that the signs of the original stumps have disappeared.

"There is no doubt but what the cooperage manufacturers have been the worst timber butchers who have ever visited the hardwood forests of any country. In some places we find tracks of the destructive methods that prevailed many years ago, of cutting only the choicest trees to be found, and making them into very large staves for export, using nothing but the very choicest part of the tree, and only the choicest trees in the forest at that time. This is still being carried on, to some extent, and I have in hand a letter advising me that the Louisiana Commission has ordered an especially low rate on logs and heavy staves for export (that is pipe and cask staves), overlooking the fact that by so doing they are just contributing to the denudition of the better parts of the forests, and causing them to disappear much quicker than they would otherwise, leaving a large portion, which the average stave manufacturer of to-day would class as first-class material, to decay in the woods. As to what would be of benefit to the stave manufacturers: we 
think that some restriction or some kind of embargo thrown around this rough, unfinished product going abroad would be of some value in the way of preserving the forests as well as assisting the cooperage manufacturers of to-day in the pursuit of their lawful business.

"Reforestation will have to be conducted under the supervision and at the expense of the general government, if done to any valuable extent. Any other scheme will fall short of its mark, and in my opinion the best way to get at that would be for the Bureau of Forestry to secure tracts of land known to be suitable for the growing of oak timber and no other hardwoods. Buy or secure tracts of reasonable size, go over and replant a considerable area, under the charge of an expert forester. This would be somewhat of a kindergarten, and would encourage the planting and culture of timber by individuals, and improving lands that had already been cut over and otherwise practically valueless. The remission of taxes by the states and the bonuses by the Government in view of planting and cultivating trees in certain countries, would materially assist in the reforestation of tracts that would otherwise be long left barren. It is a fact that the best oak lands are being rapidly put into cultivation for corn, cotton, and other products of that nature, and the uplands of hill lands, formerly so productive, have been turned into valuable farms, and are consequently of more value to the owner than the timber proposition.

"As a rule, the stave manufacturers of the country have not been buyers of timber until recent years, except as stumpage, and consequently they have had no interest in the preservation of the forests and want to get only what is suitable for their purpose.

"As there is only a comparatively small territory in 
which oak timber now grows-that is, in the Southern States and the eastern part of Texas-and seeing that it has been reduced to so small an area, it is undoubtedly very important and necessary to the welfare of the country in general, and the industry that we are engaged in particularly, that the scheme of reforesting this section on comprehensible and intelligent lines be instituted as early as possible."

What I have touched upon thus far relates most closely to the tight-barrel feature of the cooperage business, which is really the least important branch of the industry, in volume, if not in dollars. The slackbarrel department comprises the manufacture of barrels to contain loose or dry products, such as flour, sugar, cement, lime, fruit, truck, and other things far too numerous to mention. It is to this branch of the cooperage industry that we must charge the annihilation and destruction of our elm forests. Their hand is stayed in that direction at present, to some extent, simply because there are now no forests of elm to conquer, and all of this havoc has been wrought in about twenty-five years. Up to that time the slackbarrel people were at work on a contract to destroy all the red oak in the country, as at that time oak was the chief timber used in slack packages, especially for flour and sugar. Owners of elm timber, purchased for a song, taking advantage of the advancing market for oak, sought to prove to the barrel men that elm was, at least, as good as oak for their purpose, but the innovation was looked upon with little patience. Finally, however, it was proven conclusively that elm was a better timber for this purpose than oak, and for twenty years and upwards it has been practically the only timber used for slack-barrel staves and hoops. The supply, however, is about exhausted, and now the 
enterprising owners of gum timber tracts, bought as cheaply as elm was twenty years ago, are trying to persuade the cooper to forsake elm and accept gum, and in this praiseworthy undertaking the Bureau of Forestry can render efficient aid by demonstrating how gum may be most effectively utilized, and wastefulness discouraged; and now is the time that this work should -be undertaken. One of my contemporaries says that "it is the traditional policy of consumers of lumber and timber to ignore the possibility of the exhaustion of the timber supply, and invariably they fail to realize that fact until it has actually taken place." That suggestion fits my cooperage friends exactly. Twenty-five years ago elm and oak were as plentiful in the Northern States as gum and oak are in the Southern States now, and while that condition exists the campaign looking to conservation of the supply should be entered upon vigorously and determinedly, while the campaign for reforestation of the denuded lands of the North should also be organized and pressed with earnestness.

With all the pessimistic sentiment surrounding this question of depleted timber supply, however, there comes to me one ray of light, and this leads me to the belief that the situation may not be quite as black as it is painted. Looking back into the files of my paper of eighteen and twenty years ago, I note news items in which it is stated that this manufacturer of staves and that manufacturer of heading, located in portions of Michigan, Wisconsin, Indiana, and Ohio, "are seeking new locations, because the timber supply is exhausted." The strange part of it is, in looking over current issues I find that now, twenty years after, the same manufacturers are pegging away in the same place. The explanation of this is found in the axiom that "Necessity knows no law." These manufacturers 
had cut out the largest and best of their oak, elm, and basswood, but rather than seek a new location they concluded that perhaps they could use trees less than two and three feet in diameter, and so they stayed to cut them. After these were gone, they noticed that there were some mighty fine maple and beech trees left. Well, they cut the largest and best of these, and now they are at work on the other ones-not so large.

Necessity has compelled us to see that beech, maple, and birch will take the place of elm and basswood for slack-cooperage work, and we are also learning that gum will make the best of barrels, when handled properly, and I presume that there are other timbers growing in our forests that only need intelligent handling to become equally as available. Whatsoever the American Forestry Association or the Bureau of Forestry can do to demonstrate this, to prevent waste and destruction by fire and parasites, and to renew supplies, will be work well done, and which will go far to justify the establishing and support of such a department of our Government. If $I$ have furnished anything of suggestion that will aid in that work it will be a source of gratification, not only at the present, but in the future, when the beneficent work of the Bureau has had time to make itself apparent. Indeed, much has already been accomplished, and while $\mathrm{Mr}$. Defebaugh has paid a just and proper tribute to the worth and work of Secretary Wilson and Chief Pinchot, I cannot allow this opportunity to pass without saying a word for missionaries like Dr. Hermann Von Schrenk and others who have carried the war "into Africa," and gone out to preach the gospel of forest preservation and restoration among the heathen. Their work has been good and effective work, as the success of this Congress fully attests. 


\section{PART IV.}

IMPORTANCE OF THE PUBLIC FOREST

LANDS TO GRAZING 



\title{
PRACTICAL RESULTS OF THE REGU- LATION OF GRAZING ON THE FOREST RESERVES
}

\author{
BY \\ A. F. POTTER
}

Bureau of Forestry

I $\mathrm{N}$ the administration of the National Forest Reserves, one of the first matters of importance which the Government has been called upon to settle, is the proper adjustment of grazing privileges. It has often happened that in the establishment of forest reserves the customary ranges used in pasturing live stock have been included and consequently the stockmen have been directly interested in the rules and regulations and the policy which was to be adopted in their administration.

At first there was considerable doubt as to the practicability of such regulation of grazing and stockmen feared that the restrictions imposed would be detrimental to their interests. The sheepmen were alarmed because at first the rules excluded this class of stock entirely from all reserves except those of Oregon and Washington, and consequently they strongly opposed the creation of forest reserves elsewhere which included large areas of grazing land. By investigations which followed it was found that in many of the reserves total exclusion of sheep was unnecessary, but that a limited number of this class of stock could safely be allowed under such restrictions as would prevent injury to the forest and insure a proper use of the range. The regulations were therefore so modified 
as to permit sheep grazing under such circumstances.

The Government realizes the importance of the live stock industry to the prosperity of the Western commonwealth and the fact that a very large proportion of the people are directly dependent upon it for the support of their homes.

The great economic value of the forage products of the forest reserves is also realized, and an effort has been made to use this resource in the way which appears to be best for the interests of all concerned.

Care has been taken in the preparation and enforcement of grazing regulations to avoid, as far as possible, any unnecessary disturbance of business by sudden changes! in the manner of using the grazing lands. 'An effort has also been made to fit the regulations to the actual needs of the reserves and to allow every privilege consistent with their proper care and management.

In the settlement of questions concerning the use of products of the reserves all of the different interests must be recognized and considered. The stockmen must not expect to be allowed to use the grazing land in a way which would be seriously detrimental to the interests of the farmer depending upon the water supply from the reserve for irrigation, or which would destroy the forest growth. The lumberman must also consider these interests and the future welfare of the country, and be willing to cut and handle the timber in a way which will insure a continued growth of the forest. The farmer must not expect the Government to entirely stop the grazing of live stock or the cutting of timber, but must be content to have these things done under a proper system of regulation.

Whenever it has been found that modifications or changes in the regulations were needed such action 
has been taken as promptly as opportunity has offered the means of ascertaining the facts in such cases.

Investigation of the ranges has shown that damage caused by live stock is usually due to overstocking, grazing too early in the season, or the manner in which the stock is handled, all of which can be directly charged to the previous lack of any system of management rather than to the sheep or cattle.

Overstocking has undoubtedly been by far the greatest cause of range destruction and decrease in its carrying capacity. Under the free range system of the west there has been very little restriction as to the number of stock anyone had the privilege of pasturing on the public domain. The result has been that the ranges in many different localities have been very badly overcrowded and have rapidly declined in their pasturing value.

Some of the ranges which were included within the forest reserves have been overcrowded with live stock, in some sections with sheep and goats, and others with cattle and horses, until the excessive use of the range had resulted in injury to the young growing forest, and great damage to the forage plants and grasses.

On the creation of forest reserves in such localities in many cases the full number of stock, both sheep and cattle, which were then ranging there, have been allowed permits during the first year, and afterwards as it was found necessary. The number has been gradually reduced from year to year until a limit was reached which would allow as full utilization of the forage as possible without injury to the range. The result has been that by such management many of the badly overgrazed ranges have been greatly improved in condition and grazing value, and are fast being restored to their former usefulness. 
The damage from sheep grazing was found to be largely due to the manner in which they were handled, although there was some sign of browsing young trees over the entire areas which had been overstocked. The injury from this cause was not usually serious except along routes of travel used in moving sheep from one range to another, or in the close vicinity of lambing grounds, and old camps.

In places where the sheep had been camped on the same bed ground for a long time, perhaps a month or more in the same place, the grass and forage would be completely eaten out for a mile or so around, and many of the young seedling trees eaten or nibbled by the hungry stock. Damage by this system of handling is usually entirely unnecessary, and is detrimental to the best use of the range, as well as injurious to the forest. As the necessity for better management in the use of the range has become apparent, stockmen have fast realized the destructiveness of this method of handling sheep, and have adopted the plan of never bedding them more than two or three nights in the same place, and in some cases never driving the sheep to a bed ground at all, but allowing them to camp wherever night overtakes them, thus reducing the damage from this cause to a minimum, and, in fact, almost entirely removing it in many cases.

The forest reserve regulations on this point require that sheep must not be bedded more than six nights in the same place, and the practical result of the application of this rule has been to improve the condition of many portions of the range.

One of the greatest evils in the destruction of forage on the summer ranges is that of driving the stock in too early in the season, while the feed it yet immature. Lack of range control is usually responsible for this condition. 
If the number of stock to be driven to the mountains for pasture exceeds the number there is sufficient pasture for, there is often some particular section of the range which one man desires to secure ahead of his competitors, and in the struggle to get there first the stock are driven along as fast as possible and destroys as much feed by tramping as they consume in feeding. In some sections this competition for range continues during the entire season, and, of course, results in great destruction of forage as well as damage to the forest and water supply.

Immediately upon a range coming under forest reserve control, the damage from this cause is checked and a better use of the forage results. Under this system of management the dates upon which stock will be allowed to enter and on which the season will close are designated, and the ranges are divided in the manner which appears most practicable, so that each stockman who is granted a permit, knows just what portion of the range he will be allowed to use, and when he can drive his stock in. Furthermore, he knows that on arriving there he will not find the range already occupied by someone else, consequently, there is no need for any haste in driving, and the stock are grazed along in a way that causes little damage.

It has been found in some cases that ranges which apparently were greatly overstocked have shown a marked improvement in condition by the application of the grazing regulations without any reduction in the number of stock, other than the exclusion of transient herds, showing clearly that the damage was due largely to the manner in which the stock has been handled.

In the competition for free range, controversies have 
arisen between the cattlemen and sheepmen, or between large and small owners of stock, which have sometimes resulted in open warfare with an occasional homicide and great loss of property. The degree to which this warfare has been carried has been governed largely by the demand for the use of the range. In the first occupancy of the lands by stockmen, the ranges would usually be divided by mutual agreement in a way which would give each sufficient pasture for all of his stock, either sheep or cattle, and if the seasons continued favorable there would be no occasion for any serious dispute concerning its use. If, however, a certain portion of the range was drought-stricken and there was a consequent scarcity of feed and water, the stock belonging to the occupants of that portion of the range would naturally drift over on to the neighboring ranges where conditions were more favorable. As long as this did not result in overcrowding to the extent that all of the stock became thin in flesh, there might be a little grumbling, but no serious trouble would arise. Whenever it was plainly apparent, however, that such intrusion upon the ranges was causing financial loss, the first step taken was usually to notify the owners of the stock to remove the same and provide feed and water for them elsewhere. In case of refusal on the part of the owner, there being no law for the settlement of such matters, the next step would be an attempt to remove the stock by force. Just what resistance would be offered was, of course, always a very hard matter to foretell; sometimes no trouble would arise, and at other times it would result seriously.

Owing to the fact that sheep are herded and cattle usually turned loose, the sheepmen have had an advantage in the use of the public grazing lands because of 
the fact that they had their business under a better system of control. In case of lack of feed or water in any particular locality the sheepman could immediately move his stock to other and better pasture, while it was necessary for the cattleman to round up or gather his stock before any such move could be made, and this often meant an entire season's work. The result has been that where the use of the range has been unrestricted the number of sheep has increased more rapidly in proportion than the number of cattle, and in some localities the sheepmen have taken possession of the range to an extent that it has become almost impossible for the settlers to find pasture for their small bands of cattle.

The result of forest reserve regulation has been to settle these controversies so far as the grazing lands within the reserves are concerned, and an important step in the advancement of a better system in the management of grazing lands has been made. After an investigation of the claims presented by the stockmen and a careful consideration of all interests concerned, the Government has defined the privileges to be granted to each opposing faction. In some cases it has been thought advisable to exclude sheep from portions of certain reserves and allow cattlemen the exclusive use of such areas. In such cases, however, whenever it has appeared that it was necessary for sheep to cross closed areas in being driven from their customary ranges to points of shipment or between summer and winter ranges, driveways have been provided to meet the necessities of the demand and allow the proper handling of the stock. In other cases the reserves have been divided into districts in which sheep and cattle have been pastured jointly, the number of each class allowed being restricted to what was 
considered a fair division in the use of the range. It has been found that oftentimes a better utilization of the forage has been obtained in this way, as there would be portions of each district which were better adapted to the pasturing of one class of stock than the other at certain periods of the season, and that sheep would eat many little weeds and plants which were not touched by cattle, and cattle many of the coarser grasses which the sheep did not feed upon. As long as the total number of each class of stock is restricted to the actual capacity of the range and each stockman knows such to be the fact, there is no trouble between the different owners, and all soon realize the benefits and appreciate the value of this system of control.

One of the greatest causes of forest destruction throughout the West has been fire, and the prevention of fires is one of the most difficult problems in the management of the reserves. Just how far the stockmen have been responsible for the destruction of the forest by fire is a hard matter to determine. Burning to clear out the brush and undergrowth so that cattle could have free access to the grass, and burning the old grass in places where it had not been grazed off, for the purpose of securing a new growth of green feed, have been resorted to in past years, but these customs have been almost entirely abandoned on account of their general destructiveness.

A large proportion of forest fires start from camp fires, which are thoughtlessly left by campers, prospectors, hunters, and stockmen. It is of great importance that the unnecessary destruction from this cause be realized and every precaution taken to reduce the prevalence of fires started in this way.

The reports of the forest reserve supervisors show 
that the number of fires starting from camp fires left by. stockmen or for which stockmen are in any way. responsible has decreased from year to year, and also that the stockmen have been the most willing volunteers and rendered the most effective service wherever assistance was needed in fighting forest fires starting from any cause. On account of their presence on the ground, so that service could be rendered on short notice, stockmen have greatly assisted the forest reserve officers in saving large areas of timber from destruction by fire. It seems fair to say that one of the practical results of the regulation of grazing has been the establishment of a strong and effective volunteer fire service.

The stockman has learned from experience that forest reserve protection of the summer ranges means an improvement in the condition of his stock and an increase in the profits of his business. During the past season when stock in many range sections suffered severely on account of lack of food and water, those who were fortunate enough to have pasturing privileges in the forest reserves were able to get their stock fat. While many of the outside stock on overcrowded ranged remained thin in flesh, the result being that the stock pastured on the forest reserves were in better demand and sold for more money than those from the outside ranges.

As the policy of the Government becomes better understood and the benefits to be derived from judicious management of the grazing land is shown by practical demonstration, the opposition of the stockmen to the creation of forest reserves will be entirely removed and they will coöperate with the Government in the proper regulation of grazing and the permanent improvement of the ranges. 


\title{
THE PROTECTION OF HOME BUILDERS IN THE REGULATION OF GRAZ: ING ON FOREST RESERVES
}

\author{
BY \\ E. S. GOSNEY \\ President Arizona Woolgrowers' Association
}

$\mathrm{THE}$ home was the foundation of the first laws of the foundation of every independent government of the people by the people. The necessity of the fullest protection of the homes of our country and the builders of these homes is seldom realized and never overestimated.

By "home-builders" we do not mean the dwellers in palaces of wealth and luxury, nor do we mean the shiftless nomad. But we refer to that great class of honest, loyal Americans of limited means who have a substantial appreciation of home and country. Those people whose highest ambition is to build a home of their own for themselves and their families where they can live in comfort, frugal independence, and happiness. Such homes have given us our Lincolns, our Grants and our Garfields. They have given this country its high place as a nation among nations. They include all classes and grades of intelligence, education, and refinement. Honest purpose is the only requisite to bring them within the class of homebuilders. A man's capacity, energy and environments determine the character of the home he will build; but on the protection of such homes, the development of their integrity and patriotism, depend the life of 
the nation and the protection of our property and person.

Such citizens demand careful, patient consideration, whether encountered in the mines, factories, and farms of the East or on the mountains and plains of the West. And this is especially true of the Western forest reserve management, because it embodies a radical innovation on their customs, rights, and life.

Many persons dwell in the towns, villages, and the country throughout these reserves and in the irrigated and unirrigated districts below and about the reserves. They are cattlemen, horsemen, sheepmen, farmers, or miners, as the case may be, and the confidence and coöperation of each of these men, especially the stockmen, is necessary to a full protection of the forest reserves and a full realization of the high purposes of forestry. The administration needs their confidence and coöperation, and they need the protection of fair, just, and intelligent regulations and management in the grazing as in all other regulations for the protection of their interests in whatever class they fall.

President Roosevelt, standing in the pine forest on the rim of the Grand Canyon of the Colorado, a few months ago, said of our Arizona forest reserves, "Use them for grazing, for farming, for lumber, for whatever they are best adapted, but so use them that you will not destroy their usefulness for future generations." And in his heart every man in that audience said, "Amen." The difference comes only when you attempt to decide what use is harmful and what use is protective in its results, honest differences as yet unsettled, and usually the theorist who rushes over the reserve on a hurried tour of inspection or rides through on a train at forty miles an hour is the most positive as to necessary regulations and results. 
It is unfortunate that in connection with the creation of forest reserves there have been opportunities through the "lieu land" laws and the railroad grants for lands for private speculation running into millions of acres and multiples of millions of dollars which have naturally been taken advantage of, and in the manipulation of these schemes every means, in Washington and out of it, has been made use of. Men have made it their business to go among the people and agitate with extravagant theories and spread false representations by public and private statements and subsidized newspapers, to the great injustice and damage of all grazing industries, especially sheep, and of every interest affected except the scheme that was covered with this veneering of pretended interest in forestry. In this way public sentiment was created favoring extended forest reserves where no forest existed, more "lieu lands," and incidentally more speculation and bitterness and distrust among the people and toward the cause of forestry.

The field work in connection with forest grazing regulations is new and necessarily handled in many cases by inexperienced and overconfident representatives. Many crude and unjust rulings and damaging regulations have been the result of the over-confidence of such representatives. Range allotments must not be arbitrarily changed on the protest of one party without notice to others interested and due regard to water rights and the carrying capacity of the ranges. Stock trails must not be established with regulations that would damage the interests involved and constitute a fit subject for the attention of humane societies to prevent cruelty to the animals confined to such trails without adequate feed or water. Regulations as to water development must not discourage and retard 
rather than protect and encourage such work in arid regions. To assure this the field inspector must be a man of experience and exceptional ability, and the office force at Washington must not only be good men, as they are, but they must be given an opportunity to learn these conditions and to study in the field the methods of handling stock, lest in overcoming one difficulty they create others they know not of. The people interested must be fully advised and consulted as to such regulations, then the facts and results will be understood and mistakes avoided. It must be remembered that the mass of the people familiar with the range conditions can see no excuse for such mistakes, and believe them to be the result of a reckless disregard of their interests and rights. There must be closer relations between the stockmen and home-builders, and the forest officials. Their representations must be frank and open; they must know one another. If there are conflicting interests the parties must be brought together and no contest settled on an ex-parte hearing. Before any radical change is made, the interests affected should have a hearing, and candor, honesty and frankness should be recognized and due appreciation shown, while selfish misrepresentations and willful disregard of regulations and the rights of others should be sufficient cause for ridding the reserves of this irresponsible class of men. We spend millions annually educating the children. We should give some time and attention to the conservative education of citizens in and about forest reserves, likewise to the training of rangers and administrative officers in the interest of harmony, of intelligent appreciation, and of the necessities of the requirements and changed conditions.

The general principles recommended by the Bureau 
of Forestry a few years ago and endorsed by the Secretary of the Interior, but not yet put to practical use, were sound as a basis. Some day these principles and regulations now being worked out for the control of grazing on forest reserves will be carried out in all or most of the public grazing lands with such modifications as may be found necessary in each locality; and the regulations for each locality must be governed by local conditions. The chief danger is too great haste, over-confidence.

There is no real conflict of interest between the home-builder on the irrigated ranch and the homebuilder in the forest reserve, with his cattle or sheep grazing on the public lands. Whatever destroys the productiveness of the soil, whether too many stock, bad management, fire, or recklessness in any manner, damages all. The stockman largely consumes the product of the farm and the farm provides the necessaries of the stockman. The conflicts between cattle and sheep interests are the clashing of individual interests and not of the two industries. The very food they eat is different. Cattle eat the grass, sheep the weeds of the range when left to their choice. If the individuals can be brought together and calmly talk their differences over, 90 per cent. of such evils will disappear.

I shall not attempt to lay down a code of regulations for grazing on forest reserves or off of them. The man or men who attempt to fix in advance anything more than the general principles of such regulations will fail. Let us remember that it has required more than half a century to build up the mining laws and regulations of our country, imperfect as they still are, and they were all based upon and grew out of a few general principles and simple rules agreed upon 
by a handful of sturdy prospectors and miners who gathered about their California campfires sixty years ago. Their problem was simple compared to the grazing problem. If these men could not then devise a perfected system applicable to the varied interests that the subsequent development of the mineral wealth of our country have presented, how can they devise rules and regulations for all climates and conditions of grazing? These must be the growth of experience in each locality, the slow evolution of the industry from which the speculator and the theorist must be eliminated.

For some reason the average expert, examining the forest or range on any point of policy or use, seems to feel called upon to keep his business a profound secret, especially from those settlers whose experience and observation in the locality, form one of the necessary premises of logical, correct conclusion and report. These methods tend to create and develop a spirit of distrust between the settler and the official, instead of confidence and coöperation. This criticism is not applicable to all, but is quite prevalent and calls for a radical reform in methods. The pioneer stockman or settler knows more about his own range than any expert and he must be reckoned with in any final solution. The average expert on forestry or grazing operating unaided in a country new to him is one of the most fallible men I know, however honest or extensively drilled in technical schools.

Much depends upon the supervisor of a forest reserve, who must be a strong man, with plenty of common sense. He must not be opinionated or unduly sensitive. He must be a man of character, a judge of men, and ever ready to learn from the most humble and illiterate home-builder, and to patiently advise 
and guide such people into the correct lines of thought and action. I fully realize such men are not plentiful, but they exist and must be had, and when found, and by experience educated, should be retained. They in turn must be guided by a more wise and inspiring administration at Washington. Give the home-builders in and about these forest reserves an administration in which they have full confidence, one whose officers do not get out of humor and write petulant and uncalled for letters and orders before they thoroughly understand the facts; an administration which always consults the people as to the people's needs and fully advises them as to the supposed needs of the forest and the objects of any and all restrictions. When this confidence is established and a few unruly and disturbing elements are judiciously amputated from the body of stock grazers you will have among stockmen and home-builders a class of forest protectors worth more to the service and to forestry than all the rangers the government can employ, a class of men you cannot hire.

Perhaps the most dangerous element the people are facing to-day on the grazing question, whether in the forest reserves or on the public domain outside, is the land and stock monopolies. I speak of these with hesitancy, knowing that my position will be misunderstood and misconstrued by many. Among these large stock and land companies are some of the ablest and best men of the country; many of them are my friends; most of them are employed on tempting salaries to look after the interests of these large companies; employed because of their splendid abilities, their character, and influence; and, like faithful advocates, they are doing their duty most admirably. The time was when there was little or no conflict between these 
interests, and the few small stockmen and homebuilders. Then came the "rustler," who, tempted by opportunity, appropriated the cattle and stock of these companies along with parts of the range, and I am sorry the "rustler" is not yet extinct. But the public lands of the West are rapidly filling with real homebuilders, and these large ranges, outside of the Mexican grant lands and private holdings, must be given up to the use of the settlers. We, whose stock feed in large pastures and cover large areas of public lands, must gradually give way to the smaller home-builder; and I regard the change as no individual calamity, but as a part of the evolution of the greatest country and best government civilization has known.

The powers that control these large companies and employ our friends, their advocates, will give up with reluctance and only at the end of a hard struggle. To this end Congress has been besieged with lobbies and bills for the leasing of the public domain, and for the exchange and consolidation of the railroad grant lands all in the interest of these monopolies, but shrewdly and ably covered up a veneering of some benefits to the public, real or imaginary.

These measures are dangerous because of the money behind them, of the ability and character of their advocates, and because of the sincerity of some begotten of the study of one side only, and chiefly because, for the most part, but one side is represented in the contest. The home-builders are busy with their home affairs; individually they have neither the means nor training necessary to meet the arguments of the interests that threaten them. They have no organization and, in fact, few of them know what is being done for or against their interests; but let some of these deceptive, unwise, and unjust measures pass Congress, which 
will deprive the honest home-builder of a just proportion of the public range about the home he has built, or is building, and you have sown in the heart of that home and of every humble home in that community the seeds of discontent and distrust and have gone one step back toward anarchy.

The discussion of this question cannot be limited to the forest reserves; and they tell us the land suitable for the home-builder is all gone; that there is no more farming land and it is time the Government should classify what is left, dispose of grazing lands for grazing purposes, and "go out of the land business." No statement could be more incorrect or misleading. We are just beginning to learn the value and use of the land of the West.

Some years ago the founder of a great land and stock company was driving with a boy through the great San Joaquin Valley of California. They saw a team plowing in the distance and drove on. After courteous salutations, the conversation ran like this :

"Are you preparing to put in a crop here?"

"Yes."

"What kind of a crop do you think you can raise in this valley?"

"Wheat."

"How long have you been in this country?"

"About three months."

"I thought so."

"Don't you think I can raise wheat here?"

"I know you cannot."

"How long have you been here?"

"Thirty years."

"I thought so."

This is not a story created for the occasion. It is a historical fact. The boy is one of the honored mem- 
bers of this Congress. His companion was one of California's most able and eminent men, a mental athlete who failed, after thirty years of experience and observation, to classify the great San Joaquin Valley as agricultural. In view of such experiences, what must we expect of any expert or commission charged with the classification of the vast areas of arid lands. What could the expert have told you of the oil wells of California and Texas thirty years ago?

With the rapid development of irrigation and water storage with governmental aid, and with the development of water from beneath the surface scarcely begun, the future possibilities of the deserts, valleys, and plains of the Western domain are yet beyond our comprehension, and the Government should hold fast these titles for the home-builders of the future which will come with these developments.

Through each step of this evolution we must remember the absent home-builders of little means and limited opportunities, and zealously protect their opportunities for the future against the encroachments of the strong and aggressive, if we expect them to raise up patriotic sons and daughters who will perpetuate this as a just and free government; the grandest heritage we can leave to our posterity, to humanity. 


\section{ADVANTAGE OF COÖPERATION BE- TWEEN THE GOVERNMENT AND LIVE STOCK ASSOCIATIONS IN THE REGULATION AND CONTROL OF GRAZING ON FOREST RESERVES}

\section{BY \\ FRED P. JOHNSON}

Secretary National Live Stock Association

A SSUMING that it is conceded that the forest reserves may be used in an economical manner for the grazing of live stock, the absolute necessity of an efficient control and regulation of this privilege, for the protection of the reserves, must be admitted.

To those not familiar with the vast areas the forest reserves cover, the task of providing an efficient patrol to guard them and prevent their injury, may seem a mere matter of detail. Those who are familiar with these conditions, on the contrary, are inclined to the belief that the whole United States Army would hardly furnish enough men to give the adequate protection needed. While, under the present system of patrol, a small army of men are in service, the protection afforded is only nominal. How then can the stockmen be allowed to graze in these reserves with the assurance that they will be rightly used, and not only the grazing, but the forests as well, be protected from misuse and vandalism, for there is vandalism in grazing as well as in the destruction of forests?

From my knowledge of the stockmen in the West, I can assert that there is no class of men more vitally 
interested in sane and reasonable forest protection than the stockmen. If given an opportunity, no class of men could furnish more absolute and reliable protection for these reserves. But would they do it? Yes, if properly approached in the matter.

The western stockman is of a peculiar disposition, due probably to his environment. Restless and impatient under any attempt to bind him to iron-clad rules and regulations, yet, when approached with a request for help and assistance, even though he may derive no benefit, he is quick to respond. It has been the failure of governmental departments to understand this phase of his character that has resulted in much opposition to forest reserves. As the pioneer, who braved the dangers and hardships of the frontier to open the way to civilization, he has felt that he had acquired some moral rights which even the Government should respect, and to have a stranger ride up to him while on the range and dictate to him things that he may or may not do, even though spoken in the name of the Government, is galling to his pride and that feeling of absolute freedom which has been bred into his nature. Approached by the proper officials with an explanation of the necessity of the forest reserves; the good that will eventually result to him from their establishment, and a request for assistance in maintaining them and carrying out the plans of the Government, would meet with immediate and hearty response.

All over the West there are organizations of stockmen who have associated themselves together for the protection of their interests and for the improvement of conditions in their industry. These organizations are composed of the leading and progressive stockmen in the various districts. These are men who are building homes in the desert and they are profoundly inter- 
ested in anything that affects the prosperity of their locality. Here, already organized, is an army of men greater than any the Government could press into service for this purpose, ready, willing, effective, and to be had for the asking. The Government has only to request that in return for the privilege of grazing on these reserves, that the organized stock association assume the task of protecting them, fostering the vegetation and preventing fire and vandalism. It is possible that many of them do not thoroughly understand the problem the Government has undertaken to solve; then they should be enlightened, and it would be found that there would be no more enthusiastic supporters of the reserves than the stockmen.

It must not be understood that I advocate the complete turning over of these reserves to the stock interests. The Government control and supervision must be absolute, but the organized stockmen could be sworn in as forest officers. They should have at least an advisory voice in the making of the rules and regulations and in return should be given as much freedom in the use of the reserves for grazing purposes as would be consistent and in keeping with the objects to be attained.

The advantage of such coöperation between the government and stockmen must be evident. The advantage to the Government is to enlist the active assistance of men who live on the ground, as it were, in the advancement of the forest reserve idea. Under such an arrangement the reserves would have a better protection than could possibly be obtained in any other way and at the minimum cost for administration. Instead of the antagonism of a large class of citizens who really have rights that the public is morally bound to respect, you will have their enthusiastic support. This, 
in my mind, is worth much. On the other hand, the stockmen are made to realize that these reserves are being maintained for the benefit of the community in which they live, and they, having secured a personal interest in the success of the idea, will do their utmost to build up the reserves along the lines desired. While they are given the right to use the reserves for grazing purposes, the privilege will not be abused under such conditions, for the community, being interested, will permit no abuse.

The time to inaugurate the proposed plan is at hand, since the reserves have passed into the control of the Department of Agriculture, through the recent passage of a bill by Congress transferring the administration of the reserves from the Department of the Interior. The Department of Agriculture is closer to the stockman than any other department of the Government, and now that the transfer is accomplished it will be an easy matter to secure this coöperation.

It is unnecessary in a paper of this kind to go into the details of a plan to secure this coopperation. It is a perfectly simple matter, and where there at present does not exist live stock associations to take up this work, they would be quickly organized when it was understood that the Government was willing to recognize them and accept their assistance in the building up of the reserves and in the maintenance of their safety and integrity. As to the question of the wisdom of adopting the policy suggested, it seems to me that there can be no negative argument worth considering, none at least from those who understand the actual conditions in the West. 


\section{NECESSITY OF USING THE FOREST RE- SERVES FOR GRAZING PURPOSES}

\section{BY \\ SENATOR FRANCIS E. WARREN}

President National Woolgrowers' Association

F OREST protection in the United States by Government interposition is of recent origin, dating from March 3, I89I, when in the act to repeal the timber culture laws, a section was placed conferring upon the President authority to set apart and reserve public lands, wholly or in part covered with timber or undergrowth, whether of commercial value or not, as public reservations.

If the law authorizing the creation of forest reserves had been enacted half a century earlier, the people of the United States would to-day be richer than they are by billions of dollars, the value of countless acres of timber wasted in the ruthless rush for earlier development of the country and destroyed by fire for want of adequate protection, mainly the latter.

The forestry reserve law which took the place of the timber-culture law (under which nine millions of acres of public lands passed into the ownership of individuals), is simple in terms and occupies but brief space in the statutes. But its effect has been far-reaching, and under it has grown up in the brief period it has been in existence a new and important branch of governmental administration.

The forest reserve law has been taken advantages of during every year since its enactment for the creation of forest reserves, excepting during the years I894, 
1895, and 1896. During the other eleven years the law has been in operation the several Presidents have issued proclamations creating fifty-nine forest reserves, embracing $62,763,494$ acres, an area so great that comparisons are necessary in order to obtain an adequate conception of it.

If the various reserves were assembled in one compact tract, the aggregate area would be greater than that of the great State of Wyoming; greater than the area of Michigan, of Oregon, of Utah, of Minnesota, or of Nebraska. It would be greater than the combined area of all the New England States, with New Jersey and Delaware thrown in for good measure, and it would be greater than New York and Pennsylvania combined.

The primary object of the creation of forest reserves was that the timber supply of the country might be husbanded and preserved, and that the denudation of the great timbered areas of the country, which was progressing with fateful rapidity, might be choked. But with the creation of the reserves a more important object was evolved, and that is the preservation of the water supply. I cannot better describe this object than by quoting from the message of President Roosevelt to Congress at the opening of its present session:

"This" (the preservation of the water supply) "is their most important use. The principal users of the water thus preserved are irrigation ranchers and settlers, cities and town to whom their municipal water supplies are of the very first importance, users and furnishers of water power, and the users of water for domestic, manufacturing, mining, and other purposes. All these are directly dependent upon the forest reserves."

The beneficial object of the withdrawal from unre- 
stricted public use of the forest lands of the West and their creation into reservations, has the endorsement of residents of Western States, even though the public land area of those States is seriously diminished. The Western people, patriotic in all things, acquiesced in the intrenchment upon their States for the general public good. Although the creation of forest reserves and forest regulations often work hardships to individuals and to communities, there is no branch of the Government which has more loyal support from Western citizens than has the forest service.

That there have been earnest complaints concerning it cannot be denied. That these complaints were just is evident, for the two great administrative arms of the Government, the Department of the Interior and the Department of Agriculture, have taken cognizance of them, and have provided remedies for many of the complaints, until now there is a fair degree of harmony between the people directly concerned by forest reserve regulation and the forest service.

The complaints which have attended the administration of the forest reserve law grew out of the mistaken notion of many minor officials, and of some whose places were quite high on the official roster, that the reserves and what they contained were to be withdrawn from public use. They acted in their dealings with those living on or near the reserves on the theory that the timber, the grass, the water, and even the air, was reserved for the use of the Government and such of its official servants who might happen to have their abiding place, temporarily or permanently, on the reserves.

Happily, this idea of withdrawing the reserves from all use has, year by year, lost its potency. Investigation, examination, and experience demonstrated that 
the reserves, by judicious use, could best be preserved, and the welcome words of President Roosevelt, in his latest message to Congress, coincide with the views which have been held by Western citizens since the creation of the reserves, and they illustrate also how closely and clearly the President is in touch with Western needs and interests. In his message he said:

"It is the cardinal principle of the forest reserve policy of this administration that the reserves are for use. Whatever interferes with the use of their resources is to be avoided by every possible means."

The most serious complaint lodged against the administrative regulations of the forest reserve was in reference to the restriction (in the earlier days of the reservations, amounting to almost prohibition,) of live stock grazing on the reserves.

While the restrictive regulations were applied to all classes of live stock, they were particularly and almost viciously severe in reference to sheep. And, while it may not be germane to my subject, it might be noted that the poor sheep and the still poorer sheepman have been the object of hostility of mankind almost since the beginning of recorded time. The first attempt to put a sheepman out of business was when Cain slew his brother Abel, who "was a keeper of sheep." Even the great John Randolph, it is said, declared "that he would walk a mile out of his way any time to kick a sheep."

And this innate antipathy to sheep and sheepmen found expression in the earlier regulations which the officers of the forest service saw fit to put into effect for the care and protection of reserves. With little or no practical knowledge of the subject, they held the sheep to be the most destructive animal in existence. If allowed within the forest reserves, it was charged, 
this ravenous creature would not only eat the grasses found there, but would feed on the shrubs and shoots, and if hunger were not fully appeased by this diet, would climb the trees and devour the tender branches. If allowed to cross the reserves, it was claimed that the sharp hoofs of the sheep would cut and pack the spongy forest soil so that floods and serious soil erosion would follow and forest reproduction would be endangered. Then, too, it was charged that the herders would leave camp fires uncared for and that fire and destruction would follow in the wake of the shepherds and their flocks.

It took many years for the Western stockmen to convince the officials in Washington that sheep do not climb trees and do not eat coniferous plant or tree growth, which forms the greater part of timber of Western reserves. It took much effort to convince them that grazing off the heavy growth of weeds and wild grass in the many parts of the reserves was the best protection that could be provided against the spread of fires. It has taken much demonstration to convince them that it was more to the interest of the stockman than any other class to protect the reserves against fire and that scarcely an authenticated case could be found where a forest fire originated purposely or carelessly with a stockman.

There have been exceptions to this class of officials. Two notable ones occur to me at this time, the present Commissioner of the General Land Office, and the Forester of the Department of Agriculture.

Following the advient of these officials into the forest service have come reforms along practical lines which have the sanction and approval of the President and the warm welcome of the woolgrower and stockman.

These reforms have been along the lines of more 
stringent regulations for policing and patrolling the reserves, more liberal regulations for permitting settlers to obtain timber for their own use, more liberal regulations concerning live stock grazing and sheepcrossing permits, careful investigation of the character of the lands before including them in forest reserves and in the investigation of lands previously included with a view to restoring them to public entry and settlement, if found more valuable for grazing or agriculture than for growth of timber.

These reforms followed the earlier onerous regulations and were the result of petitions for relief sent to the Department of the Interior from individual settlers and ranchmen, stock associations, stockgrowers, and irrigation congresses, and of personal requests for a more liberal attitude towards Western people made by members of the Senate and House of Representatives from Western States.

During the year just closed sheep were allowed to enter and graze in twenty-one forest reserves, and cattle and horses in fifty-five, while in I90I but eight reserves were opened to sheep and thirty to cattle and horses. In 1904 there were issued 843 sheep grazing permits allowing $1,806,722$ sheep to enter and graze on the reserves as against $39 \mathrm{I}$ permits and I,214,4I8 sheep in Igor.

During last year 5,874 permits for cattle and horses were issued and 620,657 head of this class of live stock allowed to graze as against I,926 permits and 277,62I head of stock in 190I. During the year ending June 30, 1904, 919,225 additional sheep were allowed to trail across the reservations in going to grazing grounds or shipping points outside of the reserves.

To more correctly make known the necessities of using the forest reserves for grazing purposes a refer- 
ence to forestry in my own State-Wyoming-would not be out of place, as conditions there are typical of conditions generally.

When Wyoming was admitted to statehood in 1890 its area was 62,64I,920 acres. Since that time over ten per cent. of the area of Wyoming has been withdrawn from public settlement and created into forest reserves. The State has given up for the general public good an area larger than the State of Massachusetts, larger than New Hampshire, or New Jersey, or Vermont, or Maryland. There has been no serious complaint on account of the great area thus withdrawn and reserved, but there has been complaint as to indiscriminate early withdrawals of great tracts of land not forest, but grazing lands. There has been complaint also that grazing restrictions in the reserves were too severe and that a much smaller number of live stock was permitted to enter the reserves during the grazing seasons than the parks and open spaces in the reserves would carry without detriment. There has been complaint that the bureaucracy of the forest reserve administration caused unnecessary delay in the granting of timber cutting permits and that many matters that should be settled by local officers had to be referred to Washington, thus causing much needless delay and inconvenience to the ranchman and stockman.

Some of their complaints have been given due consideration and reforms inaugurated to remedy them. The Commissioner of the General Land Office, in charge of the administration work of the service, and the Forester of the Department of Agriculture, in charge of the scientific features of forestry, took cognizance of the complaint that lands were included in reserves regardless of their character and conjointly conducted investigations and examinations to remedy this evil. 
An investigation was made of the Yellowstone reserve, the largest in the United States, which required I IO days and I,800 miles of travel by a skilled engineer and forest expert and their assistants. As a result of their investigation they recommended the elimination from the reserve of 559,350 acres of grazing and agricultural lands and the addition of 130,560 acres of outside timber lands, making a net reduction in the reserve of 428,800 acres. This recommendation was approved by the Commissioner of the General Land Office and the Forester, and the change in the reservation area directed by presidential proclamation. A similar investigation was made of the Big Horn forest reserve, Wyoming, which was reduced in size by eliminating 65,000 acres.

I am of the opinion that still more liberality could be shown in granting grazing privileges without detriment to the objects for which the reserves were created and with great benefit to those living within the vicinity of the reserves.

Wyoming has many resources. It is one of the leading coal producing States of the Union. It has shipping mines of copper and iron. It produces oil of superior quality and in great quantity. Its building stone is used in many outside States, and it has as many farms in proportion to population as any State in the Union. But the chief industry of Wyoming is the raising of live stock, and under the conditions which have prevailed for nearly half a century, grazing on the public domain constitutes the principal method of live stock raising. To arbitrarily withdraw from general public use an area of over 7,000,000 acres, which is perhaps twenty per cent. of the public grazing lands of the State, would seriously endanger this great live stock industry if needlessly severe regulations were 
kept in force for the control of the reserves. It is, therefore, a necessity that good judgment be exercised in granting grazing privileges so that the fullest measure of capacity of the reserves may be accorded the live stock interests, at the same time guarding against forest injury. In my opinion the reserves of Wyoming, the forests of which are all of coniferous growth, would bear without injury a decided increase of live stock during the grazing season.

Complaints have been made justly from time to time of the refusal to allow stock to be trailed across the reserves for shipment or to reach grazing grounds on the public domain. These complaints have, in a large measure, been remedied, but there is still room for improvement.

The conditions in Wyoming apply generally to the entire Western country, and the needs of the sheepmen and other live stock owners in relation to the forest reserves are general and may be summarized as follows:

First: Thorough and complete topographic examinations should be made of all forest reserves with a view to restoring to the public domain all grazing and agricultural lands, and all lands covered with timber of non-commercial value and valueless as a protection to watersheds or the headwaters of streams, or for the protection of water supplies for cities and towns.

Second: Adequate public trails should be established across forest reserves so that sheep and other live stock might be moved across the reserves to reach grazing grounds, markets or shipping points, with the least possible inconvenience to owners.

Third: The grazing capacity of each reserve should be estimated by local officials, who should take into consideration the actual conditions of grass growth 


\section{American Forest Congress}

each year, and the reserves should be opened during the grazing seasons to the full capacity of the reserves, consistent with their preservation and the prevention of over grazing.

Fourth: The administration of the reserves should be placed, as far as possible, in the hands of local officials, and the rangers, supervisors, and superintendents should be, when practicable to obtain them, local men familiar with local conditions and requirements.

Fifth: Grazing privileges on the reserves should be confined to stock owned by taxpayers and ranch owners in the State in which the reserve, upon which the grazing is sought, is located.

I am satisfied that the inclination of the present officers of the Government in charge of the forest service is favorable to the granting of these several necessities of the grazing interests, and I believe now that a law has been enacted by Congress for consolidating the control of the reserves under the Department of Agriculture, the needs and necessities of stockmen in relation to forest reserves will receive earnest and impartial consideration. 


\title{
SHEEP GRAZING IN THE FOREST RE- SERVES FROM A LAYMAN'S STANDPOINT
}

\author{
BY \\ L. H. PAMMEL
}

Professor of Botany, Iowa College of Agriculture and Mechanic Arts

I HAVE been somewhat interested in forest matters for a good many years, not only from the standpoint of the subject of this article, but also from the standpoint of a botanist. I have followed somewhat closely the range problems for fifteen years, and my work has brought me in contact with it from Texas to Montana. I have been deeply interested in this problem, for the Iowa farmer needs to recuperate his stock for feeding purposes from the great arid regions of the West. No stock equals the western range animals for feeding purposes. It is, therefore, to the interests of the Mississippi Valley that good conditions shall be maintained on the Western ranges. I shall not stop to review the various interests concerned in connection with the forest reserves of the West.

Four interests must be considered (1) grazing, (2) timber supplies, (3) irrigation, (4) mining. Each must be brought together in one harmonious whole. The breaking of any one of the links in the chain cannot but affect the others. During the early development of the West one interest only was the dominating one, that of mining. It was soon found that some lines of agricultural pursuits were needed to give stability to the country. Then came a conflict between the different lines of agriculture-the irrigator, the sheep 
herder, the cattleman, all seemed to be in irreparable conflict. Happily, however, through the efforts of Mr. Gifford Pinchot some of these matters are being settled in an amicable way.

It has been my good fortune to have spent some time in the Rocky Mountain region of Colorado, Wyoming, Utah, and Montana, partly to investigate some of these problems and partly as a layman to enjoy the benefits of the mountain air and to study the flora.

What were some of the conditions in the great pasture fields of the Rocky Mountains and adjacent regions from 1897 to 1901 ?

The cattlemen were dissatisfied because their ranges were more or less injured, the irrigator complained of lack of water. The sheepmen alone entered no general complaints except where the competition was too strong among themselves. The open ranges which had offered abundant opportunities at first became poorer and poorer and the sheep had to seek greener fields in the mountains during the summer. What was more natural than that they should make use of the forest reserves, where in small parks and meadows grew an abundance of nutritious grasses. When the permits were first given it was supposed that grazing would be confined to the parks and meadows. But the spirit of this regulation was probably never adhered to, since the competition among sheepmen was so strong that they had to seek all kinds of feed for fear of their flocks reaching the point of starvation in some cases. It was my privilege to examine three of the forest reserves, the Uintah, Big Horn, and Bitter Root.

The Bitter Root forest reserve, in Montana, is a ragged range containing a large amount of timber and several important streams, the water of which is used to irrigate the fertile fields in Montana and Idaho. 
The timber in this region is somewhat different from that occurring in the Uintah Mountains. There are large bodies of murravana and pinus yexilis. Spruces, balsam and the Douglas fir are found at different altitudes. This region is very different from the Uintah Mountains topographically. Sheep grazing has never been permitted here, and there are few parks. It is essentially a forest region. Let us first, therefore, consider the importance of the mountains in respect to the water supply for irrigation.

No better natural reservoirs can be found anywhere in the Rocky Mountains than the many lakes located at the sources of the larger streams rising in the Uintah Mountains. In addition there are many basins or ancient glacial lakes that contain vegetation well adapted to hold the moisture and thus release it in the form of springs. The flow of water from these springs is regulated by the amount of water held in the soil or retained by the humble plants growing in forest, meadow, and park. Hundreds of these meadows occur in the reserve, their continuity being broken only by stretches of forest. A study of these meadows shows a large number of plants important in the conservation of moisture. Through decay these plants form a rich humus which, owing to the peculiar physical conditions, undergo decomposition slowly. Hence this soil is highly retentive of moisture.

The bogs always carry an abundance of moisture and the meadow, under natural conditions, generally contains water, but under overgrazing or the effects of forest fires the meadows are damaged to such an extent that the water during the summer months is continually diminishing.

The present diminished water supply is due in part to injudicious grazing. Is the water supply less than 
formerly? So gaugings of the streams have shown, as does the testimony of old settlers. Two factors have been important in bringing about these changed conditions. First, an unusually large part of the reserve has been burned over. Prior to 1879 small patches had been burned over by the Indians and trappers. Large areas were burned by the Indians in 1879. Since then there have been many destructive fires, burning many thousand acres. During the early settlement of the country some of these fires were started with the idea of making better grazing, but experience has taught owners of sheep and cattle that the burning of forests does not improve the range. Fires in this reserve, as elsewhere, are started carelessly. Sheep herders have been given the credit for starting these fires, but I believe they should not be held responsible. More fires are started by hunting and fishing parties than by cattle and sheepmen.

Bitter controversy has prevailed for years among cattle and sheepmen and those who use the water for irrigation purposes. The latter nearly always agree with the cattlemen in regard to the destructive work of the sheep in the reserve. In some cases the criticisms are justifiable. A few illustrations may be cited. During the winter of I899-I900 there was an unusually light fall of snow in the mountains with a light rainfall in the summer of 1900 . Forage was scarce, so short that the meadows at high altitudes were stripped of their plants, and the forests were denuded of their undergrowth as much as the meadows. Lower down in the reserves the valleys of all the streams looked like sheep trails with dust rising in clouds even in the woods. The sheep had to resort to willows, potentilla fruticosa, betula glandulosa, quercus, prunus demissa and aspen for their forage. These were 
stripped of their foliage as high as the sheep could reach. The similar species were entirely denuded. Sheep are said not to graze on conifers, but in numerous cases the Engelmann spruce, Lodgepole pine, balsam, and Douglas fir were stripped of their foilage as high up as sheep could reach. In that year the grazing privilege was granted to 180,000 sheep, a number far in excess of what the conditions warranted. The number actually grazed was probably still larger. In I901 and I902 the conditions were very much improved.

So many sheep in the reserve cannot help being injurious to the forest. The indiscriminate grazing in the burnt timber destroys the herbaceous plants and keeps the small shrubs in an enfeebled condition and thus prevents the renewal of the forest.

In no case did I observe young pines where fires have occurred during the last eight or ten years. But in timber nearing maturity, and even mature timber, the injury was great. The herbaceous plants are injured to such an extent that reseeding is impossible. Seven years ago herbaceous plants were in abundance along all of the brooks. Now, however, they are confined to the headwaters of the streams and plentiful only just below timber line. Many valuable grasses were once abundant, but now have become rare because the plants do not have a chance to reseed the ground since the roots are destroyed by tramping and close grazing.

In order that sheep owners may have a longer lease of the forest reserve the suggestion has been made, by those who are interested in the sheep grazing question, that every sheep owner who receives the privilege from the Government should be compelled to reseed the ground with grass seed and let the grazing go on 
as before. This is not necessary. I believe under existing conditions it is practically impossible for grass or any other plant to get a good start. But given an opportunity the pasture and meadows will recover.

After spending three seasons in this reserve, I am convinced more than ever that the number of sheep in it should be regulated by wise and judicious rules laid down by the Department of Agriculture, subject to change as the Department may from time to time deem expedient, or entirely prohibited until the forest is in a better condition. The solution of the problem is a difficult one under the present conditions. Public opinion in Utah and Wyoming is decidedly in favor of unrestricted grazing privileges regardless of consequences. So long as the Government pursues the present policy in regard to the semi-arid lands so long will the question remain unsettled. In my opinion the leasing of the semi-arid lands for a term of years will help partly to solve the question for the forest reserves. The free use of our public domain for every one destroys the range to such an extent that the sheepmen are forced to use the forest areas. Free ranges should be abolished.

In the Bitter Root forest reserve, although larger quantities of water are used than formerly, the water supply from the mountains is scarcely diminished so far as I have been able to learn. The most important factor in the Bitter Root forest reserve to be observed is that the young trees are coming up everywhere in great quantities. Grass and various herbaceous plants are abundant and thick.

To make the forest reserve more effective, power should be given to the forest supervisor to open roads and trails. In the Uintah forest reserve there can be no doubt that the most important factor in diminishing the water supply is injudicious grazing. 
Much forage of good value occurs in all of these reserves and from an impartial standpoint I am inclined to the opinion this should be used but regulated in such a manner that forest trees will not suffer. To do this will require good officials, who will harmonize the various conflicting interests. I would respectfully urge the sentiments expressed by Mr. Pinchot and Dr. Roth in their several papers. 


\section{GRAZING ONPUBLICLANDS OFCANADA}

(Impromptu Address)

\section{BY \\ R. H. CAMPBELL}

Secretary, Canadian Forestry Association

I DO not respond to the call for Western men, but am very glad that the discussion has been brought back again to Western conditions, because I am connected with the Department of the Interior of Canada, which has the management of the Western lands and deals with the problems which have been specially brought before the Congress this afternoon, and I thought a statement of the method that has been adopted by us in dealing with the Western grazing interest might perhaps be of some interest to the Congress. The problem has not become an acute one with us in connection with the forest reservations. The grazing has not injured them seriously, and we have not developed the management of the forest reserves to such an extent that we have given much attention to that subject. Another reason why the grazing in the forest reserves has not been a very pressing subject is the fact that there are no sheep grazed in close proximity to the reserves or within them, and as the chief objection has been made to the grazing of sheep in the reserves on your side of the boundary, I think it is from that the problem has largely arisen. In the lands outside of the reserves we have been following for a number of years a leasing system. We have not laid down the principle, which apparently has been laid down in your administration, that the range is free to any man who wishes to make use of it; in fact, we lay down the principle, in the first place, that no person has the right to make use of the public land 
for grazing purposes without special permission from the Minister of the Interior, and then we go on and define the rules by which he may be allowed to make use of that land for grazing. The regulation that has been followed for a number of years is that leases for a period of twenty-one years may be granted for an area not to exceed I00,000 acres. The rental asked for this lease is two cents per acre. A number of leases have been taken up under this system which have brought in a fair amount of revenue to the Government. Recently the large influx into and settlement of our West has raised the question of the management of the grazing lands to an important position and made it a more acute one. When grazing leases were first adopted a feeling arose between those holding leases and some of the settlers who wished to go in on these leaseholds. The Government then decided, in consequence of the agitation that so arose, to cancel these leaseholds, allowing the holders to purchase one-tenth of the area and thereafter granted leases only subject to a homestead entry. That policy was followed for some time, and then later a number of leases were granted without the provision that homestead entry should be granted within them. Considerable objection was made, and it was finally decided to suspend further action until the matter could be given full consideration. It has been under consideration for some time past, and although I am not in a position yet to say fully what will be finally decided, I think that the decision will be that we will stick to the leasing system. We have found it to work out with a fair degree of satisfaction, and I think that the fact of giving the leaseholder a proprietary right to a certain extent will make him careful to see that the land of which he has control is not overgrazed and is kept in proper condition for all the time that it is held under lease by him. 


\section{PART V}

RAILROADS IN RELATION TO THE FOREST 



\title{
WHAT INFORMATION IS MOST URG- ENTLY NEEDED BY RAILROADS RE- GARDING TIMBER RESOURCES
}

\author{
BY \\ GENERAL CHARLES F. MANDERSON
}

General Solicitor, Chtcago, Burlington and Quincy Railroad Company

A SHORT time before the year 1860 there crossed the most progressive development and most intelligent progress, to make a home in the then Territory of Nebraska, a young man, who joined to physical strength and virile force a keen appreciation of the needs of the future and a determination of purpose only equalled by the intelligence which guided that purpose, and the abounding faith that led to the desired result. Settling upon broad acres of virgin soil, he found himself in a treeless region, on the eastern edge of what the geographers of the day were pleased to call the Great American Desert. He was one of the leaders of that hardy band of men by whose aggressive power that desert land, the range of the wild buffalo and the hunting ground of the wilder Indian, was to be developed into an agricultural garden, whose products in a single year, in less than fifty years of development, were to very nearly equal in value the annual output of all the gold and silver producing mines of the world. For had this pioneer lived to 1904 he would have seen from the yield of the fields of vast extent of corn and small grain, from the domestic animals ready for the world's market, a product valued at $\$ 500,000,000$, or over three times the value of all the gold and silver 
produced that year in the United States.

The youth who thus settled, less than half a century ago, near the banks of the turbid and oft times turbulent Missouri, looked about him with sorrowful and, I fear, regretful gaze. On all that broad expanse of undulation no tree to gladden the sight, no shade to offer its restful protection to contemplative man or reminating beast. He called to mind the groves of his native state; he thought of the spreading oaks, the leafy maples, and the stately pines of Michigan, and probably from the longing homesickness there came the inspiration that ripened into the motto of his life: "Plant trees." From that inspiring thought came a transformation delightful to contemplate. Standing now on the eminence where he built his home, on every side are to be seen the sylvan evidences of his industry and foresight. Lofty trees, many of them true monarchs of the forest, wave their graceful tops as the wind makes music in the branches, singing ever a grateful requiem to the builder of Arbor Lodge. The example he set has not been lost. Groves innumerable now dot the landscape, once so bare. Countless millions of trees have been planted as a result of his persistent inculcation of the benefits of tree-planting, and in every State and Territory of the United States, except Delaware and the Indian Territory, by legislative enactment or executive proclamation one day in each year is set apart as a legal holiday in which the people are encouraged to plant trees. It is a monument to his memory more enduring than marble, more lasting than brass.

Need I give the name of the founder of Arbor Day to you-lovers of trees that you are? The names of J. Sterling Morton and James Wilson are indissolubly linked together in the annals of forest development. May their tribes increase! 
The President is quoted as saying that the forest question is the most vital internal problem in the United States. It is truly so, and we are here assembled to give increased vitality to the movement to substitute saving for losing, preservation for assassination, creation for destruction, birth for death. We are here to say to the servants of the people that as compared with the reforming or the deforming of the tariff and its schedules, the extinction or the encouragement of trade combinations, the regulation or the demoralization of interstate transportation-all questions of importance, we admit-the problem of how we shall conserve the timber production of the country is the paramount issue. By its conservation we are preserved; by its destruction we perish. The suggestions as to the best methods of preserving what we have and adding to our store are for you who are experts, and not for me, a mere tyro, to give.

My duty at the moment is to show briefly the needs of the railroads as to timber resources. I might spend time in showing the relation that railroad transportation bears to every industry, and that under the methods of modern civilization not one could be successfully maintained without it; but this would insult your intelligence. The needs of railroads can, however, very profitably be called to your attention. There are in the United States 206,885.99 miles of main tracks, $79,376.03$ miles of second tracks and sidings, being a total mileage of $286,262.02$. The vast number of trees needed to be felled to maintain this tremendous mileage is so enormous as to stagger belief and exhaust a reasonable amount of figures. The timber goes mainly into ties, bridges, station houses, road crossings, rolling stock, platforms, furniture, and also into many minor uses. Wherever used there comes to it depre- 
ciation and decay, demanding renewal and replacement.

Let us consider the matter of ties alone, for that will serve as a fair parallel to all other uses for railroad purposes. The average number of ties to the mile of tracks is 3,000 ; so that $858,786,000$ ties have gone into the construction of the tracks. The probable average life of an oak tie is ten years. Pine ties naturally last from four to six years, and when burnetized, creosoted or otherwise treated their average life is probably extended to ten years. It will, therefore, be seen that ro per cent of the ties now in track must be renewed annually, making a yearly demand for replacement of nearly $90,000,000$ and in a decade $900,000,000$. The average price of oak ties is 55 cents, and of pine ties $3^{8}$ cents each. Treating for prolongation of life adds Io cents to the cost of each tie. The average cost of all ties now going into the trackage of the railroads of the United States is 50 cents apiece, making an annual expenditure of $\$ 45,000,000$, and $\$ 450,000,000$ every ten years; and this calculation of cost does not include the labor of placing the ties in the track or the expense of local transportation. Nor does it take into account the gradual but inevitable increase in price as the supply lessens, the demand incident to the building of the new lines of road absolutely demanded by the ever-advancing commerce of the country, both intra and interstate, and the necessary supply of street car lines, both horse and electric; elevated railways, subways, and mine tracks. The demands of these corporations are enormous, and constantly increasing. Add to these requirements the many others caused by the uses heretofore briefly referred to and some conception can be had of how capacious is the maw of the great transportation lines of the republic, upon whose successful and steady maintenance all industries 
depend. It may be better that I should state that they are interdependent, for without these industries railroads could not thrive, and without the railroads the industries could not survive, and to maintain both industries and railroads the timber and lumber product of the forests is the prime factor and absolute necessity.

This much for the needs. What of the supply for the needs, the satisfaction of these wants? It is not only the preservation by judicious forestry and intelligent lumbering of the store we have, but the planting and husbanding, wherever trees can be induced to grow, of new forests. To this end there must be the arousing of public sentiment, so that in every state and in the nation there shall be taught the lesson that will lead to legislation encouraging timber growth. The labor must not only be one of love, but one of duty. We should rejoice in the fact that in this movement, fraught with so much of good to the republic, sentimentalism joins hands with commercialism.

"There is a pleasure in the pathless woods," but there is profit as well. It is difficult, $I \mathrm{know}$, to determine to sow where we cannot reap. The man who plants trees works not for himself but for posterity; but we should remember that with almost criminal recklessness and censurable disregard of the rights of the future we have destroyed that which a decent regard for the race should have prompted us to preserve for those who shall come after us, and certainly from that standpoint we owe much to posterity.

The legislation of Congress from I8I7, when the first timber preservative act was passed to save live oak and red cedar for naval purposes, to this time has not been marked by great wisdom. It is to be hoped that there may speedily come a repeal of the Timber and 
Stone Act, as recommended by the American Forestry Association, and I submit that in view of the evident necessities of the railroads of the west, building pioneer lines, that form the vanguard of civilization, that under the judicious cutting of timber on government lands, by carrying out the natural rule of the survival of the fittest, the requirement that the resulting product cannot be exported from the district or state wherein it is cut may well be repealed and be used wherever upon such railroads the necessity for its use is apparent. The popular demand is that the rates of freight, so greatly reduced during the past few years, should receive still further reduction. This can be obtained only by economy in construction and maintenance, and every measure that tends to that result should receive encouragement.

We of the West are watching with concern the interesting experiment of that admirable Chief Forester Pinchot in the planting of pine cones and young pines in our sandhill country. If this otherwise useless land can be made to grow merchantable pine it will have justified its hitherto useless existence.

The experiments of the Government, of the railroads, and of private parties in prolonging the life of timber are of great importance. The saving of the forests, if the life of a tie can be prolonged, will be very great, for as yet no substitute has been devised for wood ties that is either economical or desirable. They maintain the alignment of the railroad, so essential to safety, better than any metal substitute and give an elasticity to the roadbed most important for the preservation and maintenance of the rolling stock. With metal ties, or a stone base, the rails would be speedily injured, and the heavy Mogul engines used to-day, drawing the heavy trains of large cars needed for the traffic, would 
pound themselves quickly into decrepitude and uselessness. The change in the character of rolling stock is worthy of consideration. Engines have increased in weight from twenty-five to one hundred and ten tons; freight cars of twenty-eight feet length, with twenty thousand pounds carrying capacity, have increased to forty feet of length with one hundred thousand pounds capacity.

But why prolong the wondrous tale of development and progress? We have reached the point from which we must yet advance or retrograde. We cannot stand still. We are considering the main element of that hoped-for progress. Let us take lessons from the nations across the great water. From Germany, Austria, Hungary, and Switzerland let us learn how to establish schools of forestry, how to eliminate waste and mismanagement, and to subrogate private rights to public necessity. From Bohemia let us learn how to furnish fuel and building material for a dense population and yet retain the area of the primeval forests and add thereto. Let us learn wherever there is a teacher, for there is no lesson more essential to our welfare. Let us adopt the motto of the pioneer Morton and under state and federal guidance and direction "plant trees." 


\title{
WORK OF THE PENNSYLVANIA RAIL- ROAD IN PLANTING TIMBER FOR CROSS TIES
}

\author{
BY \\ JOSEPH T. RICHARDS
}

,Chief Engineer, Maintenance of Way, Pennsylvania Railroad system.

$\mathrm{I}^{\mathrm{T}}$ has been largely through the instrumentality of the American Forestry Association that the railroad companies of the United States have been brought to realize the gravity of the situation with reference to a future timber supply, from which is to be furnished the large quantity consumed by the railroads in the production of cross ties. The rapid spoliation of our forests-the sole source of our supply-and the imminence of its entire depletion, are only too strongly presented to us by those familiar with the subject. It would take more time than I have at my disposal to obtain statistics to cover the entire field of timber consumption in the United States, or to make any reliable computation of the amount of timber still standing, and available for future supply; but a few figures illustrative of the general character may be of interest as an introduction to what more particularly concerns the Pennsylvania Railroad System.

During the past year the Pennsylvania Railroad Company has had the subject considered and a report made by a committee of our transportation association, and I will draw from this report some data for my remarks to-day. The number of cross ties in use on the railroads of the United States is estimated to be about $620,000,000$; the number used annually for repairs, and for extensions of track, is estimated to be 
from $90,000,000$ to $I 10,000,000$, requiring, we may say, the entire product of 200,000 acres of woodland annually.

Each year the timber from which these are manufactured is farther from the base of transportation, and many of the former sources of supply have already been entirely exhausted. Our Pennsylvania railroads now look chiefly to inland Virginia, West Virginia, and Kentucky for their white oak ties; and the longleaf yellow pine of the southern states will soon disappear. Probably another decade may nearly close these sources of supply.

The annual consumption of ties on the Pennsylvania Railroad System east of Pittsburg and Erie, for repairs only, is about $3,000,000$, this being about the average quantity used every year for repairs in the past ten years. To this should be added, say, one-half million used annually in new work. It is evident, therefore, that at the present rate of consumption the available supply of the present timbers used, especially white oak and yellow pine, will be exhausted to a serious degree before many years, and the time is now ripe for the railroads to consider the question of what course they are to pursue in the future.

Under these conditions there are obviously two courses : First, the reduction of the amount consumed, which can be done by the substitution of other material for wood, and by the use of preservative methods for prolonging the life of the ties, and which by increasing its durability will diminish the annual requirements for renewals; and, second, by the adoption of forestry methods having for their purpose the proper care and management of the forests still remaining, and the cultivation of new tree plantations.

It is to the latter to which I will chiefly confine my 
remarks in connection with this all-important subject. The question of forest preservation and perpetuation is beginning to receive attention in this country through the several State Bureaus of Forestry which have been established, and attention is given to forest preservation by these, as well as by the National Government. The National Government has established a Bureau of Forestry, which is doing valuable work in the dissemination of useful information and by creating a popular sentiment in favor of the subject, and its coöperation with railroad companies and lumber industries in the introduction of proper methods for the preservation and perpetuation of the timber supply of the country.

The necessity or advisability of a railroad taking an active part in forestry operations, looking especially towards its future supply of cross ties for its own use, is comparatively a new idea. As long as twenty-four or twenty-five years ago, on the Pennsylvania lines west of Pittsburg, attention was already given to the subject, and a number of catalpa trees were planted along the right-of-way of one of its lines; but the results obtained were unsatisfactory. More recently, the cultivation of the yellow locust as a tie timber has been brought to our attention, and the cultivation of this tree to a limited extent for the purposes named has been undertaken.

Within the past two years we have begun the planting of yellow locust trees on an extensive scale on property owned by the company. The trees thus planted are seedlings two or three years old, and cost, including labor of planting, about eight cents each. Generally speaking, these are planted ten feet apart, thus averaging about 400 to the acre; although in the fall of 1904 we planted 54,87 I trees six feet apart and 88,127 trees eight feet apart. 


\section{AMERICaN Forest Congress}

The total quantity planted to date is as follows:

Fall of Igo2 at

Totals.

Newton Hamilton, .......... 13,610 13,610

Fall of 1903 at

Conewago, .............. 43,364 43,364 Spring of 1904 at

Conewago, .............25,096

Pomeroy, . ............. 20,280

West of Atglen, .......... I6,537

Atglen, ............. 8, 108

Fall of I904 at

70,021

Juniata Bridge, . ......... 20,730

Newport, . .............29,505

Vintage, ................ 50,300

Atglen \& Susquehanna Branch,

P. R. R., ........... 53,000

I 53,535

Total

280,530

All of the above places are in the State of Pennsylvania. During the coming year we expect to plant about 800,000 trees additional, likely 200,000 in the spring and 600,000 in the fall. The land on which we planted these trees, except a tract of fourteen acres at Newton Hamilton, which was purchased for this particular purpose, are lands which the company has owned for some time and which were acquired in connection with old or new lines.

There is probably no other timber which combines so well the qualities of durability and hardness as does the yellow locust. Evidences of its longevity in use as tie timber are frequent on our road. The resistance of locust timber to cutting under the rail is said to exceed that of white oak, and it has been demonstrated 
upon our main lines that it is not so much the decay of the timber as it is the cutting in by the rail which wears out or decreases the life of the tie. The average life of a white oak tie is about ten years; we expect to get additional life out of a locust. The main attention which this class of timber seems to require during growth is that of pruning the lower branches of the young trees, ploughing and harrowing the ground in which they are planted, and keeping the weeds down as far as possible.

While it is not likely that the Pennsylvania Railroad Company will at any time undertake to plant a sufficient number of trees from which to secure its entire supply of cross ties, we feel that the experiment made by it of raising its own tie timber will have a tendency to stimulate outside parties, who are small owners of property, to cultivate this class of timber, and in this way assist the railroad company in the vicinity in which they are located by furnishing cross ties at some future time.

In order to supply our entire needs for the year, namely, 3,000,000 for repairs and half a million for new work, and adding thereto ro per cent for the immediate future increase, making the total annual requirements $3,850,000$ ties, we figure that, three ties to a tree, would require about $1,300,000$ trees each year to produce the probable number of ties needed. To produce the necessary number of trees of the proper size for tie-cutting each year, in order to harvest the $3,850,000$ ties (figuring that it will require thirty years for a yellow locust tree to mature), would require a continuous growth of $39,000,000$ trees, I,300,000 to be planted each year, which, if planted ten feet apart, or about 400 trees to the acre, would entail the continuous use of 97,500 acres, or 152 square miles of ground, for the purpose. 


\section{IS IT PRACTICABLE FOR RAILROADS TO HOLD FOREST LANDS FOR FUTURE SUPPLIES OF TIMBER?}

\section{BY \\ L. E. JOHNSON}

President, The Norfolk and Western Rallway

I CAN but express my appreciation at being requested to present a subject for the consideration of this Forest Congress, and being asked to answer the question: "Is It Practicable for Railroads to Hold Forest Lands for Future Supplies of Timber?"

We find that it is one that can be discussed from the standpoint of railroads, and while the question from this standpoint is an important one, is it not a question, by reason of its relation to the public at large, in every industry and occupation, and in the individual and domestic needs of every citizen, from the standpoint of the public at large?

The preservation of forests is not only necessary for supplying railroads with cross ties, with timber for its trestles and cars, but is necessary to maintain the supply of wood for the various manufacturing, building and domestic purposes of the public. It is equally, if not more, necessary to maintain and protect the water supply in streams, the demands on which are increasing by reason of an increasing population, and by reason of the rapidly multiplying requirements for power in its many forms. And it is equally necessary to preserve our forests, to prevent floods, and to prevent droughts.

All this is well put in the definition of what forestry 
is by one of the gentlemen connected with the Bureau of Forestry, in his article in a late Encyclopedia. I refer to the article by Mr. Gifford Pinchot, "Forestry in the United States," Encyclopedia American, Vol. VII, where he defines the subject as covering this broad ground:

"Forestry is the art of using the forests continuously to meet the needs of men. In the United States forestry has to do principally with the supply of wood for various purposes, with the maintenance of water-flow in streams, with the prevention of floods and with the supply of foliage for grazing animals within the forests. Nowhere else are forest problems of more vital importance to the welfare of the people than here, and in no other country of civilization has so little progress been made in their solution. This condition follows naturally from the vast area of the United States, its comparatively sparse population per square mile, and from the nature, location, and extent of the forests themselves."

Referring to the same authority, "Some Uses of Wood:" "The yearly product of wood in the United States is about $35,000,000,000$ feet. In 1900 the lumber industry employed two hundred and eightythree thousand two hundred and sixty $(283,260)$ wage earners, to whom it paid one hundred and four million six hundred and forty thousand five hundred and ninety-one dollars $(\$ 104,640,591)$. The perpetuation of this industry is of vital concern to all the people. Its ramifications are as wide as the industrial life of the nation, and its perpetuation is a most pressing concern of the forester. The use of wood for the maintenance of railroad tracks, for example, rises to about 120,000,000 ties a year, together with the vast amounts of bridge timber, piling, etc. Since the use 
of metal ties is believed to be impracticable by American railroad engineers, the maintenance of the supply of wood and ties is of vital importance to the railroads, and through them to the nation at large. In a similar way, the permanence and success of the mining industry is dependent upon cheap and accessible supplies of timber. In most portions of the West such supplies can be expected only from the national forest reserves. In the creation of the reserves, therefore, the special needs of the mining and other industries have been kept carefully, and it is also believed successfully, in mind."

Without regard, therefore, for the necessity of preserving our forests for the other purposes equally important to the country, as the means of supply of wood for industrial and domestic purposes, it would appear that railroads, although they are consumers of an enormous amount of wood, their uses of wood form but a fraction-relatively a small fraction-of the yearly consumption of wood. I will, therefore, undertake to discuss some of the details from my personal knowledge of a railroad extending from tidewater on the east to points in Ohio to the northwest, and through Virginia to the southwest, embracing lines into Maryland and North Carolina, in addition to other lateral lines within reasonable limits of timber for its entire distance.

Originally the country passed through by the railroad to which I refer, was well timbered. The first extensive depletion of timber land was on the first hundred miles adjacent to the seaboard, where the original timber was cypress and Virginia or loblolly pine. Up to the year 1888 this road used a great many cypress ties, but such timber is no longer procurable. The second growth of Virginia loblolly pine in this same 
district is very knotty, and, further, it is not suitable for cross ties until it be treated to improve its lasting qualities. All the balance of the road is in territory where both white oak and chestnut oak is indigenous, and up to quite recently all the cross ties that have been needed have been obtained within moderate hauling distance from the railroad line.

The class of ties that have been obtained to date have been of a high grade. After a time of careful watching extending over a period of twenty years, it has been found that the life of these white oak and chestnut oak ties has averaged about nine years.

This railroad is, therefore, a road presenting problems that are common to many other roads, and the above question can be, in part, answered by using it as a typical case.

At the present time the main line is 1,543 miles; branches, 226; second track, I50; sidings, 652; total mileage, 2,57I. The average requirements in oak ties per year for renewals are three-hundred and ten (3ro) per mile, aggregating in round numbers eight hundred thousand $(800,000)$ per year. At prevailing prices eight hundred thousand $(800,000)$ ties cost per annum about three hundred and fifteen thousand dollars $(\$ 3$ I 5,000$)$, which is shown to be about fifteen per cent. (I5) over the cost of a like number ten years ago. This total figure is far below what some railroads less fortunately situated must pay for a like number.

Both chestnut and oak timber is of such slow growth that we cannot for a moment consider the attempt to cultivate it for tie timber. While oak will naturally grow for the whole length of this and other railroads, largely by self-sowing, if the soil is left idle, we cannot count on that method to secure timber for many years to come in view of the great expansion in lumber industries adjacent to railroads. 
According to our.information, the only tree that has a comparatively rapid growth and which will, according to the best evidence obtainable, furnish a first-class cross tie of long life, is the catalpa. It is claimed that this tree will, in twenty years, make ties that will last fifteen years in track. However, the timber is soft as compared with oak, and will, of necessity, require tie-plates.

Assuming the life of a catalpa cross tie as being fifteen years, the requirements per mile per year for renewals would be about 200 , making the requirements for the present mileage of the road under consideration, allowing for emergencies, about six hundred thousand $(600,000)$ catalpa ties per annum.

Let us now consider the question of cultivating catalpa trees for cross ties. We find that one acre of standing catalpa trees will produce, when twenty years of age, eight hundred and fifty (850) cross ties. Therefore, in order to secure six hundred thousand $(600, \infty 00)$ cross ties per annum, about seven hundred (700) acres of land bearing catalpa trees twenty years old will be required each year; hence, there should be planted every year, for the requirements of the railroad, having a mileage of two-thousand five hundred and seventyone mile $(2,57 \mathrm{I})$, seven hundred ( 700$)$ acres of trees, and this planting must be continued for a period of twenty years before any cross ties can be secured. As we are to plant seven hundred (700) acres each year during the twenty years, we must plant a total of fourteen thousand ( 14,000$)$ acres, or, allowing for some waste land, about fifteen thousand (15,000) acres must be secured. Such a large body of land as this cannot be obtained unless it be in districts where there are at present comparatively large bodies of waste or cheap land. There is no point on this railroad where 
such a tract of land can possibly be secured unless it be near tidewater.

We, therefore, estimate the cost of establishing such a timber reservation on the line of this road would be as follows:

I5,000 acres of land at $\$ 10 \ldots \ldots \ldots \$ 150,000$

Interest on this for I9 years up to

cutting time at 5 per cent.... 142,500

Total cost for land. ..... $\overline{\$ 292,500}$

Annual expenditure for nineteen years before any growth is obtained suitable for ties:

Taxes ...................... at $\$ 15 \ldots \ldots \ldots \ldots \ldots \ldots$ ro, 500

470 trees delivered at $\$$ Io per M... 4,700

Planting 700 acres at $\$ 5$ per acre.. $\quad 3,500$

Superintendence, \&c., .......... $\quad 1,800$

Total annual cost ..... $\$$

This annual charge of $\$ 22,000$ for nineteen years aggregates .... $\$ 418,000$

Interest on this amount for an average term of $9 \mathrm{~T} / 2$ years at 5 per

cent. ................ 198,550

Cost of land as above .......... I50,000

Interest on cost of land, 19 years,

as above, at 5 per cent....... $\quad \mathbf{1 4 2 , 5 0 0}$

Total investment up to zoth year $\$ 909,050$ 
Annual expenditure after the twentieth year and each year thereafter:

Interest on investment, $\$ 909,050$, at

5 per cent. ............ \$45,452

Taxes ................. 1,500

Reclearing, \&c., 700 acres at $\$ 5 \ldots \quad 3,500$

470,000 trees delivered, at $\$$ ro per M. $\quad 4,700$

Planting 700 trees at $\$ 5$ per acre... $\quad 3,500$

Superintendence, \&c. ......... $\quad 1,800$

Annual cost......... \$60,452

Cutting and delivering 600,000 catalpa ties f. o. b. cars at

20c. ............... \$120,000.00

Annual cost of ties after 20 years. $180,452.50$

It should be noted that twenty years hence, at the present rate of increase in the cost of oak ties, the cross ties necessary for the railroad in question will cost an aggregate of four hundred thousand dollars $(\$ 400,000)$ in the twentieth year. The saving through this transaction would, therefore, be, per annum, after the twentieth year, four hundred thousand dollars $(\$ 400,000)$ less one hundred and eighty thousand four hundred and fifty-two dollars and fifty cents ( $\$ 180$,452.50), equal to two hundred and nineteen thousand five hundred and forty-seven dollars and fifty cents $(\$ 219,547 \cdot 50)$.

The above great difference in figures would indicate an enormous saving possible by railroad companies undertaking to hold large areas of land, either directly or indirectly, to cultivate tie timber alone. And while it was possible a number of years ago for railroad companies to hold large tracts of land, laws do not 
give them the right to condemn lands for cultivating timber. Therefore, unless railroad companies have a right to condemn land for such purposes, such large tracts as are required cannot be obtained at prices such as warrant the above estimate. It is evident that some modification of the existing laws would be necessary in order to render it practicable for railroads to hold large tracts of land for future supplies of timber.

Further, the investment of one hundred and fifty thousand dollars $(\$ 150,00)$ in land, and an added investment each year for a period of nineteen years, until a total of nine hundred thousand dollars $(\$ 900,000)$ is reached, will require a special arrangement on the part of railroad companies in order to look forward to the holding of various lands for such a long period of time. It might be claimed that land could be bought only seven hundred (700) acres at a time. If this plan should be followed, the prices would be advanced by the very improvements undertaken by the railroad company. The only practicable plan of procedure would be to purchase at the beginning of the undertaking all the land required by a railroad company.

Right here let me repeat that the above calculations are based upon estimates made for a certain railroad; however, they may form a basis for like calculations on any railroad in any section of our country, taking into consideration the environments and conditions. In the above figures no account has been taken of the danger and loss from fires, but the item of. superintendence is included; and further, an item of profit in the way of securing posts and other timber has not been credited simply with a view of making an estimate that would be safe to cover ordinary emergencies.

I have in these estimates only considered one thing, 
namely: ties, for the reason that the use of timber for other purposes in railroad work is rapidly being substituted by steel, brick, stone, and concrete. The above presentation apparently shows a saving to the railroad company to be great and advantageous. On the other hand, the time required to secure the growth, changes in railroad methods, increase in length of railroad through construction, or decrease through sales, and the possible future improvement in the form of construction of standard track, throws at once grave doubts upon the advisability of any such plan. These doubts lead me to the conclusion that it is not practicable for railroads to hold forest lands for a future supply of timber, but that it is a question of such magnitude that it can best be handled by the investment of private capital, or under the Bureau of Forestry of the United States Government, in connection with appropriate legislation by the State Governments.

While railroads can and should coöperate heartily in every way to preserve our forests from waste and destruction, I am forced to the conclusion that no practical results can be obtained without legislation putting the entire subject with Government control. The subject is one of such magnitude, affecting directly and indirectly the needs of every citizen and every community of our country, that any scheme that may be adopted must be comprehensive enough to conserve all interests and accomplish definite results.

Legislation is required to enable forests lands to be acquired or reserved at the headwaters of streams and in other suitable locations.

Laws must be enacted to require the citizens to plant and maintain timber under appropriate circumstances:

Laws must be enacted and enforced to prevent fires and the unnecessary destruction of trees. 
Legislation, too, should be provided to restrict the use of timber as much as possible for the use of our own citizens.

The waste of timber should be prevented to the extent practicable by proper laws.

And all such laws should, in order to be effective, be administered by officials invested with the authority of law.

It would further appear that the large commercial demands consequent upon the great growth of our country, together with the immense quantities of the very best grades of timber which are exported, constitute a greater menace to our forests than the consumption by railway companies.

In this connection, I would like to mention a large quantity of chestnut oak which is felled every spring to procure bark for tanning purposes, much of which is allowed to lie in the woods and rot, although railroad companies, and I presume others, would be glad to get the material, sawed into merchantable lumber, or have it made into ties. This constitutes a great and wanton waste. We think that we are fully able to verify this statement from the frequency with which we have to decline ties made from timber which has been felled in years other than the current year.

In considering this timber question in any of its aspects, we recognize that the study of it, together with a great many other questions of like import, marks a new era in the affairs of this country.

Heretofore the American people have been wasteful, and extravagant to an alarming degree, of every product and everything which have been generally used for the necessities and comfort of the people. Nature has been prodigal in distributing natural resources through our land, and for years we have been simply 
drawing upon these accumulated resources without stint and without regard for the future. Our population now is becoming so congested and the demands upon the resources of the country are so great that it is necessary for intelligent and conservative people to study the forestry question and other like propositions, to the end that the natural wealth of the country shall not be wasted to such an extent that the conditions of living by our people shall become more difficult. I know of no single question that is entitled to more consideration, by persons influencing large corporations, than the timber and forestry question.

Such meetings as the one now being held in Washington will necessarily result in great good in that they will bring to the attention of large numbers of people, and especially people of character and influence, conditions which otherwise might be overlooked or be passed unnoticed. 


\section{RESULTS IN THE PRESERVATIVE TREATMENT OF RAILROAD TIM- BERS TO PROLONG DURABILITY}

\section{BY \\ DR. HERMANN VON SCHRENK}

Bureau of Plent Industry

I $\mathrm{N}$ a discussion of the railroads in their relation to the forest there is no topic which is at this day of such importance as timber preservation. We have heard that there is probably no one interest in this country to-day which can compare with the railroad as a timber consumer, and certainly there is none which has a more direct and vital interest in seeing that a definite and constant supply of all kinds of timber is assured in the future. It is my privilege to point out in a few words what bearing the chemical preservation of wood, with its attendant features, has upon the general problem of future supply, and to what extent the results obtained therefrom may lead to a more economical utilization of forest supplies in general.

In dealing with this subject I propose to consider briefly the following points:

r. Why railroads in their capacity as consumers of timber are interested in preservation.

2. Why railroads are interested in preservation from a traffic standpoint.

3. Why railroads are interested in timber preservation from the standpoint of economy.

4. What preservation means.

5. What results have been obtained.

6. Some general conclusions. 
Up to within recent times most of the tie and construction timbers used by the railroads were timbers like the white oak and longleaf yellow pine. These were used because they combined great durability with strength and good wearing qualities. They were abundant along the lines of the roads and were obtainable in large quantities and at a comparatively low cost. A purchasing agent had no difficulty, not more than ten years ago, in getting any number of first-class white oak ties in the middle or central states at from 35 to 60 cents. While the prices for such timbers are not yet excessive owing to local supplies, it is, nevertheless, becoming increasingly difficult to obtain large regular supplies of such timbers, and with an ever-increasing demand, the question has been asked for several years, and with increasing anxiety, where the tie supply is to come from in the future. It may not be without interest to state here that, according to a recent estimate made, about II8,000,000 ties were used for renewal purposes during Ig04.

As a result of the uncertainty in getting a sufficient number of ties which could be used in the natural condition, many roads turned toward the so-called inferior woods, like red and water oaks, beech, gum, the softer pines, hemlock, etc. None of these woods can be used without preservation, because they decay with great rapidity when in contact with the ground. It is not yet fully realized that when thoroughly treated that a red oak or beech tie becomes the equal, if not the superior, of an untreated white oak tie, as far as resistance to decay is concerned. The use of such woods as red oak, beech, loblolly pine, etc., if generally adopted, would bring into the market a large body of timber which would insure a constant supply for many years to come. It is a fortunate circumstance that these 
so-called inferior woods, because of their greater porosity, can be treated with chemicals so as to preserve them very effectively.

The use of these woods, which is made possible by preservation, will not only open up a supply now standing in the forests, but it will also make possible the investment in lands producing such timbers. Many of these grow with great rapidity, at least sufficiently so as to make the possibilities of second and third crops a realizable possibility. Some day we may duplicate the conditions now prevailing in eastern France, where the preserved beech ties last until another crop of beech ties furnishes a new supply.

Preservation will therefore be an almost indispensable factor in any consideration of future supply, and when one considers the good results obtained, its importance will be fully realized.

The use of shortlived woods for tie and construction purposes when chemically preserved will have a wholesome effect on the utilization of the higher grade longlived timbers. The writer has repeatedly pointed out that the full value of a piece of white oak is not realized in these times when it is used in the form of a tie. White oak is coming to be more and more valuable in the form of lumber and for construction purposes, for car building, in the cooperage trade, etc. A railroad using white oak for ties at a valuation less than one-half of what it would be as car sills or cooperage stock, is cutting off industries which it should foster along its lines. This is especially true when the road could be using less valuable woods for what must be considered as inferior service, such as ties or piling. These woods when treated are just as serviceable and oftentimes better than the more valuable wood. This is a point worthy of serious study from the traffic standpoint. 
Another point which may be alluded to here is the influence which the use of less valuable woods, always after preservation, has on local business and feeling. The less valuable woods are generally distributed along most of the railway lines, and should they come to be generally used, every owner of woodlands would find a local market for one class of his farm product which he now has but little use for. This is not only true for ties, but for other classes of material. Take fence posts as an example. Many roads now use cedar, shipped long distances from off their lines. If birch, sycamore, maple, red oak, and saplings of other trees, which grow on every farm, were generally used, it would stimulate local interest, encourage home industries, as it were, and at the same time serve to give a large and comparatively cheap supply. That such saplings can be easily and cheaply treated (at a cost of 5 to 6 cents per post) has recently been successfully demonstrated.

While the foregoing points are doubtless worthy of consideration, it is, nevertheless, true that the foremost and immediate interest in timber preservation is one which deals with the more economical handling of the timber problem. Timber preservation would not mean anything if it could not be shown that in the long run it is cheaper to use shortlived woods when preserved than unpreserved longlived woods.

Without going into details at this point, it may be stated that there is probably no one to-day who does not believe that timber preservation in one form or another pays. The extent to which preservation will pay will depend upon several factors, such as the first cost of the wood, the cost of renewal, the cost of the treatment. In a recent discussion of this subject it was pointed out that the following table of annual 
charges might be taken for various kinds of untreated and treated timbers.

TABLE SHOWING ANNUAL, CHARGES.

Timber and

Treatment.
Length of Original Cost of Annual Service. Cost. Treatm't. Charge.

White oak, untreated..... ro yrs. $\$ 0.85$.... \$0.12I Red oak or loblolly pine, $\begin{array}{lllll}\text { untreated............... } 5 \text { yrs. } \quad .40 \quad \ldots . & .124\end{array}$

Red oak or loblolly pine, with zinc chloride treatment................ 10 yrs. $.40 \quad \$ 0.16 \quad .085$

Red oak or loblolly pine, with zinc creosote treatment................ I6 yrs.

Red oak or loblolly pine,

with creosote treatment.. 20 yrs.

.40

.25

.065

with creosote treatment.. 20 yrs.

.40

.45

.069

The conclusion to be drawn from such a table is that the treated timber in every case is cheaper in the long run than the untreated timber; furthermore, that the better treatments, although more expensive at first, are very much cheaper in the long run. One ought to add that the treatments given above were selected from a long list, as representing extremes and averages of cost.

Having reached the conclusion that timber preservation is worth considering; in other words, that it makes possible the utilization of timbers not generally used, and that it pays, one may consider somewhat more in detail 'some of the problems connected with preservation. One cannot dwell too frequently upon the sentence that timber preservation is not merely an injection of salts or chemicals into wood. I. have stated elsewhere that it involves not only the successful injection of chemicals, with all that that implies, but also 
keeping them in the wood, and after the wood has been rendered more or less decay or fire-proof, the protection against wear must be considered.

Successful preservation-that is, preservation which will pay-will depend upon:

I. The timber used.

2. The preserving method used.

3. How the preserving is done.

4. The man who supervises the preserving.

The selection of timber used should be governed by the available supply. The kind of wood used is after all probably the least important factor, because, when preserved, the indivuality of the wood becomes more or less insignificant. The longest-lived preserved timber, speaking with reference to decay alone, will be the one which will allow of the most perfect and even penetration of a preservative, and which at the same time will hold such a preservative. But we not only want long length of life, but also a timber which, with any given treatment, will bring an increased length of life which shall represent the greatest possible financial return on the original investment, made up of the first cost of the timber and the cost of the preservative process. It so happens that the open-grained porous woods which, when untreated, last but a comparatively short time, give high penetration and comparatively long increase in length of life; while the denser woods, which ordinarily are called longlived, give a poor penetration and a comparatively short increased length of life as a result of preservation. Recent tests with timber like beech and elm have shown an amazingly high absorption for zinc chloride, amounting to as much as .65 pounds of dry zinc chloride per cubic foot, using a $2 \mathrm{l} / 2$ per cent solution of zinc chloride.

It is, as has been stated, a fortunate fact that most 
of the shortlived woods conform to the requirements for long increase in length of life, just referred to, and that it will pay to use them.

Having decided upon the timber available which can be treated, the next problem is, how shall the timber be treated? In other words, what method shall be used? There are a host of processes, beginning with the metallic salts, like copper, zinc, mercury, etc., and ending with creosote or tar oil, either alone or in combination, for all of which certain merits are claimed, omitting, for the present, processes employing chemicals of unknown preservative value. I will not have the time to discuss this important question at any length and will restrict my remarks to a few general considerations which it seems to me should govern in the choice of a preserving process.

I regard the choice of a process entirely as one involving a certain risk in investment. One must start, of course, with the assumption that any one of half a dozen processes under consideration will actually preserve the wood for a shorter or longer time. This assumption is not unfair, when one is dealing with preservatives of such known value as zinc chloride, copper sulphate, mercuric chloride, creosote or tar oil, and possibly one or two others. Assuming, then, that these preserve wood, one naturally comes to the question of cost. This one may regard from two standpoints; the first one, which is the usual one in Europe, considers the annual charge; in other words, the saving which can be made in the long run when comparing an untreated with a treated piece of wood. A glance at the table which I presented a few moments ago will show that in the long run the creosoting process in some form is the cheapest, even if it costs more at the beginning; in other words, the annual 


\section{AMERICAN Forest CONGRESS}

charge on an untreated loblolly pine tie which has to be replaced every five years is \$o.I2, while for the creosoted tie it is only $\$ 0.06$.

Looking at the problem from the second standpoint, one considers the original investment, and not the annual charge. Taking the same case of loblolly pine, an untreated tie costs $\$ 0.40$. If this is treated with creosote one must add \$o.45 to this cost; in other words, a new tie and 5 cents more; while if one treats such a tie with zinc chloride one adds on only \$o.16, or about one-third the cost of a new tie.

For the European investor who deals with timbers of a high initial cost a comparison such as the one just mentioned does not occur. The French beech tie costing $\$ \mathrm{I}$ or more and lasting four years when untreated, will last 25 to 30 years when treated with creosote, at a cost of 75 cents or thereabouts. It is obviously the correct thing for these conditions to use the most expensive treatment. The number of ties treated is comparatively small, the economic conditions are more or less settled, and the investment of 75 cents per tie for treatment is not felt as a hardship.

When we turn to our condition in this country we have a different problem to face. While the spending of 45 cents for treatment of a 40-cent tie may give good results, it would be a poor investment, for the risk would be too great. After five or six years the tie sizes may be changed, and by that time only a small portion of the investment made in the treatment would be realized. An investment of 45 cents additional on a 40-cent tie lasting four years would furthermore mean the immediate expenditure of a very large sum of money, which would show no return until more than eight years had elapsed. This sort of investment is not profitable, although it doubtless will come at some future period. 
No treatment can be seriously considered which costs more than 25 to 30 cents. Wood is still cheap, and until the original cost of a tie goes to $\$ \mathrm{I}$ or thereabouts cheaper treatments must prevail. Of those advocated I would advise using the best; in other words, considering the investment from the first standpoint, that of annual charges. This would mean either a cheap creosote treatment, one using small amounts of oil with as good penetration as can be obtained, or a zinc creosote combination, both of which would cost 20 cents or thereabouts. The risk taken would be a small one because the preservatives have a known value and the original amount would not be a disproportionate one when compared with the cost of a new tie.

From this brief outline of the kind of preservative to be used, we may pass to some of the results which have been obtained from preservative treatment. While timber preservation has been practiced more or less in this country for many years, it has been carried on in such a way as to give few reliable data. The records which were kept during the early days are very unsatisfactory, and only very general conclusions can be drawn. In getting together the figures for the coming International Railway Congress, as to results obtained, we went carefully over all records kept by American railroads.

As a result of our study, we were able to report an average length of life obtained for hemlock ties laid in Iowa, treated with the Wellhouse process (zinc chloride, glue, and tannin), of Io.6 years; hemlock untreated lasts about four years. About the same length of service was obtained in the southwestern states with mountain pine treated with zinc chloride, glue, and tannin. These results are on the whole very satisfactory, for the length of life of these shortlived 
woods was more than doubled at a cost not quite one-half the original cost of a new tie.

Timbers treated with creosote show results in the United States similar to those obtained in European countries. Piling of longleaf yellow pine has been in service in bridges since 1869 and 1870 in several southern states, and a recent examination shows that the wood is still sound. There is no longer any necessity for doubting the value of creosote (or, as it should be more properly called, tar oil) as a wood preservative. Where a good quality is used, and with a sufficient quantity injected, an almost indefinite length of life can be obtained. The chief objection against its universal use has been the high cost of the oil and the small quantities available. There seems to be no good reason why more tar oil should not be produced in this country and at lower cost. It is encouraging to note the introduction of by-product coke ovens in which the available tar oils are being saved. More of those by-product ovens should be constructed, and if universally used in coke-burning regions there would no longer be any dearth of oil.

There are several new processes using creosate which are so conducted as to use small quantities of creosote, thereby reducing the cost of treatment and bringing the creosoting process within the range of consideration. In speaking of creosote, I cannot omit a word of caution as to the manner in which wood is frequently treated with tar oil. Creosoted wood has a bad reputation in many quarters, for it is said that the treatment with tar oil makes the wood weak, brittle, and brash. That such is frequently the case no one who has had occasion to examine any amount of creosoted timber can doubt. During the past summer we have been conducting an extensive series of tests at 
St. Louis to determine what influence treatment had on the strength of wood fibre. The effect of the usual preliminary steaming was investigated, and also the effect of injecting creosote in varying quantities without preliminary steaming. While it is as yet too early for final conclusions, I am glad to be able to state that we have determined very definitely that the injection of creosote into wood has about the same effect as injecting a similar amount of water; in other words, the creosote in and of itself in no way renders wood brittle and weak. We found that the brittleness or weakness was brought about by the steaming operation before the injection of the oil. Steaming at 20 pounds for about four hours did not affect the fibre materially, but when continued for a longer period the wood was weakened. After ten hours of steaming at 20 pounds pressure the wood decreased as much as 26 per cent in strength. The same was true when steamed at higher pressures.

These results clearly indicate that where the best results are to be obtained as little steaming as possible should be practiced in treating wood with creosote. This will probably hold for other preservatives as well.

A word should be said here concerning some of the problems dealing with abrasion of treated timbers. No process of preserving will pay if the preserved timber is rendered unfit by being worn out prematurely. The question of tie plates and rail fastenings should receive serious consideration in all discussions on preservation. It so happens that many of the shortlived woods are soft and easily worn. Preservation will protect them against decay, but not necessarily against wear. Recent trials with wooden tie plates have proven very encouraging. Some of these, made of cypress, have been in a main line track for eight months 
with very satisfactory results. This goes to show that there may be many ways and means for protecting the soft woods against wear.

The success of any preservative process will depend largely upon the care with which it is carried out. One must come more and more to the realization that preservation is a dendro-chemical industry, involving a technical knowledge of timber and of chemical processes, all stages of which should be carefully controlled. In dealing with timber one deals with one of the most variable classes of material, no two pieces of which are alike at any time, and knowledge and judgment are required to obtain the best results under these varying conditions. There are numerous preserving plants now in operation, but of these there is only one, so far as I am aware, where a trained chemist with a good laboratory watches every stage of the process. The wood-preserving industry, although it has been practiced in this country for many years, is still comparatively a new industry, which is beginning to assume larger proportions. Wherever preserving is carried on it should be with all the care of a chemical factory. The nature of the wood should be known, its stage of seasoning, its absorptive capacities, the absorption obtained in various runs, the temperatures reached during treatment-all these points and many others should be watched and recorded for future reference.

This naturally leads one to speak of the person who is to have charge of work of this character. I have repeatedly urged that the preserving problem, in its relation to the railroad and other industries using treated woods is a problem worthy of the undivided attention of a trained technical man.

A railroad should have a man who can deal with timber in its broadest sense. I do not mean a pur- 
chasing agent, but a technical man, who should have a position equivalent to the consulting engineer, reporting to the vice-president or general manager. He should be able to deal with forest lands in their relation to railroad supplies, with timber inspection, handling, treatment, and its final disposition. He should have authority to make investigations with competent assistants, so as to keep himself posted as to changes in methods, as to timber values, maintenance problems, etc., and his opinion should be that of an expert. So far as I know, only one railroad has so far created a position of manager of a tie and timber department in the sense indicated. It is particularly striking that this should be the Atchison, Topeka and Santa Fé Railroad, a road with the largest experience in timber treating of any in this country. The example which they have set should be followed by others.

In discussing preserving problems I have spoken largely of ties and railroad timbers because these forms of timber have so far been most frequently treated. Most of the preserving plants are either directly or indirectly connected with railroad operations. The chemical preservation of wood, whether it be against decay, fire, warping, stains, etc., will probably play an increasingly important part in the development of an economical utilization of forest products. Not only will it affect railway : and telegraph interests, but also in a smaller way each owner of forest lands and the smaller user of timber. Farmers have been using longlived timbers for fence posts. These are getting expensive in many parts and have to be shipped long distances. By treating the saplings growing on his own farm, each farmer will be able to make his own posts at slight expense.

The lumber interests will be influenced by the more 
general introduction of preserving processes. Woods which have had little value will find a market, and those woods which, in their untreated condition, are low-priced, will appreciate in price when once it can be shown how they can be treated to give them increased lasting power, or make them higher grade.

There is as yet no general appreciation of the fact that most kinds of timber can be successfully treated. Treatment is an exception and rarely considered either by the producer or consumer. We have been spoiled by the wealth of timber of superior qualities which we have had for many years, and it may take some time to effect a change. That this change is coming I feel sure of, and can prove it by the following extract from a letter written by a farmer in one of the northern states, who asks: "Please tell me how I can preserve maple fence posts to prevent rot at the ground. If you can't tell me how to make them last thirty years or more you needn't take the trouble to reply to this letter." 


\section{LETTER FROM JAMES J. HILL}

HoN. JAMES WILSON,

Secretary of Agriculture,

Washington, D. C.

Dear Mr. Wilson:

I wired you to-day my inability to be present at the Forest Congress, which I very much regret.

The subject is of importance far beyond the general understanding of the public. The growth of population in the United States has practically covered all the land which can be cultivated with a profit without artificial moisture. Irrigation and forestry are the two subjects which are to have a greater effect on the future prosperity of the United States than any other public questions, either within or without Congress.

Yours truly,

(Signed) Jas. J. HiLL. 


\section{PART VI.}

IMPORTANCE OF PUBLIC FOREST LANDS

TO MINING 



\section{THE DEVELOPMENT OF WATER POWER AS RELATED TO FOREST RESERVES}

\section{BY \\ A. L. FELLOWS}

District Engineer, United States Reclamation Service

L IGHT and heat, air and water, all earth's elements combine in the formation of a habitation fitted for her children. Nature has apparently employed all her many agencies and utilized all her generative forces in heaping up her bounteous and varied stores for the enjoyment of her creatures. Through untold ages she was engaged in preparing a home for her humbler children, and throughout the countless centuries that have passed since the earth was first fitted for the sustenance of life, she has continuously been perfecting conditions suitable for higher and yet higher species of living, sentient creatures, until, at the present time, man, that species which we in our self-esteem count highest of them all, holds the center of the stage.

Amongst the many secondary agencies which the great all-Mother has utilized in making this earth a habitation and a home for all her creatures, the forest stands almost preeminent. It has clothed the earth as with a garment, protecting it from storms and erosion. It has been the home of almost all varieties of land life from the lowest to the highest. It has saved its denizens from the rigors of the winter's cold and from the summer's scorching heat. Not contented with the bestowal of mere temporary benefits, it has stored up in the coal measures the heat and sunshine of summers long past for the use and enjoyment of 
the creatures of to-day. It is to-day, as it has always been, a most active agent in the preservation and upbuilding of the human race and a most important factor in providing in all ways for man's comfort. It furnishes him with both the necessities and the luxuries of life, nourishing his body and gratifying his soul's desires. From and through it have come the materials by which man has subdued both the land and the sea and, to-day, it is, as it has ever been, the benefactor of all, of "man and bird and beast."

Others have touched upon its importance as the source of our timber supply, the conservation of water for our irrigation projects, the chief dependence of our range industries, our railroads, our wood-working and publishing interests, and the general welfare of the public. I desire now to invite your attention for a few moment to its importance as a factor in the development of the waste power which lies dormant in all our running streams and upon which the future welfare of the entire country will so greatly depend.

The people of the United States are but just awakening to the great possibilities existing in embryo in our creeks and rivers. Electricity, that giant dynamic of the present generation and of countless generations yet unborn, is hardly more than in its infancy. Every stream, small or large, has potential power, which can be carried practically unlimited distances, at least several hundreds of miles, and can be used in any amount desired or in any desired combination with that derived from similar streams, though they may be many miles apart. One of the greatest needs that this country has to-day is a cheaper form of power, so that industries as yet undeveloped on account of the excessive cost of operation under existing conditions, may in their turn add to the national wealth. This is true 


\section{AMERICAN Forest CONGRESS}

along nearly all industrial lines, but the need is perhaps more pronounced in mining regions than it is elsewhere. By far the greater number of our ore deposits are of such low grade or are located so unfavorably with reference to the utilization of coal or the other more usual methods of power development that their economical operation is out of the question. In many of our mining camps coal costs from \$1o to \$I 5 per ton, and at many of the mines its delivery, even at such high rates, is impossible.

The only practicable power in such cases is that obtained from electrical energy, and it is to this force that mine operators are turning.

There is no doubt but that many times the amount of power used in mining operations at present could be utilized to advantage at prices that would well pay capital to furnish it, provided the means for creating the power could be depended upon.

Electrical power may be generated in many ways, but in none more practically or more beautifully than by the use of water. Here a great dynamic is utilized which would otherwise waste itself. We here avail ourselves of one of Nature's resources without in any way exhausting her reserve supplies as is done in the present wasteful use of coal. Conditions may easily be conceived-in fact, many such cases exist-where a given water supply may be utilized several times over in the development of power without diminution in quantity or deterioration in quality, and be used again finally for city water supply and in irrigation, and the day is not far distant when all of the mountain streams, with well sustained flow, will be utilized to an extent now hardly dreamed of.

The development of electrical energy on a commercial basis upon a given stream and with a given fall 
will depend upon a variety of conditions, and in nearly every one of these conditions the forestation or lack of such upon the headwaters of the stream plays an important part. First of all is the total amount of water available which must, however, be considered in connection with the nature of its discharge--whether perennial or spasmodic.

The ideal condition for a maximum development of power would be that prevailing under a reservoir so large as to be able to impound all the run-off resulting from precipitation in the given drainage basis and its complete regulation. To insure permanence in reservoir capacity, the water supply must be clear, free from the presence of silt resulting from erosion, and removed as completely as possible from evaporative influences. The maximum development demands that the entire quantity shall be under such perfect control that a little more or less as desired may be utilized at any given time; and that it be well sustained throughout the year or other long periods, approaching as nearly as possible a perfectly even flow, with but little, if any, more in May and June than in September, January, or any other month; since the power developed, to be of commercial value, must permit of dependence being placed upon it throughout long periods of time. Otherwise it will not pay to install and operate the necessary plants.

Such conditions as have been described are not often even approached in nature, but in many localities farseeing men are trying to approach them as nearly as practicable through the construction of great storage reservoirs and by forestation, and, where the headwaters have been denuded of the timber, by reforestation.

Here is, to a great extent, the keynote of the situation. Those regions that approach most closely to the 
ideal conditions are those which are densely forested and can, therefore, act as conservators of the water supply with the least artificial aid.

Forests aid in controlling the run-off. Compare two tracts similar in all other respects, but the one densely covered with a forest canopy, while the other has been denuded of such protection. In the first case the forest cover, with its attendant conditions of a more granular and porous soil, its humus and leaf mould, holds back precipitation instead of letting it run off as rapidly as it would otherwise do. The snows of winter cover the ground with comparative evenness, so that it is protected from rapid melting when the sudden warm periods come. The moisture, moreover, instead of disappearing rapidly as surface run-off, goes very largely into the ground to appear in the form of springs, perhaps months later, as seepage run-off. The same is true of the summer rains. Instead of the precipitation resulting from this cause converging rapidly into a great torrent sweeping everything from before it, the moisture goes into the ground to return again as run-off when it is more particularly needed, the otherwise torrential stream becoming well sustained and perennial.

From deforested tracts the run-off is much more likely to be beyond human control. Great floods made up from the converging streams carrying logs and debris of all kinds before them, sweep irresistibly down the river valleys, taking with them diversion dams, gates, power plants, and destroying what they cannot carry away.

Then again, in a well forested tract, if over-grazing, with its attendant ills, has not been tolerated, there is usually a dense undergrowth, which retards the runoff during rapid melting or after violent storms. Its 
tendency in these particulars is to cut off the crest of the destructive floods, depriving them of their power to do harm.

The presence or absence of forests undoubtedly has a marked bearing, too, upon the quantity of the runoff. This effect varies with a number of different conditions, chief amongst which are the permeability and porosity of the soil, the different habits in different species of plant life in the matter of transpiration and the differences in evaporation influences. The soil conditions have already been touched upon. Retention of a large part of the precipitation by the soil instead of its being permitted to flow off rapidly may, and probably must in many localities-as, for example, in the arid regions-result in a decreased total run-off owing to the probably greater increased "fly-off," as the sum of the evaporation and the transpiration is sometimes termed. This diminution in the total quantity is, however, considerably more than offset by the advantages incident to a regulation of the run-off and consequent increase in the low water discharge. As our old friend "Mike" once said: "It's better to have a little liquid refreshment when you need it, than to have a high old time twice in a year."

It has been demonstrated that evaporation, greatest of all from a water surface in the open, is nearly as great from a wet earth surface similarly situated, and that the evaporation from a tract surrounded by forests is far less than it is from otherwise similar, but unprotected areas, this being due principally to the characteristics of the forest as a modifier of temperature and as a wind-break and shield.

This matter has been discussed at length by Mr. G. W. Rafter in a number of valuable papers, in which he shows beyond doubt that in humid regions at any 
rate the fly-off is materially less in forested than in unforested tracts.

In the matter of transpiration, also, it has been shown that the amount transpired from the forest growth is considerably less than it is from cultivated crops. These matters have been carefully gone into in $\mathrm{Mr}$. Rafter's papers, already mentioned, in Dr. Fernow's book, "The Economics of Forestry," and in Prof. Toumey's discussion of "The Relation of Forests to Stream Flow," as well as in many other important papers.

The conclusions reached are, in effect, that as between forested and unforested tracts, the quantity of run-off is materially augmented in the former case in humid regions where rains occur with more or less frequency, but that in arid regions, where precipitation occurs but rarely, that the retention of the moisture by the forests results in some loss in total run-off, which, however, is more than compensated by the greatly increased flow during the periods of minimum discharge.

Another important result of forestation must also be considered in this connection. It has been stated that the ideal conditions prevail when the total runoff can be controlled at will, the water being stored in great reservoirs. In a great many instances those who are interested in the development of power are endeavoring to attain these ideal conditions as nearly as possible, through the utilization of natural reservoir sites. Here, too, the forests serve a most useful purpose by preventing erosion. A tract of land that has been denuded of its supply of timber, especially when the denudation is due to fires so fierce as to destroy the humus and leaf mould with the vegetation, immediately becomes subject to the action of storms and the torrential run-off resulting in the rapid erosion 
of the soil, and thus filling the reservoir with silt and debris, shortens their periods of usefulness, and destroys their efficiency. That deforestation does result in an increase in the amount of sediment conveyed by the running water has been amply demonstrated by investigations carried on both in this country and in others. All measurements of silt, so far as is known, indicate that the run-off from unprotected areas is much more heavily laden with gravel, sand, earth, and organic matter than is the discharge from areas well protected by forests.

Where storage is not practiced, forestation still remains an important factor in power development, since a requisite of the utilization of the water supply for this purpose depends to some extent upon the freedom of the water from impurities. The presence of a greater or less quantity of silt or sand in the water supply has an important bearing upon the longevity of the machinery, especially the cups and bearings of the impulse wheels. The more rapid deterioration in the machinery may represent a very greatly increased cost in the development of power and a consequent limitation to its sphere of usefulness.

Practically all that has been said concerning the development of electrical energy is applicable also to the development of power directly and through the compression of air through the agency of water falling through a shaft, a process which it is predicted will become much better known and utilized in the future than it has been in the past.

Having established the fact that there is a close relation existing between forests and the development of power through the medium of our streams it is an easy task to demonstrate the necessity for forest reserves and for their proper control and management.

It is clear that forest lands still remaining in the 
Government possession should neither be allowed to pass into private ownership nor should they remain part of the unregulated public domain, especially under the conditions that prevail at the present time. In the former case, where such lands are permitted to pass into private ownership, human nature remaining as it now is, the controlling impulse will be to get the most money possible out of the land in the shortest possible time. This will usually result in the clearing off of the timber by the wasteful methods now practiced, without thought for the future. Reforestation will not be carried on, and the certain result will be the rapid denudation of all our forested areas.

Again, it will not do for the methods and regulations now in vogue with reference to the use of timber upon the public domain to be continued, since it inevitably results in the breaking out of forest fires and the wanton destruction of great bodies of timber, in addition to the great amounts of timber of which the Government is annually robbed. In investigations which have been made under my direction it has been clearly shown that many fires that had broken out in thickly forested districts of the public domain had been followed within a year or two by requests for Government permits for the use of the fire-killed timber left standing, which often makes the very best mine and tunnel timbers.

The forested areas must be watered and the cutting down upon them must be regulated. The grazing must be restricted so that the grass and other vegetation shall not be destroyed. Deforested tracts must be reforested and only by the establishment of forest reserves and through their proper control by trained foresters, can we approach to the most ideal condition possible for the conservation of our water supply-a forest growth covering their headwaters. 


\section{WILL THE ADMINISTRATION OF THE FOREST RESERVES ON A CONSER- VATIVE BASIS RETARD THE DE- VELOPMENT OF MINING?}

\section{BY \\ SETH BULLOCK}

supervisor, Black Hills Forest Reserve

THE request of your honored President for a paper from me to be presented before this distinguished gathering was a genuine surprise, as I am not an adept in that line of forest reserve work. My first impulse was to decline the honor, but after considering the proposition in all its phases, I concluded that in view of the recent favorable legislation by the Congress of the United States, looking towards the placing of the forest reserves and the forest reserve officials in the department so ably administered by Secretary Wilson, that it would be wise for me to endeavor to comply with the request of President Wilson, and if the paper prepared should merit any punishment I could enter that time-honored and usually successful plea of self-defense in mitigation of my sentence. The question upon which I am requested to enlighten this aggregation of diversified wisdom is, "Will the administration of the forest reserves on a conservative basis retard the development of mining?" To properly arrive at an understanding and solution of this question (and I assure you that it is a large one), it will first be necessary to determine to what extent the mine is dependent on the forest, and I wish it to be understood 
that my remarks will refer chiefly to the conditions existing in the Black Hills Forest Reserve, the only one of the larger timber reservations with which I am thoroughly familiar.

Nearly all the developed mines of the Black Hills are large deposits of comparatively low grade gold ore, either free-milling or cyaniding in its character; frequently both processes are combined in the extraction of the values from the ore. In the successful prosecution of the work required to make a mine productive and remunerative to the owners, the use of timber is an absolute necessity. Its uses are varied. It is required to timber the shafts through which the ore is drawn to the surface. Heavy timbers are also required to take the place of the ore mined, to hold up the roof of the workings and sustain the sides of the stopes and drifts. The place of every supporting atom taken from the interior of a mine, like the Homestake, for instance, must be filled by some other material which can carry the burden with safety to the lives of the miners employed. This requires timber from the forest. No other material can be substitued for it. The use of iron or steel posts and beams is prohibited by their cost, to say nothing about their inadaptability to the work of underground mining.

To form some idea of the large amount of timber used by a mine of the magnitude of the Homestake, it is only necessary to state that over one and onequarter million tons of ore are annually extracted from this property, practically all of which is taken out at a greater depth than 500 feet from the surface of the ground. Its deepest workings are, I am informed, over I,250 feet.

It can be truly said that a veritable forest has been used under ground in the mines of the Black Hills 
during the few years they have been in operation; that no more of the forest has been used in their development than has been absolutely necessary, is doubtless true. The grade of the ore, the high wages paid, and the satisfactory returns received in most cases on the investment, prove that the mines have been most economically managed, the timbering being one of the heaviest items of expense in their operation.

In addition to the timber used under ground in precious metal mining, large quantities are required on the surface in the erection of ore reduction works and buildings required to house the machinery necessary in conducting the business of the mine.

The question of wood for fuel is in some districts an important one, which happily has been in a measure solved in the Black Hills in recent years by the advent of railroads, 'connecting the mining districts with the coal fields of Wyoming, enabling the mines to secure a better and more economical fuel than that afforded by the forest wood.

Another important factor in the business of mining as conducted in the Black Hills, fully as essential as timber, is an ample supply of water; for if this is insufficient, the separation of the values from the mined ore would be impossible and the labor and expense of mining lost. As it is necessary, owing to these low grade ores that the stamp mills or reduction works be placed as near the mine as possible, large sums of money have been expended in supplying these plants with water which is derived from mountain streams, the continuous flow of which is dependent upon the preservation and maintenance of the forest conditions at their source; the fact being now unquestioned that the denudation of the timber and forest cover, and the removal of vegetation at the supply points of our 
mountain streams, seriously check their flow and will in time cause their disappearance.

"Before these fields were shorn and tilled,

Full to the brim our rivers flowed.

The melody of waters filled

The fresh and boundless wood.

And torrents dash'd and rivulets played,

And fountains spouted in the shade."

The dearly bought lessons of the East should be heeded by the West.

The benefits derived by the stream from the forest are amply repaid by the increase of life-giving moisture in the air and soil. The stream is also a friend in need to the forest when attacked by its arch enemy, fire.

It follows, then, that the forest and stream are dependent each upon the other and successful mining upon both. The dependency of the mine upon the forest having been established, the question arises, What is the best plan for securing a permanent supply of the necessary timber? My reply is: intelligent and practical forestry which can best be obtained under forest reservation administered with business-like methods. That the cutting of timber upon the public domain should be permitted only under wise legislation is a self-evident fact, approved of by every one acquainted with the subject. When no restrictions were placed upon it, these cuttings have nearly all resulted in the total disappearance of the forest. To prevent future destruction, forest reserves have been established and to them should be given the same management that a prudent merchant accords to his business. No wise merchant would hold his goods until shopworn and old, neither would he dispose of all of them without taking the necessary steps to replenish 
his stock. Our system of forest reservation, as at present conducted, has been established but a short time, the first public timber sale under it having been made in November, 1900. Since then giant strides have been made in protecting the forest from waste, depredation and fire, and the pronounced benefits arising are apparent to the most casual observer. At first, the plan met with considerable opposition, principally because it was not understood, but as the policy developed, the people began to realize that forest reservation meant a saving of the wicked waste so marked in all former logging enterprises, a just price for the timber sold, a protection of the forest from fire and thieves, a conserving of the streams, a preservation of the young growth, the utilization of the dead timber; in fact, that it meant more timber for their use and benefit. Now practically all opposition to forest reservation has disappeared and to-day it has the hearty good will and support of every honest man in and about the reserve.

The present system could be improved upon by replanting and reforesting. In successful forestry there should be a seed time as well as a harvest. Denuded areas in and adjoining the reserves suitable to the growing of timber should be planted with trees adapted to climate and soil. This, with a practical administration of the forest reserves, an administration beneficial alike to the forest and the mine, one that takes into consideration not only the preservation and propagation of the timber, but the necessities of the mine as well, and that gives to the latter the most liberal treatment compatible with the permanency of the forest, will not, in my opinion, retard the development of mining, but, on the contrary, materially assist it. 


\title{
IMPORTANCE OF THE PUBLIC FOREST LANDS TO MINING
}

\author{
BY \\ T. J. GRIER
}

Superntendent, Homestake Mining Company

I. THINK our President made a mistake when he asked me to address the array of talent I see before me here today upon a subject of such far-reaching and vital importance as is indicated in the title to this paper, and I am sorry, therefore, that he did not go farther and secure for your entertainment someone better able to give the subject the careful and exhaustive review it deserves.

Responsive to the query suggested by the title, permit me to suggest that "Forests help mining" in much the same general way that they help all other industries which require forest products. The forest furnishes the supply; the industries make the demand. The main and chief products of the forest being wood and water, I fear that the progress of very many of our great industries would not be rapid if they were deprived of those articles. The importance to the nation's great industries of the forest therefore is not questioned, but a very great deal of interest and importance is centered in such conservation of it as will enable it to meet the great and growing demand of those industries.

The question of tree supply and demand presents itself for that solution which will bring about an ample and increasing supply to meet an ever-increasing demand that is being made upon it. I trust that the 
deliberations of this Congress may point the way to that solution.

Prodigal in the use of our woods, and forgetful of the resulting damage to our mountain streams and springs, perhaps we have too long neglected the care of our forests; or does our rapid progress in the development of the manifold resources of this country, which calls for generous quantities of forest products, merely lead us to imagine that such is the case? I incline to the former belief, and I think that a visit to the denuded areas within regions once forested, and to the dry places where springs of clear water once flowed, will bear me out. If this is true, we must meet the demands of such rapid progress, or a halt must be called.

I do not believe that the American people are built upon lines that would make palatable the calling of a halt in their onward march, but that, the necessity being made apparent to them, they will rise to the occasion as one man, and with all of the energy with which they are by nature endowed quickly set about correcting the sins of omission of which they have heretofore been guilty.

Fresh from the southwestern corner of South Dakota, the former home of the Sioux Indians, who once thought, and perhaps yet think, that in defending their forest home death in tribal warfare was an honor rather than a calamity, and where $I$ have resided for over a quarter of a century, I have noted with much concern the slow but sure dwindling of the forest. Although the extensive operations in that region of the great mining industry with which $I$ have been connected have during that period been conducted, and are still being pursued, with the view of conserving the forest, the dwindling of the forest area still goes 
on. In the pursuit of this policy of forest conservation it is only right to say that the forest has been the gainer, while the mining company has been the loser. The company I have the honor to represent; in using wood as fuel instead of coal, does so at a material loss, because the only wood used for fuel in the Black Hills is the dead, down and insect-infested trees which the departmental regulations very properly insist shall be removed from the forest. Such very inferior material costs the mining industry and all other industries using it approximately Ioo per cent more than coal for either heating or steam-making purposes. If a suggestion in this connection is pertinent, I desire to say that the Government should give such material for the taking, so that the consumers of forest products who can and are willing to conserve the best interests of the forests by taking the inferior stuff should not be compelled, through having to pay for it, to bear an excessive share of the burden of cost of forest conservation. The Government enjoys excessive gain in having such refuse removed through promoting, in a material degree, the health and thrift of its green trees that remain. I think that should satisfy it. Its gain, however, does not stop there, because the removal of this débris practically eliminates all danger of loss or damage to the green trees from forest fires. Trees breathe, digest their food, live, thrive, sigh, and die much as we of the higher order of animals do; therefore, if the fittest are to survive and thrive, the conditions around them must be favorable and the elements of danger must be removed. I think the forest supervisors and rangers, and the scientists from the Entomological Division and the Forest Bureau who have made so careful a study of this subject and these conditions will second this suggestion. 
Forests are important to mining, and benefits accrue to mining from forests; but it is not sufficient to say so and there stop. The forests are an absolute necessity to the mines. Nor is it true to say that the timber produced by the forests is the only benefit accruing from them. Conservation of water by a thrifty growth of trees is to the credit of the forest, while alike important and necessary to the mineral industry, and when that water is thus conserved it becomes invaluable as it flows upon such agricultural areas as may be adjacent to the mineral lands. I say adjacent, but I do not mean within the exterior boundaries of the mineral zone, because I do not believe that the narrow strips of soil oftentimes found alongside of mountain streams which have cut through ledges of metal-bearing rocks and which consist largely of the erosion of those rocks constitute agricultural areas entitled to consideration or rights equal in any degree with the rights of the mines. And I think any legislation looking to the giving of grants to such so-called agricultural areas a hindrance and stumbling block in the way of progressive and successful mineral development.

Not many, perhaps, fully appreciate the enormous quantity of timber needed in and about a great mine in order to carry on its operations and protect the lives of its operatives. The hoisting works, metallurgical, and other buildings on the surface which are always in sight perhaps render the casual observer unmindful of the fact that further supplies of the forest product are required with every foot of progress made in penetrating underground. As the miner's work of taking out the ore advances, he surrounds himself with a framework of timber which is intended to hold in place the sides and roof of his excavation. Wherever it is possible to hold in place these sides and roofs with 
waste rock instead of timber it is done; so that there need be no division of opinion as to the willingness of the miner to adopt such practice whenever it can be done. The better protection of his property from disastrous caves suggests it; the protection of his operatives makes it imperative; it is cheaper.

It is true that a substitution of metal for wood in certain permanent improvements about the works of some of our great mines has been made, and it is probable that wood will continue to give way to iron, steel, and possibly other non-combustible materials in limited extent. At the every-day task of mining ore and developing underground, however, I do not anticipate any such substitution, nor do I think that the importance of the public forest lands to mining will be lessened by the change in practice in making such permanent improvements, because of the small ratio the consumption by such improvements bears to the whole.

I am not familiar with all of the conditions that now surround the several areas in the United States which constitute its forest reserves, or that surrounded those areas when the reserves were created, but I have intimate knowledge of the conditions which prevailed and surrounded the home of the Sioux Indian up to the spring of 1877 . Inasmuch as Article II of the By-laws of this Association suggests, as one of the objects of its being, the advancement of such legislative measures as the Association thinks may tend to promote the general welfare of forests, I am persuaded to call the attention of this Congress to the importance of considering well such local conditions as may be found at each and every reserve before advancing general legislation, the operation of which would affect all of the reserves alike. I further desire to submit to the 
attention of the Association the fact that there are certain conditions in and about the Black Hills Reserve which should not be forgotten when suggesting laws, rules, and regulations for its government. In the first place, it will be remembered that the Black Hills Reserve was the home of the Sioux Indian until I877, and that the Government, having satisfied itself that there was within the exterior boundaries of that home a valuable mineral kingdom, arranged for the red man to vacate the premises. Announcement of the new find was then rade to the world, the area was platted on the Government maps as a mineral zone, and the miner was invited to enter, explore, and develop the zone. The miner came upon this invitation, has been diligent ever since, and has invested millions of dollars in exploration, development, and improvements, relying in the prosecution of his work upon having the full benefit of all of the natural resources of the country, and without which his work cannot continue successfully. - I therefore submit to this Congress that it will be manifestly unfair to advance any legislation having for its effect the depriving of the Black Hills miner of those natural resources in any degree.

Touching another subject, suggested in Article II of its By-laws as justification for the being of this Association-the advancement of educational measures tending to promote forest welfare-I think that we may confidently rely upon that department of the Association which will have in hand the dissemination of knowledge relating to forest welfare to do its duty.

Fully realizing that the benefit of the forest to mining is of such importance that it can only be appraised by giving it the value that attaches to an absolute necessity, and that much value also attaches to the forest in its relation to the other great industries 
of the country which, combined with the mineral industry, go far towards making the nation the great, glorious, and prosperous whole that it is, I cannot refrain from suggesting at this time that the custodian of the public domain and its natural resources should not be unmindful of the immense value to it from the operation of those combined industries.

While the receipts and expenditures of all industries except mining can be so fixed as to return interest on the investment, and that such industries have practically life in perpetuity, it is not so in the mineral industry. With it the day comes when, after having given to the country their treasures, the mines, one by one, become exhausted, and their costly improvements are allowed to decay. Is it asking too much, then, that the mineral industry be most considerately treated by this Government? If not, most liberal should the consideration be that is given to the precious metal mines which furnish the foundation of the nation's credit, and which saved that credit from annihilation after the civil war.

I become more and more impressed with the necessity of tree planting to insure forest perpetuation and enlargement, and to insure the maintenance of streamflow, and $I$ am amazed at the indifference upon the subject so long displayed by a people otherwise so mindful. Dwelling upon the subject for a moment, I next wonder how the tree planting can be most successfully and economically accomplished, when something says to me it can be done by the forest rangers. I submit the thought for your consideration.

Will you bear with me a moment longer, Mr. President, and gentlemen of the Congress, while I call attention to a condition obtaining in and about all of the forest reserves of the United States, and which 
looks to me to be very unfair to a few of the great industries operating about and within those reserves. Under the presidential proclamations creating the reserves, and under the laws as they now exist, it is not possible for any industry-railroads and irrigating companies excepted-to be made secure in the possession of a right of way extending through a forest reserve. Is that fair? Is there any reason why a great mine, after spending a large sum of money in constructing a waterway through a reserve for the purpose of bringing a supply of water to its works and to the people manning those works, should not be able to get as good title or right of way for such conduit as is given to the irrigating company or to the railroad company that builds a line through the same reserve in order to haul other kinds of supplies to the same works and to the same people operating the works?

Under the laws and proclamations creating the Black Hills forest reserve the miner is protected in the possession of such mining locations as he possessed at the time of the creation of the reserve. Further than that, he is permitted to make new and additional locations. Both these provisions are just. They are, however, inadequate. They stop short of giving that protection to which the mining industry in the Hills is justly entitled. The absolute necessity of water for the development of the mining claim is universally conceded. The United States Government recognized this necessity. It has thus far failed, however, to make adequate provision to enable the miner to secure himself in the possession of this necessity. Since 1866, the Government of the United States has granted to the miner the right to construct upon its public lands ditches and flumes to conduct the waters of the streams required 
in legitimate mining operations. It has in effect granted rights of way across such public lands for such ditches. It has provided that all patents issued shall be subject to such ditches and rights of way. This eminently just and wise policy seems to have been suddenly abandoned in regard to those lands comprised within forest reserves. Since the creation of these reserves there has been, so far as I am advised, no provision made by which the miner can secure the grant of a right of way for his ditches and flumes, without which his property may be utterly valueless.

It is true that the act of February 15, I90I, entitled "An Act Relating to Rights of Way Through Certain Parks, Reservations, and Other Public Lands," does provide that the Honorable Secretary of the Interior may permit the use of rights of way through the forest reservations for ditches and flumes used in connection with.mining and other operations. But the authority conferred upon the Honorable Secretary is so emasculated by the concluding provision of this act as to leave him in effect no authority to grant any substantial right, but unlimited power to revoke the favors already conferred. That proviso reads as follows: "And provided further that any permission given by the Secretary of the Interior under the provisions of this Act may be revoked by him or his successor in his discretion, and shall not be held to confer any right or easement or interest in, to, or over any public land, reservation or park."

I particularly call your attention to Regulations No. 2 and No. II promulgated by the Honorable Secretary under this act. (Circular July 8, I90I).

No. 2 reads as follows: "It is to be specially noted that this act does not make a grant in the nature of an easement, but authorizes a mere permission in the nature of a license, revocable at any time." 
No. II reads as follows: "Upon receipt of applications for right of way by the General Land Office, the same will be examined and then submitted to the Secretary of the Interior with recommendation as to their approval. Permission to use rights of way through a reservation or any park designated in the act will only be granted upon approval of the chief officer of the department under whose supervision such park or reservation falls and upon finding by him that the same is not incompatible with the public interest. If the application and the showing made in support thereof is satisfactory, the Secretary of the Interior will give the required permission in such form as may be deemed proper, according to the features of each case; and it is to be expressly understood, in accordance with the final proviso of the act, that any permission given thereunder may be modified or revoked by the Secretary or his successor, in his discretion, at any time, and shall not be held to confer any right, easement, or interest in, to or over any public land, reservation or park. The final disposal by the United States of any tract traversed by the permitted right of way is of itself without further act on the part of the department a revocation of the permission so far as it affects that tract, and any permission granted hereunder is also subject to such further and future regulations as may be adopted by the Department."

In short, gentlemen, the miner who, at a cost of thousands, nay hundreds of thousands of dollars, has constructed his ditches across the public lands of the reservation in order to make profitable a mining property otherwise idle and worthless, holds his investment of dollars and brains subject not only to the changing policy, to say naught of the whims and caprices, of an administrative officer of the Government, but, what is 
a far more serious danger, subject to the blackmailing schemes of the mine adventurer who, by obtaining a patent for one mining claim across which the ditch is constructed, has the absolute power of obstructing the operation of the ditch and thus of the mine.

Certainly, such results could not have been foreseen by our law-makers. But they are not only probable; they are inevitable. There is a remedy-simple, speedy, just-and that is a law promptly giving to the miner the same rights given to railroad corporations and irrigating ditches; at least, a law by which the miner in a reserve is protected to the same extent that he is protected upon public lands not within a reserve. The law, as it stands, puts a premium upon the dishonesty of the nomadic mining adventurer. It offers no protection whatever to the bona fide miner. It should be promptly amended.

For the respectful attention given to a few thoughts of a brand-new member of your Association, hurriedly incorporated into a so-called paper, I thank you, gentlemen, most heartily. 


\title{
MINING IN THE FOREST RESERVES.
}

\author{
BY \\ MAJOR F. A. FENN \\ Supervisor of Forest Reserves in Idaho and Montana
}

I $\mathrm{N}$ many of the Western States where forest reserves have been established, mining holds the foremost place among our industries. With coal mining we have little to do; hence, in the remarks that I shall make, the term mining will be confined to metalliferous mining. No other industry is more directly and intimately connected with the administration of forest reserves than mining. The preservation of timber and the conservation of the water supply - the two great purposes of the forester-are exactly suited to meet the demands of the two chief branches of the mining industry, lode mining and placer mining. The lode miner must have timber for his underground workings; and without water, the placer miner is helpless. The Government has ever guarded the miner's interests most carefully. Every inducement has been given. the prospector, and the development of the mineral resources of the country has been encouraged and stimulated. Consistently with its steadfast policy, Congress took pains to see that the law authorizing and setting apart portions of the public domain as forest reserves should contain nothing of detriment to the mining industry. The act of June 4, 1897 (commonly called the Forest Reserve Law), among other things provides as follows:

"It is not the purpose or intent of these provisions, or of the act providing for such reservations, to author- 
ize the inclusion therein of lands more valuable for the minerals therein, than for forest purposes."

And further: "Nor shall anything herein prohibit any person from entering upon such forest reservation for all proper and lawful purposes, including that of prospecting, locating, and developing the mineral resources thereof: Provided, That such persons comply with the rules and regulations covering such forest reservations."

And further still: "And any mineral lands in any forest reservation which have been or which may be shown to be such, and subject to entry under the existing mining laws of the United States and the rules and regulations applying thereto, shall continue to be subject to such location and entry, notwithstanding any provisions herein contained."

While the act contains the above-quoted provisions, it also outlines a plan for the preservation of the forests within the reserves and gives to the Secretary of the Interior power to elaborate the system and make it effective, by authorizing him to "niake such rules and regulations and establish service as will insure the objects of such reservations, namely, to regulate their occupancy and use and to preserve the forests thereon from destruction."

Realizing the vital importance of the mining industry to the national prosperity, and at the same time appreciating the necessity of protecting the forests for the benefit of the people, the law-makers devised a scheme of forest protection that enables forest reserves to be maintained and the mining industry to be carried on simultaneously in the same territory, not only without conflict or friction, but in such manner that scientific forest methods may be applied in fullest measure, while the best interests of the bona fide miner are subserved and promoted. 
Under the same law, the authority given the Secretary of the Interior to prescribe rules and regulations to effectuate the system outlined in the law, provided the means whereby the details of the reserve policy might be worked out and adapted to the conditions of the mining industry as they should be encountered in the different localities where mining interests and forest methods might come in contact. The scheme devised enables every miner to secure from forest reserves in the State in which his mines are situated whatever timber is necessary to the prosecution of his enterprise.

Prior to the enactment of this law, a different condition prevailed. Before the act of June 4, 1897, was passed, almost the only way for the miner to obtain timber from the public lands legitimately was under the act of 1878 , which allowed the cutting and removal of timber from public mineral lands for mining and other specified uses. This act placed miners in an embarrassing position. Under the general laws, and according to the policy of the Department of the Interior, the public lands are presumed to be non-mineral, and held to be such until the contrary is shown; hence, to justify the cutting and removal of timber from a given tract, under the provisions of the act of 1878 it is incumbent upon miners to be in position to show that the land involved is mineral in character. This necessitates the discovery of mineral; for ordinarily the fact that some mines are known to exist in a certain region does not establish the mineral character of the whole territory included. To demonstrate by prospecting or otherwise that a particular tract from which it is proposed to cut timber is mineral lands, is to invite the location of it by others as mining ground, and thereby defeat the very purpose of the person needing the timber; for, under the mining laws, the locator has the 
right of possession, and is entitled to the exclusive enjoyment of the surface of the ground located. The consequence has been that no effort to determine the real character of the land was made, the needy miner preferring to take the timber on land separated from his claim and run the risk of being brought before the court for cutting and removing timber from public lands illegitimately, rather than to place the timber beyond his own reach through proving the tract to be mineral in character, and assure its subsequent location by interested parties, who would surely take advantage of the showing made, to their benefit and to his injury.

It may be suggested that the person desiring the timber might himself locate and secure control of both timber and land; but the reply is that the law as construed requires that the timber cut from a given claim must be used on that claim, or on a group of which that claim forms a part, and cannot be removed for use on a different claim. This most annoying complication has been fully appreciated by the Government and by courts, and the result has been that really very little regard has been paid to the character of the land from which timber was cut for mining purposes. The condition precedent to justify the cutting was practically neglected, and it was deemed sufficient that the timber taken was devoted to a use contemplated in the law. The necessities of the miners, and the peculiar provisions referred to, combined to make the majority of the miners of the Northwest law-breakers. In fact, few miners knew the exact requirements of the law. It was commonly understood that whatever forest products might be needed could be taken anywhere any at any time. This erroneous view often resulted in prosecutions, which usually terminated in acquittals that have brought discredit upon the administration 
of justice in the far West. Now, happily, this deplorable condition of affairs is obviated through the passage of the Forest Reserve Law, and the bona fide miner is given opportunity to secure timber in a legitimate manner from the public lands.

This one point alone, gained through the development of American forestry, should commend the system to every person truly interested in the continued prosperity of the mining industry. Still, the difficulties mentioned might have been overcome by direct legislation, and the vital matter of forest preservation left untouched.

Every successful lode mine is a consumer of enormous quantities of forest products. Such properties as the Homestake mine in South Dakota, the great copper mines of Butte and Anaconda in Montana, or the lead-silver producers of the Coeur d'Alenes in Idaho, require almost incredible amounts of timber for their operation. While commonly there is naturally a fair supply of timber in the mountainous regions where such mines are found, it is far from inexhaustible. The first impulse of the miner in the hurry and scurry of the newly discovered mining region is to cut and slash indiscriminately. He takes a tree here, another there, as his immediate needs may suggest. $\mathrm{He}$ gives no thought to the refuse from his cutting. $\mathrm{He}$ is heedless of the damage that may be done to the remaining timber, and he is utterly extravagant in the use of that which costs him nothing, and which there is no one to claim or protect.

What might be expected, ensues. Fires start in the cut-over tracts, spreads through the accumulated débris to the adjacent forests; and the country for miles around is devastated. Recurring fires continue the destruction, and in a relatively few years the mining 
camp is surrounded by denuded hills, and the miners are face to face with the timber famine, the penalty of their own thoughtless extravagance and carelessness.

Another cause of destruction is the wanton burning of forest cover where brush and other material impede the hasty work of the prospector. Too often it occurs that the prospector, his imagination fired by finding a rich piece of float, without thought of the injury he may do to others or even to himself, deliberately sets fire to the forest to clear the ground and facilitate his operations. Not only is immeasurable damage done to the mining industry at large by such criminal practices, but the fire-bug is likely to render the mine, if he discover one, wholly valueless, because of the destruction of timber on which successful operation of the property may depend.

It is useless to cite examples to illustrate what has been said concerning the destruction of timber in the vicinity of mining camps by prospectors. The experience of any practical miner is sufficient to prove the correctness of what is stated.

The preservation of the forests in a State of highest continued production involves the economic use of timber, encouragement and stimulation of reproduction, and protection from fire and spoliation.

It frequently happens that mining properties are found at altitudes where the better grades of timber cannot grow. Such species as are adapted to these high elevations rarely attain dimensions suitable for ordinary commercial purposes; and again, too, the stand is limited, so that he who appreciates the situation must realize the vital necessity of husbanding the available supply. In spite of these conditions, however, miners, particularly in the boom days of any 
mining camp, are, as before stated, prone to extravagance in the use of timber and to be careless in their methods. After a few years of stuch work, the increasing cost of forest products and the rapid diminution of the supply arouse consumers to their early folly, and stir them to an appreciation of conservative forest methods and to the importance of enforcing them.

But at this stage, proper protection of the young growth is most difficult. The needs of the consumers prompt the cutting of immature trees for all purposes where such timber can be utilized; and to withhold such material is, under the circumstances, looked upon as a hardship. Large areas are now in process of reforestation around many mining camps, where repeated fires, following in the wake of choppers, have cleared off the remnants of the original forest and also destroyed one or more second crops that have sprung up. The present growth is frequently sparse in consequence; but it is usually largely composed of lodgepole pine, a variety of timber fortunately well suited to many of the miner's purposes when it is mature, but not calculated for any other use than lagging when in the sapling stage. This timber, too, is largely a preparatory crop, which nature provides to fit ares that have been devastated by fires for the growth of other and more valuable varieties of timber. This is a critical time in the process of reforestation, and it occurs just when the miner is experiencing the first pinch of timber famine, and he looks with longing upon the growing trees that might be employed as a makeshift to tide over present difficulties; hence, the apparent hardship. A comprehensive view of the situation will convince him that the ultimate good of the industry he represents will be advanced by prac- 
ticing the most rigid economy in the use of this immature timber and by husbanding it and stimulating its growth to insure a later abundant supply.

Right here I would call attention to the possible shortage of timber in certain reserves where the demands of miners may be most urgent. I have in mind the Black Hills Forest Reserve, in South Dakota. Vast mining interests are at stake there; at present there is an apparently sufficient supply of timber in the reserve to satisfy the needs of the mines, but the appearances are deceptive. The forests are badly infested, the pine beetle is doing his deadly work; and unless the ravages of the insect be stopped, the present forests of that reserve within a relatively short time will have been destroyed. Investigations made by competent forestry officials have proven that a remedy for the evil exists. The infested timber must be promptly cut down and the breeding places of the beetle sought out and the insects exposed to the elements and killed. This heroic treatment fills the minds of Black Hills miners with apprehension. They therefore object to it; they fear that if this now infected timber be all cut and removed they will be left without any available timber. Such a result would indeed be disastrous; but by opposing the cutting and removal of the timber beyond the present needs of the consumers, the evil will not be eradicated ; further destruction is a certainty so long as the insects are allowed to harbor and propagate there. By thus procrastinating, the suffering miners but increase their difficulties; and if things be allowed to drift along as they are now going, not only will all the timber, young as well as old, be destroyed, but the possibility of a future crop will disappear. Now it would appear that if there is any chance for a supply of timber for present 
needs from the public lands to be assured for use in the mines in the Black Hills, the wisest course would be for every tree in the affected district to be cut and the threatened disaster averted, while at the same time the present young growth could be given an opportunity to develop and become valuable, free from the blighting influence of the now tireless pest. Such a cutting would result in throwing a vast amount of timber on ine market at once, an amount far beyond the demands of the day in that immediate vicinity. To attempt to retain it until the local market could dispose of it, would be to allow a large part to rot on the hands of the Government. Wastefulness of that character would be criminal. The only reasonable course would be to ship the stuff to other points, to other States probably for consumption. The law, however, prevents such shipments; timber cut from public lands may not be transported outside the State in which it is cut. Here is a dilemma. If the timber be not cut, the forests will be irretrievably ruined; if it be cut, it must be either burned or allowed to rot on the ground instead of being utilized to satisfy the wants of people in other States which nature has not blessed with timber growth.

If the timber could be cut from public lands in one State and shipped to other States, the solution of the difficulty would be easy. The insect-infested timber could be cut and the surplus exported to other localities; and then, whenever the needs of the miners of the Black Hills should require it, the forests of Oregon, Washington, and northern Idaho, where there is no local demand at all, could be drawn upon for an indefinite time and until the young growth in the South Dakota hills should be again adequate to the necessities of the people there. 
The present law on this point should be changed. Instead of remaining inflexible, as it now is, positively prohibiting the exportation of timber cut from public lands from one State to another, the law should be so modified as to allow the department in charge of the forest reserves in its discretion to authorize such exportation when the interests of the people would be subserved and the forest reserves benefited or at least not injured thereby.

It should not be understood that the present legal difficulty is applicable only to the case cited above. In many of the great forest reserves of the Northwest, where there are hundreds of millions of feet of mature timber which is deteriorating in value every day, there is no local demand; the lumber manufactured in Oregon, Washington, and northern Idaho is practically all shipped to markets outside those States. Because of the inhibiting law now on the statute books, the reserve timber cannot be utilized. It must remain neither useful nor ornamental, and finally die and rot where it grew; while the people of the prairie States of the Middle West appeal in vain for that which they so much need, that which they might have but for this absurd provision of a law enacted long ago to meet conditions that no longer exist. The incongruity of things is manifest.

This Congress is deliberating here for the purpose of encouraging and making practicable an American forestry system, a system national in its scope; while the law referred to renders impossible the application of some of the most fundamental principles of true forestry by circumscribing vast areas of available mature timber by the impassable barrier of a State boundary line.

The economical use cannot subserve the miner's 
needs unless it be supplemented by adequate protection against fire; and here is where an intelligent forest patrol is a necessary auxiliary to the mining industry. Protection from fire makes requisite certain precautions. Where trees are felled and removed, a minimum of the débris should be left on the ground to serve as a conductor of the flames, and all of it should be so disposed of that when the season of least danger arrives, the refuse may be burned without damage. These outlines indicate the importance of enforcing adequate supervision if the greatest benefit is to be derived from our forests; but, aside from any theoretical view of the subject of forest preservation, there is a feature of the forest reserve policy which often escapes attention, but which every bona fide miner must recognize and appreciate.

I refer to the prevention of illegitimate location of timber lands as mining claims. How many mining enterprises of great promise have been balked by such pactices? Every experienced lode miner knows instances where "stake locators" have claimed every acre of timber land within miles of a promising discovery, for no other purpose than to compel the owner of the legitimate mining claim to purchase a fraudulent one in order to secure the timber essential to the operation of his property. Many of these nefarious schemes have been defeated through the efforts of forest officers, and a more effective method of dealing with such blackmailers is being carefully worked out. Illustrations are not wanting to show that where opposition to the inclusion of certain tracts within forest reserves has resulted in the elimination of such tracts, and the land shark relieved from the vigilance that has prevented the carrying out of his plan, he at once makes application for patent to alleged mineral land and 
promptly secures absolute control of it. These speculative entries place the legitimate miner at the mercy of the unscrupulous holder of the title. One or two alternatives the miner must adopt: either to sell out and practically abandon his property, or else to pay an exorbitant price for the timber his tormentor controls. Usually it is the object of the speculator to force the former; sometimes the latter is sufficient to satisfy his greed. In either case rascality triumphs, and the man whom the Government would assist and encourage is victimized and his meritorious enterprise embarrassed or defeated. Further than this, in certain cases where formerly there was an abundant supply of timber available from the forest reserve, since eliminations have been made, residents find themselves unable to secure timber for domestic and other purposes without infringing the law; and it has been demonstrated that ordinarily where a tract of timber land in a mining region, once included in a forest reserve, has later been excluded from it, the honest miner and prospector not only had little to do with securing the elimination, but is now anxious to be again within the reserve; while the purely speculative individual, whose schemes were formerly circumvented by forest officers, and through whose efforts the eliminations were made, instead of being thwarted, may do whatever his sinister motives may permit.

It is commonly supposed that the conservation of the water supply and the maintenance of an equable flow in the streams of the country are of interest chiefly to the irrigationists; the placer miner in this connection is forgotten. But he is an important factor in the nation's prosperity. Without an adequate water supply, he cannot conduct his operations successfully, no matter whether his work be done with the primitive 
rock and the sluice box, or carried on with the most advanced dredging or hydraulic elevator machinery. Moreover, as shown by the history of placer mining in California, Montana, and other great gold-producing States, there is a diminishing supply of water in every mining locality. The barren hills, once clothed with timber, tell the tale of repeated fires and testify to the reduced water-storing capacity of the drainage basin involved. The methods of practical forestry as carried out in the administration of forest reserves make it easy for miners of all descriptions to secure adequate supplies of timber to satisfy their needs, and wherever a reserve has been established a sufficient length of time, the honest miner is ever the friend of the reserve system.

Like any other innovation, the introduction of forestry methods in a mining camp commonly arouses apprehension and antagonism; but experience cures the troubles. The conservative business administration of the forest reserve quickly results in the appreciation of the beneficent purposes of the reserve system, and converts enemies into friends. The honest prospector and the bona fide miner have nothing to fear from the forest reserve. As the forest policy shall be elaborated and adapted to the varying local conditions, the administration of the reserve will be improved, and the interests of the mining industry more enhanced. Examined from the viewpoint of experience, the relation of forest reserves to the mining industry appears so intimate, the success of one so directly interwoven with and dependent upon the continued prosperity of the other, that the possibility of real antagonism between them cannot be entertained. The forest reserve system has come as a benefactor of the mining industry, and when properly understood, it gives every incentive 
to miners to yield it their loyal support. American forestry and American mining should work hand in hand. Forest officers, laboring for the common good of all, reciprocally miners, as active and efficient friends, may coöperate in the achievement of noble objects alike beneficial to themselves and conducive to the public weal. 


\title{
THE VALUE OF FORESTRY TO COM- MERCIAL INTERESTS
}

\author{
BY \\ GEORGE H. MAXWELL
}

Executive Chairman, The National Irrigation Association

S OME, ten days ago a telegram reached me from the Governor of California asking if I could attend this Congress as a delegate from California. I replied that I could, and in due time received his appointment. I mention that merely in order that I may impress upon your minds that in the few words I have to say to you at this gathering, I speak as a delegate from and a citizen of California and a resident of that State, from the time of my birth until the last few years, which warrants me in speaking of forestry from the standpoint of a Western man.

I think it is only proper that I should further say to you that I also represent on this occasion the National Irrigation Association, an organization of between two and three thousand of the largest commercial and manufacturing firms in the United States, located chiefly in the Eastern States, and that I speak also from the standpoint of the Eastern commercial and manufacturing interests.

I think the mistake which those of us who are from the west make to-day, and always have made, is in looking upon this question of forestry in any sense as a sectional question. It is necessarily as much a national question as the maintenance of an army or the construction of a navy.

I wish I had the power by some telepathic process 
of impressing upon the mind of every man present the picture that is in my own mind as I stand here.

I crossed the Mississippi river on my way to the west a little over two years ago on a ferry boat on which was loaded a train of overland passenger cars, and as we crossed that great river opposite the city of New Orleans, during one of the greatest floods in years, the flood was almost up to the tops of the levees on both sides of the river. It was a serious question whether the city of New Orleans was not in danger; and as we landed on the west side of the river we looked down over the bank and saw the plantations way down below the level of the water, and exposed to overflow and destruction any moment that artificial barrier gave way. Before we had gone twentyfour hours further west the levee did break and one of those great crevasses was formed, and practically destroyed the crop for that season over a large area; though other localities and the city of New Orleans were saved by the diminished pressure of the flood on the adjacent levees.

As I stood on the boat and looked out over that great river, then at its highest flood stage, I realized the fact that from over more than one-third of the entire area of this nation, the water that falls upon it must escape to the ocean through that one gateway; and that as the years go by, year after year, we are destroying the grass and plowing up the prairies and stripping the trees and the brush and forests from the mountains so that the engineers can see that every flood plane gets a little bit higher than the last.

I could not help thinking to myself whether it might not be possible some day or other to awaken the people of the Mississippi valley to a realization of the fact that forestry is a problem extending from New Orleans 
to the Continental divide of the Rocky Mountains on the west, to Canada on the north, and to the crest of the Alleghenies on the east, where the Ohio river has its source. And if it is expected in the years to come to control that great flood by building the levees higher and higher, I have only to say to the people of the lower Mississippi valley, the sugar bowl of the continent, that the time will come when they cannot build them higher and the country will go back to a swamp and be as desolate as it is to-day where the St. Francis basin is covered with water through which you may look down and see the tops of the trees that once grew on dry land. How are you going to prevent that?

I say to you as a commercial proposition, if you look at it solely from that standpoint, as a proposition of cold, hard figures, that it is the duty of the national government to conserve that flood of water so that every drop of it can be used in the State where it falls before it finds its way into that great river and goes down to destroy the plantations. And that year by year the use of that water, if it were all used for power, for irrigation, for the navigation of the streams in the summer season (because the water would be in the streams then in the summer season), that it would more than double, more than treble, more than quadruple the productive power of more than one-third of the United States.

Isn't it worth doing?

Let us carry the picture in our minds a little farther up the river and look at Kansas City and that great flood that came so near destroying its business section that same winter. Look at the Ohio River flood in the Pittsburg vicinity that same winter. Look at the Allegheny Mountain region a year later. I came down from Harrisburg to Washington last spring 
when Congress was in session. The railroad track had been submerged and torn to pieces in many places by the flood, and the ice was banked up as high as the second story windows of the farmhouses to the left as we came down the river.

It is only within the last two weeks that I read an article in the New York papers to the effect that the cities of that Allegheny region were without water, the railroads were hauling water and the mines were shut down because the rivers were dry.

I ask, why is that? And I will answer the question for you. It is because we have gone over those hills and mountains with axe and fire and stripped the hillside and the mountain tops of the whole Allegheny region, and instead of having a natural forest cover, which is the greatest reservoir known to nature or to man, we have a surface which sheds water as fast as the floor of this hall would shed it if you stood it at an angle of 45 degrees.

There is no other question of as much interest to the commercial, manufacturing and transportation interests of the country, to say nothing of agriculture, as that one question, forestry.

It is not a western problem or an eastern problemit is a national problem.

When I appeal to you for this broad consideration of it, all that I ask is that you will project your minds across the ocean to the shores of the Mediterranean, to Palestine, to Persia, to the plains of Mesopotamia, and answer me this question:

Where is there a nation that has been desolated by war that has not been restored to fertility when it lived upon a land that was productive?

Where has there been a nation destroyed by the desert that has been restored or ever will be? 
Instead of talking about national protection by "army and navy," we should talk about national protection by "forest, arny, and navy."

I am in favor of an army commensurate with our needs. I am in favor of this nation having not the second best, but the greatest navy of any nation, but if we can afford to do that, we can afford to spend as much upon the preservation of our forests and the protection of our country from destruction by the desert as we can afford to spend for the protection of our frontiers from a foreign foe, or to carry our flag upon foreign seas.

This great problem of forestry is not alone a matter of sentiment. It is just as much a cold-blooded question of business. The speakers who preceded me have spoken upon the importance of forestry to mining. I have listened with much interest to their masterly discussions on the relation of forestry to mining, and it brought more forcibly than ever to my mind the conviction that the whole country and those engaged in all its industries are fast coming to recognize the importance of forestry. I regret that we cannot include the lower house of Congress. They do not seem to have yet waked up to it. I have read that the Japanese have been throwing 800 shells a day into Port Arthur, which have cost $\$ 1,000$ apiece. I think we could well afford to go to that expense with shells that were physically harmless to see whether we could not wake Congress up, by exploding that many such shells over the heads of the members of the House of Representatives.

I am not going to take up your time with any further dissertations upon the importance of forestry. But I want to offer some practical suggestions as to what we should do to get what we want done. I listened with 
the greatest interest and pleasure to the President's address yesterday, and one of his sentences struck me very forcibly. He said: "We want to change the hope of accomplishment to the knowledge of things done." If we are going to do that we must have a clear-cut idea of what we are going to do and of what we want Congress to do-so plain and clear that there is no possibility of any man being so stupid that he cannot understand it.

We have listened to these gentlemen here to-day telling of the necessities of the mining industries and of the injustice brought about by insufficient laws. There is a most simple way to get all the things done that they have recommended, and more, too. The first is to bring about a perfect understanding with a business bureau of the Government, if we can create such a bureau, and the way to do that is to pass the bill consolidating the forest reserves under the control of Mr. Gifford Pinchot.

And after you have done that and he has consulted with the lumberman and the miner and the farmer and understands what they want, then back him up and make your Congressman help to get it done.

There has been a good deal said here about tree planting, and I want to speak of the importance of tree planting to California. The water that comes from the Sierra. Madre and San Bernardino Mountains produces annually $\$ 20,000,000$ worth of fruit and other products of the irrigated farms to exchange with the manufacturers of the east for the products of their factories. The forests of those mountains have been neglected, thousands of acres have been burnt over and destroyed. One citizen of that State has interested himself prominently in tree planting. I refer to $\mathrm{Mr}$. Lukens. He deserves to be mentioned by name. He 
has given generously of his own time and his own money and the Government has helped in a niggardly way. There is now a nursery of trees ready to be planted upon the hillsides of those burnt wastes and we cannot get a few thousand dollars' appropriation to plant the trees.

Now why is it that such a condition as that can exist? Why is it? I will tell you the reason. It is because we have "Watch Dogs of the Treasury" in Congress who object to large appropriations for forestry. They can see the vast importance of huge contracts for armor plate and for building fortifications, but they care nothing about protecting our country from destruction by the desert.

Let us look at the business end of that proposition. There are other things besides bees that have business ends. For a number of years the President of the United States, the Secretary of the Interior and the Commissioner of the General Land Office have been trying to impress upon Congress, without success, the necessity of repealing the Timber and Stone act. I want to give the exact facts. The President, in December, I902, more than two years ago, called the attention of Congress in the strongest possible language to the necessity of doing something to stop the frauds and depredations upon the public domain under the Timber and Stone Act. The Secretary of the Interior reiterated his demand, and specifically urged Congress to repeal that law.

The secretary said in his annual report more than two years ago:

"The Timber and Stone Act will, if not repealed or radically amended, result ultimately in the complete destruction of the timber on the unappropriated and unreserved public lands.". 
I find these words in the report of the Senate Committee on the Public Lands, and the date is February 19, 1903:

"It can be plainly seen that all the valuable timber lands of the United States will be owned by speculators within three years if the opportunity to acquire them at $\$ 2.50$ an acre is continued."

That was February 19, I903.

It is now pretty close to February I9, I905, and one year from that date the three years will be exhausted, all the timber land will be gone, according to this official statement.

Has the bill been repealed? No! Has the House of Representatives done anything to stop this shameful waste of the public property under the Timber and Stone Act? No!

They have done nothing whatever to stop the abuses and frauds constantly being committed under that act.

Again, the following year the President in his message to Congress made.substantially the same recommendation. They were reiterated by the Secretary of the Interior. The Senate Committee on Public Lands recommended a bill to repeal the Timber and Stone Act and the Senate passed the bill in the last session of Congress.

It went to the Public Lands Committee of the House of Representatives.

Mr. T. B. Walker appeared before that committee and waved his magic wand and they gave two votes for the repeal of the bill out of eighteen members of the committee. Two votes! And the bill is lying there in that committee yet.

In this session of Congress, without waiting for anything, or for anybody to do anything, they passed a resolution in the Public Lands Committee of the 
House continuing this whole subject over until the next session of Congress.

The next session of Congress will convene at a time within two months of the expiration of the three years within which the Senate committee told Congress that all the timber land would be gone unless they got action.

T. B. Walker is one of those astute business men who has taken full advantage of the idiocy and incompetency of the men who have framed our timber laws in the past to amass a fortune for himself in timberlands. $\mathrm{He}$ is reputed to be the largest individual owner of timberland in the United States. I do not charge Mr. Walker with having committed any fraud himself, and the fact that he has acquired a fortune running into millions by the utilization of laws which enabled him to absorb the public forests into his private ownership is one of the severest criticisms that can be made of the law I am talking about.

Now it is a question of money. From the standpoint of Congress this great nation has not enough money to plant those few trees we have in the nursery, to protect the forests of Southern California and the water supply of its farms and of the cities of Los Angeles and Pasadena.

In the two years that have expired since the President has called the attention of Congress to that timber and stone law there has been located under the Timber and Stone Act over 3,000,000 acres of timberland, the greater part of it the magnificent timber of the Northwest, which, according to the report of the Secretary of the Interior and the Commissioner of the General Land Office, is worth anywhere from $\$ 20$ to $\$ 100$ an acre, for the mere value of the stumpage, to say nothing of the young timber or the land itself. 
In other words, as a result of the deliberate delay of the Public Lands Committee of the House, instead of having the value of the stumpage from that 3,000,ooo acres of timber in the national treasury, we have parted with the timber and the land and the young growth and everything for $\$ 2.50$ an acre.

Taking the value of that timber at what the stumpage actually sold for upon some of the Government land in Minnesota, \$15.06 an acre, the Government has lost $\$ 40,000,000$ by that proceeding. But the stumpage on the $3,000,000$ acres located during the last two years was much more valuable than that. And if the Government had managed its timberland business as any business man or any man of sense would have managed it, we might just as well as not have realized $\$ 70,000$,oo from that stumpage, and have had our young forest trees planted in southern California and the surplus left over.

We are told that there is going to be a deficit this year in the revenues of the United States of $\$ 22,000$,000. If we had not thrown away that $\$ 70,000,000$ we could have covered that deficit at least twice over and still have had money left in the treasury. In other words, the Public Lands Committee of the House has thrown away over $\$ 70,000,000$ of the people's money in the last two years. If we should put this total loss at only $\$ 50,000,000$ for the two years it has amounted to over $\$ 2,000,000$ a month, or about $\$ 70,000$ a day.

Now suppose some enterprising and ingenious person had succeeded in tunnelling under the United States treasury and cut a hole into the vaults and was carrying off $\$ 70,000$ a day. Don't you suppose we could get the people of the United States to wake up the Public Lands Committee if it required some action by them to stop the stealing? That is exactly what is 
going on; for if the House Public Lands Committee does nothing in this session of Congress (and they have already voted to do nothing), the loss to this country of $\$ 70,000$ a day- $\$ 2,000,000$ a month $-\$ 25,000,000$ a year, and it is much more than that-will go right along and continue until all the timberland of our Government has been stolen. That will be a little over a year, according to the report of the Senate Public Lands Committee. And after the land is all gone-after the horse has been stolen, the House Public Lands Committee will awaken from their Rip Van Winkle slumbers and close the stable door with a bang.

Now who has got this vast sum of money that has been lost to the people and the Government? Some very enterprising gentlemen of the West have made it, who are taking advantage of this law to their own personal profit and we are very seriously told that the West does not want the repeal of the Timber and Stone Act. Mr. Lacey, of Iowa, the chairman of the committee, says that "the boys on the committee do not want the law repealed." Let me illustrate this condition in the West. Suppose we had a law by which $\$ 70,000$ a day or $\$ 2,000,000$ a month was being paid to Tammany Hall from the national treasury, to be divided among the members of that organization and expended by them as each of them in his judgment should deem most meet and proper for the promotion of good government in New York City.

Don't you suppose that Tammany Hall would be opposed to the repeal of that law?

You might apply the same idea with reference to this question of the West. But it is a more serious matter than that. There are men in Congress who will deliberately stand up and say that this law should not and shall not be repealed. 
There was one thing the President said yesterday that $I$ as a Western man cannot fully endorse. He said, in substance, that if the forests of the West are to be saved, the people of the West must save them. I say to you that if the forests of Oregon and Idaho and Washington and Montana and Colorado are not to be saved unless the people of those States save them, they will never be saved. If they are to be saved at all, it will be by Theodore Roosevelt and the people of the East.

I want right here to express the obligations we owe to President Roosevelt for going into the West and making forest reserves which have saved thousands upon thousands of acres of forests of the West that never would have been saved had it not been for Theodore Roosevelt.

It is also a matter of history that the forest policy which now exists was forced upon the West against its will by Grover Cleveland by executive order.

You find such Congressmen as Mr. French, from Idaho, arguing against the repeal of the Timber and Stone Act and making such arguments as I have heard him make, that it was a good thing for the Government to sell a man for $\$ 400$ a quarter section of land, which he could turn around and sell for $\$ 4,000-$ that it induced people to go to Idaho and gave them capital to start in business. Don't you suppose that if you offered a bonus of $\$ 3,600$ in cash out of the national treasury to every many who would come to Washington to live that you could get more people to reside here and raise the value of real estate in the city? That is the proposition from the Idaho standpoint as applied to the city of Washington.

Before I close I wish to specify some definite and specific things which should be done: 
First. Repeal the Timber and Stone Act.

Second. Pass the consolidation bill putting the Government forests under the management of the Bureau of Forestry.

Third. Provide by national legislation that every acre of agricultural land that can be reclaimed under the national irrigation system must be saved for the homemaker who will go there and make a home upon it.

In that way you can break up the timber combination, and in that way only; because the land thieves of North Dakota, under the Commutation Clause-the land thieves of Montana under the Desert Land Actthe land thieves, under the Timber and Stone Actwell, perhaps I might be permitted to mention Oregon in this connection-are working together. You will have to explode some of those Japanese shells among them to break up the combination.

The situation in Oregon reminds me of a saying of Mayor Henry, of the city of Oakland, out in California, twenty or more years ago. There had been a good deal of rottenness in the municipal affairs. The newlyelected mayor was something of a rival of Mrs. Partington. His knowledge of Greek names were a little mixed, and in his inaugural address he declared with great energy, "Gentlemen, I am going to clean out the Oregon stables!"

I really think we are going to get the Oregon stables cleaned out.

To show you why we cannot depend upon Congressmen from the timber State of the West to correct this enormous evil, a year ago both Oregon Senators and both Representatives from Oregon were bitterly opposed to any change in the land laws. Representatives Hermann and Williamson both went before the çom- 
mittee and protested against any change. Mr. Hermann was before the committee. At that exact moment the Oregon grand jury was in session in the city of Portland, composed of men drawn by lot from all over the State, and that grand jury urged the repeal of all those laws-the Timber and Stone Act, the Desert Land Act, and the Commutation Clause, and sent a memorial to the Public Lands Commission to that effect. Now the grand jury has had some business with Mr. Hermann since that time.

I understand that $\mathrm{Mr}$. Williamson is not here, and I do not know where he is. I did see an article in an Oregon paper charging that he put up the money himself for some fellow to buy a lot of worthless school land, and then they tried to get it into a forest reserve and failed and Williamson lost his money.

I am lifting the sheet off the corpse a little, but.I don't think it will do any harm. If you don't have these cold, hard facts impressed upon you by somebody you are not going to accomplish anything.

If you want to do something, go ahead and talk to your member of Congress and get him to help to get the House of Representatives to carry the public lands legislation right straight over the heads of the committee.

They passed one land bill at the last session of Congress, a bill throwing away thousands and hundreds of thousands of acres of lands, in tracts of 640 acres, in western Nebraska, which should have been retained and trees planted on it to be used in the mines of South Dakota, and of the whole Rocky Mountain region. Nebraska sold its birthright for a mess of pottage when it allowed the Kinkaid bill to become a law. The whole scheme for 640-acre homesteads is a rank deception and offers a premium for fraud. 
There are a number of other things that $I$ have in my mind to suggest that ought to be done:

One is to pass the Appalachian Forest Reserve bill, which is ready to be passed.

Another is to stop now and for all time all exchanges of lands in forest reserves for other lands. If the Government needs any such lands let it buy them and pay for them their fair value and no more. All lieu land scrip should be called in and cancelled and no more ever issued under any circumstances. The forest lieu land exchange law should be repealed.

And if this session of Congress adjourns without the bill being passed by the House, which has passed the Senate, repealing the Timber and Stone Act, every member of the Public Lands Committee, who voted for delay, ought to be held up to popular obloquy and whipped at the cart's tail with a lash that would make them feel the full weight of an outraged national public sentiment.

They are not liable to punishment criminally, but they are morally responsible for every fraud committed under the Timber and Stone Act since they shelved the bill passed by the Senate in the last session of Congress to repeal it.

But it is not enough merely to repeal the Timber and Stone Act. Every acre of public forest lands or brush or woodlands which conserve a water supply should be at once embraced in permanent forest reserves, the title to be always retained by the national government, and the stumpage only of matured timber to be sold.

The whole great plains region should be studied and developed as a vast area which can be transformed from a semi-arid region to one of great fertility and more humid climate by the planting of immense areas, 
hundreds of thousands of acres, of new forests by the national government on the wide level prairies and bare, rolling foot-hills which are now supposed to be among the waste places of the land and only fit for grazing ground for a few stray cattle and sheep.

It is the vast possibilities of forest planting and timber production in this region that makes it almost a crime against future generations to part with the land in its present condition to stockmen under such a scheme as the Kinkaid bill for the creation of large grazing estates in private ownership.

The mining and transportation interests, more immediately than any other, ought to oppose this 640-acre homestead idea anywhere in the great plains or Rocky Mountain States, and help to inaugurate a great national policy of planting new forests, not only to furnish wood and timber for the mines, and railroad ties and timber for railroad construction and repair, but to conserve and increase the rainfall, regulate the flow of the rivers, stop floods and furnish water for irrigation.

In all those Western States, the State has the power to form districts for local public improvements, such as irrigation districts, sanitary districts, drainage districts, or levee districts, and I, for one, do not believe that it is the right policy that the national government should assume the burden of protecting from fire forests now owned by men who have gotten them from the Government for one-tenth of their value. The State and nation should coöperate to form forestry districts and have assessments levied on all private lands in the district, and every acre, whether in public or private ownership, should contribute its proportion to the cost of preserving it from fire.

There is one more thing I am going to urge as a 
mere matter of personal opinion. In making the suggestion I do not speak for California or for the $\mathrm{Na}$ tional Irrigation Association, but for myself alone. I have been all my life a republican, and in my earlier years advocated the republican doctrine of a tariff for protection in many political campaigns in my native State of California from the Oregon line to Mexico; but because I believe in preserving our industries and not in destroying them, I believe that in order to preserve the forest industries of this nation, we should repeal every tariff law imposing a tariff upon the products of the forests whether timber or wood or wood pulp, at any rate for a limited number of years, and until we have planted forests enongh to annually harvest from our own forests all the wood and timber we use in any one year. 


\title{
STATISTICAL RELATION BETWEEN FORESTRY AND MINING
}

\author{
(Impromptu Address) \\ BY \\ DR. DAVID T. DAY \\ United States Geological Survey
}

T $\mathrm{HE}$ relations of the mining industry to timber supplies and the consequently necessary forest culture, have been stated many times and many ways so that the views on this subject are not novel, neither are they clear. They are not clear because of fragmentary statements made largely from very different viewpoints by miners and by foresters. Further, during the few years in which this subject has been discussed the relations have been changing.

The mining company is recognized as a good customer by the lumberman and by the preserver of forests he is recognized as a wanton destroyer and a deadly foe.

The miner has established his reputation as a good customer to the lumberman and he is daily becoming a better customer. This is because mine timber seldom costs more than ro per cent. of the cost of the ore, and the large consumers want the best and can easily afford to pay good prices for it. He can afford to send farther for his supply than most other customers. $\mathrm{He}$ is much in the same category as the railroad, except that frequently poor timber will last longer than it needs to last in a mine, and this is never the case with ties. The miner outran the railroads as a timber consumer, for it was stated here yesterday that a forest reserve of half a million acres would (properly managed) furnish the United States with ties. I doubt 
if $10,000,000$ acres would suffice to keep the miners going.

We have no accurate knowledge of the amount of timber used in a year in the mines. But we do know that it requires about a cubic foot for each ton of anthracite, say $70,000,000$ cubic feet per year, somewhat less for each ton of bituminous, say $250,000,000$ cubic feet yearly. Iron ore needs at least $20,000,000$ feet, precious metal mining needs a cubic foot for each cube of gold, such as I have here, or say $75,000,000$ cubic feet, or say $400,000,000$ cubic feet a year for the whole mining industry.

As a deadly foe to the forester the reputation of the miner is losing his former picturesque position, as fast as many of the sensational stories of the miner's depravity cease to represent present conditions, and pass with old pioneer conditions into the legends of old days.

Foremost among these dear old classic legends is that of the prospector who burns off the forest to get rid of the undergrowth so he can more easily discover his hidden treasure. Of course, prospectors include every sort of man, even the kind so foolish as to resort to such methods, but such men are disclaimed by the profession and in no way characterize the prospectors. I doubt if any species of tramp ever traverses the forest who uses such thoroughly trained care in extinguishing every spark of fire he kindles as the genuine life-time prospector. $\mathrm{He}$ is accustomed to use every mark of changing vegetation to guide him in looking for changes in rock and soil conditions. He wants trees for landmarks if nothing more, and the only places where vegetation is so dense that burning off would compensate for the loss of guiding marks is in regions so wet that you could not build a forest fire with kerosene. 
The main reason why the miner is no longer a foe to forest protection, is on account of two influences at work upon him. First, the missionary work of the foresters has converted him from wantonness in cutting timber. The mines are growing larger and less of them, there are fewer mining superintendents to educate and they are men of high grade. But most significant is a changing condition in mining practice by which the mining company falls into the same category as the lumberman as regards forestry. The change is this, the mining company cuts a continually lessening percentage of its own timber and buys correspondingly more from a distance. This increased attention to their own specialty of mining and buying their supplies of all kinds, especially their timber, from outside agencies is as marked a development as any other kind of industrial specialization and is as greatly aided by increased facilities for transporting supplies from considerable distances.

The timber merchant will in the future stand between the forester and the mining company. This is fortunate, especially in one way. There is no more difficult task than trying to educate the average mining man into any attribute of patience such as planting trees for his successor to use. His whole training is in the line of getting out all his ore with the greatest possible speedto work out the deposit and go somewhere else.

Frankly, the mining company often has been and occasionally still may be, worse than the man who skins a country, the miner disembowels it and leaves an absolute desert above and below. If the miner can be taught by forestry methods something of conservatism in rushing his mineral to market, the whole country will be better off.

Further, it seems that as the friends of good govern- 
ment all citizens may take another lesson from the Government's attitude to the public forest lands, and just as the general people's valuable forest assets are being set apart for careful husbandry in forest reserves, so the citizens may well insist that our public mineral lands have ceased to serve a useful purpose as a bait to immigration. It is no longer necessary nor good public policy for the Government to give away practically free to the mine promoter valuable coal, oil, gas lands, and also lands where valuable metalliferous deposits may be reasonably looked for.

The prospector is no longer greatly aided by such laws. He can be helped much more by governmental coöperation and joint ownership. It seems timely that the same wise regulations adopted for the sale and lease of lands belonging to the Indians should be applied to lands belonging to the people as a whole, and it is to be hoped that Death Valley, many regions in eastern Utah, in the Rocky Mountain regions, may soon become Government mineral reserves. 


\section{PART VII}

NATIONAL AND STATE FOREST POLICY 



\title{
THE WORK OF THE BUREAU OF FORESTRY
}

\author{
BY \\ OVERTON W. PRICE
}

Associate Forester, United States Department of Agriculture

I N THIS opportunity to say a word to you about the work of the Bureau of Forestry, I want to go a little further than merely to catalogue its present achievement. Because it seems to me that your chief interest lies not merely in what the Bureau has already done. It lies rather in the power of the Bureau for future accomplishment, which its organization and its point of view make possible. For although in the light of its results, the achievement of the Bureau is tangible and far-reaching, it marks only a small beginning, in the light of the work not yet done. And since the great bulk of the forest work is ahead of us, I want particularly to indicate how the policy of the Bureau enables it to assist in the practical solution of the forest problems still before the great industries represented here.

Six years ago the reorganization of the Bureau took place. At that time, the foundation of an individual, a state, and a national forest policy had in part been laid, but its practical application had scarcely begun. It was the attitude of the Division then, as it is the attitude of the Bureau now, that the printing press and the lecture room are not in themselves adequate to get forestry generally into effect in this country; that the urgent need is practical field work with which to meet great forest problems on their own ground, and that the results of this field work, the practical solution of 
these forest problems, should be published and distributed for the benefit of all-therein, as the Bureau sees it, lies its province, its duty, and its great opportunity for usefulness. Under this policy, the Division became a Bureau. Above all, it is the policy under which it has been able to attack effectively the forest problem in all its parts.

Since its reorganization, the Bureau of Forestry has directed its earnest and constant endeavor along these four main lines:

First. It coöperates by practical assistance and advice in forest work which not only benefits individual coöperators but is of help to many others.

Second. It attacks, independently, those urgent forest problems whose solution by private enterprise is impossible, and thus becomes a national duty.

Third. It renders all assistance within its power in the best use of the federal forest lands; and finally,

Fourth. It publishes and distributes the results of its investigations for the benefit of all.

The coopperative work of the Bureau began in October, I898, with the offer of assistance to private owners in the handling of their own lands. From this beginning it has broadened as the direct result of an insistent demand, until it now offers assistance not only in the preparation of working plans, but also in tree-planting, either for commercial purposes or for protection, and in discovering the most conservative and profitable methods for the use of the products of the forest. The coöperative state forest studies, which offer a great and increasing field for usefulness, have also grown out of the policy of the Bureau's coöperation with private owners.

The coöperative work in all its branches has had two important and tangible results : Not only has it brought 
about the use of new and better methods on the ground, but, above and beyond the benefit to the individual coöperator, this work, through the publication of its results, has been a far-reaching influence in furthering that understanding of the purpose and methods of forestry, without which its general application is impossible. Thus, the results of the coopperative work cannot be measured by the great areas of forest land now under management as the result of working plans prepared by the Bureau, or the three hundred and thirty-four planting plans which the Bureau has prepared for lands in fifty-two states and territories. In its coöperation with railroads, the Bureau, at an expense truly insignificant in comparison with the value of the results, has developed facts regarding the preservative treatment of ties and construction timbers and the profitable use of woods of inferior kinds whose value is beyond estimate both to the great transportation systems themselves and in its decrease in the drain upon our forests. In its coöperative state forest studies the Bureau's work has in each instance had a definite and tangible result in preparing a solid basis for a comprehensive state forest policy. But each piece of coöperative work, whether with the individual, the corporation, or the state; whether in tree-planting, in working plans, or in studies of forest products, is justified not merely by the direct benefit to the coöperator, but by the acquisition of knowledge for the common good, in which its widest usefulness lies.

To the statement that this coöperative work, valuable as its results may be, falls properly not within the sphere of the Government, but to the private forester, the answer is that the Bureau of Forestry took up this work only because no private foresters were available to do it. It is work which the Bureau has from the 
beginning recognized as purely temporary in its character. To postpone it until the private forester was in the field would have meant that the better use of our forests would have been for a long time delayed. The area in woodlots and timber tracts in this country is approximately five hundred million acres. It is from them that our future timber supply must chiefly come. And the inauguration of better methods in their management is thus a national duty until the private forester is present in sufficient numbers to carry the work. When that time comes, the Bureau will step aside. As a matter of fact, the Bureau has by its coöperative work not only instituted better methods in the use of the forest, but it has hastened, by making clear the business advantages of these methods, the growth of forestry as a commercial enterprise; and hence the employment of the private forester. And right there it is significant that, with very few exceptions, the private foresters employed in this country to-day owe their work either to the recommendation of the Bureau of Forestry or as the direct result of its coöperative work.

The second line of endeavor which it is the duty of the Bureau of Forestry to follow is that of independent investigation. This embraces the solution of those urgent forest problems which are beyond the scope, the means, or the trained knowledge of the individual, but which confront him, and through him materially affect the development of the great industries. Just as it is the duty of the Government through the United States Geological Survey to map this country, so is it also the duty of the Government through the Bureau of Forestry to put in the hands of the people knowledge essential to the best use of the forest, and as unobtainable through private enterprise only as are the maps. 
The Bureau of Plant Industry, of Animal Industry, of Soils-the scientific work of the Government throughout-conducts studies national in their importance whose solution is beyond the power of the individual. In exactly the same way, the Bureau of Forestry attacks those forest problems necessary to the permanent prosperity of all industries dependent upon wood and water. Under this policy the Bureau is conducting studies of commercial trees, since the published results of these studies serve as a basis for working plans, as a source of useful information to lumbermen, and as a valuable contribution to our knowledge of American forests. It is conducting independent studies of forest fires as a means for the solution of the urgent national problems which they present, both in the form of legislation which will be effective against forest fires and in methods for their prevention and control.

In its timber tests the Bureau of Forestry is supplying an urgent need of fuller technical knowledge of the strength of our commercial timbers, and is thus paving the way for economy in their use as well as in the woods.

In the preparation of forest yield and volume tables the Bureau is laying the foundation for conservative forest management in all parts of this country. In its forest maps, its dendrological studies, and in many other ways, it is equipping the great industries dependent upon the forest with knowledge essential to their development.

In the third line of its endeavor, the rendering of all assistance within its power in the best use of the Government forest lands, the Bureau is to the full extent of the province which legislation has entrusted to it giving assistance and advice in the management not only of the national reserves, but also of Indian 
and military reservations. Briefly outlined, this assistance has been as follows:

On December 7, I899, the Secretary of the Interior requested the Secretary of Agriculture for advice upon technical questions envolved in the administration of the reserves. The work of the Bureau of Forestry under this request has increased steadily in volume and scope, until at present practically all technical questions involved in the administration of the reserves are referred to it.

During the past two years practically all of the recommendations for new forest reserves and changes in the boundaries of existing forest reserves either originated with or were submitted directly by the Bureau of Forestry. Since it took up this line of work the Bureau has examined 130 separate areas proposed as forest reserves or as additions to existing reserves.

Regulations for grazing recommended by the Bureau are now in effect on two forest reserves in Utah and on four forest reserves in Arizona.

Six members of the Bureau were loaned to the forestry division of the General Land Office for periods of from one year to fourteen months (1902-1903). One of these members was chief of that division, two were inspectors, and two were head rangers.

Under the request of the Secretary of the Interior, studies have been made of several Indian reservations, and recommendations submitted for their forest management. The Bureau has also prepared detailed working plans for the Prescott, Black Hills, Big Horn, and Priest River forest reserves.

To sum up, the principles and practice recommended by the Burean to govern the administration of the national forest reserves have been approved by the 
Department of the Interior. The Bureau is now the recognized source of information upon the suitability of lands for forest reserves or of changes in the boundaries of existing reserves, for working plans for the management of the reserves, and for special reports upon grazing and other matters involved in their administration. In no case has the Bureau mixed in the details of reserve management. It has dealt exclusively with matters of policy.

In its work under the Morris bill the Bureau has proved that conservative lumbering pays in the pine region of northern Minnesota. It was charged with drawing up the regulations for conservative lumbering and with their enforcement upon lands which, after they have been lumbered; will constitute the Minnesota National Forest Reserve. The result has proved that the Bureau of Forestry can institute and conduct successfully large administrative duties in forest management.

In the fourth branch of its work, the publication of the results of its investigations for the benefit of all, the Bureau has distributed well on toward $2,000,000$ copies of its bulletins, circulars, and reports. I do not wish to inflict too much statistical information regarding publications upon you. But the distribution of publications is in large measure a test of the Bureau's usefulness, and the demand for them a proof of the appreciation of its work. And I want to give you enough facts to show, both that the publications are going out and that they are being read and used. Although the regular editions have been largely increased in order to meet the demand, no less than seventy-seven reprints have been required to satisfy it. A notable example of the scope of this demand is The Primer of Forestry, of which the first edition of 35,000 
was authorized by congressional action. Two editions of I0,000 each have since been printed, and since they, too, proved insufficient, a Farmers' Bulletin edition became necessary. Of this, 170,000, in eight editions, have been printed, making the total issue of the Primer to the present time 225,000 copies. Another instance is The Woodman's Handbook, a compilation of log scales and rules for forest measurements. The first edition of 15,000 was not off the press before the necessity for an additional supply was realized, and before the demand began to slacken, 25,000 copies, in three editions, were printed. The circulars giving the Bureau's offers of coöperation have passed through the press sixteen times in all, with a total issue of 123,000 .

To sum up, the Bureau is not only the direct and prevailing force behind the forest movement in this country, but it is furthering the application of those new and better methods on the ground without which the broadest, the most enlightened forest policy will utterly fail. It has, in my judgment, reached its present achievement, and it possesses its power of future achievement, as the direct result not only of an adequate organization and a comprehensive point of view, but above all because it keeps the practical aspect of its work constantly before it; because its policy is not one of arbitrary interference, but to bring about a relation between the forest and the interests dependent upon it which develops the highest usefulness and the highest permanent profit from them both.

One of the most gratifying features of the work of the Bureau, full of promise for its further usefulness, is, that in spite of the overwhelming demands upon it and of the utter impossibility, with the men and the money at its disposal, to meet all these demands, the technical standard of its work has grown steadily 
higher. The Bureau has fallen into no rut of routine in field work. Its methods in the field and in the office as well are thus showing year by year improvement which corresponds directly with the added experience of its men and the added funds at its disposal. The net result is a constant gain in effectiveness.

I have said very little about the past achievement of the Bureau because you have that in its bulletins, in its reports, and you find it in the woods on the ground. But unless I have entirely failed, the points I hope I have made clear are these: that the policy of the Bureau is to help every man in the use of the forest or of its products; that the Bureau stands ready to take up with you the solution of the forest problem confronting you, whatever it may be, and to take it up not academically, not theoretically, but practically, with due regard not only for the preservation of the forest but for the business advantage of the interests dependent upon it. That point of view has alone made the present achievement of the Bureau possible. It is a guarantee of still wider usefulness in the future, because it means that you and the Bureau can begin the larger work ahead, can face new forest problems as they come, not singly, as a purely governmental enterprise on the one side, or by private endeavor on the other, but together, in active and effective accord on the same ground. 


\title{
WORK OF THE GEOLOGICAL SURVEY IN MAPPING THE RESERVES
}

\author{
BY \\ CHARLES D. WALCOTT
}

Director of the United States Geological Survey

I HAVE been asked many times during the last seven years how it came about that the Geological. Survey was taking part in matters pertaining to the Government forest reserves; and I am glad to have the opportunity to give to this notable Congress some of the reasons for the activity of the Survey in this direction, and to record what has been done by it in surveying and examining the reserves.

Let me first speak very briefly of the influences and events that led to the Survey's taking up the work assigned to it by the Congress of the United States. Not many years ago one of our leading foresters said that, apparently; the forest policy of the Government had been to get rid of the land and that of the people to get rid of the timber; but within the last decade the country has awakened to a realization of the vast importance of its woodlands. Perhaps most influential in this awakening were the American Forestry Association and the Division of Forestry of the Department of Agriculture, under the leadership of Dr. Bernhard E. Fernow. From these organizations there came many reports, essays, and lectures on the subject, and 
these had a strong influence in creating the public sentiment that at last manifested itself in the passage, on March 3, I89I, of an act granting authority to the President to set aside as public reservations public lands bearing forests, wholly or in part covered with timber or undergrowth. (Stat. L., vol. 26, p. I IO3, sec. 24.) Under this act seventeen forest reserves were established prior to September 28, I893, aggregating in area $17,564,800$ acres.

The establishment of these reserves did not excite any special approval or disapproval of the policy, except as some local interest was affected favorably or unfavorably, In the latter case, little attention was given the matter by the parties directly concerned, for there was no real protection of the reserves by patrol, and the cutting of timber and the destruction by fires went on as before. But by executive proclamations of February 22, 1897, based upon recommendations of the Forestry Commission of the National Academy of Sciences, there were established thirteen additional forest reserves, containing an aggregate of 2I,379,840 acres. This action was followed by strong opposition to the policy, especially in the Northwestern States, in which many of the reserves were situated.

In the letter recommending the establishment of the forest reserves the Forestry Commission stated, in effect, that it had purposely recommended very large reserves in order to create a public sentiment which would cause Congress to enact laws securing the proper administration of the reserves. The result of establishing the reserves more than met the anticipations of the commission that legislation would follow, owing to the pressure of the people on their representatives in Congress. The first storm of protest came mainly from South Dakota, Wyoming, Montana, 
and Washington. Early in March, Congress inserted in the Sundry Civil Bill an amendment revoking the forest-reserve proclamations of February 22, 1897, and repealing the authority for setting aside public forested lands as reserves; but the bill failed, because President Cleveland did not sign it; and when the new Congress assembled on March 15, 1897, the agitation against the reserves was resumed.

My predecessor, Major J. W, Powell, was much interested in the forests of the country, but did not take an active part in shaping the policy of the Government control or administration of forest lands. I had kept in touch with the general movement for the preservation of the forests, and with the commission of the National Academy of Sciences, of which Mr. Gifford Pinchot was secretary; also with the members of Congress who were especially interested in the commission's recommendations, and knew the sentiment these recommendations had developed. After the attack on the policy of forest reserves in the spring of 1897, I found that the National Academy commission could not take further action, and that nothing was being done by the forestry officers of the Government toward urging constructive legislation and combating the movement to repeal the law and return the forest reserves to the open public domain. After consultation with a number of senators from the Western States, I drew up, at the suggestion of Senator Pettigrew, of South Dakota, an amendment providing for the survey and administration of the forest reserves. The administrative features of the amendment were based upon previously proposed but not enacted legislation, and upon the recommendations of the commission of the National Academy of Sciences, modified to meet conditions in April, I897. The preliminary draft 
was then thoroughly examined by and discussed with Senator Pettigrew.* The amendment met with the approval of the Secretary of the Interior and of the President, and it was introduced in the Senate in a modified form by Senator Pettigrew on April 6, 1897, as a proposed amendment to the Sundry Civil Bill and was referred to the Committee on Appropriations. On April 8, 1897, Senator Pettigrew offered the amendment as originally prepared, and it was referred to the Com-

Charless D. Walcotrt, Esso.

* Hotel Victoria, New York Citr, January $I I, 1905$.

U. S. Geological Survey,

My Dear Sir:

Washington, D. C.

Your letter of January Ist has just reached me, too late, I suppose, for me to be of use to you in connection with the Forestry Congress. I think your account of the amendment to the Sundry Civil Bill with regard to the administration of the forests of the United States is substantially correct. I was the author of the legislation of I89I, authorizing the President to set apart forest reservations out of the public domain, and therefore always in favor of a policy which should protect these forests and perpetuate them, so that they would grow better year by year.

I studied with great care Napoleon's method for administering the forests of France: I also investigated the English policy in India, and the policy pursued by the Austrian Government, and I reviewed and slightly amended the suggestions which you made to what is now the existing law. I remember my colleague, Senator Moody, made such modifications and amendments as it seemed to me were not advisable, and that you and I together went over the manuscript and struck them out; that the result of our joint labor was the law as it now stands, under which the forests are administered.

For my part I should be pleased if all the forest lands, and all the other lands now owned by the Government of the United States, were withdrawn from sale and were administered by the Government, so that the title would remain forever in the Government for the benefit of the people of the United States.

Very truly yours, (Signed) R. F. PETTIGREW. 
mittee on Forest Reserves and the Protection of Game. The amendment of April 8 was reported back to the Senate by the latter committee with favorable recommendation.

When the Sundry Civil Bill was under consideration in the Senate on May 5, 1897, Mr. Pettigrew offered the amendment of April 8 as an amendment to an appropriation for the Geological Survey. (Congressional Record, vol. 30, p. 899.) After discussion in the Senate, it was accepted on May 6 (Congressional Record, p. 908-925) and soon after went to the Conference Committee of the Senate and House on the Sundry Civil Bill, where minor amendments were made to the provision for the administration of the forest reserves. On May 27 the Senate agreed to the conference report (Congressional Record, p. 1278I285), and on June I the House of Representatives accepted it. (Congressional Record, p. I397-I40r.) On June 4 the President approved the Sundry Civil Bill, and thus completed the legislation providing for the survey and administration of the forest reserves of the United States.

The period from March 4, when President Cleveland killed the scheme to revoke all forest reserve proclamations, to June 4, when President McKinley signed the act containing the forest reserve legislation, was a strenuous one for those directly interested in the protection and utilization of the public forests. Conferences were held at the office of the Secretary of the Interior, Cornelius N. Bliss, and many hours of anxious suspense followed the formulation of a plan that met with the approbation of the department and of the members of Congress from the western states directly affected by the forest reserve policy. The new law was not ideal, but it was all that could be obtained under the conditions then existing. 


\section{AMERICAN FOREST CONGRESS}

The administration of the forest reserves was placed in charge of Commissioner Binger Hermann, of the General Land Office, and continued in his charge until 1903, when Commissioner Richards succeeded him. The surveys and examinations of the reserves were, by the act, placed under the Geological Survey.

The survey of the reserves was begun in 1897 and has continued to the present time. The results, briefly stated, are as follows:

Five reserves have been completely mapped-the Black Hills, South Dakota-Wyoming; Bighorn, Wyoming; Teton, Wyoming (now a part of the Yellowstone Reserve); Santa Rita and Prescott, Arizona; and work has been commenced in twenty-nine other reserves.

The boundary lines of the Black Hills, Bighorn, Aquarius, Logan, and Pocatello reserves have been completely surveyed and marked with iron posts; also parts of the Lewis and Clarke, Washington, Mount Ranier, Madison and Payson, and Black Mesa and Mount Graham reserves have been surveyed, comprising 1,328 miles of boundary line. In connection with this, there have been surveyed I,976 miles of standard and subdivision lines of various kinds, for which notes and plats have been filed in the General Land Office, as required by law.

Reconnaissance maps have been made of the entire Lewis and Clarke, Bitter Root, and Priest River reserves, comprising an area of over 12,000 square miles.

The total area mapped for publication as regular atlas sheets, on scales of one or two miles to the inch, in and adjacent to forest reserves, is 48,963 square miles (not including 12,072 square miles of reconnaissance maps), in connection with which 12,679 miles of levels were run and 2,983 permanent bench marks 
were established. This area comprises sixty-seven whole and five partial atlas sheets.

In the act of Congress creating the Geological Survey the director is charged, among other things, with the classification of the public lands. The work done under the forest reserve legislation was therefore in strict accord with one of the original purposes of the Survey.

Cruisings by private parties for private purposes have been made in this country for many years, but the work here briefly described is the first attempt to estimate and report upon the forests on a large scale for the information of the public.

The field force employed in the examination of forests has varied in different years, and most of the men have been employed for a part of the year only. This work being the first attempt to accurately examine and appraise the forests of this country, it was necessary both to build up an organization and to originate plans and methods for field work and for presentation of the results in reports and maps.

The work consists in the classification of lands as arable, pasture, desert, wooded, and timbered, timber land being defined as that bearing timber of merchantable size and quality, while wooded land bears only trees of sizes and species suitable for firewood, posts, poles, etc. The timber land has been roughly cruised to learn the approximate stand of timber, with the stand per acre; the species of trees, with the proportion which each species bears to the total forest, and the average height, diameter, age, and condition of the trees. The lands on which the timber has been cut or culled have also been defined, and the amount and character of the undergrowth, with its various species, and the depth of humus and litter on the forest floor, have been examined. 
The subject of fires, both ancient and recent, with their effects upon the present forest, has been carefully studied, and the accounts of large fires in times past have been recorded. A study has been made of the streams as means of transporting lumber, and the lay of the country has been considered with a view to the building of roads and railroads for lumbering purposes. The question of existing and future markets for the forest products has also been studied. The effects of grazing, especially the grazing of sheep, upon the present forests, and their reproduction, have been carefully investigated. The purpose of these examinations has been to ascertain the economic value of the lands and the forests.

Reports on the areas examined have been prepared and published, the earlier ones in volumes of the annual reports of the Survey and the later ones as professional papers. These reports are illustrated by maps showing the classification of the lands and the stand of timber per acre upon the forested lands. For this purpose the atlas sheets of the Survey are used, if completed. The reports are also illustrated by diagrams showing the stand of timber per township and the proportional distribution of the species represented. The map and the diagram together tell a large part of the story of the reserve.

During the last eight years there has been examined a total of about $75,000,000$ acres, or II 7,000 square miles. This area includes nearly all the reserves in the country, besides great extents of land adjoining them, and other regions which have been withheld from settlement with the expectation of reserving them.

Among these regions one was examined jointly with the Bureau of Forestry of the Department of Agricul- 
ture and the Geological Survey of North Carolina. It is a region of about 8,000 square miles in the Southern Appalachian Mountains. A report on this region will soon appear, and it will be particularly interesting because it is the first study of its kind ever made of the southern forests, which are characterized by a great variety and mixture of species.

A branch of the Geological Survey which has been much concerned with the forests and their preservation is the hydrographic. It is now understood by everybody that the occurrence and control of waters above and below the earth's surface are largely dependent on woodland conditions. The protection of the forests and woodlands is one of the first matters to be considered in any water-supply problem, and the study of the quantity and quality of water available for irrigation, power, and domestic and municipal purposes touches the domain of the forester.

In 1888 the director of the Survey was authorized to investigate the extent to which the arid lands might be reclaimed. Surveys of reservoir sites and of the catchment basins of streams were begun, and it was seen that it would be necessary to withdraw and hold permanently many of the forested areas above the reservoirs at the sources of the rivers. At all times there has been close coöperation between the engineers engaged in studies of water supply and the men investigating the forest reserves.

Upon the passage of the Reclamation Act of June I7, I902, and the organization of the Reclamation Service as a part of the Geological Survey, the question of the extent and preservation of forest reserves assumed increased importance. The scientific investigations of water supply were supplemented by authority to build great works, and there followed the 
necessity of protecting these works by every available natural resource. These great works might be seriously injured if individuals were permitted to come in above them and secure vested rights inimical to the larger irrigation interests of the country; therefore the Reclamation Service has asked that large areas of public land embracing forests or woodlands be withdrawn and held permanently, so that there might be no interference with the larger development of the waters.

In mapping the forest reserves and in recommending their boundaries all the large matters of this character have been taken into consideration. Frequently an individual, looking at the matter from his standpoint, is inclined to criticise the drawing of boundaries and to assert that too much land has been included; but if he would study the problem from the community or public standpoint he would find that this land is of great importance in connection with the control of the water supply necessary to the development of a reclamation project.

By carefully and systematically permitting the younger growth to accumulate, and perhaps by seeding the steeper barren slopes, it will be possible to reduce the destructive effects of the so-called cloudbursts or local storms which wash the loose soil into the reservoirs or clog the hydraulic works. The beneficial effect of this protection is well understood and every reasonable effort is being made to bring about the best possible conditions in the catchment basins of the streams.

Abundance of wood is one of the prime necessities for successful mining. There are four chief factors in the mining enterprise-the value of the ore, the cost of production, the cost of transportation, and the cost 
of reduction; and the sum of the last three must be less than the first, or the mine will be closed. Mining, properly understood, is a business in which the profits or losses are the result of the balance of these conditions, not an excavation of treasure whose enormous value renders other considerations insignificant. Now, in the three costs above enumerated, the principal elements are water and wood.

The cost of production includes labor, power (for hoisting, drilling, etc.), the mine plant (including all the necessary buildings), timbering, and supplies. Where wood is scarce or absent the price of building is enormous; rents and fuel are high, and the price of labor must be correspondingly increased. Probably the highest wages paid to miners in the United States are paid in the desert; for example, in the camp of Tonopah, in Nevada, where everyone underground receives four dollars per day. In this camp also the cost of power for hoisting is very high; the people are forced to use largely gasoline or petroleum, which must be brought a long distance with heavy transportation charges. The cost of the plant is proportional, a moderate-sized frame building costing $\$ 15,000$ to $\$ 30,000$; so that stone and iron have been largely used in construction, at a burdensome cost.

Timbering in most mines is an important factor. In the early history of the Georgetown (Colorado) mines, timbers were hauled by bull wagon from Iowa, until it was found that the native wood, though inferior, could yet be used. Vast quantities of wood are used for timbering in most large mining plants, and the price of the timber is one of the important factors in striking the balance of profit or loss. Thus the neighborhood of a forest and the character of the wood in that forest are of great importance. 
As to the cost of transportation, that, too, is invariably increased, other things being equal, by the scarcity of wood. If the bringing in of supplies and the taking out of ores is done by wagon, the high price of labor above referred to brings up the cost of haulage; if by rail, the heavy cost of ties for the road-bed and fuel for locomotives renders a high scale of charges unavoidable.

The cost of reduction is, for a given quality of ore, almost entirely dependent upon wood and water. In many a somewhat remote mining district, if wood can be obtained for running a mill, the ore is profitable; if not, the enterprise must be abandoned. At the desert camp of Silver Peak, in Nevada, vast quantities of fair-grade gold ore exist, suitable for stamp milling and amalgamation; enough water is available for such mills, but the great cost of fuel has hitherto stunned mining operations. When an occasional mill-run is made, in an old mill in this locality, the high neighboring mountains are scoured for scrubby pine, much of which is brought miles on the backs of burros, with the result that after a run the balance is as apt to be on the loss side as on the profit. Such deposits in a wooded country like California would form the foundation of a great mining industry.

The miner has a great and vital interest in the permanent preservation of the forests and in their intelligent utilization, second only to that of the irrigation farmer. He should be one of the strongest supporters of the Government in its attempt to preserve our woodlands and make them useful to all interests.

The saving of the wood of the living forests by the utilization of the lignites formed of the forests of Tertiary time is desirable if it can be done, and I have little doubt that it can and will be done; it is only a 
question of a relatively short period of time. The way to do it has been ascertained. It remains for enterprise and capital to develop and utilize the vast power resident in the lignitic coals of the West.

The Geological Survey has been conducting at the Louisiana Purchase Exposition a series of experiments in the combustion of coal and lignites.* This experimental work has been carried on under special authorization of Congress for "testing and analyzing the 'coals and lignites of the United States to determine the most economical method for their utilization." One of the most interesting results brought out in the course of this investigation has been the practical demonstration of the method for using the large supplies of lignite which exist between the Mississippi River and the Rocky Mountain states, and which, on account of its high percentage of moisture, make most unsatisfactory fuel under ordinary processes of combustion. It has been shown, however, that the very qualities which appear to unfit this lignite for use by direct combustion tend toward the improvement of the quality of the gas made from it in the gas producer. In the manufacture of what is known as producer gas all of the combustible material in the coal fed into the producer is utilized. The quality of the gas obtained is measured by its value in British thermal units (B. T. U's.) One B. T. U. is the amount of heat required to raise one pound of water one degree in temperature Fahrenheit. Ordinary bituminous coals make pro-

* This work has been in charge of a committee composed of the following members of the Geological Survey: Mr. F. W. Parker, Chairman, coal expert and statistician; Dr. J. A. Holmes, geologiat and chief of Department of Mines and Metallurgy, St. Louis Exposition; Mr. M. R. Campbell, geolo. gist in charge of aurveys in coal areas. 
ducer gas in which the British thermal units measure from I25 to I54 per cubic foot. It has been shown that the gas produced from the lignites of Colorado, North Dakota, and Texas ranges from 160 to 190 B. T. U.'s per cubic foot, and I have been informed that during a portion of the runs on one of the lignites from North Dakota as high as 2I6 B. T. U.'s were made in the gas. An average run of Texas lignite produced gas of a little less than I70 B. T. U.'s.

In the operation of the coal-testing plant, the amount of electric horse power produced by the consumption of the coal by two different methods was ascertained. One of these was burned under boilers connected with the steam engine, which in turn was connected with a dynamo that transformed this power into electrical units. In the other case a quantity of the same coal was burned in a gas producer, the gas thus produced being used in a gas engine, and the power thus generated being in like manner transformed into electrical units. By this means the amount of electrical power generated from the same coal or lignite under the two systems was easily compared, and it was found that in the case of the bituminous coal the economy of the gas engine over the steam engine ranged from 30 to considerably more than 50 per cent. Owing to the fact that the furnaces were not at the time suited to the use of lignite which disintegrates on exposure, attempts to use it under the boilers were unsatisfactory, whereas the quality of the gas produced from the same grade of lignites was from 20 to 25 per cent higher than that obtained from bituminous coal. This is partly offset by the fact that a larger amount of lignite is required to produce the same amount of gas, and it is also true at the present time that the installation of a gas producer and gas engine plant is more expensive than 
that of a steam engine plant, and that the expense of operating the former is slightly higher; but to demonstrate that these lignites can be used at all in competition with the bituminous coals is of inestimable value in the industrial development of the Great Plains region. The utilization of the great lignite beds of this aiea should remove, or at least greatly reduce, the necessity of its drawing upon the forests of the region for fuel purposes.

Tests made on the different grades of bituminous coals show not only a large gain in efficiency of the fuel in a gas producer plant over the steam plant, but especially they have demonstrated that with very dirty coals and those high in sulphur, results may be obtained that compare more or less favorably with the results obtained in the best type of steam plants using the expensive grades of soft coal.

It seems possible that future work may go even a step farther and show that "slack" coal, with even a large proportion of impurities, may be converted into producer gas and used in a gas engine, thereby replacing much of the high grade fuels now in use. Indeed, the present indications are that the economy obtained in the gas producer plant is such that it is destined to be the coming mode of producing power in the future, and through this great saving the low grade coals of the country and especially those of the western half of the United States will be more and more extensively used.

Of the cost of utilizing the lignites and bituminous coals in the manner outlined, and the distribution of the power obtained, permit me to say a few words in order that the practical business side of the matter may be laid before you. It is estimated that a gas producer plant with gas engines, foundations, and 
housings complete, capable of furnishing I 5,000 horse power, would cost nearly $\$ 800,000$. Such a plant would not be provided with apparatus for the recovery of the bi-products from coal. With the recovery apparatus such a plant would cost, approximately, $\$$ I75,000 additional. A steam-boiler plant with cross compound condensing engines, capable of producing the same amount of horse power, is estimated roughly to cost $\$ 70,000$ less than the gas producer plant without the recovery apparatus, and $\$ 245,000$ less than the gas producer plant with recovery appratus. The labor involved in the operation of a steam plant and a nonrecovery gas producer plant would probably be slightly in favor of the former.

Unfortunately, we have only incomplete comparative figures for the use of lignite in a plant of this kind, and the investigations at St. Louis have been almost of a pioneer nature on this line. But it is evident that either in the case of soft coal or lignite when used in the gas producer plant the saving in fuel would in a short time be more than sufficient to make up for any reasonable difference in the initial cost of that as compared with the initial cost of a steam plant of equal capacity.

In the present state of development of apparatus for the generation and transmission of electric power, the limit of line voltage is placed at, approximately, 60,000 volts, and at this voltage it is possible to transmit effectively electrical power at a distance of 250 miles. This means that a power plant established in the vicinity of coal mines can supply power to a territory having this distance of 250 miles for a radius, or, approximately, 200,000 square miles-more than four times the size of New York, and nearly twice the size of all the New England states and New York included. 
Such a plant established, for instance, near the lignite mines of Milam or Robertson counties, in Texas, could supply light and power to the entire state, with the exception of the far northwestern and western corners.

This brief sketch of the activities of the Geological Survey in matters directly and indirectly affecting the forests and woodlands of our country is given for the purpose of placing on record with this Congress what the Survey has been and is doing in this direction. The Survey is an investigating, constructive bureau of the Government, and desires to aid in every possible way in advancing the great work of preserving and utilizing the woodlands of the country.

From the point of view of effective administration, I believe that the examination, development, and administration of the forest reserves should be placed in charge of the Bureau of Forestry of the Department of Agriculture, and that the topographic mapping of the reserves and the adjoining forest areas should remain in charge of the director of the Geological Survey, and be carried on in coopperation with the Bureau of Forestry. 


\title{
WORK OF THE GENERAL LAND OFFICE IN THE ADMINISTRATION OF THE RESERVES
}

\author{
BY \\ W. A. RICHARDS
}

Commissioner of the General Land Office

PUBLIC forest reserves under the control of the Government of the United States had their inception in section twenty-four of the Act of Congress, approved March 3, I89I; which provides:

That the President of the United States may from time to time set apart and reserve, in any State or Territory having public land bearing forests, in any part of the public lands wholly or in part covered with timber or undergrowth, whether of commercial value or not, as public reservations, and the President shall, by public proclamation, declare the establishment of such reservations and the limits thereof.

No provision for the administration of the reserves so created appears to have been a matter of legislation until June 4, I897, when Congress prescribed the conditions under which such reserves should be established, to-wit: to improve and protect the forest to secure favorable conditions of water flows, and to furnish a continuous supply of timber for the use and necessities of citizens of the United States; and the Secretary of the Interior was authorized to make provision for the protection against destruction by fire and depredations upon the public forests and forest reservations and to make such rules and regulations and establish such service as would insure the objects 
of such reservations; that is, to regulate their occupancy and use and to preserve the forests thereon from destruction. The act also provides for the sale of so much of the dead, matured or large growth of trees found upon such reservations as may be compatible with the utilization of the forests thereon, and for the free use of such timber and stone on such reservations by bona fide settlers, miners, residents and prospectors for minerals, for firewood, fencing, building, mining, prospecting and other domestic purposes, as may be needed by such persons, but with a proviso that such timber should be used within the State or Territory where such reservations are located. Bona fide settlers, residents and prospectors are protected by said act in any rights they may have to any lands within such reservations, and provision was made for the relinquishment of any such claims or lands in complete ownership within such boundaries for any vacant public land opened to settlement, not exceeding the area of the tract exchanged. Inasmuch as the care of these reserves was so closely connected with the public land service, the Secretary of the Interior placed the immediate control thereof under the Commissioner of the General Land Office.

At the date of the passage of this act there were in existence nineteen forest reservations which had been created under the provisions of the Act of I89I, one of which was in Alaska, having an aggregate area of approximately $19,000,000$ acres. In addition to these eleven other reservations had been created, which were suspended by Congress from the effects of the President's proclamations until March I, I898, when said lands should become subject to the operation of said proclamations. These reserves had approximately an area of $20,000,000$ acres, or a total in both classes of about $39,000,000$ acres. 
There are now in existence a total of sixty-one forest reservations with an aggregate area approximately of 63,263,929 acres, located in fourteen States and Territories, as follows: Two in Alaska, eight in Arizona, ten in California; six in Colorado, one in Idaho, one in Idaho and Washington; one in Idaho and Montana, five in Montana, two in Nebraska, three in New Mexico, one in Oklahoma, four in Oregon, two in South Dakota, one in South Dakota and Wyoming, eight in Utah, three in Washington, two in Wyoming, and one in Wyoming and Montana.

To provide for the care and maintenance of the forests on this vast area, and to provide such rules and regulations and the enforcement thereof as would best subserve that purpose, and at the same time to overcome to some extent at least, the prejudice existing among the settlers and others to the withdrawal of such areas from the public domain, was the work that devolved upon the General Land Office. In furtherance of this object rules and regulations governing forest reserves were issued by the General Land Office June 30, I897, and approved by the Secretary of the Interior, in which it was clearly shown that while such reservations were created for the purpose of protecting the timber thereon, and conserving the water supply, the right of the public to secure timber therefrom, to graze live stock thereon, or to make any legitimate use of the reservations would not be prohibited, but only regulated in such a manner as would provide not only for present but for the future.

It then became necessary to provide for the enforcement of these rules and regulations, but owing to the limited appropriation at the disposal of the Department, very little progress was made during the first year in that respect. During the summer of 1897 six 
special forest agents were appointed for the patrolling of the reserves, and they were assigned to duty in California, Oregon, Washington, Arizona and New Mexico, it being the opinion of the Department that the reservations in those localities demanded more immediate attention than in other portions of the country. It is very apparent that such a limited force was not sufficient to obtain a great measure of success in the administration of the forest reserves, but on July $\mathrm{r}, \mathbf{1} 898$, a larger appropriation became available, and an attempt was made to organize the service on a somewhat permanent basis. The reservations then existing were grouped into eleven districts under as many superintendents, each of these having under his supervision and direction several forest supervisors, in immediate charge of the respective reservations assigned them, each of whom had under his personal direction a number of forest rangers, whose duty it was to patrol the reserves, to prevent forest fires and trespasses from all sources, to see to the proper cutting and removal of the timber designated by the supervisors where sales of timber had been made.

From the experience gained in the administration of the reserves various changes in the force of employees have been made until the present division of responsibility has been established, which has proven to be the best for a careful administration of reserve interests coupled with prompt action in any emergency that may arise. Some of the superintendents were dispensed with and their duties assigned to inspectors. The reserve force in the field is now composed of three inspectors, five superintendents, fifty-two supervisors, seventeen first-class rangers, one hundred and twentyfour second-class rangers and three hundred and 
twenty third-class rangers. By executive order dated December I7, I904, all of this force was placed under the Civil Service.

Each reserve is placed in charge of a forest supervisor, and if necessary, an assistant supervisor, and a number of rangers. This group of men is held responsible for the proper care of the particular reserve. The large reservations are divided into divisions, and to each division is assigned a forest guard. Each of these divisions is divided into as many patrol districts as are necessary, and to each patrol district is assigned a forest ranger. The dividing lines of the divisions and districts are generally mountains, canyons, rivers, or creeks.

The size of the district depends upon the topography of the country, the difficulty of travel, the amount of business likely to be encountered, and the ability of the officer in charge. The forest guard is held responsible for the satisfactory performance of the work and the condition of his division. He carries out the orders of his supervisor, assigns each ranger to his beat and headquarters and superintends and directs his work. He is required to keep watch over the work of each ranger in this division, and attend to any special work that may arise, such as timber sales, requests for free use of timber, and any matters demanding special investigations. $\mathrm{He}$ is required to visit his rangers as often as possible, to see that the affairs in his respective districts are being conducted in accordance with the regulations.

The assistant supervisor acts as field assistant to the supervisor in charge of the reserve. During patrol season he is required to look after the field force, notify them of all untusual affairs affecting the reserve, the transit of stock, new lumbering enterprises, prob- 
able influx of tourists or others, and to assist them in perfecting the system of signalling, of communication and of obtaining mail and supplies. To make his services effective the assistant supervisor should be thoroughly familiar with the woods. He must know every trail and every mountain pass.

The forest supervisor, who has permanent headquarters in a town near the reserve, having good mail and telegraph facilities, looks after all the office work and correspondence, and is also required to make occasional trips of inspection through the reserve. All instructions are issued by the General Land Office to the forest supervisor, who is responsible for the execution thereof through his subordinate force.

The forest inspectors are constantly inspecting the reserves, the field force and the general conditions thereof. The inspectors should be, and are men especially qualified in forestry matters. They are men capable of assisting the officers in the field, instructing them in all matters pertaining to forestry in general, and the needs of the reserve in particular.

All the field men located permanently on a reserve are required to furnish the necessary saddle and pack horses to be used in connection with their work, also camp outfits, which are necessary when the condition of the service requires long patrols.

The object of the service has been primarily the protection of the forest reserve, and, secondly, the interests of the settlers and residents within the vicinity of the reserve. The idea of withdrawing such a large amount of land from the public domain, the fear of losing the opportunity to use timber and to graze their stock on the lands so withdrawn, caused a great deal of antagonism to the forest reserve plan. This, however, was soon in a measure dispelled when it was 
ascertained that under the regulations of the Department all these privileges were still to be used, the only conditions being that such privileges should be exercised in a systematic manner, under the direction of the forest officers and for the future betterment of the conditions then existing.

The use of the forest reserves granted to the public is considered a privilege, not a right. It may be refused in any case, but as a rule settlers, farmers, prospectors and others who so desire may secure, free of charge, all kinds of timber for domestic uses, such as fire-wood, poles and logs, and if really needed, matured green timber. Applicants are not allowed to cut timber indiscriminately or wastefully, but can cut only such as the proper officer deems suitable for the purpose without injury to the reserve, and they are also required to utilize all the timber that can be used for any domestic purpose and to pile the brush resulting from the cutting in such a manner that it may be burned without injury to the surrounding forest. If firewood is desired, applicants are required to utilize any tops and limbs which may have been left from former cuttings; if building logs are desired, they must if possible utilize fire killed timber, or that which has become infected by insects or other destructive agents. If an applicant requires green timber, he is assigned to a locality where it has matured and is allowed to cut only the trees above a certain size which must be selected and marked by a forest reserve officer. A sufficient number of seed trees are always retained for the purpose of insuring a new growth. Corporations or persons desiring to obtain timber from forest reserves for commercial use are required to purchase the same, and in every case they are required to utilize all the timber, either for lumber, firewood, or other purpose 
and to pile the brush so that it can be burned without injury to the living timber.

Grazing upon the reserves is also conducted under the superintendence of the General Land Office, under the direction of the Secretary of the Interior. Whenever it appears that grazing will not damage a forest reserve or prevent reforestation, it is allowed to such an extent as a careful investigation warrants, so as to prevent any injury by overgrazing. In practically all the reserves cattle grazing is allowed, but sheep grazing is prohibited in some localities where it is likely to injure the forest cover or the young growth. Each reserve is divided into grazing districts, and persons holding stock grazing permits are assigned to a certain district to which they must confine their stock. This arrangement secures an even distribution of stock on all parts of the reserve and puts an end to the strife that formerly existed as to the right of settlers and others to graze their stock on certain lands to the exclusion of others. Whenever it has been determined that stock may be grazed in any reserve, parties desiring the privilege are required to file applications for that privilege, which if approved by the forest officer, are transmitted to the General Land Office for its action. Preference is given in allowing such permits; first, to stock of the reserve residents; second, stock of persons owning farms or ranches in the reserve, but not residing thereon; third, stock belonging in the vicinity of the reserve known as neighboring stock, and, fourth, stock coming from a considerable distance from the reserve, and all persons holding permits pledge themselves to assist in protecting the reserve and in preventing and fighting fires. The number of cattle, horses, or sheep that may be allowed in any reserve is fixed by the Secretary of the Interior for 
the following year at the end of each grazing season, and is determined by the report of the supervisor in connection with the effects of the former year's grazing.

In addition to the privilege of securing timber from, and grazing upon forest reserves which may be called general privileges, the General Land Office is called upon to pass upon numerous applications for special privileges, such as rights of way for irrigating ditches, railways, roads, the establishment of hotels, the erection of saw mills and the like within forest reserve boundaries. In all such applications the primary question to be determined is whether the exercise of such privilege will injure in any manner the forest or forest cover, or interfere with the proper administration of the reserve. If this question is answered in the negative, then it is to be determined whether the privilege sought will be for the welfare of the public or beneficial to the exercise of some right which the applicant may have already acquired, either before or after the creation of the reserve, and if so, the privilege is usually granted. The investigation necessary to secure this information is obtained by the supervisors under the direction of the General Land Office, and upon their reports action is based.

During the winter season when patrol duty is not necessary, a large number of the rangers are furloughed, leaving the supervisors and a few of the high grade rangers to care for the reserves, and to form a nucleus for the increase of the service during the following summer. These are employed in constructing trails so that the various portions of the reserve may be more easily reached, and fire breaks to aid in the control of forest fires. Twenty-one hundred and eighty-eight miles of trails and roads have been con- 


\section{PROCEEDINGS OF THE}

structed since the forest reserves came under the control of this office, while there were I I,924 miles of roads and trails there at that time, many of which are of sufficient width to form a fire break.

All these matters are under the supervision of the General Land Office, subject to the approval of the Secretary of the Interior. This system is somewhat experimental in its nature and is subject to improvement as the necessity arises. The appropriations have not been sufficient to carry on an effective administration, but the results so far achieved give promise that it is only a question of time when the service can be made self-supporting, to say nothing of the incalculable benefit that will result to those who live near the whose streams are fed by the waters therefrom. 


\section{A FEDERAL FOREST SERVICE}

\section{BY \\ GIFFORD PINCHOT}

Forester, U. S. Department of Agriculture

NoTE.-Almost immediately upon the adjournment of the Forest Congress a bill to transfer the care of the forest reserves to the Secretary of Agriculture became law. A national forest service therefore came into actual existence in the Bureau of Forestry of that Department, the name of which Bureau, on the first of July, I905, will be changed to the Forest Service. This paper has therefore been modified in accordance with the facts. It is now a statement of the objects and organization of the Forest Service.

THE National Forest Service has three principal objects. First, it is responsible for the general progress of forestry in the United States among the people at large, so far as the national government is concerned. This work rests upon the fact that in a government such as ours no movement can be permanently successful unless it is based on a general public recognition of its importance and utility. Since, therefore, it is essential to the well-being of the nation that its forests should not be destroyed, the first duty of the Forest Service is to place that fact clearly before the people.

Second, the Forest Service, being almost, if not quite, the only organization at present capable of so doing, is charged with giving private owners the knowledge of how to perpetuate their forests by wise use. The area of private forest lands in the United States does now, and probably must always, greatly 
exceed that of the government forests. Consequently, the supply of timber for the future depends more upon the treatment given to private forests than upon the national forest reserves. For this reason it is of the utmost importance to give practical advice and assistance to private owners so that they may be able to introduce conservative lumbering upon their own lands.

Third, the Forest Service is charged with the protection and administration of the national forests. These forests at present cover an area of rather more than $63,000,000$ acres, and are slowly increasing. They lie almost entirely upon high land at the headwaters of streams in the Western States and Territories, and are of vast importance to the irrigation and grazing interests, as well as to the users of wood. They are the key to the prosperity of the West.

The administration of the forest reserves is based upon the general principle repeatedly stated by President Roosevelt as the policy of his administration, that the reserves are for use. They must be useful first of all to the people of the neighborhood in which they lie. Nothing stands in the way of such use so effectively as the delays which are sometimes caused by official red-tape, and especially by referring local questions for decision at Washington. Every question which can be left to the local forest officers will hereafter be decided on the ground, and the office at Washington, as rapidly and completely as the new organization will permit, will be relieved from the consideration of a multitude of details which have hampered it hitherto.

Not only are the forest reserves in general for use, but every individual resource is likewise to be used, under the single restriction that it shall be so used as to 
become permanent. Timber, water, grass, minerals, are all to be open to the conservative and continued use of the people. They must be used, but they must not be destroyed.

This policy of use cannot be carried out with success unless the personnel of the Forest Service is of a high standard. It is of the first importance that every forest officer should be honest, intelligent, well informed in forest matters, physically active, and full of the right kind of interest in his work. Such interest is impossible unless the work offers a man a permanent career. That is why promotions to the higher positions in the Forest Service will invariably be made from the lower positions, when suitable men are available.

It is along these principal lines that the Forest Service will endeavor to make itself valuable to the nation. By deciding local questions promptly on local grounds, by opening all the resources of the reserves to reasonable use, and by the gradual creation of an effective staff of honest and interested public servants the Forest Service itself should become one of the really useful public agencies of the United States.

Vastly important as the national forests are, we must recognize that the bulk of our forests are now, and must always remain, in the hands of private owners; that it is only as the private owner, large or small, becomes interested in forestry and carries out its practical principles, that we shall succeed in introducing forestry into the United States. It should be remembered by every forester, and every man initerested in forestry, that the woodlands in farms are about three times as great in extent as all the national forest reserves, and that the reserves are almost insignificant when compared with the vast area of timberland which is owned 
by lumbermen in larger or smaller holdings, by railroads, or by men of various occupations who control the forests upon which the prosperity of this whole country depends. The forests of the private owners will have to be set in order if the overwhelming calamity of a timber famine is to be kept from this nation.

The extension of the present forest area, by restocking cut-over lands and by making plantations where there are no forests, is one of the chief duties of the present moment. This will be accomplished by helping the States to formulate their own policies, by active coöperation in studying the local situation in each, and by recommending the best procedure under the conditions that are found to exist. In particular, the farmers in every section of the counrty must be aided, either to develop their woodlots or to plant trees upon the prairies.

The forests now under government control should remain under government control so far as they are needed for public uses. We must have forest reserves, and we shall have to extend their area later on, not merely by presidential proclamation, but by purchase, both East and West. Forest lands are continually passing out of the government's ownership-lands whose preservation is absolutely essential to the wellbeing of the country where they lie. It will eventually cost the government of the United States hundreds of millions of dollars to get back again the areas which it once held, which are now in private ownership, and which are absolutely essential to the welfare of all of us.

I hope to see the Bureau of Forestry act as a helper and assistant, not only to the commercial interests, which is its first duty, but to all the interests of every kind that are in any way connected with the forest. 


\section{AMERICAN FOREST CONGRESS}

And this not by interference or dictation. I should like to have every man and every woman in this convention go home with the idea that the Bureau of Forestry is the servant of every one of you, and asks nothing better, and can hope for nothing better, than to be called upon to give you help to the utmost limit of its power. 


\title{
PROGRESS IN FOREST RESERVATION IN PENNSYLVANIA
}

\author{
BY \\ DR. J. T. ROTHROCK
}

Secretary, Pennsylvania Reservation Commission

T HE first requirement of a State is citizens. Pennsylvania, acting upon this fundamental principle early, adopted the expedient of selling land at the nominal price of 26 2-3 cents per acre. The State has long since outgrown the necessity of offering such inducements; but the law which authorized the same remains to this day unrepealed. In 1893 the Commonwealth still owned a few of its many acres, but these could not be located by any State officer and were only discovered when the surveyors, surveying unseated lands, found here and there a tract for which no claimant appeared.

Actual purchase of land by the States for the purpose of creating forest reservations commenced in 1896. So apparent had the necessity of such action become that, though the average price paid per acre for the land without timber was greater than the Commonwealth received for the land with all of its wealth of timber upon it, no criticism was evoked.

To-day Pennsylvania is in actual, or prospective, possession of about 700,000 acres, which has been purchased for the specific purpose of creating forest reservations, and thus to restore a normal proportionate area of wooded to cleared land. A Department of Forestry exists which ranks in recognized importance with that of Public Instruction, Agriculture, or Internal Affairs. 
This department has charge of land purchases under advice of the States Forest Reservation Commission, and of care of the land when purchased. It has since the commencement of the movement in Pennsylvania been our policy to move forward no more rapidly than public sentiment demanded, though an earnest effort was always made to create such sentiment, when it was lacking, but needed. It may be safely said that up to this time no legislature has ever denied what the forest officials of the State suggested, nor have we ever had a governor who failed most cordially and fully to support the forest movement since it took its present direction.

We recognize that land must be cared for it if is purchased; though we have not as yet placed caretakers over any considerable part of the State's recently acquired possessions. The principal reason for this has been that we did not desire to involve expenditure of public funds until the people themselves demanded it. This time seems to have arrived and the legislature will be asked this session to grant full, explicit authority for such action.

Thus far almost no land has been purchased in the regions which drain in the Ohio. The reason for this is that a large part of this area contains valuable mineral deposits, and could not be purchased without allowing the owners to retain their rights to the minerals. This difficulty did not exist in the districts which are drained by the Susquehanna, or the Delaware, because there the mineral belts were not of the kind we desired to secure for forest purposes at present. If, however, we had allowed retention of mineral rights by the present owners in the one district it would have been necessary to do so in the others. The Forestry Commission of Pennsylvania is now 
prepared to entertain propositions to purchase land in the regions which are tributary to the Ohio River.

We here merely allude to the ever recurring vital question of forest fires, to say that while we still anticipate our share of trouble, nevertheless public sentiment in Pennsylvania never was so crystalized against those who create them as now. This, of course, means fewer fires and a prompter suppression of them than ever before.

In the way of restoration of timber a good start has been made. We have opened an experimental plantation of white pine, and this year also made a good start in cultivation of black walnut. One nursery contains probably 300,000 seedlings which will be ready to set out in the coming spring. Our intention is to give the hardy catalpa a full, fair trial, though from what we have already seen of it in Pennsylvania our hopes are not as yet very high in regard to the tree.

The railroad directors of the State are considering the propriety of entering upon the cultivation of our black locut for cross ties, and one of our leading railroad corporations has already growing and in good condition about 250,000 young locust trees.

For the near future our State Forestry Commission is contemplating planting considerable areas, old farms obtained along with more extensive purchases, in white pine. This tree formerly grew there, and is now growing in the land adjacent in most thriving and desirable condition, with tall, straight limbless trunks, which promises a harvest of the oldtime "cork pine."

Our chief difficulty in the way of scientific forestry work has been the want of trained wardens. If we had enough of these we could for the time being get 
on with ordinary unskilled labor, where labor was required. The time will speedily come when we can pay liberal salaries to properly educated foresters, to produce and to work out a comprehensive plan for our operations. It is not here yet. To tide over the difficulty we have opened a forest academy in the South Mountain Reservation, and we have now twenty young men receiving elementary forestry instruction there. It is hoped to greatly extend the curriculum in the near future. One feature of our method of instruction is that our pupils divide their time about equally between manual labor in forestry and their studies. Thus far the combination has given fairly satisfactory results, and for the pressent we are inclined to continue it.

Pennsylvania has, we believe judiciously, started to utilize her forest reservations as sanatoria for cure of cases of incipient tuberculosis. Of course, the patients are not allowed to run at random over the ground and locate anywhere, but a place is set apart for them. The State has provided cottages and cabins and we now have, in the South Mountain, a colony of about thirty such invalids who are taking the fresh air cure. The results obtained have, in many instances, been remarkable. The probabilities are that this work will be greatly enlarged during the next few years.

On the whole, the outlook for forestry in Pennsylvania is hopeful. Some of our laws may be improved, but we have no legal or constitutional restrictions upon us which interfere with development of conservative forestry ideas or plans. 

IMPROMPTU ADDRESSES 



\section{Address by Hon. John Lacey}

Member of Congress from Iowa

$F$ OR the last fourteen years I have been a member of a little forest congress, originally composed of fifteen members and increased lately to seventeen, namely the Committee on Public Lands. The questions that you are discussing and will discuss during this conference here we have been struggling with during all this time. 'The problem of growing trees must of necessity be solved, not only by the private owner, but also by the State and nation. Congress has recognized the necessity of setting apart large areas of forests for the purpose of preserving streams for irrigation and for the benefit, I think, as well, of the public health; because the forest is a source of public health. The fact has been recognized that the Government must take some steps and take these steps in time. The movement has been late, but it is not too late. This vast area of the public domain (larger than Iowa and Ohio combined) that has thus been set apart, and I believe, set apart for the American people and their children and their childrens' children forever, need no longer remain in the custody of that great department whose main business it is to dispose of the public land, to transfer it to the private individual for his home; and, therefore, for several years I personally have championed a measure which would remove from this great committee one of its most pleasing duties, but yet would transfer it to a department better fittedadmirably fitted for the future care and preservation of this great domain. And it is not news to you, and 
yet it is worthy of record here, that this measure has passed the House of Representatives and is now pending in the Senate of the United States; and your judgment and influence will go far, no doubt, to secure its passage through that wise and great though somewhat slow moving body. We have at the head of the Department of Agriculture the great head of forestry. I, perhaps, do not mean the gentlemen that you are all thinking of. It is not my dear young friend, Mr. Pinchot, but the old man, who comes from the prairie State of Iowa, a State whose chief forests consisted of hazelbrush in the days when the Secretary of Agriculture first settled in his magnificent domain. And I might say to you that so far as that State is concerned, it is quite too rich to use much of it for forestry. They can hardly afford it. With the land at one hundred dollars an acre to plant out in trees, the crop of which will be harvested seventy-five years from now, is almost too expensive even for a nation to undertake, so Iowa will never be a forest producing State. The head of this department will be succeeded some day-I hope a long time in the future-by some man of equally comprehensive grasp and an equally prophetic view of the future. That department has come to stay, and it is a department that may look far into the future and do that for the nation and for the people which the private individual, or even the State, is not adequate to accomplish. And, therefore, it is well that when these reservations have finally been delimited and their outlines fixed, that they should be transferred, not to a department whose business it is to pass the title away to individuals, but to a department that will hold on to this land, that will turn it over to succeeding administrations, and that will preserve the sources of the water supply of the country in the West, whose future 
is entirely dependent upon the successful operation of irrigation. And that is why, my friends, this transfer to a different department is a matter now of necessity when this vast domain of sixty-two or sixty-three millions of acres shall have been selected for that purpose.

There is another reason for the transfer. I referred a moment ago to my young friend, Mr. Pinchot, who is the chief forester of the Department of Agriculture. It has been an anomaly in our legislation that the department of the Government having charge of the forests had none of the skilled foresters of the United States in its employ, and that the department that did not own a tree anywhere was surrounded by the best corps of foresters in the world. The mountain could not come to Mahomet, and so Mahomet is going to the mountain. The department is to be transferred-the service transferred-to that department that is so notably fitted and so organized as to take the permanent care of this magnificent, this wonderful domain. I was born in the woods of Virginia. I moved (thank God), to the prairies, and one of the most unpleasant things of my subsequent life was to return to the woods of Virginia, now West Virginia, to find that the old streams-the old "swimmin' holes"-as Whitcomb Riley calls them, the holes we used to swim in and where we caught so many fish, are now simply gravelly roads. They are highways as dry, as arid, as one of the deserts of Arizona or New Mexico-nothing but beds of gravel. And why is it? Because the trees have been cut down and the springs that were the children of the forest, have dried up, and instead of a slow running brook digging out holes here and there, clear as crystal and full of water, we have simply an increased torrent after each storm, carrying the pebbles 
and the sand from the hills, washing them down and destroying the old brooks.

Now this is one of the unpleasant features of the denuded timber lands of the Eastern States. I see here before me representatives from every State and Territory in the Union, because this question has become a national one and has gone into the homes of the people. It is not too late to save some of the great Appalachian forests of North and South Carolina. It is not too late to save the valleys of many the Eastern States from that destruction which followed the denudation of the forests of France when the hilltops were carried down into the valleys and the rich alluvial plains absolutely buried with sand and gravel. It is not yet too late, although many a fertile field has been destroyed.

I can look at this from an impartial standpoint, without prejudice, living in a country that has no forests, that never had them, that never will have any great forests; where we have a climate in which there is always rain enough to grow a crop and drought enough to dry it for harvest; where all we need in the world is to be let alone.

I did not come here to talk to you this morning. I sat down in the audience simply because I wanted to touch elbows with those who are carrying this crusade in favor of the forests into every part of the United States; but I am glad to have this opportunity to look these earnest people in the face and to bid them Godspeed and good cheer. There is no nation in the world that has been so extravagant, that has been such a spendthrift of its natural resources as the American nation. We tap a gas field, set it on fire and advertise for everybody to come and see it burn up-a gas field that it took countless millions of ages to store under the 
cap of a rock that covers it-and yet in a few years it is destroyed, and the factories that were built over it with the understanding that an everlasting source of supply existed underneath, find themselves once more shipping coal from hundreds of miles away in order to supply their furnaces. The same is true with oil ; the same with the beasts of the forests and the birds of the air. People destroy them with a wantonness that almost looks like malignity; and all these natural resources of the great United States of America are involved, either directly or indirectly in the questions that you are going to discuss. While preserving the forests you will preserve the animals that roam therein; while preserving the forests will give shelter to the birds of the air that make their nests therein. It is too late to save the wild pigeon, perhaps. The countless millions that used to break down the woods by their weight have disappeared, and the advent of a dozen wild pigeons in the State of New York is taken up by the Associated Press and published far and wide as a wonderful thing: "A dozen wild pigoens were seen in western New York day before yesterday." And yet, within the lifetime of my young friend Pinchot, and I refer to him because I look to him for the future of the forests, in the lifetime of even the youngest members present here, this magnificent bird has practically disappeared from the face of the earth. I know my friend, the Secretary of Agriculture, will not fully agree with me upon the importance of the preservation of the buffalo; but I expect some day to get him to entirely agree with me.

This is a day of progress. It is not very long ago that men rejoiced at the destruction of the buffalo, because it opened the way for the white man in the West. We took up the subject in Congress some years 
ago, while a few remains of this magnificent animal were still upon the earth. It was my good luck to secure a small appropriation from our economical chairman of the Committee on Appropriations-not a very sentimental man, but one of the most practical men on earth-Uncle Joe Cannon-a small appropriation of $\$ \mathrm{I} 5,000$ to restore a herd of bison to the Yellowstone Park. Four hundred of these creatures were enclosed in the area that was reserved when this land was set apart as a pleasure ground for the nation. Those four hundred have gradually been killed for their heads and for their pelts, and the calves have been destroyed by the mountain lions and by the severity of the winters, until finally only twenty-three were the sorry remains of that splendid herd that was set apart for the nation in the Yellowstone; and the small appropriation of $\$ 15,000$ was made. Eighteen animals were purchased, part of them from the Flathead herd. The Flathead Indians, with more prudence than their white brethren had shown, saved thirty-five calves a good many years ago, out of the dying herd, and made them their private property. And that little herd of thirty-five increased until there were nearly three hundred of them. And this herd now in the Yellowstone was selected mainly from the Flathead herd because they were reared in an altitude something like that in which the new herd was to live. To this herd were added animals from Texas-from the Goodnight herd-and from Corbin's New Hampshire herd-so as to mingle the blood normally in this new herd as the blood of the nations has been mingled in the United States of America. This is the way to produce a race, to mix them and get the best you can from everywhere. And so, starting upon the proposition of building once more a herd in the Yellowstone, that little herd from 
eighteen has grown to thirty-nine, and we have hopes of sixteen more in the spring.

Now I only speak about this, my friends, because it is a kindred question. It is one of the things that grows out of the agitation of forestry. A man or a woman who preserves a tree in a practical way will preserve the things that that tree shelters and produces and that are useful to man. Again, I wish to bid you Godspeed, and I hope you will carry with you to every part of the United States the enthusiasm which you will generate here-the enthusiasm which you bring here and which you will convey to one another-and that you will be a mighty band of missionaries all the way from Portland, Maine, to Portland, Oregon.

\section{Address by Hon. W. A. Reeder}

Member of Congress from Kansas

I REGARD it as a privilege to be permitted to speak to so intelligent an audience from all sections of this great country of ours, interested in so vital a work as the preservation of our forests. I had the good - fortune to be born in one of the best valleys of Pennsylvania, the Cumberland Valley, but I had the better fortune to be removed, very early in my history, to the Solomon Valley, in the semi-arid regions of western Kansas, and for considerably over a third of a century I have lived in that section, and it has probably changed my characteristics considerably from what they would have been had I remained in the land of my nativity; also my interest in certain matters, particularly the matters of irrigation and the preservation of our forests.

What a dense population we will be able to find 
homes for in the vast arid and semi-arid regions of the West when we put water upon those semi-arid and arid lands! Incidentally, I wish to remark that the district I represent has more tillable acres than all of Japan, and while we have 200,000 population or less, Japan is supporting $43,000,000$ of people. With irrigation we can accommodate as dense a population as is supported on any equal sized territory in any part of the world. Mine is one of the seven congressional districts of Kansas, and Kansas but a small portion of the territory that can and will be irrigated by means of the irrigation law. The subject I desire to present is this: You are interested in matters that are vitally important to irrigation. Important because of the conservation of water by the forests at the head of streams which supply water for irrigation. The timber should be preserved in order to conserve this water. You are also interested in another subject which has been spoken of by several, which if handled rightly, will add largely to the funds of the great irrigation movement. This is the sale of the timber on the public domain for something near its value. We are something of an impetous people in Kansas, and have seen times when we had to be somewhat practical. I am glad to add, however, that we are very prosperous at present. We Kansans who are interested in irrigation feel that the matter of changing our laws in regard to the sale of timber at something near its value, should be consummated, and that soon. We Kansans are urgent in the matter and would go direct to the source of the difficulty delaying such action. It should have been arranged at the last session of Congress, or even before that, in my opinion.

The great irrigation convention held at El Paso, Texas, in November, 1904, composed of men from 
all parts of the nation, adopted resolutions asking that our present land laws be repealed and a system of laws substituted providing for the sale of the stumpage of our timber, and now, this great convention of representative men and women express themselves so earnestly in the same manner, that I ask myself why is it so small a number of people, the speculators in our timber land, can control in these matters against the great mass of our influential citizens? I fear you are not practical enough. Your are not fighting at the right place. The Congress of the United States has control in these matters. The men who appeared before the Committee on Public Lands last year, and argued in favor of retaining the land laws as they are, are not holding meetings; are not passing resolutions; are showing no particular enthusiasm; but they are doing the business. I say this with the utmost respect and regard for the chairman of the Public Lands Committee, Congressman Lacey, who is on the platform. In my judgment, our timber law should have been changed long ere this. I wish every member of this organization would read the hearings before the Public Lands Committee of the House last year. I wish you could, in some way, induce this Public Lands Committee of the House, who are solely responsible, to permit the question of the repeal of these very harmful laws to come before the House for consideration. This is the only practical method of reaching this important question. I further wish to assure you that resolutions will not accomplish this result. A bill for the repeal of the Timber and Stone Act has passed the Senate, and the Committee on Public Lands of the House have already decided the House shall not be permitted to consider it for one year more at least. All your influence should be used with the members of this com- 
mittee, in order that the matter may be considered by the House. I am satisfied that Congress is willing to repeal this Timber and Stone Act and put in its place laws for the sale of the stumpage, if they are permitted the privilege of considering the question.

I thank you for this privilege, as I was anxious to put this matter before you, and urge you to commence an effort by seeing members of the Committee on Public Lands of the House, or indirectly using your influence with them. This committee has absolute control in this matter. If they can be induced to permit the matter to come before the House, you should then urge your member of Congress to work and vote in line with your wishes in the matter.

\section{Address by Rev. Edward Everett Hale}

Chaplain of the United States Senate

I SHOULD be glad to be called upon at any time, day or night, for twelve hours or twelve minutes, to speak upon this subject, anywhere or to anybody who had any interest in it. I represent here the State of Massachusetts, as well as the State of New Hampshire; I represent also the Appalachian Association, which is a large organization and has done a great deal of good. But I am not going to speak as a New England man; I am going to speak as an American.

I have slept under pine trees, which were high, tall, beautiful pine trees when North America was discovered. I went up through the same region two years ago with a friend and found my pine trees all gone and sumac and blackberry bushes in their places. It makes a man cry to see it. I have talked with lumbermen who knew where they could find pine trees that had 
King George's mark on them, because King George, in 1770 , valued his New England forests so much that he would not let anybody cut down pine trees without his permission, and he placed on the trees the broad arrow of the English Admiral. Fortunately, he was not able to cut down the trees afterwards. Now we are before Congress because we want Congress to preserve the forests for fifty square miles in that region. I desire that my boy's boy's boy's boy's girls, two centuries hence shall see such pine trees as I saw in I84I. And for like reasons, we want an Appalachian reservation made in the highlands of Tennessee and the Carolinas.

\section{Address by Mr. W. S. Harvey}

Vice-Preaident, Pennsylvania Forestry Association

I $\mathrm{T}$ is exceedingly gratifying to me, as an officer of the Pennsylvania Forestry Association, which association, you are all aware, has been one of the pioneers in the work for forestry, and probably has done more than any other association, and has a larger membership than any other association, except the American Forestry Association, of which I also have the honor to be a member of, and of the Board of Directors.

The highest tribute that has ever yet been paid to the forestry work of the United States is being paid to-day by this notable gathering of influential people, not only from every section of our own country, but from our kindred country, Canada. We have listened with great interest, and I sincerely trust it will be with great profit, to the words that my countryman, Dr. White, has just uttered, in telling us how intelligently Canada is administering her forests, and this Congress 
will fail of the responsibility that rests upon it to do practical work, if we do not, before we disband, take action of a nature that will enlist the influence of every one here and the organizations they represent. Railroads, timber owners, and lumber manufacturers, those interested in irrigation, those interested in mining, those interested in industries collateral to the forestry question, we should enlist their coöperation and service to have laws enacted in the United States that will at least put the United States on an equal footing with our neighbor, Canada. I sincerely trust that we will not adjourn without having some resolutions passed that will invite the coöperation of all the bodies here represented, to have the Timber and Stone Act repealed. The Timber and Stone Act, as we have learned in the Secretary's report, allows the United States Government to sell land in fee for $\$ 2.50$ an acre, while the reservations of the Chippewa Indians, which were sold at public auction in December of I903, realized for the timber alone, the land itself being reserved, $\$$ I 5.06 an acre, or more than $\$ 2,600,000$, as against $\$ 438,000$ that the Government would have received at $\$ 2.50$ an acre. Why should the United States Government sell what it owns for less than its real, its market value? There is no reason in the world why this should be done, and if I am not out of order, Mr. Chairman, I think it would be appropriate that I, or some one else, should make a motion that the recommendations that are in the Secretary's report shall be referred to the Committee on Resolutions; that the Secretary be requested to tabulate those recommendations so that he can present them to the Committee on Resolutions, so they can consider them and bring them before this Congress to be acted upon before we separate. 
The purpose of our coming together, with the important interests represented and identified with this Congress, is to produce practical results. Our distinguished President said, in the address which he read to us this morning, that the "period of talking is past and the period of doing has come." I think all of us can rejoice in the fact that there has never been a period in the history of the United States that was such a period of doing. We have to-day an administration that does things. American citizenship has been exalted in the eyes of the entire world through the methods of doing those things. Mr. Chairman, it is an administration where personnel counts for much, and we are greatly honored in the work that many of us have been so deeply interested in for many years, in having you at the head of this great economic work. At first we were ridiculed for being theorists and idealists, and we were told that there was nothing practical in our ends and aims. We are thankful today that that spirit has disappeared. We are also highly honored in having the President of the United States the honorary president of this Congress, who will also deliver one of the most important addresses, which address is to embrace in its scope, forestry in its relation to the United States. Probably all of you are aware that perhaps we to-day would be aborigines if it were not indirectly for forestry.

You all know the man who discovered America more than four hundred years ago. Columbus had great trouble with his crew, they mutinied and had decided that they would allow him no longer to pursue his course to find land that they never believed would be found, and they determined that they would compel him to return to their native land, and just at that juncture one of those men, looking overboard into the 
sea, saw the fresh limb of a tree floating in the ocean, and they then thought land must be near, and they determined they would pursue their course, and America was discovered as a result of that incident.

The president of this Association, our distinguished Secretary of Agriculture, who is the most modest man that was ever sent to Washington from Iowa, is a man who also "does things," and the greatest guaranty and the best earnest that we can have of the future of the forestry work, is that Secretary Wilson is at the head of it. The department of which Secretary Wilson is the head, we must not overlook the fact, is the one department of the Government that produces things. Every other department of this Government is a matter of expenditure; Army, Navy, Interior, Post Office, Commerce and Labor, and the Treasury Department. All of these departments are departments that require enormous expenditures. The Department of Agriculture is the department that has done more than any other department in the United States to increase the wealth of the United States. Friends in Wall Street say "Secretary Wilson is the greatest bull factor on the whole financial horizon."

$\mathrm{He}$ has recently made a statement that the value of the products of the soil in the United States the past year is four billion, nine hundred million dollarsfour hundred millions dollars greater than they were one year ago, and they say a shrinkage in securities in Wall Street, from one to two billions of dollars, does not amount to anything serious when the actual wealth of the country is increased four billion, nine hundred million dollars.

Secretary Wilson is going to hold himself responsible for the future of the work of this Association; also his associate, Mr. Pinchot. We all delight to give 
honor and credit to this gifted young man, and every one of us is sorry that we are not as young as Mr. Pinchot, to go with him into the great future of this work. It is going to have a great future, and I am glad to say as a representative of the Pennsylvania Association, that Pennsylvania is ready to go hand in hand and coöperate with you in every good measure of legislation, national or state, that may be desirable, and one of the important purposes here should be to find a base of unity and harmony of action on all national questions. If we can interest earnestly and sincerely the interests that are represented here to-day, and representing the many states that they do, I undertake to predict, and I say it without any qualification, that I believe there is no legislation that we will not be able to secure, because the people who represent the forestry movement to-day will not ask anything that will not be desirable or beneficient or wise and good for the interest and welfare of the country.

As a member of this Congress from the State of Pennsylvania, that is indirectly interested in the Appalachian Forest Reserve, I want to raise my voice here in advocacy of using our influence with the Congress of the United States to make it possible that we have a forest reservation in the Eastern States. We have learned in the figures that have been given us that the United States owns 63,000,000 of acres of reservations, every one of which is in the West. The Appalachian Reservation, the purchase of which has been endorsed and advised by commercial bodies throughout New England and the East, by various forest associations and by the National Board of Trade for several years, at their meetings in January, in Washington, embraces $3,840,000$ acres of land, covering an area two hundred miles long and twenty to forty 
miles wide-an average of about thirty miles. The importance of securing it by the National Government is of great vital interest to this Congress. This Congress is to consider economic questions from a practical point of view. The Southern States have more than $\$ 200,000,000$ invested now in cotton mills. These cotton mills are in a large measure dependent upon water power. The taking of the forest cover from the Appalachian Mountains will largely destroy the opportunity nature has given the South to grow and increase in wealth and prosperity, which it is doing and which in the future it will to a greater degree than any other section of our country. Some of you may not be aware of the fact that the head waters of all of the rivers that I shall name are in this Appalachian range: The Potomac, the James, the Shenandoah, the Roanoke, the Dan, the Catawba, the Yadkin, the Broad, the Santee and the Savannah on the east. On the west we have the Cumberland, the French Broad, the New, the Tennessee, the Kanawha, and the Ohio. The names of these rivers should impress us with the significance and the importance of providing a forest reservation in the Appalachian territory in the Middle East. Resolutions were passed by the American Cotton Manufacturers' Association in convention in the city of Washington on the I2th day of May, I904, as follows: "Whereas, we recognize a great source of danger to our water powers in the indiscriminate cutting of timber at the headwaters of our streams; and whereas, this opinion is confirmed by uniform experience in other countries, where drastic remedies have been successfully applied; and whereas, our future as a manufacturing nation is largely dependent upon cheap power secured from our rivers and streams; and whereas, owing to the great improvements being made 
in electrical transportation our water powers should be greater factors for furnishing power in the future than they have in the past; and whereas, the sources of the streams where the injury is done are often in other States than those in which power is used, hence this vital question becomes one which the National Government alone can properly deal with."

There is another important point, and that is the fact that the southern Appalachian Mountains embrace the last remnant of the hardwood forests of the eastern United States. Owing to there being no swamps or lakes in this entire region, almost the entire rainfall will be lost at once if the forest cover is removed. Upon the continuance of this forest cover depends almost entirely the water power, navigation and agriculture of the regions south of the Ohio and Potomac Rivers and east of the Mississippi. This proposed forest reserve extends through several State, and it is not practicable to depend upon State action. I, therefore, Mr. Chairman, in view of these important facts that should impress us with great earnestness and determination to take action at this time, recommend that this question be referred to the Committee on Resolutions, and I sincerely trust that the Committee on Resolutions will take definite action and bring before this Congress a resolution for their adoption.

\section{Address by Mr. Aubrey White}

Commissioner of Crowa Lands, Ontario, Canada

ASSURE you I am taken completely by surprise in
being asked to address you at the present moment.
I had naturally expected that at some time during this
Congress I might be asked to say something in connec- 
tion with forest reserves and our management of them in the Province of Ontario, but I was not prepared to speak at any length at the present moment. I cannot, however, refuse to say a few words in connection with the forest reserves of Ontario and their management. At the outset I wish to say that I am a great lover of the forest. In' my early days in Canada it was my good fortune, first, to trade with the Indians in the remote part of the province, afterwards, to be engaged in the lumber business, first in the subordinate position of cutting roads and gradually working up, until at the present time I am in charge, as the permanent official of all the timber and Crown Lands of the great Province of Ontario. In my peregrinations through the back country by canoe, particularly after coming over a long, tiresome portage, it was often a source of great delight to me on putting my canoe down off my head to see a little lake surrounded by the beautiful green forest, figurately, like a diamond set in emeralds. There can be nothing more gratifying to the eye of man than such a sight, particularly under such circumstances. And then, as the eloquent gentleman who has just addressed you a moment ago, said with respect to his experience in his own State of Virginia, I have gone back later to some of these little lakes and seen them spoiled, the timber having been burned up and the locality denuded of all its beauty and become an eyesore in the landscape. Therefore, as a lover of the beautiful, as one who is fond of nature, I am anxious to do everything in my power to educate the people upon the subject of forestry, and the conservation of our forests, as well from the standpoint of the beautiful as from a commercial standpoint.

We in Canada have an altogether different system in managing our forests from what you have in this 
country. I sometimes think it is better to adhere to an old system, improving it from time to time as experience may dictate, than it is to evolve a new system. The genesis of our system of forest management is to be found back in the days of the French regime in Canada. At that time, when the Crown was parting with the soil, it reserved to the King of France all the timber on the land that was suitable for naval purposes. The oak was the principal timber used for naval purposes, and it was the timber reserved. Permits had to be obtained to get into the forests and cut it. When the country came into the possession of the British, the same system was still pursued, but by this time pine had become the valuable naval timber, and it was reserved, and so it has been ever since. In all the titles we give to settlers and others, we reserve the pine timber until the patent has issued. So far as the Province of Ontario is concerned, our principal revenue is derived from the sale of pine timber. We have no State $\operatorname{tax}$ as you have in the different States of the Union. The people of Ontario are not taxed one five-cent piece for State purposes, if I may put it in that way. Our principal revenue comes from two sources, first, the per capita grant made by the Federal Government to the Province, and the other, the proceeds of the sale of our timber and lands. This last year, I904, our revenue from timber alone was some $\$ 2,800,000$. When we determine to dispose of any quantity of timber, we survey it in what we call "berths," that is, blocks of land having an area of from two to fifty miles, as the case may be. Then we advertise the sale very widely, notifying the people to come and bid for these blocks. Before the day of sale we have them carefully inspected, the timber upon them estimated, and we put a value upon each block, 
which is called the "upset price." Then we put them up for sale by the mile at a price which we call the "bonus value," that is, the amount of money paid for the privilege of obtaining a license to cut the timber, subject to a royalty when it is cut. The present royalty, exclusive of the bonus paid at the sale, runs from $\$ 1.00$ to $\$ 2.00$ a thousand. The bonus derived from a sale is sometimes enormous. At the last sale we held in 1903 , we received $\$ 30,500$ a mile for the right to cut timber on a certain berth, with a royalty of $\$ 2.00$ per thousand feet, board measure, to be paid as the timber was cut and removed. We have a very valuable asset in our pine timber and we are taking care of it, we are not giving it away. Now, you have had in this country, as we have, the problem of preventing the destruction of the forests by fire. When I entered the service of the Ontario Government, one of the first questions addressed to me by my chief was, "Can you not recommend something by which we can prevent the forests being destroyed by fire?" I said I thought I could, and I evolved the plan which has been copied in all the provinces and by the Federal Government, and is, I think, if I may say so without egotism, now followed to some extent, at any rate, in the United States. I said we should try to guard the forests during what may be called the dangerous period; that is, from the month of May to the beginning of October. We have some 20,000 miles in the Province of Ontario under timber license, and my suggestion was that the owners of these licenses should be asked to recommend or select men who were cool-headed and knew their limits, as such men could best protect them, that these men should be put on duty as fire rangers or fire police during the dangerous period, the Government bearing one-half of the expense and the timber licensees the 


\section{AMERICAN Forest CoNGRESS}

other. I suggested that the licensees should be asked to name the rangers because I wanted to get capable men and to divorce the service from any connection with politics. If the Government had appointed all the rangers $I$ fear we would have had the insinuation that some of them were appointed for political purposes. In order to get rid of that idea once and forever, we said we would allow the licensees, who were of all schools of political thought, to select the men, then we will appoint them and pay half their wages. That system has been approved and expanded and is in force at the present time. During the last year, in the Province of Ontario, we have not had a single forest fire, although thousands of people are moving about through the forests during the summer season. Large numbers of your own countrymen come up to our country during the summer, regarding it as a playground because we have the forest there in which they can come in contact with nature and enjoy themselves. Recently we have thought we ought to go a step further; that we ought to set apart large tracts of land as forest reserves, the timber of which should be cut subject to regulations as to the size of the timber and measurements and everything of that sort, and that the trees to be cut should be marked by rangers appointed by the Government, the timber to be disposed of in the open market from time to time as might be thought proper. We have set apart in the Province of Ontario some 7,000,000 acres of forest reserves, and we have on these 7,000,000 acres probably some 10,000,000,000 feet of white pine timber, and in this white pine we think we have one of the most valuable assets that any province or State could have, because there is no property that is more rapidly increasing in value than white pine stumpage. We are using our best efforts 
to take care of it, to protect it, and I think I may say that so far as the prevention of the destruction of the forest by fire is concerned, we have almost, if not completely, solved the problem.

I am delighted to have had the opportunity of saying a few words to this great Congress upon the management of our forest reserves. Necessarily I have been somewhat disjointed in my remarks, being called upon on the spur of the moment without any preparation to address the meeting. Before I sit down I want to congratulate you, Mr. Chairman, and I want to congratulate everybody present upon the amount of good that can be done by such a meeting as this. If everyone here is determined to do everything in their power to educate the people upon the subject of the protection of the forest and its conservation for national purposes, I think we shall have a better public opinion upon the matter.

\section{Address by Dr. B. E. Fernow}

Author of " Economics of Forestry"

I $\mathrm{T}$ was said this morning that the time for talking is past and time for action is present, and so I supposed that talking was no longer in order and had not even thought of what I might say to you should I be called upon. I might, however, be reminiscent of an occasion similar to the present one, when the first Forestry Congress was called, to Cincinnati, in I882, when the first attempt was made in the United States to arouse public attention to the necessity of the subject which now occupies this large assembly. Do not believe for a moment that those were all sentimentalists that came together at that early stage of development. 


\section{AMERICAN Forest Congress}

There were economists present with sentiment, to be sure, but not moved by sentimentality. Later a large amount of sentimentality was introduced into the subject, thanks to the ladies, and this, too, was a good thing at the time, because in that way interest was gradually spread among all classes of the public, even to the practical men of the woods. I feel greatly gratified that all the talk that we of the earlier ages performed, has made it possible to bring together such an assembly as the present one, with practical men, the lumbermen themselves, in the audience and on the platform. It has taken a large amount of talk to make that possible, but still more so, as was stated by the secretary of the Association this morning, the natural development of economic laws has brought around a good many who doubted the necessity and propriety of our earlier work.

As far as the Federal Government's interests are concerned, I dare say they are now well understood and cared for, and some of the States are initiating the Federal Government and have been awakened to their duty. They have begun to perform it, and as time goes on, will perform it better and better. As far as private interests are concerned, I want to accentuate the fact which Dr. Schenck tried to bring out this morning, namely, that the lumberman is a necessary agent in our civilization and that the lumberman, while he serves himself, serves civilization, althongh I dare say that not one of the lumbermen here has gone into business for the purpose of helping civilization along, but for the purpose of helping his own pocket. The private interests, then, leaving out the interest of the nation at large, lies in the profit that might be expected from a change in the use of forest properties. It would be difficult for anyone to prove that such a change at 
the present time, adopting forestry methods, would lead to on immediate increase of profits. Forestry is profitable only in the long run, in the future. To discuss its profitableness you must be able to predict what the needs of the future in the use of wood will be, and what the prices are likely to be.

Now I have, within the past few weeks, occupied myself with this most important question: Will wood prices rise, and will it pay at the present time to spend money in the care of forest properties, or to leave money in the forest properties, not taking all that can be taken at the present time with a view to an increased revenue in the future? This is somewhat of a technical subject, but I believe you will have to deal here with technical subjects in formulating a policy which appeals to the interest of private forest owners. Contrary to the statement of some statisticians of name and fame, wood prices have been, even in the United States, rising continuously for the last seventy years at the rate of about one and one-half per cent; and at the present time, if you take shorter periods of ten, fifteen or twenty years, you will find that this rate of increase has been very much greater. In the last forty years the industrial nations of the world, such as England, France and Germany, as well as the United States, have increased the wood consumption to a marvelous extent, not according to the number of their population, but an increase per capita consumption. This is a remarkable fact when we consider that stone, iron and steel have taken the place of wood in building materials to a large extent, and coal has replaced it as fuel. So -it is impressed upon us that our civilization is continuously dependent upon wood. Hence a supply for the future is one of the requisites of our modern civilization. The consideration of the rapid increase in the 


\section{AMERICAN Forest Congress}

consumption, which means, of course, a rapid decrease in the natural supply, and hence an increase in price, is the first basis upon which to discuss the question of private interests in forest properties. We can now prove that forestry will be profitable, for the history of the past gives us a clue to the history of the future.

But we may discuss this question and we may discuss the methods of forestry ad infinitum, yet we will never succeed in persuading the private owner until we have produced the conditions which make it possible to hold forest property uninjured for the long time which is necessary in order to reap the benefit. Of course, you will see at once that I am coming to the fire question. I have come down to this last issue as the one which must be solved first before the others can be approached. One incident will suffice to illustrate what I mean. A lumber company in New Hampshire was induced to do what is called "conservative lumbering"; that is to say, not robbing the forest of all salable timber, but to leave some for future taking. They saw that was a good policy and treated one hundred thousand acres in that fashion; leaving the smaller sizes below a certain diameter. A fire came and swept over the ground and destroyed everything that had been left, and now there is one friend of forestry less.

I am glad to say that there are not any more of the mere economists and the sentimentalists interested in this question, but the lumbermen themselves. With their pocket-books interested, they will find the methods of protecting their forest property and they will insist that the function of the State, which first of all is to protect property, should be properly employed.

I do not know that I have been able to say anything that is new. All these things have been threshed out for the last twenty-four years at least, when the first 
Forestry Congress met, and perhaps before that time. There is nothing unknown, so far as I am aware, that would lead us to comprehend conditions better, and it is only necessary for us to put into practice what we know, TO DO, as was suggested this morning.

\section{Address by Mrs. L. P. Williams}

Chairman Forestry Committee, General Federation of Women's Clubs

I HAVE, not my resolution in my pocket, nor have I any greetings prepared, and am somewhat surprised to be called upon at this time; however, I will take the opportunity to say that it gives me much pleasure to sit in this meeting and see these many allied interests and forces drawing together, since coöperation means progress.

I am glad also to say that you recognize and permit women to have a share in your deliberations and be helpful in the work. Women have ever been recognized as conservators of the interests of the home, then why should they not assist in this particular work that contributes to the building of prosperous homes, which are the foundation upon which national prosperity is built?

The General Federation of Womens Clubs held its biennial convention in St. Louis last May, and seven days we sat in council-daughters from the South, where the great, wide-spreading paternal oak vies with the palm, magnolia, and acacia in casting its benign shade-sisters from the East, where maple, elm, and chestnut burst into varied green and glow and flame and mellow under autumn skies. Comrades from the North, where forest paths are carpeted with the fragrant needle of the fir and pine. Co-workers from the 
Rockies, Cascades, and Sierras, where the king of the larches, the Douglas spruce and the majestic Sequoias stand alone as sole survivors on the horizon of antiquity and speak of a past so remote that history makes no attempt to follow.

From each section of the country came the delegates, that as loyal daughters of this Republic they might consider those problems that stand closest to the nation's life and most affect her common weal. The seven days were crowded full of earnest thought and anxious desire to know how best to combat the forces of evil and dispel ignorance to the end that our land may be filled with prosperous homes and we be a virtuous and happy people.

Forestry we approached last as if to be reminded that back of the whirr of spindles, the infected air of sweat shops and the stiffling, vice-polluting atmosphere. of crowded tenements, after consideration of soulless corporations and corrupt party politics we should move back to nature and take comfort in the thought that in field and forest lies the nation's hope. The land policy and the forest policy of our country holds the key to the solution of many of the problems that vex the social economist of to-day. Henry Clay held, back in the fifties, that the land policy of the country will be a vital problem of the day after the tariff question has ceased to exist. We recognize in 1905 that he should have included its twin sister, the forest policy, which must go hand in hand with the land policy, as an essential part of it, if our valleys shall be watered and fruitful, our deep waterways be kept open and float our cargoes, and our waste land be utilized and Columbia's beauty be perpetuated.

I extend to this body fraternal greetings from that General Federation of Women's Clubs, eight hundred 
thousand strong, a great reserve force that is coming to your aid in forestry, although as yet you may regard us as the awkward squad. Forestry was added to our work only three years ago, but the committee questions if any department of the General Federation can show so great an increase of interest during the three years as in forestry. Thirty-eight States have, where it was not already a department of work, added work in forestry, and the committees are enthusiastically spreading the propaganda of tree-planting, forest preservation, and irrigation. Like a prairie fire, interest among State Federations in national and State movements for the preservation of large blocks of forest, is spreading and blazing up here and there from the cypress groves of California to the spruce clad slopes of New Hampshire.

Forestry as apprehended in our work covers both arboriculture and scientific forestry. A very general activity is manifest throughout the length and breadth of the country in arboriculture, or tree-planting for decorative purposes; parks, cemeteries, school grounds, highways and treeless plains in rural districts, towns and villages, are coming into their inheritance of beauty and beneficence through the grateful shade and presence in their-midst of oak and linden, larch and chestnut, palm and pine, as numerous instances in the State reports testify. Not always have the clubs taken the initiative, but all are actively coöperating, and in many cases are the originators of forestry movements.

The work of the Thursday Club of St. Paul deserves especial mention. The club last spring obtained the consent of the Board of Education to make an appeal, through the teachers of the public schools, to the children to purchase and plant fruit trees on Arbor Day, which the club agreed to furnish at small cost. The 
Park Commission coöperated and allowed each child who desired to plant his trees in one of the city parks to do so, and tag it with his name. The result was the purchase and planting of 14,000 fruit trees by the children.

In the San Diego District of California, out of twenty-six clubs, nine have taken up the study of forestry: Three have been tree-planting, and the San Diego Clubs have raised $\$ 5,000$ to improve their I, 400 acre park. Beaufort, S. C., reports twenty-five miles of clear hard-shell road, generously provided with young shade trees, and a Delaware club has planted an avenue of trees one mile long, reaching from one town to another. The Massachusetts clubs are giving valuable assistance in fighting the brown tail and gipsy moth. The wômen of Salem have aroused public interest and the children have gathered and burned 375,000 moth nests, and adjacent towns are following Salem's example. Salem's latter-day burnings are to be commended!

A member from Minnesota said to me, "You women had so much to do with the repeal of the "Dead and Down Timber Act,' under which the Chippewa Reserve was administered prior to the application of the Morris law, that you ought to tell, sometime during the Congress, the story of finding the lamp, to show how trees were brought under the 'dead and down' provision." To make sentiment for the repeal of the bill the Minnesota club women planned an excursion to Leech Lake, which is within the reserve. The lumbermen in Minnesota are not all converted to conservative forestry, and gallantry sometimes is forgotten when "so many board feet measure" enter into the proposition. Our party numbered about fifty, and included Miss Dock, a member of the Pennsylvania Forestry 
Commission, who is a delegate to this convention. There were two available steamers on the lake that were very good, and one poor old house-boat. The manager had chartered the steamers for our use; imagine our surprise on arriving to learn that the night before the boiler of the best steamer had been scuttled and put out of use and at daybreak the other steamer was seen scudding off down the lake. A latunch was sent flying after the steamer, and it was finally hailed and the captain asked to explain where he was going, and why he had broken faith with the ladies. "Oh," he replied, "a lumberman down the lake has engaged the steamer for a week."

Fortunately, a boiler inspector reached the town that morning, special providence you know, and resenting such ungallant treatment of the ladies, declared if it was possible the boat should be put in repair and be ready for use the following morning. Blacksmiths, plumbers and carpenters, all lent a hand, and by noon the following day the party was able to go aboard.

Our forestry friend from Pennsylvania was anxious to see the character of the second growth on the reserve, and seeing a bold bluff at that point, and with Father Wright, chief of the Chippewas and missionary at the agency for forty years, to act as guide, we made a landing.

Our astonishment can be imagined when we found each one of those beautiful old virgin pines burned at the root, just enough to bring it under the condemned list. Unfamiliar with the vicious workings of the dead and down law, we looked about to learn the cause of the fire. Not a leaf, twig, or grass blade was scorched, there was no sign of tramp or camper, but on examining the burning in the noblest tree of all the group we discovered a small kerosene lamp almost melted down. 


\section{AMERICAN FOREST CONGRESS}

Father Wright sat at a little distance looking out at the blue waters of the lake over which for centuries the birch canoes of his people had glided so swiftly. We approached, and holding aloft the lamp, said: "What does this mean?" With a pathos in his voice that I shall never forget, he replied, "Dead and Down Timber Act, burn, want to buy."

I assure you the old lamp was good campaign material. At our next State meeting, when our brothers were present, we told the story and exhibited the lamp and said, "Are not the Indians the wards of this nation? Shall we, through our laws, offer a premium for criminal practices? This lamp should cause blush of shame to mantle the cheek of every honest voter in Minnesota and kindle a back fire of indignation that should wipe from off the statutes such nefarious laws.

It is true, women do not vote, but who shall say that they are actually "counted out?" Let me illustrate that we have a little influence, by another incident in our forest reserve campaign. When the stress came, and the news reached us that some of our Minnesota members in Washington had gone over to the enemy, the club women concluded it was desirable to send representatives to interview our Congressmen. On reaching Washington, we first sent our cards to a member with whom we had a personal acquaintance, and were received most graciously with this greeting, "When did you arrive, how did you leave my constituents, and what can I do to enhance the pleasure and profit of your visit?" But as soon as we mentioned the forest reserve the atmosphere seemed suddenly struck by a nor'easter and the mercury fell as quickly as at Chilkoot Pass, and in icy accents these words fell upon our ears: "Well, ladies, I'm not much interested in that forest reserve scheme, and I don't 
think my constituents are!" We replied are we not your constituents? "Oh, yes, of course, I want to please the ladies," he answered, and triflingly added, "but you know the mosquitoes are too thick!" Disregarding his trifling remark, the women of Minnesota are desperately in earnest in this matter. We represent the State Federation of Women's Clubs, which has a membership of between six and seven thousand, and you know that six or seven thousand women represent collectively six or seven thousand husbands and a few thousand sons, who will possibly vote as their fathers vote. We grant you, the mosquitoes are thick, but they could hardly disable you for your Congressional duties, but beware of setting six or seven thousand bees buzzing in women's bonnets. And, strange to relate, the mercury began to rise until the atmosphere was quite tropical.

Some two weeks later, having retired from the field, we dared to send a batch of petitions to this same member, and received this gracious answer: "Yours at hand, petitions submitted to the House and referred to the Committee on Public Lands, and I desire to assure you, if I can advance the interests of the forest reserve movement in any way, command my services at any time."

Do not think our interview with the member was intended to savor of intimidation. We simply stated facts and gave a little kindly information. You know a woman has no "axe to grind," she just speaks out what is in her heart, and so sometimes it carries weight-being a club woman, of course it carried weight.

I desire to say, in closing, that the passage of a bill to increase the Navy of the United States, finds many friends, and is an easy proposition compared with 
securing an appropriation for a forest reserve, for you see there isn't anything in the latter for anybody except the people. While, for the former you can "line up" a solid phalanx of shipbuilders, armor plate, and boiler makers and all their henchmen to bear down upon our Congressmen with silver-tipped arrows and promissory appeals that win. We foresters work for the people, and so oftimes our arguments and bills have to wait a long while before they are given a hearing and penetrate the crust of human selfishness.

\section{Address by Filibert Roth}

Pxofessor of Forestry, University of Michigan

I CAME here as an individual to enjoy meeting friends and gather inspiration which will enable me to perform better my duty as a citizen, as a servant of the Michigan Forestry Commission, and as a teacher at the University. I also came here as the servant of that Commission, representing it, I am afraid, very poorly. I came here to say to you that Michigan is still in the front ranks of this union as one of its greatest States. For nearly a century we in Michigan have been hewing out of the forests the homes for more than two million people, our lumbermen have hustled, and have provided the lumber to build the homes of the prairie States from the Dominion to Texas. We worked faster than we knew. Had we continued with the ox team and the old-time "up and down" sash saw, we would still have pine to sell. But the old methods were too slow; the old-fashioned "cog gear" gave away to "rope feed," and rope feed was thrown away and replaced by "shotgun" feed to rush the timber against the whirling saw.

Working with steam and electricity we went beyond 
our proper mark, and for years it seemed as if the signs of the times would remain unheeded. And many of us began to wonder what the matter was with our State of Michigan. The people of the Dominion, our neighbors, were awake, and introduced better methods; the older States had gone ahead, and, realizing that they, too, had gone too far, had begun to check the damage and prepare for its correction; but we in our State were still going the swift pace of slaughter and destruction. Were we to be behind? No. I have come to say to you that Michigan is not behind the rest of the States. We were merely too busy to realize just where we were. Michigan has awakened to the importance of doing; she has begun to check the evil, she is organizing to repair the damage. Michigan has a Forestry Commission, which looks after the forest interests of the State; it has begun a proper land policy and established the nucleus of a State forest, and is training its boys in the care of the woods at its two great institutions, the University of Michigan, and the Agricultural College. The business men of every city in the State are united in a desire-even demandthat something be done and done at once, to check further timber devastation and to restore to the State the supply of material so necessary for its welfare. We have with us the people, even the women of our State have taken up the matter of forestry, and that great factor of civilization, civic and social improvement, the Federation of Womens Clubs of Michigan has begun a systematic, well directed campaign in favor of State and private forestry. We are moving, and our path is clearly before us, and our opportunities are as good as those of any State in the Union. It gives me great pleasure to tell you of this, and to say that Michigan is here with you, and stands ready to coöperate with its sister States in this great movement. 


\section{Address by Dr. C. A. Schenck}

\section{Director, Biltmore Forest School}

$\mathrm{M}^{\mathrm{Y}}$ connection with forestry in western North Carolina is of a three-fold character: I am a lumberman, a forester and a teacher.

I am a lumberman, and I must confess to being somewhat afraid as a lumberman to appear before this audience. Still, while in charge of a large forest in western North Carolina, I cannot help being a lumberman. Without lumbering no cash dividend is obtainable from forest investments. Therefore, I cut the trees, though I can truthfully add that I do not cut all the tree-for the reason that it pays better not to cut all of them, under the conditions now prevailing in western North Carolina.

We are just beginning a new year, and, as new year's wishes are in order, I wish that every one of you were possessed of 50,000 acres of hardwood lands in the Appalachian range! If you were the owners of such timber tracts in our mountains, or anywhere in the East, what would you do with the timber? I ask your conscience, would you let the timber stand, or would you convert that timber, all of it or part of it, into money? We are in the habit of blaming the other fellow for cutting the trees. Now, pardon me when I ask: What would you do with the trees if you owned them?

Secondly, I am a forester, and as a forester I am meant to raise trees, partly by planting, partly by lending Nature a helping hand. The owner of the Biltmore estate, without doubt, would authorize me to practice more silviculture if he could consider silviculture (the raising and tending of a second growth) a remunerative investment; I had better, perhaps, say a safe and remunerative investment. 
However, as fires annually rage over large sections of our grounds, it is hazardous-nay! it is almost folly-to invest money in silvicultural pursuits. At Biltmore we are forced to restrict reforestation to such regions in the proximity of Biltmore House in which we can control fires absolutely. In a large primeval tract covering 120,000 acres of backwoods, absolute fire protection is out of the question. Here I do not attempt to enforce regeneration, simply allowing $\mathrm{Na}$ ture to do the work as best she can, trying at the same time to protect the second growth from fire wherever it appears.

Foresters are very frequently, I think, of the opinion that the little trees-second growth-are really the best money makers. Foresters working in the Appalachians might just as well begin to change their minds. The fact has been pointed out to-day repeatedly that the price of hardwood stumpage is increasing rapidly. If that is true, the big tree is the best money maker, and really mature trees do not exist-moribunds excepted-where and as long as the price of stumpage advances rapidly.

In 1896 I sold many a fine white oak at fifty cents per thousand feet, board measure. I wish I could replace these trees. I would gladly put them back in the woods at $\$ 4$ a thousand-because they are worth now $\$ 5$ a thousand. In I898 I got for similar trees $\$ 1.25$ a thousand feet, board measure; in 1902 I received $\$ 2.50$, and last year I found a man who was willing to give me as much as $\$ 8$ per thousand!

Thus it happens that the big trees-the three, four, five and six-footers-are my pride, more so than the seedlings and saplings. I hold the big giants dearly; I refrain from cutting them-merely for the reason that they are my best money makers, the best part of my investments-and also the safest part of my invest- 
ments since they are not subject to destructive forest fires. So much for the forest.

Finally, I am the director of the Biltmore Forest School, established at Biltmore, North Carolina, in r898. I am delighted, though it makes me feel old, to see so many of my. former pupils present in this hall. Permit me to use this chance for reminding them forcibly of my old demands and unceasing teachings-so often repeated with the regularity of a canary bird or of a whippoorwill-keep constantly before your eyes the fact that forestry subserves lumbering, that forestry is lumbering to a very large extent.

Silviculture and lumbering together will, I think, compose the work of the forester in this country for many a year to come. The greater portion of practical wood's work will lie in the line of lumbering, and the lesser part will consist of silviculture merely because silviculture is not as safe an investment at present, nor is it as remunerative as lumbering.

The time will come when the reserve will be the case. It will come when the superiority of conservative lumbering over destructive lumbering is clearly evidenced by the larger number of dollars which conservative lumbering can draw as a dividend from the forest.

\section{Address by Rutherford P. Hayes}

President, The Appalachian Forest Reserve Association

$S O$ far most of the discussions here have related to the extreme West. The problems that they are working out there we have with us in the Southern Appalachians. The effect of destroying the forests and filling up the rivers is comparable with what is going on now on the eastern slope of the Blue Ridge 
Mountains. The rivers running from there through North Carolina, South Carolina and Georgia used to be all clear mountain streams, and in times of flood there was simply a flow of water and after it passed away that was the end of it. Now they have their times of higher flood and their times of greater drought and the river beds and mill dams are all being ruined by the silt that is washed down. We seem to have a very much more fluid soil when it gets wet than a great deal of that we have in the North, and the extent of this destruction is becoming apparent all through the South. On the Catawba River what were a few years ago good farm lands are now covered with eight, ten, or twelve feet of sand and gravel. Two years ago there was a flood along the French Broad River and the destruction was very great. It reached Knoxville, and it was the first time that anybody in Tennessee had become interested in the preservation of these forests.

We have standing on the Appalachian Mountains, the Blue Ridge and the great Smoky ranges from southern Virginia through to northern Alabama, the last remains of the hardwood forests of the East. The Blue Ridge is pretty well cleared. We have been trying, through our Appalachian Forest Reserve Association, to create an interest in Congress that would save the balance of this country from being cleared. Congress has appropriated over four and one-half million dollars in the past three years for the improvement of the rivers in this section, and unless these forests are preserved, most of this money is wasted. The Great Smoky range, the boundary line between North Carolina and Tennessee, has been inaccessible as compared with the Blue Ridge, and is little cleared. I do not know how much you know of the particulars of that country. We have as rough mountains as they have in 
the Rocky Mountains. We have what they had years ago, mountains covered with forests. We are getting to have what they have now, bare mountains. The illustrations that are being given of the Rocky Mountains and the results that are going on there, we can see in all its different states, and we are anxious to have our friends help us to try and save this great region. Looking at it from the economic point, it means the saving of water power, and the transportation of the entire South, from where the Tennessee River enters the Ohio, to the south and east clear around to the Potomac River.

I have prepared a resolution on the subject of forest reservation and will present it to the Resolutions Committee. We want to have the Government buy this tract of land in the Great Smoky Mountains, the boundary between North Carolina and Tennessee, about two hundred miles long and from twenty to forty miles wide, and control it as the forest reserves in the West are controlled. If any one within that territory wishes to retain his property and will manage it on proper forest plans, there will be no reason for interfering with him. There will be rights of way through the forest reserve the same as has been mentioned for the West. This reserve will be within twenty-four hours' ride of three-fourths of the population of the United States, and would be available as a pleasure ground for a large proportion of our country. Of course the Yellowstone Park is the park of the United States, but a forest reserve in the Southern Appalachians, which could be used as a pleasure ground as well, would be of much more immediate interest to our people than one so far away as the other. As I said before, I will prepare a resolution and give it to our Resolutions Committee and hope for your favorable support. 


\section{Address by Mr. Elihu Stewart}

Superintendent, Forestry Branch, Department of the Interior, Canada

I HAVE listened with a great deal of pleasure indeed to the various addresses that have been made, and above all, I think all who have come from across the lines and all who have come from this side of the lines, cannot help but be wonderfully impressed with the magnificent address that President Roosevelt gave us yesterday.

I have heard a good deal about your system of work, and $I$ am in position to know what your Bureau of Forestry is doing, because I get all its bulletins. But above all, with such a President as you have, with such a head of the nation as you have, and with such an administrator as you have in $\mathrm{Mr}$. Pinchot, I feel that there is a guaranty above all others that your forestry matters will be looked after in the future, and that you will progress in the lines that Mr. Pinchot has so admirably pointed out as the direction he intends to give the interests of forestry matters in the United States of America. I am not going to say a word about our system across the line. My friend, Mr. White, has, I think, done that sufficiently, and more in that line would not be interesting to you, except this:

It has only been about five years since I undertook, in a very feeble way, to organize the forestry service for the Federal Government in Canada. Shortly after starting the work, I wrote to my friend Pinchot and told him I was anxious to learn of the workings of the Bureau here, and asked him if he would be kind enough to let me know when he thought would be best or most convenient for me to come here and endeavor to get information as to the workings of his Bureau 
in this country, which had been in operation for some little time. He replied that he thought the best time would be when the meeting of the American Forestry Association was being held. So I came over-I think it was five years ago-and on my return-I think somewhere between here and Baltimore-I was alone on the train. I went into the smoker, and I think there must have been inspiration there-it isn't often I have inspirations, and don't believe I ever had one before that resulted in anything, but this one did-for it occurred to me, why could not we have a Canadian Forestry Association? Once the thought flashed across my mind I knew that we could; and I want to say that as a legitimate offspring of that inspiration and his association in the United States, we have a most successful one in Canada. Not so much on account of the numbers-we have only about six hundred members as yet-but it is the personnel. We found that the best people in the country were just waiting for an opportunity to express their views collectively and at once. We got together a committee formed governors, ex-governors, senators, and influential men in every part of the Dominion, commencing in Prince Edward Island, where we have one of the most active men, through Nova Scotia, New Brunswick, and every district in the great Northwest-even the Yukon. Every district is represented. And without taking up your time-as I know I must not do so-I wish to say that we are having a meeting in the old city of Quebec on the IIth of March-a meeting of that association, and I want to invite every one who can come from this side of the line to come over at that time and make us a visit.

One thought more occurs to me. We have a fire ranging system in the West similar to yours in the reserves. I was away out in Alberta, near the Priest 
River Reserve, and two of the rangers came over while I was at a little town called Cardston. I think perhaps it was their practice to come over there on Saturday nights. They were in the hotel, discussing international matters-the boundaries. I had to go back about eleven o'clock at night in order to start in the morning, and about that time the discussion was becoming very animated. I hope it has been decided. I simply say that in order to show how closely the people out there along the boundaries are related. And as being of interest to the people of Washington and Oregon, I wish to say that we are doing all we can to guard the timber upon the upper reaches of the Columbia River, which, as you know, has its rise in British Columbia and finally finds its outlet at Astoria, and we shall continue to do our part so far as our limited means will permit.

\section{Address by Mr. G. O. Shields}

\section{President, League of American Sportsmen}

I REPRESENT the League of American Sportsmen, which has a membership of 10,700 men and women, distributed throughout every State and Territory of the Union, also largely in Canada and Mexico. As every man who has ever thought of the subject knows, the causes of game protection and forest protection go hand in hand. Whatever you ladies and gentlemen do in the interest of preserving the forests you do as well in the interest of preserving the wild life of this country, and we claim that is a subject worthy the attention of all earnest men and women.

We have two important measures before Congress to-day, on which we need the assistance of this Con- 
gress. One of these concerns especially the Territory of Oklahoma, of which my friend has just spoken. The Wichita Forest Reserve was created some years ago, and Congressman Lacey, of Iowa, introduced a bill at the last session to erect that forest reserve into a game preserve, for the purpose of propagating quail, prairie chickens, wild turkeys and deer, and then shipping them to the Northern and Eastern States, where they have been exterminated or nearly so.

The other measure affects all the forest reservations. It aims to empower the President of the United States to set aside certain sections in forest reserves already created, to be known as game preserves; to stop all shooting thereon and, if necessary, all fishing; to let the game have a few asylums in these mountain regions where it can live and increase.

Every man and woman in this audience knows what a wonderful success has been made in the Yellowstone Park, in preserving the wild animals there. Mr. Lacey told me to-day he had just seen photographs from the park showing 500 antelope grazing, some of them in the streets of Gardner, a town five miles outside the park. There are supposed to be 30,000 or 35,000 elk in the park. There are about forty buffaloes, several hundred Rocky Mountain sheep and many thousands of deer.

I want to impress on your minds these important facts that are associated so intimately with the cause of forest preservation. The object of setting aside these forest reserves, the primary object, is to preserve trees; the secondary object, the important one of the association I represent, is the preservation of wild animals and birds. We are working as industriously for the preservation of insectivorous and song birds as we are for the game birds. 
Another thing I desire to call attention to, and on this point I shall present a resolution when the time comes. It is the disastrous and alarming destruction of our forest for the purpose of making paper. We must all have our reading matter, and the problem of supplying wood pulp for the making of paper is a serious one. I do not know whether it is to be taken up in this Congress or not, but it certainly should be considered. I want you to ask Congress to offer a very generous reward to any person who will devise or discover a method of making pulp, and from that paper, from any product that farmers can raise on their farms every year. It seems to me this is a very important subject for this Congress to consider.

\section{Address by Mr. Charles L. Pack}

THERE is little I can say to edify this Congress. I am simply a plain owner of trees, of forest lands in different parts of the country. I have taken great interest in this subject for many years, and I may say also that I have learned a great deal this week in Washington. I have studied the commercial side of forestry at home and abroad, and I have come to believe that the man who cuts down a tree should plant or cultivate or care for two new ones. Our economic laws should make it an inducement for him to do so. We must do something to catch up, as we have been very tardy in applying what experience teaches on this subject. The problem of private forestry is a great one. I am caring for, at present, several thousand acres of small timber in different parts of the country, but I am faced with the taxation question; 


\section{AMERICAN Forest CONGRESS}

and I think one of the greatest questions of forestry within the States having to do with the private ownership of the forest and the promotion of forestry locally, is the taxation question. Much baby timber is cut because its owners can't pay exorbitant taxes. I will not detain you by giving my ideas at this time upon the subject, but I think an equitable State taxation scheme can be devised with the aid of those present. I believe that the time is long past when the Government should, through the operation of any law, sell or dispose of timber by the acre, but that every tree disposed of should be under the direction of the Forest Service, and be sold by the thousand feet. And, I believe, further, that while in years past our forefathers cut the trees of the forest without leave or hindrance, that now we all readily see that no man has a private right to the timber on public lands without paying a full consideration. Under our present laws much timber is annually obtained, and at a fraction of its actual value. And, I believe, that the same is true with regard to the use of the forest reserves by the stockman, by the sheep raiser and the cattle raiser. I think the time is at hand when they should pay a small, but equitable and just charge for the use of the ranges. 


\section{RESOLUTIONS ADOPTED BY THE AMERICAN FOREST CONGRESS}

Resolved, That we urge upon Congress and upon all legislative bodies the necessity at all times of giving full protection to the forests of the country and of preserving them through wise and beneficent laws, so that they may contribute in the most complete manner to the continued prosperity of the country.

Resolved, That we earnestly commend to all state authorities the enactment and enforcement of laws for the protection of the forests from fire, and for reducing the burden of taxation on lands held for forest reproduction in order that persons and corporations may be induced to put in practice the principles of forest conservation.

Resolved, That we are in entire accord with the eforts to repeal the Timber and Stone Act, and we favor the passage of an act as a substitute therefor which shall confer authority upon the proper officer of the United States to sell timber growing on the public lands when such sale shall be for the public welfare.

Resolved, That we favor the passage by Congress of an amendment to the law regarding exchange of lands included within a forest reserve so that such exchanges or lieu selections shall be confined to lands of equivalent value or similar condition as regards forest growth.*

Resolved, That the law which prohibits the export of forest reserve timber from the state in which it is grown should be repealed as to the states in which the export of such timber is in the public interest, and in no others.

*Lieu land law was repealed. 
Resolved, That we favor the passage of a law which will authorize the sale of all non-mineral products of the forest reserves, the proceeds of such sales to be applied to their management and protection, and the construction of roads and trails within the forest reserve.

Resolved, That we heartily approve the movement for the unification of all the forest work of the Government, including the administration of the National Forest Reserves, in the Department of Agriculture, and urge upon Congress the necessity for immediate action to that end.**

Resolved, That Congress declare forfeited all right of way permits not exercised promptly upon issuance, and secure to all industries engaged in lawful business, and which will exercise promptly their permits, the possession of necessary rights of way, in the same manner that railroads and irrigating companies are secured in their rights of way, and that the various right-of-way acts on forest reserves and other public lands be so amended as to provide for reasonable payment for the use of these valuable rights.

Resolved, That this Congress urges upon all schools, and especially the rural schools, the necessity for a study of forests and tree-planting in their effect upon the general well-being of the nation, and in particular upon the wealth and happiness of communities through the modification of local climate; and that we urge all state legislatures to provide laws and financial aid to consolidate the rural schools in units sufficiently large that forestry, agriculture, and home economics may be successfully taught by precept, example, and practical work.

**Passed by Congress and signed by President Roosevelt February I, 1905. 
Resolved, That this Congress recommends the increase of opportunities for general forest education in schools and colleges, and for professional training in post-graduate schools; and approves the movement to extend and systematize industrial education in the interest of a more general distribution of the population on the land.

Resolved, That the Congress of the United States be asked to appropriate adequate sums for the promotion of forest education and forest experiment work in the agricultural colleges and experiment stations of the United States; Provided, however, such appropriations be made directly to state forestry departments, bureaus, or commissions, where existing, to be used in their respective states as may seem best for forestry educational purposes.

Resolved, That this Congress approves and reaffirms the resolutions of various scientific and commercial bodies during the past few years in favor of the establishment of national forest reserves in the Southern Appalachian Mountains and in the White Mountains of New Hampshire, and that we earnestly urge the immediate passage of bills for these purposes which are now pending in both houses of Congress.

Resolved, That we protest against the attempt to reduce the area of the Minnesota National Forest Reserve and against any step which would enhance the difficulty of the perpetuation of the forests upon it.

Resolved, That we heartily endorse the movement for the purchase of the Calaveras Grove of Big Trees by the National Government and earnestly recommend the prompt enactment of legislation to that end; and, further, we recommend the reconveying by the State of California to the National Government of the Yosemite Park in order that this may be adequately 
protected and placed upon the same basis as other national parks.

Resolved, That this Congress urges tree-planting and the preservation of shade trees along public highways throughout America.

Resolved, That we approve the suggestion that a tree be planted at Mount Vernon to commemorate the American Forest Congress, and that funds for this purpose be collected through Forestry and Irrigation.

Resolved, That as Oklahoma would immeasurably profit by increased land valuation resulting from greater crop capacity as the outgrowth of wind reduction; therefore, the territory should be empowered to offer school land occupants a reasonable realty tax reduction during a stipulated growing period of tree windbreaks; Provided, that the department of government under which the nation's forestry interests are managed shall outline, control, and perfect, in all particulars, determining how and to which lands the provisions shall apply, except that purchasers at the time of sale have option as to acceptance of these terms.

Resolved, That it is the sense of this Congress that the National Homestead Law should be amended so as to require the planting of at least 5 per cent of the area of a homestead before final title be acquired, and that the tree planting be under the supervision of the Bureau of Forestry. 


\section{LIST OF DELEGATES}

Adams, J. B., Washington, D. C. ; representing Bureau of Forestry.

Adams, Miss B. E., Washington, D. C. ; General Land Office.

Agar, John G., New York City; Society for Protection of the Adirondacks.

Agnew, Mrs. Kate L., Valparaiso, Ind.; State of Indiana.

Ahern, Capt. Geo. P., Manila; Forestry Bureau of Philippines.

Aitken, Geo., Woodstock, Vt.; Vermont Forestry Association.

Akerman, A. K., State Forester, Boston, Mass.; Massachusetts Forestry Association.

Allen, E. T., Forest Inspector, Bureau of Forestry, Washington, D. C.

Allen, E. W., Office of Ex. Stations, Department of Agriculture, Washington, D. C.

Anderson, A. A., New York City; Forest Reserve

Service and New York Chamber of Commerce.

Anderson, J. W., General Land Office, Washington, D. C.

Andrews, Byron, Washington, D. C.; American

Forestry Association from South Dakota.

Atkinson, A. L. C., Honolulu, Hawaii.

Ayres, Philip W., Forester, Society for Protection of

New Hampshire Forests, Concord, N. H.

Baily, Joshua L., Philadelphia, Pa. ; American Forestry Association from Pennsylvania.

Baird, Dan W., Nashville, Tenn.; Editor Southern

Lumberman. 
Baker, J. F., Bureau of Forestry, Washington, D. C. ; Saline Valley Telephone Company.

Ball, C. R., Washington, D. C.; Iowa Park and Forestry Association.

Barber, J. T., Eau Claire, Wis.; Mississippi Valley Lumberman's Association and Northwestern Hemlock Manufacturers' Association.

Barnard, E. C., U. S. Geological Survey, Washington, D. C.

Barns, W. E., St. Louis, Mo.; Editor St. Louis Lumberman.

Bartlett, J. H., Middleboro, Ky.; State of Kentucky. Becker, G. F., U. S. Geological Survey, Washington, D. C.

Beecher, F. R., Retail Lumber Dealers' Association, Canadaigua, N. Y.

Bell, Dr. Robt., Agricultural Department, Ottawa, Ontario, Canada; Canadian Forestry Association.

Bentz, Hon. P. J., Woonsocket, S. D.; State of South Dakota.

Berg, Walter G., Philadelphia, Pa.; Lehigh Valley Railroad system.

Berthrong, I. P., Washington, D. C.; General Land Office.

Bidwell, Geo. F. Chicago, Ill.; Chicago and Northwestern Railway Company.

Bein, Morris, U. S. Geological Survey, Washington, D. C.

Binford, L. M., Saco, Maine; National Association of Box and Box Shook Manufacturers of the United States.

Bitler, F. L., Philadelphia, Pa.; Pennsylvania Forestry Association.

Blades, J. B., Elizabeth City, N. C.; National Wholesale Lumber Dealers' Association and North Carolina Forestry Association. 
Blanchard, C. J., U. S. Geological Survey, Washington, D. C.

Bliss, Geo. Hl Spokane, Wash.; Reclamation Service. Blodgett, James H., Washington, D. C.; American Forestry Association.

Bogue, Prof. E. E., Michigan Agricultural College, Agricultural College P. O., Michigan.

Bond, Frank, General Land Office, Washington, D. C. Borst, Theo. F., Clinton, Mass.; American Forestry Association from Massachusetts.

Brooks, Hon. F. E.., Colorado Springs, Colo.; State of Colorado.

Bowers, Edward A., New Haven, Conn.; Connecticut Forestry Association and American Forestry Association.

Brooks, A. H., U. S. Geological Survey, Washington, D. C.

Bruce, E. S., Bureau of Forestry, Washington, D. C. Bruce, Grant, Bureau of Forestry, Washington, D. C.; American Forestry Association.

Bulllock, Capt. Seth, Deadwood, S. D. ; South Dakota Forest Reserve Service.

Bunker, Wm. M., Washington, D. C. ; Chamber of Commerce of San Francisco.

Burkholder, S., Crawfordsville, Ind. ; National Wholesale Lumber Dealers' Association.

Burton, P. G., Chesapeake and Potomac Telephone Company, Washington, D. C.

Campbell, R. H., Secretary Canadian Forestry Association, Ottawa, Ontario, Canada.

Candland, W. D., Mt. Pleasant, Utah; Utah Wool Growers' Association.

Cary, Austin, Brunswick, Me.; American Forestry Association from Maine.

Chapman, C. S., Bureau of Forestry, Washington, D. C. 
Chapman, Herman H., Bureau of Forestry, Washington, D. C. ; American Forestry Association.

Charlton, R. H., Denver, Colo.; Forest Reserve Service.

Chittenden, A. K., Bureau of Forestry, Washington, D. C.

Chown, C. Y., Queen's University, Kingston, Ontario, Canada.

Churchill, C. S., Roanoke, Va.; Norfolk and Western Railway.

Clark, C. C., Washington, D. C. ; Department of Agriculture.

Clark, Hon. Clarence D., U. S. Senate, Washington, D. C.; State of Wyoming.

Clark, Dr. J. F., Department of the Interior, Ontario, Canada; Ontario Bureau of Forestry.

Clark, Dr. Wm. B., State Geologist, Baltimore, Md.; State Geological and Economic Society.

Clarke, S. A., General Land Office, Washington, D. C. ; State of Oregon.

Clement, G. E., Bureau of Forestry, Washington, D. C.; American Forestry Association.

Cleveland, J. F., Chicago, Ill.; Chicago and Northwestern Railway.

Clothier, Geo. L., Bureau of Forestry, Washington, D. C.

Cochran, Geo. G., New York City; Errie Railroad Company.

Cone, Albert B., Chicago, Ill.; American Lumberman. Conklin, Robt. S., Harrisburg, Pa.; Pennsylvania Forestry Association and Forestry Commission.

Cooke, Chas. B., Richmond, Va.; State of Virginia.

Cooper, Thomas, St. Paul, Minn.; Northern Pacific Railway Company.

Cosgriffe, T. A., Cheyenne, Wyo.; Northern Pacific Railroad. 
Coville, F. V., Washington, D. C.; American Forestry Association.

Cox, Wm. T., St. Anthony Park, Minn.; Minnesota State Forestry Association.

Craft, Q. R., Washington, D. C.; American Forestry Association from Kansas.

Craig, A. R., Mesa, Colo. ; Forest Reserve Service.

Crawford, C. G., Washington, D. C.; American Forestry Association.

Crenshaw, R. C., Frankfort, Ky.; State of Kentucky.

Curtin, Gen. G. W., Sutton, W. Va.; State of West Virginia.

Craig, D. A., Washington, D. C. ; Washington Evening Star.

Crenshaw, A. P., Chesapeake and Potomac Telephone Company, Washington, D. C.

Croft, A. J., Enosburg, Vt.; Vermont Maple Sugar Makers' Association.

Cutler, J. H., Raleigh, N. C. ; State of North Carolina. Davant, T. S., Roanoke, Va.; Norfolk and Western Railway Company.

Davis, L. G., Saratoga, Wyo.; Wyoming Forest Reserve Sc+vice.

Daw, N. L., Roanoke, Va.; Norfolk and Western Railway Company.

Daish, John B., Washington, D. C.; National Hay Association.

Davis, A. P., U. S. Geological Survey, Washington, D. C.

Deale, J. T., Chairman North Carolina Pine Association, Norfolk, Va.

Deering, Hon. Frank C. Bedford, Me.; State of Maine. Defebaugh, J. E., Chicago, Ill.; Editor American Lumberman.

Dezendorf, Mr., General Land Office, Washington, D. C. 
Dickinson, L. F., Greenfield, Mass. ; National Association of Box and Box Shook Manufacturers of the United States.

Dill, Lewis, Baltimore, Md. ; National Wholesale Lumber Dealers' Association.

Dixon, Hon. J. M., Washington, D. C.; Montana Stock Growers' Association.

Dock, Miss Mira L., State Forestry Commission, Harrisburg, P.a.

Donnelly, J. W., General Land Office, Washington, D. C.

DuBois, C. I., General Land Office, Washington, D. C.

Durgin, Jno. C., Sandy Hill, N. Y.; Forest, Water Storage and Manufacturing Association.

Drummond, A. T., Toronto, Canada; American Forestry Association.

Eaton, Hon. Geo. H., Calais, Me.; State of Maine.

Eberlein, Chas. W., Southern Pacific Railway.

Eddy, J. R., Washington, D. C.; National Geological Park.

Edmands, J. Rayner, Boston, Mass.; Massachusetts Forestry Association.

Elliott, Howard T., St. Paul, Minn.; President Northern Pacific Railway Company.

Elliott, S. B., State Forestry Commission, Harrisburg, $\mathrm{Pa}$.

Emerson, Col. Geo. H., Hoquiam, Wash. ; Pacific Coast Lumbermen.

England, Charles, Washington, D. C.; National Hay Association.

Faull, J. H., University of Toronto, Canada.

Fellows, A. L., U. S. Geological Survey, Washington, D. C.

Fenn, Maj. F. A., Kalispell, Mont.; Montana Forest Reserve Service. 
Fernow, Dr. Bernhard E.,, Ithaca, N. Y.; American Forestry Association from New York and Society for Protection of the Adirondacks.

Fimple, J. H., General Land Office, Washington, D. C. Fischer, Fred C., Tryon, N. C.; National Lumber Manufacturers' Association.

Fisher, Prof. Richard T., Harvard University, Cambridge, Mass.

Fisher, Wm. H., Cincinnati, Ohio; State of Ohio. Fitch, C. H., U. S. Geological Survey, Washington, D. C.

Fletcher, Dr. Jas., Ottawa, Ontario, Canada ; Canadian Forestry Association.

Foley, John, Bureau of Forestry, Washington, D. C. Foster, H. D., Washington, D. C. ; American Forestry Association.

Foster, N. C., Wisconsin Hardwood Iumbermen's Association, Fairchild, Wis.

Fowler, Hon. B. A., Phoenix, Ariz.; Territory of Arizona.

Fox, Col. Wm. F., Superintendent of State Forests, Albany, N. Y.; Association for Protection of Adirondacks.

Franklin, Blake, General Land Office, Washington, D. C.

Freeman, Miss Harriet E., Boston, Mass., American Forestry Association from Massachusetts and Massachusetts Forestry Association.

Freeman, Hon. Wm. F., State Forester, Indianapolis, Ind. ; Indiana State Board of Forestry.

Fulton, John, State Forestry Commission, Harrisburg, $\mathrm{Pa}$.

Gannett, Dr. Henry, U. S. Geological Survey, Washington, D. C. ; Sierra Club.

Gannett, Miss Mary C., Bureau of Forestry, Washington, D. C. ; American Forestry Association. 
Gardner, W. A., Chicago, Ill.; Chicago \& Northwestern Railway.

Gardner, Wesley J., Bureau of Forestry, Washington, D. C.

Garrett, Robt., Baltimore, Md. ; Delegate-at-large from Maryland.

Garver, L. J., General Land Office, Washington, D. C. Gaskill, Alfred, Bureau of Forestry, Washington, D. C. Gennett, Andrew, South Carolina; State of South Carolina.

Gibson, Edgar, Clyde Park, Mont.; State of Montana. Gilbert, Dr. G. K., Sierra Club, San Francisco, Cal. Gilfry, H: H., Washington, D. C. ; State of Oregon. Gillenwaters, E. P., Glascow, Ky.; State of Kentucky. Girtanner, Jules, Linden, N. J.; American Forestry Association.

Goddard, Hon. Albert J., Tacoma, Wash.; Tacoma Chamber of Commerce.

Gosney, E. S., President Arizona Wool Growers' Association, Flagstaff, Ariz.

Green, Dr. Samuel B., St. Anthony Park, Minn.; State of Minnesota and Minnesota State Forestry Association.

Green, Prof. W. J., Agricultural Experiment Station, Wooster, Ohio; State of Ohio.

Grier, T. J., Superintendent Homestake Mining Company, Lead, S. D.

Griffith, E. M., Madison, Wis. ; State Forest Service.

Grimes, E. P., Maine; State of Maine.

Grinnell, Henry, Bureau of Forestry, Washington, D. C.

Griswold, W. T., U. S. Geological Survey, Washington, D. C.

Grosvenor, Gilbert H., Washington, D. C.; American Forestry Association. 
Grunsky, C. E., Washington, D. C.; State of California.

Gwinn, J. H., Pendleton, Ore.; Oregon Wool Growers' Association.

Haas, L. G., Baltimore, Md.; Baltimore and Ohio Railroad.

Hagenbarth, F. J., National Live Stock Association Denver, Colo.

Haines, A. S., Westtown, Pa.; Pennsylvania Forestry Association.

Hale, Dr. Edward Everett, Washington, D. C. ; State of Massachusetts, Massachusetts Forestry Association, Appalachian Mountain Club.

Hall, Edward Hagaman, New York city; Association for Protection of the Adirondacks.

Hall, Geo. F., Chicago, Ill.; Chicago-Texas L. and L. Co.

Hall, James B., Clay City, Ky.; Beer Stock Manufacturers' Association.

Hall, Wm. L., Bureau of Forestry, Washington, D. C. ; Hawaii Forestry Service.

Hansen, Prof. N. E., Agricultural College, Brookings, S. D. ; State of South Dakota.

Happy, H. W., General Land Office, Washington, D. C.

Harrison, W. F., Norfolk, Va.; North Carolina Pine Association.

Harvey, Wm. S., Phildelphia, Pa.; Pennsylvania Forestry Association.

Hawes, Austin F., State Forester, New Haven, Conn. Hawley, R. C., Amherst, Mass.; American Forestry Association from Massachusetts.

Hayes, C. W., U. S. Geological Survey, Washington, D. C.

Hayes, R. P., Asheville, N. C. ; State of North Carolina. 
Henry, Alfred J., Washington, D. C. ; American Forestry Association.

Henry, H. D., Athens, Ohio; Union Association of Lumber Dealers.

Herndon, T. H., General Land Office, Washington, D. C.

Hightower, Clement, Capitan, N. M.; Territory of New Mexico.

Higgins, S. M., Forester, Cleveland-Cliffs Iron Company, Negaunee, Mich.

Hinshaw, G. W., President Stone Mountain Railway Company, Winston, N. C.

Hobbs, Jno, E., North Brunswick, Me.; American Forestry Association.

Hodge, Wm. C., Jr., Bureau of Forestry, Washington, D. C.

Hodson, E. R., Washington, D. C.; Iowa Park and Forestry Association.

Holcombe, E. P., General Land Office, Washington, D. C.

Holdredge, G. W., Chicago, Ill.; Chicago, Burlington and Quincy Railway Company.

Holmes, J.; State of Connecticut.

Holt, W. A., Oconto, Wis.; Northwestern Hemlock Manufacturers' Association.

Holter, Norman, Helena, Mont.; State of Montana.

Hoover, T. I., Carlisle, Pa.; Pennsylvania Forestry Association.

Hopkins, Dr. A. D., Washington, D. C. ; American Forestry Association.

Hotchkiss, Geo. W., Chicago, Ill. ; Lumber Secretaries' Bureau of Information.

Hoyt, Colgate, New York city; Missouri, Kansas and Texas Railway system.

Hutcheson, David, Congressional Library, Washington, D. C. 
Hutchinson, James, Randolph, Vt.; Delegate-at-large. Imes, R. P., Washington, D. C., American Forestry Association.

Irvin, Hon. Edw. A., Curwensville, Pa. ; State of Pennsylvania.

Irvine, Wm., Chippewa Falls, Wis.; Mississippi Valley Lumber Association.

Ivy, Thos. P., Conway, N. H.; State of New Hampshire.

Jackson, Luis, New York city; Erie Railroad Company.

Jastro, H. A., Bakersfield, Cal. ; Kern County Cattle Growers' Association.

Jenks, Robt., Cleveland, Ohio; Lumbering.

Jensen, A. W., Ephraim, Utah ; Forest Reserve Service. Johnson, L. E., Roanoke, Va., President Norfolk and Western Railway Company.

Jones, Hunt, Louisville, Ky.; State of Kentucky.

Jones, H. H., Washington, D. C.; General Land Office. Jones, William, Tacoma, Wash.; Chamber of Commerce.

Justus, T. W., Baltimore, Md.; Baltimore and Ohio Railroad.

Kalanianaole, Hon. Jonah K., Honolulu, Hawaii ; Territory of Hawaii.

Kaul, Jno. L., Birmingham, Ala.; Southern Lumber Manufacturers' Association.

Keen, Miss Florence, Philadelphia, Pa.; American Forestry Association.

Keller, O. B., New York city ; American Forestry Association from New York.

Kellogg, J. C., Louisiana; State of Louisiana.

Kellogg, R. S., Fay, Kan.; State of Kansas.

Kelsey, Frederick W., Orange, N. J.; American Forestry Association. 
Killen, Wm. H., Milwaukee, Wis.; Wisconsin Central Railway Company.

Kinney, David G., Washington, D. C. ; Bureau of Forestry.

Kittredge, G. W., Cincinnati, Ohio; Cleveland, Cincinnati, Chicago and St. Louis Railway Company.

Kneeper, David, Harrisburg, Pa.; Pennsylvania State Forestry Service.

Koch, Elers, Washington, D. C. ; American Forestry Association.

Lamb, Hon John, Richmond, Va.; State of Virginia. Langille, H. D., Santa Barbara, Cal.; Forest Reserve Service.

Langworthy, C. F., Washington, D. C.; American Forestry Association.

Lazenby, Wm. R., Columbus, Ohio; Ohio State Forestry Society.

Leland, J. D., Washington, D. C. ; General Land Office.

Lewis, W. H., Washington, D. C. ; General Land Office.

Lippincott, J. B., Washington, D. C. ; U. S. Geological Survey.

Little, Wm. T., Perry, Okla.; American Forestry Association from Oklahoma.

Loring, Hon. C. M., Minneapolis, Minn.; Minnesota Forestry Association.

Luebkert, Otto, Washington, D. C.; American Forestry Association.

McAllaster, Birdsall, Omaha, Neb.; Union Pacific Railway Company.

MacNaughton, James, New York city; American Society of Civic Engineers, New York Board of Trade and Transportation, and Association for Protection of the Adirondacks.

McBee, Silas, New York city; Delegate-at-large. 
McCann, John A., Philadelphia, Pa.; Editor National. Coopers' Journal.

McClure, R. C., Silver City, N. M.; Forest Reserve Service.

McCoy, Wilbur, New York city; Atlantic Coast Line Railroad Company.

McKeithan, D. T., South Carolina; State of South Carolina.

McKinney, J. M., Washington, D. C.; General Land Office.

McLeod, N. W., St. Louis, Mo.; Southern Lumber Manufacturers' Association.

Macbride, Thos. H., Iowa City, Iowa.; State of Iowa. McNeeley, E. J., Tacoma, Wash.; State of Washington.

McPhaul, John, Washington, D. C. ; General Land Office.

McVean, M. J., Washington, D. C.; General Land Office.

Macey, J. T., Washington, D. C. ; General Land Office. Maffet, Miss Martha A., Wilkesbarre, Pa.; American Forestry Association.

Maher, N. D., Roanoke, Va.; Norfolk and Western Railway.

Manderson, Gen. Chas. F., Chicago, Ill.; Chicago, Burlington and Quincy Railway Company.

Macoun, Prof. J. M., Canadian Geological Survey, Ottawa, Ontario, Canada.

Manning, W. H., Boston, Mass.; American Forestry Association.

Marr, S. S., General Land Office, Washington, D. C. Marston, Roy L., Yale Forest School, New Haven, Conn.

Mason, S. C., Berea, Ky.; State of Kentucky. Mast, Wm. H., Halsey, Neb.; State of Nebraska. 
Mather, William G., Cleveland, Ohio; Cleveland Chamber of Commerce.

Mathewson, Dr. Arthur, Woodstock, Conn. ; Connecticut Forestry Association.

Mattoon, W. R., Washington, D. C. ; American Forestry Association.

Maxwell, Geo. H., Chicago, I1l.; National Irrigation Association and State of California.

Mead, Elwood, Washington, D. C.; Department of Agriculture.

Meekham, H. S., Washington, D. C. ; American Forestry Association.

Merriam, Dr. C. Hart, Geological Survey, Washington, D. C. ; Sierra Club and American Forestry Association.

Merrill, H. G., American Forestry Association.

Merry, Capt. J. F., Dubuque, Iowa; Illinois Central Railroad Company.

Methudy, L., St: Louis, Mo.; National Lumber Exporters' Association.

Miller, Prof. Frank G., Lincoln, Neb.; University of Nebraska.

Miller, L. C., Washington, D. C.; Bureau of Forestry. Miller, W. H., Madison, Ind. ; Retail Lumber Dealers' Association.

Mitchell, Guy E., Washington, D. C.; American Forestry Association.

Moore, M. C., Milwaukee, Wis.; Editor Packages.

Mosle, M. A. ; Delegate-at-large.

Mulford, Walter, New Haven, Conn.; State of Connecticut.

Murphy, J. T., Washington, D. C. ; General Land Office.

Nelson, John M., Jr., Rider, Md.; State of Maryland. Newhall, D. S., Philadelphia, Pa.; Pennsylvania Railway Company. 
Newell, F. H., U. S. Geological Survey, Washington, D. C.

Norris, Jos. L., Leesburg, Va.; State of Virginia Oak, Hon. Chas. E., Bangor, Me.; State of Maine.

Olmsted, F. E., Washington, D. C. ; Bureau of Forestry.

Pack, Charles L., Lakewood, N. J.; Cleveland Chamber of Commerce.

Palmer, T. S., Washington, D. C. ; American Forestry Association.

Pammel, Prof. L. H., Secretary Iowa Park and Forestry Association, Ames, Iowa.

Parsons, Mrs. Henry, New York city; American Forestry Association.

Peavy, Geo. W., Washington, D. C. ; American Forestry Association.

Penrose, Dr. Chas. B., Philadelphia, Pa.; State of Pennsylvania.

Perry, E. F., New York city; National Wholesale Lumber Dealers' Association.

Peters, J. Girvin, Washington, D. C. ; American Forestry Association.

Peyton, Miss J. S., General Land Office, Washington, D. C.

Philbrick, S. W., Skowhegan, Me.; State of Maine.

Pinchot, Gifford, Bureau of Forestry, Washington, D. C. ; Bureau of Forestry, American Forestry Association, Sierra Club, Society American Foresters, Society American Civil Engineers.

Pinchot, James W., New York city; New York Chamber of Commerce.

Pollock, G. F., General Land Office, Washington, D. C. Pope, J. W., Atlanta, Ga.; State of Georgia.

Potter, A. F., Bureau of Forestry, Washington, D. C. Potter, H. G., General Land Office, Washington, D. C. 
Price, Overton W., Bureau of Forestry, Washington, D. C.

Purington, Pres. D. B., State University, Morgantown, W. Va.; State of West Virginia.

Putnam, H. C., Eau Claire, Wis. ; Lumbering.

Rane, Prof. F. Wm., Durham, N. H.; New Hampshire College, Boston and Maine Railroad, State of New Hampshire.

Reed, Franklin W., Washington, D. C. ; Society American Foresters.

Richards, J. T., Philadelphia, Pa.; Pennsylvania Railway Company.

Rinewalt, John M., Mt. Carroll, Ill.; Delegate-atlarge from Illinios.

Ring, Hon. Edgar E., Forest Commissioner, Augusta, Me.

Ross, D. M., Boise, Idaho; U. S. Geological Survey. Ross, Norman M., Ottawa, Canada; Dominion Forest Service.

Roth, Prof. Filibert, Ann Arbor, Mich. ; State of Michigan, University of Michigan.

Rothrock, J. T., Secretary State Forestry Reservation Commission, Harrisburg, $\mathrm{Pa}$.

Russell, I. C., Washington, D. C. ; National Geographic Society.

Russell, Jas. S., Boston, Mass.; Massachusetts Forestry Association.

Russell, F. B., Beer Stock Manufacturers' Association, Louisville, $\mathrm{Ky}$.

Satterlee, J. B., General Land Office, Washington, D. C.

Savage, H. N., U. S. Geological Survey, Washington, D. C.

Scaife, Marvin F., Pittsburg, Pa.; Pennsylvania State Forestry Association. 
Schaperkotter, Jas. F., Philadelphia, Pa. ; Lehigh Valley Railroad system.

Schenck, Dr. C. A., Biltmore, N. C.; Biltmore Forestry School.

Schwarz, G. Fred, New York city; American Forestry Association from New York city.

Scott, Chas. A., Halsey, Neb.; State of Nebraska. Sebastian, Jon., Chicago, I1l.; Rock Island Railway system.

See, Mrs. Horace, New York city ; American Forestry Association.

Seeley, J. B., Virginia City, Mont.; Forest Reserve Service.

Shaw, A. C., General Land Office, Washington, D. C. Shaw, Eugene, Wisconsin Hardwood Lumbermen's Association, Eau Claire, Wis.; Mississippi Valley Lumber Association.

Sheller, D. B., Tacoma, Wash.; Washington Forest Reserve Service.

Sherfesse, W. F., Charleston, S. C.; State of South Carolina.

Shepardson, H. L., Baldwinville, Mass. ; National Association of Box and Box Shook Manufacturers of United States.

Sherman, W. F., General Land Office, Washington, D. C.

Sherrard, Thos. H., Bureau of Forestry, Washington, D. C.

Shields, G. O., Editor and Manager Recreation;

League of American Sportsmen, Delegate-at-large. Shoemaker, Samuel M., Stevenson, Md.; State of Maryland.

Silcox, F. E., Charleston, S. C. ; State of South Carolina.

Silvester, Pres. R. W., Maryland Agricultural College, 
College Park, Md.; American Forestry Association from Maryland.

Smith, G. O., U. S. Geological Survey, Washington, D. C.

Smith, H. A., Bureau of Forestry, Washington, D. C. Smith, Geo. K., Secretary Southern Lumber Manufacturers' Association, St. Louis, Mo.; Southern Lumber Manufacturers' Association, National Lumber Manufacturers' Association, Western Pine Shippers' Association.

Snyder, J. M., Bay City, Mich.; American Forestry Association.

Spring, Preston B., Easton, Md.; State of Maryland. Spring, Prof. Samuel N., Orono, Me.; University of Maine.

Start, Edwin A., Boston, Mass.; Massachusetts Forestry Association.

Steele, Henry M., Macon, Ga. ; Central Georgia Railway Company.

Sterling, E. A., Bureau of Forestry, Washington, D. C. Sheller, R. H., Tacoma, Wash.; Forest Reserve Service.

Stewart, Elihu, Forestry Branch, Department of Interior, Ottawa, Ontario; Canadian Forestry Association.

Stewart, Frank, Prescott, Ariz.; Territory of Arizona. Strong, C. B., General Land Office, Washington, D. C. Stont, J. H., Menomonee, Wis.; State of Wisconsin. Strong, Miss L. M., General Land Office, Washington, D. C.

Sudworth, Geo. B., Bureau of Forestry, Washington, D. C.

Suter, H. M., Washington, D. C.; Editor Forestry and Irrigation.

Tennille, A. F., Washington, D. C.; The American Lumberman. 
Thayer, Hon. Samuel R., Minneapolis, Minn.; Minnesota State Forestry Association.

Thomas, E. B., Los Angeles, Cal.; Forest Reserve Service.

Tompkins, H. J., Washington, D. C. ; Bureau of Forestry.

Totten, Mrs. S. G., Washington, D. C.; General Land Office.

Toumey, Prof. J. W., New Haven, Conn.; Yale Forest School.

Tower, G. E., Washington, D. C.; American Forestry Association.

Tremaine, Morris, Buffalo, N. Y.; National Wholesale Lumber Dealers' Association.

Underwood, Geo. F., New York city; Water Storage and Manufacturing Association.

Von Schrenk, Dr. Hermann, Washington, D. C. ; Burean of Forestry.

Van Aiken, C. M., New York city; National Slack Cooperage Association. .

Vreeland, Robert, Frankfort, Ky.; State of Kentucky. Wadsworth, W. A., Genesee, N. Y.; State of New York.

Waite, Mrs. C. V., Roggen, Colo.; State of Colorado. Walcott, Dr. Chas. D., Washington, D. C. ; U. S. Geological Survey.

Walker, F. B., Washington, D. C. ; General Land Office.

Walsh, Thos. F., Washington, D. C.; Denver Chamber of Commerce.

Wantland, C. E., Denver, Colo.; State of Colorado. Ware, Miss Mary Lee, Boston, Mass.; Massachusetts Forestry Association.

Webster, Jr., N. E., Washington, D. C. ; U. S. Reclamation Service. 
Weed, W. H!, Washington, D. C.; U. S. Geological Survey.

Wells, Geo. T., Drifton, Pa.; American Forestry Association from Pennsylvania.

Weyerhaeuser, Jr., Fred E., St. Paul, Minn.; Weyerhaeuser Lumber Company and Mississippi Valley Lumberman's Association.

Wheeler, Mrs. C. H., Boston, Mass. ; American Forestry Association.

White, J. B., Kansas City, Mo.; Southern Lumber Manufacturers' Association.

White, J. W., Portsmouth, Va.; Seaboard Air Line Railway.

Whittlesey, Geo. P., Washington, D. C.; American Forestry Association.

White, Aubrey, Toronto, Canada; Canada.

White, H. D., Enid, Okla.; Territory of Oklahoma.

White, W. H., Warren City, Mich.; Hardwood Manufacturers' Association.

White, T. Brook, Portland, Ore. ; State of Oregon.

Wiggins, Vice-Chancellor B. L., Sewanee, Tenn.; University of the South.

Williams, A. S., Berlin, N. H. ; Berlin Mills Company. Williams, F. B., Patterson, La.; National Lumber Manufacturers' Association.

Williams, Irvin C., Harrisburg, Pa. ; Forestry Academy and Pennsylvania Forestry Association.

Williams, Mrs. L. P., Minneapolis, Minn.; State of Minnesota.

Williams, Hon. M. M., Little Falls, Minn.; State of Minnesota.

Wilms, William, Chicago, Ill.; Hardwood Manufacturers' Association.

Wilson, H. M., Washington, D. C.; U. S. Geological Survey and American Society of Civil Engineers. 
Winchester, A. H., New Orleans, La.; Lumber Trade Journal.

Winchester, Col. A. H., Buckhannon, W. Va.; State of West Virginia.

Wirt, Geo. H., Harrisburg, Pa.; Forestry Academy and Pennsylvania Forestry Association.

Witten, J. W., Washington, D. C.; General Land Office.

Wood, Richard, Philadelphia, Pa.; Pennsylvania Forestry Association.

Woodruff, Geo. W., Washington, D. C.; Bureau of Forestry.

Worden, F. E., Oshkosh, Wis.; Northwestern Hemlock Manufacturers' Association.

Ziegler, E. A., Washington, D. C., Saline Valley Teleprone Company. 


\section{THE AMERICAN FORESTRY ASSOCIA- TION}

President, HON. JAMES WILSON

Secretary of Agriculture

The American Forestry Association was organized in I882, and incorporated in January, I897. It now has nearly three thousand members, residents of every State in the Union, Canada, and foreign countries. It has at all times been active in promoting measures tending toward the proper utilization of the forests and their protection from destruction by fires and wasteful use.

The objects of this Association are to promote:

I. A business-like and conservative use and treatment of the forest resources of this country;

2. The advancement of legislation tending to this end, both in the States and the Congress of the United States, the inauguration of forest administration by the Federal Government and by the States; and the extension of sound forestry by all proper methods ;

3. The diffusion of knowledge regarding the conservation, management, and renewal of forests, the proper utilization of their products, methods of reforestation of waste lands, and the planting of trees.

The Association desires and needs as members all who are interested in promoting the objects for which it is organized-all who realize the importance of using the national resources of the country in such a man- 
ner as not to exhaust them, or to work ruin to other interests. In particular it appeals to owners of woodlands, to lumbermen and foresters, as well as to engineers, professional, and business men who have to do with wood and its manifold uses, and to persons concerned in the conservation of water supplies for irrigation or other purposes.

The American Forestry Association holds annual and special meetings at different places in the country for the discussion and exchange of ideas, and to stimulate interest in its objects. Forestry and Irrigation, the magazine of authority in its special field, is the official organ of the Association, and is sent free to every member monthly. Its list of contributors includes practically all persons prominent in forest work in the United States, making it alone worth the cost of annual membership in the Association.

The annual dues are, for regular members, $\$ 2.00$, for sustaining members, $\$ 25.00$; life membership is $\$ 100$, with no further dues. Any person contributing $\$ I, 000$ to the funds of the Association shall be a Patron.

H. M. SUTER, Secretary. Address: P. O. Box 356, Washington, D. C. 





